\author{
UNIVERSIDADE DE SÃO PAULO \\ FACULDADE DE CIÊNCIAS FARMACÊUTICAS DE RIBEIRÃO PRETO
}

Estudos sobre o metabolismo microbiano de naftoquinonas e avaliação da citotoxicidade dos metabólitos obtidos

Eliane de Oliveira Silva

Ribeirão Preto 


\author{
UNIVERSIDADE DE SÃO PAULO \\ FACULDADE DE CIÊNCIAS FARMACÊUTICAS DE RIBEIRÃO PRETO
}

\title{
Estudos sobre o metabolismo microbiano de naftoquinonas e avaliação da citotoxicidade dos metabólitos obtidos
}
Tese de Doutorado apresentada ao Programa de Pós-Graduação em Ciências Farmacêuticas para obtenção do Título de Doutor em Ciências.

Área de Concentração: Produtos Naturais e Sintéticos.

Orientada: Eliane de Oliveira Silva Orientadora: Profa. Dra. Niege Araçari Jacometti Cardoso Furtado

\begin{abstract}
Versão corrigida da Tese de Doutorado apresentada ao Programa de PósGraduação em Ciências Farmacêuticas em 07/02/2014. A versão original encontra-se disponível na Faculdade de Ciências Farmacêuticas de Ribeirão Preto/USP.
\end{abstract}

Ribeirão Preto 
AUTORIZO A REPRODUÇÃO E DIVULGAÇÃO TOTAL OU PARCIAL DESTE TRABALHO, POR QUALQUER MEIO CONVENCIONAL OU ELETRÔNICO, PARA FINS DE ESTUDO E PESQUISA, DESDE QUE CITADA A FONTE.

FICHA CATALOGRÁFICA

Silva, Eliane de Oliveira.

Estudos sobre o metabolismo microbiano de naftoquinonas e avaliação da citotoxicidade dos metabólitos obtidos. Ribeirão Preto, 2014.

187 p. : il. ; $30 \mathrm{~cm}$.

Tese de Doutorado, apresentada à Faculdade de Ciências Farmacêuticas de Ribeirão Preto/USP - Área de concentração: Produtos Naturais e Sintéticos.

Orientadora: Furtado, Niege Araçari Jacometti Cardoso.

1. Naftoquinonas. 2. Biotransformação. 3. Citotoxicidade. 


\section{FOLHA DE APROVAÇÃO}

Autora: Eliane de Oliveira Silva

Título do trabalho: Estudos sobre o metabolismo microbiano de naftoquinonas e avaliação da citotoxicidade dos metabólitos obtidos

Tese de Doutorado apresentada ao

Programa de Pós-Graduação em Ciências

Farmacêuticas para obtenção do Título de

Doutor em Ciências.

Área de Concentração: Produtos Naturais e Sintéticos.

Orientadora: Profa. Dra. Niege Araçari Jacometti Cardoso Furtado

Aprovado em:

Banca Examinadora

Prof. Dr.

Instituição:

Assinatura:

Prof. Dr.

Instituição:

Assinatura:

Prof. Dr.

Instituição:

Assinatura:

Prof. Dr.

Instituição:

Assinatura:

Prof. Dr.

Instituição: Assinatura: 
Dedico este trabalho,

Aos meus pais, Ademir e Arlete, e à minha irmã Elisa por sempre apoiarem meus sonhos;

Ao meu querido namorado Thiago pelo apoio, companheirismo e paciência;

À Profa. Dra. Niege Araçari Jacometti Cardoso Furtado pela orientação. 
A Deus, por me guiar;

Aos Profs. da Faculdade de Ciências da Universidade de Cádiz (Espanha), Dr. Isidro González Collado e Dra. Josefina Aleu, pela orientação durante a realização do estágio de doutorado sanduíche;

Ao Prof. Dr. Flávio da Silva Emery pela constante ajuda com as quinonas;

Ao grupo da Profa. Dra. Raquel dos Santos, da Universidade de Franca, pela realização dos ensaios de citotoxicidade;

Ao Prof. Dr. Antônio Gilberto Ferreira, do Departamento de Química da Universidade Federal de São Carlos, pela obtenção dos espectros de Ressonância Magnética Nuclear;

Aos técnicos de laboratório que contribuíram para a realização deste trabalho, especialmente Angélica, Vinícius, Thomaz, Júnior, Áurea e Mário;

Aos amigos do laboratório de Farmacognosia, especialmente Tatiane Cruz de Carvalho; 
À Coordenação do programa de pós-graduação em Ciências Farmacêuticas da Faculdade de Ciências Farmacêuticas de Ribeirão Preto da Universidade de São Paulo;

À Faculdade de Ciências Farmacêuticas de Ribeirão Preto, local de desenvolvimento deste trabalho;

Aos demais professores das disciplinas que cursei;

À CAPES, à Fapesp e ao CNPq pelo apoio financeiro. 
"De certo ponto adiante não há mais retorno. Esse é o ponto que deve ser alcançado.”

(Franz Kafka) 
SUMÁRIO

RESUMO

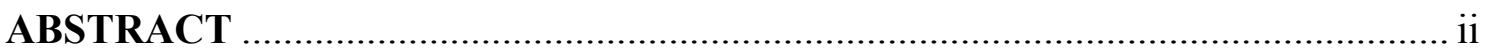

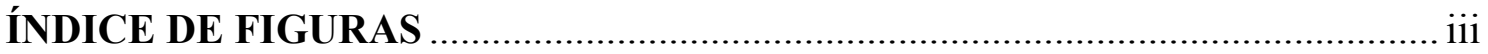

ÍNDICE DE TABELAS ............................................................................ vii

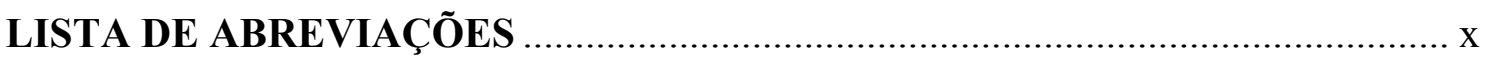

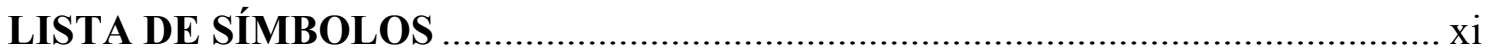

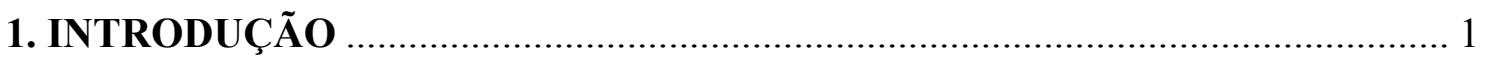

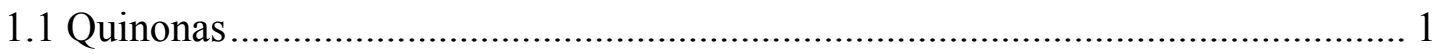

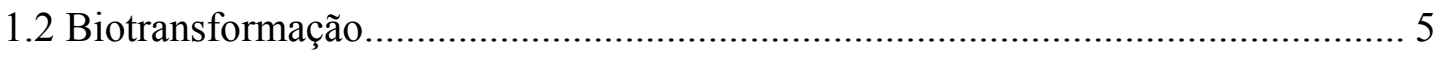

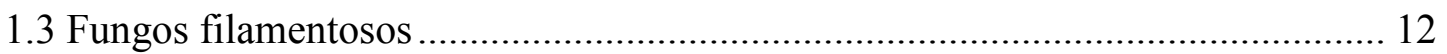

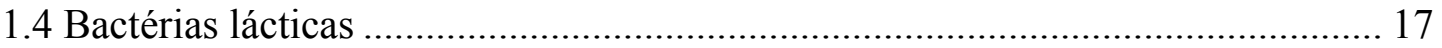

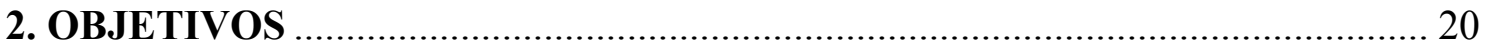

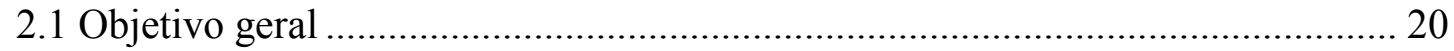

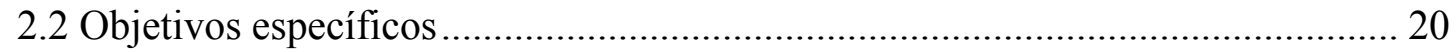

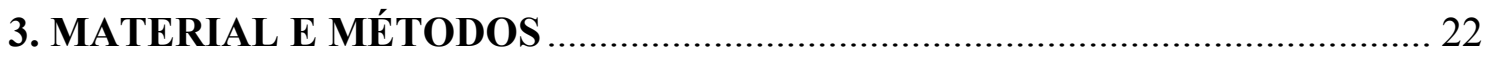

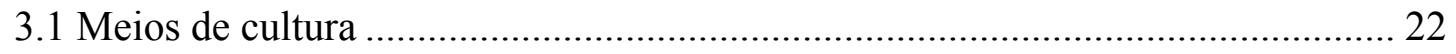

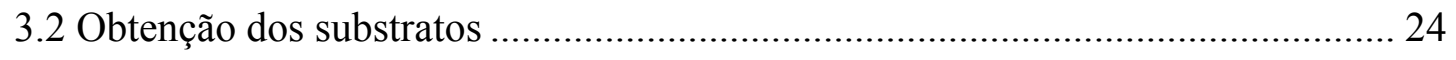

3.2.1 Obtenção do lapachol e atovaquona ....................................................... 24

3.2.2 Obtenção do sal de potássio do lapachol .................................................... 24

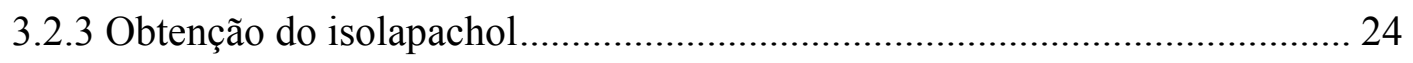

3.3 Micro-organismos utilizados nos processos de biotransformação ........................ 25 
3.4 Manutenção dos fungos filamentosos e das bactérias do trato gastrointestinal ... 26

3.5 Produção de esporos e padronização do crescimento dos fungos filamentosos... 26

3.6 Padronização do crescimento das bactérias do trato gastrointestinal ..... 27

3.7 Verificação dos efeitos tóxicos dos substratos sobre os micro-organismos utilizados.

3.8 Avaliação da influência das condições de cultivo nas reações de biotransformação do lapachol e do seu sal de potássio com fungos filamentosos

3.9 Avaliação da influência das condições de cultivo nas reações de biotransformação do lapachol e do seu sal de potássio com bactérias do trato gastrointestinal 34

3.10 Avaliação da influência das condições de cultivo nas reações de biotransformação do isolapachol e da atovaquona com fungos filamentosos e bactérias do trato gastrointestinal 35

3.11 Obtenção das frações dos caldos das culturas dos fungos e bactérias e dos micélios das culturas dos fungos 35

3.12 Avaliação dos perfis químicos das frações obtidas das culturas dos fungos filamentosos e das bactérias gastrointestinais 36

3.13 Biotransformação do lapachol e atovaquona em escala preparativa 37

3.14 Isolamento dos produtos de biotransformação 37

3.15 Identificação estrutural dos metabólitos isolados 38

3.16 Ensaios citotóxicos 39

\section{RESULTADOS E DISCUSSÕES}

4.1 Substratos utilizados nas reações de biotransformação 41

4.2 Padronização do crescimento dos micro-organismos utilizados nas biotransformações. 46

4.3 Verificação dos efeitos tóxicos dos substratos sobre os micro-organismos utilizados nas biotransformações 49

4.4 Estudos sobre a biotransformação do lapachol e do seu sal de potássio por fungos filamentosos de diferentes gêneros 50 
4.5 Estudos sobre a biotransformação do lapachol por fungos filamentosos do gênero Cunninghamella 55

4.6 Estudos sobre a biotransformação do lapachol por diferentes linhagens de Botrytis cinerea e Mucor circinelloides..... 57

4.7 Estudos sobre a biotransformação do lapachol e do seu sal de potássio por bactérias do trato gastrointestinal 61

4.8 Ampliação da escala dos cultivos e isolamento dos metabólitos 64

4.9 Identificação estrutural dos metabólitos do lapachol 66

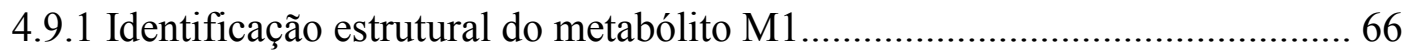

4.9.2 Identificação estrutural do metabólito M2 ................................................... 71

4.9.3 Identificação estrutural do metabólito M3 ................................................ 73

4.9.4 Identificação estrutural do metabólito M4 ............................................... 75

4.9.5 Identificação estrutural do metabólito M5 .................................................. 78

4.10 Estudos acerca da produção do metabólito M1 a partir da biotransformação do lapachol por A. brasiliensis 80

4.10.1 Identificação estrutural do metabólito M6. 82

4.10.2 Identificação estrutural do metabólito M7. 84

4.10.3 Estudos sobre a cinética de formação de M6 86

4.11 Avaliação da citotoxicidade dos metabólitos do lapachol obtidos por biotransformação 90

4.12 Estudos sobre a biotransformação da atovaquona por fungos filamentosos e bactérias do trato gastrointestinal 93

4.12.1 Isolamento do metabólito da atovaquona 97

4.12.2 Identificação estrutural do metabólito M8. 97

4.12.3 Avaliação da citotoxicidade do metabólito obtido a partir da biotransformação da atovaquona..... 99

4.13 Estudos sobre a biotransformação do isolapachol por fungos filamentosos e bactérias do trato gastrointestinal 100 
5. CONCLUSÕES.

6. REFERÊNCIAS BIBLIOGRÁFICAS

APÊNDICES . 


\section{RESUMO}

SILVA, E. O. Estudos sobre o metabolismo microbiano de naftoquinonas e avaliação da citotoxicidade dos metabólitos obtidos. 2014. 187f. Tese (Doutorado). Faculdade de Ciências Farmacêuticas de Ribeirão Preto - Universidade de São Paulo, Ribeirão Preto, 2014.

Muitas naftoquinonas como o lapachol, podem ser encontradas em plantas da família Bignoniaceae e são conhecidas por desempenharem diversas atividades biológicas, acompanhadas, entretanto, por efeitos indesejáveis. A atividade citotóxica apresentada pelas naftoquinonas está relacionada ao aparecimento de espécies reativas de oxigênio in vivo que causam severo estresse oxidativo no interior das células. $\mathrm{O}$ isolapachol e a atovaquona são análogos estruturais do lapachol, sendo que a atovaquona é comercializada como fármaco para o tratamento de malária e certos tipos de pneumonia. Devido ao grande potencial biológico apresentado pelas naftoquinonas, várias tentativas no sentido de obtenção de derivados desprovidos de efeitos colaterais vêm sendo realizadas. Além disso, a determinação da segurança e eficácia dos fármacos está intimamente ligada ao estudo da formação de derivados in vivo por ocasião do metabolismo. A utilização de fungos filamentosos na predição do metabolismo que os fármacos sofreriam após administração oral, bem como de bactérias do trato gastrointestinal, pode contribuir substancialmente para a elucidação da rota metabólica de fármacos fornecendo informações sobre a geração de substâncias farmacologicamente ativas, inativas ou tóxicas e ainda sobre a produção de substâncias capazes de inibir a biotransformação de outros fármacos. Estudos de biotransformação também podem contribuir para a obtenção de novos esqueletos químicos. Dessa forma, o presente trabalho relata estudos do metabolismo microbiano do lapachol e do seu sal de potássio por bactérias do trato gastrointestinal e fungos filamentosos, além da correlação desses com as reações que ocorrem quando o isolapachol e a atovaquona são utilizados como substratos para os mesmos micro-organismos. Os experimentos de biotransformação utilizando lapachol e seu sal de potássio foram conduzidos por até dez dias, em diferentes meios de cultura, empregando-se quatro linhagens de bactérias presentes no trato gastrointestinal, além de 11 linhagens de fungos filamentosos. Foram obtidos sete metabólitos, sendo dois inéditos e dois anteriormente detectados em estudos sobre o metabolismo do lapachol em mamíferos. Durante a realização dos experimentos com o fungo filamentoso Aspergillus brasiliensis verificou-se a capacidade desse fungo em mimetizar uma reação muito importante em química orgânica, conhecida como oxidação de Hooker. As condições mais promissoras para a biotransformação do lapachol foram utilizadas nos estudos com a atovaquona e o isolapachol. A biotransformação da atovaquona possibilitou, pela primeira vez, a caracterização estrutural de um metabólito desse fármaco. Já os estudos realizados com o isolapachol permitiram inferências sobre a especificidade enzimática apresentada pelos micro-organismos avaliados. Todos os metabólitos obtidos foram submetidos aos ensaios de citotoxicidade frente a linhagens celulares normais e tumorais, o que possibilitou obter conclusões sobre a relação estrutura-atividade e sobre a citotoxicidade seletiva apresentada pelos metabólitos. Destaca-se o resultado obtido com um dos metabólitos do lapachol, $\alpha$-xiloidona, o qual se mostrou mais tóxico para a linhagem tumoral que o lapachol e não apresentou toxicidade frente à linhagem normal. $O$ metabólito obtido a partir da biotransformação da atovaquona apresentou maior toxicidade não seletiva que a substância de partida.

Palavras-chave: Naftoquinona, Biotransformação, Citotoxicidade. 


\begin{abstract}
SILVA, E. O. Microbial metabolism studies of naphthoquinones and cytotoxicity evaluation of the obtained metabolites. 2014. 187f. PhD tesis. Faculdade de Ciências Farmacêuticas de Ribeirão Preto - Universidade de São Paulo, Ribeirão Preto, 2014.

Several naphthoquinones, as lapachol, can be found in the Bignoniaceae family and they present several biological activities with some unwanted effects. The cytotoxic activity displayed by naphthoquinones is correlated to the presence of reactive oxygen species, which are formed in vivo and cause severe oxidative stress within cells. Isolapachol and atovaquone are structural analogs of lapachol, and atovaquone is in the market as a drug for the treatment of malaria and some types of pneumonia. Because of the great biological potential presented by naphthoquinones, several studies have been carried out to obtain derivatives without side effects. Furthermore, the drug safety and efficacy are closely related to the study of the formation of in vivo derivatives during metabolism. The filamentous fungi and the bacteria from the gastrointestinal tract can be used in the prediction of drug metabolism after oral administration, which is an interesting tool to elucidation of the metabolic pathway of drugs, providing information on the generation of pharmacologically active, inactive or toxic substances and still on the production of compounds able to inhibit the biotransformation of other drugs. Biotransformation studies can also contribute to the obtention of new chemical skeletons (hits). Thus, the present work reports the study about the microbial metabolism of lapachol and its potassium salt by filamentous fungi and bacteria from the gastrointestinal tract, beyond the correlation of the reactions that occur when the isolapachol and atovaquone are used as substrates for the same microorganisms. The biotransformations of lapachol and its potassium salt were evaluated for up to ten days, in different culture media, catalyzed by four bacteria from the gastrointestinal tract and 11 filamentous fungi strains. Seven metabolites were obtained, from which two are new and two were previously detected in the mammals metabolism of lapachol. The filamentous fungus Aspergillus brasiliensis showed to be capable of mimicking the Hooker oxidation, an important organic chemistry reaction. The best conditions for the lapachol biotransformation have been used in the studies with isolapachol and atovaquone. The atovaquone biotransformation provided, for the first time, the structural characterization of a metabolite from this drug. The studies with isolapachol allowed inferences about the enzyme specificity shown by the evaluated microorganisms. All obtained metabolites were submitted to cytotoxicity assays against human cancer and tumoral cell lines. Several conclusions about the structure activity relationship and about the selective cytotoxicity showed by the metabolites were taken. It should be highlighted the obtained result with a lapachol metabolite, $\alpha$-xyloidone, which showed to be more toxic than lapachol against tumoral cell line and did not show cytotoxicity to normal cell line. The atovaquone metabolite displayed higher toxicity than pattern structure, and this activity was not selective.
\end{abstract}

Key words: Naphthoquinone, Biotransformation, Cytotoxicity 


\section{ÍNDICE DE FIGURAS}

Figura 1. Classificação química das quinonas. 1

Figura 2. Estrutura química dos fármacos quimioterápicos detentores de anel quinona. 1

Figura 3. Formação de semiquinona após análogo da $\beta$-lapachona ter sido irradiado na presença de doador de hidrogênio (Fonte: NETTO-FERREIRA et al., 2010)................. 2

Figura 4. Semelhanças estruturais existentes entre lapachol e vitamina K. .................... 3

Figura 5. Estruturas químicas do lapachol (1), atovaquona (2) e isolapachol (3).......... 5

Figura 6. Exemplos de fármacos inibidores da ECA provenientes da Lhomofenilalanina (Fonte: AHMAD, OH e SHUKOR, 2009)...................................... 9

Figura 7. Biotransformação da naftoquinona INO5042 por duas linhagens de Streptomyces (Fonte: FOSSE et al., 2004). 10

Figura 8. Biotransformação da chiconina por Bacteroides fragilis subsp. thetaotus (Fonte: MESELHY et al., 1994). 10

Figura 9. Diferentes fármacos empregados nas biotransformações catalisadas por Mucor sp...... 15

Figura 10. Transformação de ácido ent-pimaradienóico (1) em metil $7 \alpha$-hidroxi entpimara-8(14),15-dien-19-oato (2) por A. niger (Fonte: SEVERIANO et al., 2013)...... 16 Figura 11. Estrutura química, nome químico, fórmula molecular, massa molecular exata, tempo de retenção em CLAE-DAD e algumas propriedades físico-químicas do lapachol.

Figura 12. Cromatograma do lapachol (A), tempo de retenção 23,45 minutos, e seu espectro de absorção no ultravioleta (B).

Figura 13. Estrutura química, nome químico, fórmula molecular, massa molecular exata, tempo de retenção em CLAE-DAD e algumas propriedades físico-químicas do isolapachol.

Figura 14. Cromatograma do isolapachol (A), tempo de retenção 26,13 minutos, e seu espectro de absorção no ultravioleta (B).

Figura 15. Estrutura química, nome químico, fórmula molecular, massa molecular exata, tempo de retenção em CLAE-DAD e algumas propriedades físico-químicas da atovaquona.

Figura 16. Cromatograma da atovaquona (A), tempo de retenção 32,83 minutos, e seu espectro de absorção no ultravioleta (B). 45

Figura 17. Curva de crescimento das bactérias intestinais. 48 
Figura 18. Cromatogramas das frações em acetato de etila dos cultivos de $A$. brasiliensis com (A) e sem lapachol (B).

Figura 19. Cromatogramas das frações em acetato de etila dos cultivos de $M$. rouxii com (A) e sem lapachol (B)

Figura 20. Cromatogramas das frações em acetato de etila dos cultivos de A. ochraceus com (A) e sem lapachol (B).

Figura 21. Cromatogramas das frações em acetato de etila dos cultivos de $R$. stolonifer com (A) e sem lapachol (B) 53

Figura 22. Cromatogramas das frações em acetato de etila dos cultivos de C. lunata com (A) e sem lapachol (B)

Figura 23. Espectro no ultravioleta dos metabólitos majoritários produzidos a partir da biotransformação do lapachol por: (A) A. brasiliensis e M. rouxii, (B) A. ochraceus, $R$. stolonifer e C. lunata 54

Figura 24. Cromatogramas das frações em acetato de etila dos cultivos de C. echinulata var. elegans com (A) e sem lapachol (B). 56

Figura 25. Cromatogramas das frações em acetato de etila dos cultivos de C. elegans com (A) e sem lapachol (B) 56

Figura 26. Espectro no ultravioleta do metabólito majoritário produzido por C. echinulata var. elegans e C. elegans. 57

Figura 27. Cromatogramas das frações em acetato de etila dos cultivos de $B$. cinerea UCA992 com (A) e sem lapachol (B). 58

Figura 28. Cromatogramas das frações em acetato de etila dos cultivos de $B$. cinerea 2100 com (A) e sem lapachol (B).

Figura 29. Espectro no ultravioleta do metabólito majoritário produzido por duas linhagens de $B$. cinerea (UCA992 e 2100). 59

Figura 30. Cromatogramas das frações em acetato de etila dos cultivos de M. circinelloides (+) com (A) e sem lapachol (B). 60

Figura 31. Cromatogramas das frações em acetato de etila dos cultivos de M. circinelloides (-) com (A) e sem lapachol (B). 60

Figura 32. Cromatogramas das frações em acetato de etila dos cultivos de M. circinelloides (+) e (-), em cultura mista, com (A) e sem lapachol (B). 60

Figura 33. Espectro de absorção no ultravioleta do metabólito majoritário obtido nos cultivos com as duas linhagens de M. circinelloides em culturas isoladas e mistas 61 
Figura 34. Cromatogramas das frações em acetato de etila dos cultivos de $L$. acidophilus com (A) e sem lapachol (B).

Figura 35. Cromatogramas das frações em acetato de etila dos cultivos de Bifidobacterium sp. com (A) e sem lapachol (B).

Figura 36. Cromatogramas das frações em acetato de etila dos cultivos de Bifidobacterium sp. e L. acidophilus em cultura mista com S. salivarius subsp. thermophilus com (A) e sem lapachol (B).

Figura 37. Espectro no ultravioleta dos metabólitos majoritários produzidos a partir da biotransformação do lapachol por: (A) Bifidobacterium sp. e L. acidophilus em cultura mista com S. salivarius subsp. thermophilus;(B) Bifidobacterium sp. e L. acidophilus em culturas isoladas.

Figura 38. Cromatogramas das frações em acetato de etila dos cultivos de E. coli com (A) e sem lapachol (B). 64

Figura 39. Estrutura química do metabólito M1. 67

Figura 40. Correlações ${ }^{1} \mathrm{H}^{-13} \mathrm{C}$ do metabólito M1 68

Figura 41. Formação de nor-lapachol (1b) a partir de lapachol (1) - oxidação de Hooker.

Figura 42. Participação do intermediário de Hooker (1a) na transformação de lapachol (1) em nor-lapachol (1b) 70

Figura 43. Éter tricíclico obtido a partir do intermediário de Hooker (1a) por Eyong et al. (2013) 71

Figura 44. Estrutura química do metabólito M2. 71

Figura 45. Estrutura química do metabólito M3. 73

Figura 46. Deslocamentos químicos (ppm) dos ${ }^{13} \mathrm{C}$ dos isômeros $E$ e $Z$ do 2-metil-2buten-1-ol e do lomatiol implicados na determinação da configuração relativa............. 75

Figura 47. Estrutura química do metabólito M4 ..................................................... 76

Figura 48. Estrutura química do metabólito M5 ....................................................... 78

Figura 49. Formação do intermediário de Hooker (1a) e nor-lapachol (1b) durante a oxidação de Hooker do lapachol (1). 81

Figura 50. Perfil cromatográfico da fração em acetato de etila dos metabólitos produzidos por $A$. brasiliensis, em meio Koch's K1 modificado 82

Figura 51. Estrutura química do metabólito M6. 83

Figura 52. Estrutura química do metabólito M7. 84 
Figura 53. Produção de M7 a partir do lapachol (1), passando pelo intermediário de Hooker (1a). 86

Figura 54. Cromatogramas das frações em acetato de etila de diferentes alíquotas da biotransformação do lapachol (1) por A. brasiliensis em M6 e M7. A: 2 horas de cultivo; B: 4 horas de cultivo; C: 6 horas de cultivo; D: 12 horas de cultivo; E: 18 horas de cultivo; F: 24 horas de cultivo.

Figura 55. Produção de M6 e desaparecimento de M7 do meio de cultura onde o lapachol foi biotransformado por A. brasiliensis. 88

Figura 56. Produção de M6 e M7 a partir da biotransformação do lapachol (1) por $A$. brasiliensis, tendo 1a (intermediário de Hooker) como intermediário.

Figura 57. Metabólitos obtidos nos processos de biotransformação do lapachol por diferentes fungos filamentosos e bactérias do trato gastrointestinal. 91

Figura 58. Cromatogramas das frações em acetato de etila dos cultivos de $A$. brasiliensis com (A) e sem atovaquona (B). 95

Figura 59. Cromatogramas das frações em acetato de etila dos cultivos de $M$. rouxii com (A) e sem atovaquona (B). 95

Figura 60. Cromatogramas das frações em acetato de etila dos cultivos de C. elegans com (A) e sem atovaquona (B).

Figura 61. Cromatogramas das frações em acetato de etila dos cultivos de C. echinulata var. elegans com (A) e sem atovaquona (B). 95

Figura 62. Cromatogramas das frações em acetato de etila dos cultivos de Bifidobacterium sp. com (A) e sem atovaquona (B). 96

Figura 63. Cromatogramas das frações em acetato de etila dos cultivos de $L$. acidophilus com (A) e sem atovaquona (B). 96

Figura 64. Cromatogramas das frações em acetato de etila dos cultivos da cultura mista

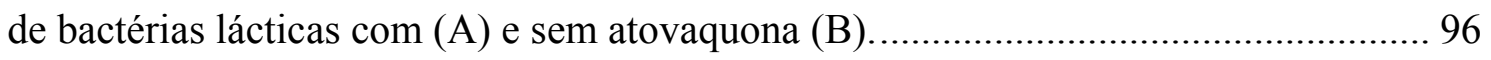

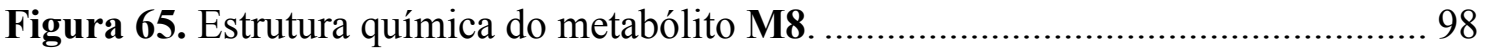

Figura 66. Produção do metabólito M8 a partir da atovaquona.................................. 100

Figura 67. Cromatogramas das frações em acetato de etila dos cultivos de $A$. brasiliensis com (A) e sem isolapachol (B).

Figura 68. Cromatogramas das frações em acetato de etila dos cultivos de $M$. rouxii com (A) e sem isolapachol (B).

Figura 69. Cromatogramas das frações em acetato de etila dos cultivos de C. elegans com (A) e sem isolapachol (B). 102 
Figura 70. Cromatogramas das frações em acetato de etila dos cultivos de C. echinulata var. elegans com (A) e sem isolapachol (B) 102

Figura 71. Cromatogramas das frações em acetato de etila dos cultivos da mistura de bactérias lácticas com (A) e sem isolapachol (B) 104

Figura 72. Cromatogramas das frações em acetato de etila dos cultivos com $L$. acidophilus com (A) e sem isolapachol (B). 104

Figura 73. Cromatogramas das frações em acetato de etila dos cultivos com Bifidobacterium sp. com (A) e sem isolapachol (B). 105 


\section{ÍNDICE DE TABELAS}

Tabela 1. Comparação entre os metabólitos de mamíferos com os microbianos de alguns produtos naturais (Fonte: VENISETTY e CIDDI, 2003). 11

Tabela 2. Dados de $\mathrm{RMN}$ de ${ }^{1} \mathrm{H}(500 \mathrm{MHz})$ e ${ }^{13} \mathrm{C}(125 \mathrm{MHz})$, em $\mathrm{CDOD}_{3}$ do lapachol,

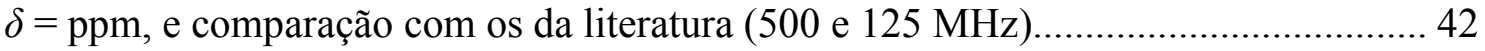
Tabela 3. Dados de $\mathrm{RMN}$ de ${ }^{1} \mathrm{H}(500 \mathrm{MHz})$ e ${ }^{13} \mathrm{C}(125 \mathrm{MHz})$, em $\mathrm{CDCl}_{3}$ do isolapachol, $\delta=\mathrm{ppm}$ 44

Tabela 4. Dados de $\mathrm{RMN}$ de ${ }^{1} \mathrm{H}(500 \mathrm{MHz})$ e ${ }^{13} \mathrm{C}(125 \mathrm{MHz})$, em $\mathrm{CDCl}_{3}$ da atovaquona, $\delta=\mathrm{ppm}$.

Tabela 5. Tempo que cada micro-organismo necessitou para adentrar a fase estacionária de crescimento.

Tabela 6. Tempo que cada bactéria intestinal necessitou para adentrar a fase estacionária de crescimento 48

Tabela 7. Metabólitos produzidos nos processos de biotransformação do lapachol por diferentes micro-organismos.

Tabela 8. Rendimentos dos metabólitos do lapachol obtidos a partir das biotransformações. 66

Tabela 9. Sinais de $\mathrm{RMN}$ de ${ }^{1} \mathrm{H}(500 \mathrm{MHz}),{ }^{13} \mathrm{C}(125 \mathrm{MHz})$ e HMBC do metabólito $\mathrm{M1}$ em $\mathrm{CD}_{3} \mathrm{OD}, \delta$ em ppm 68

Tabela 10. Sinais de RMN de ${ }^{1} \mathrm{H}(500 \mathrm{MHz}),{ }^{13} \mathrm{C}(125 \mathrm{MHz})$ e HMBC do metabólito M2 em $\mathrm{CDCl}_{3}, \delta$ em ppm, e comparação desses com os da literatura. 72

Tabela 11. Sinais de RMN de ${ }^{1} \mathrm{H}(500 \mathrm{MHz}),{ }^{13} \mathrm{C}(125 \mathrm{MHz})$ e HMBC do metabólito M3 em $\mathrm{CDCl}_{3}, \delta$ em ppm, e comparação desses com os da literatura.

Tabela 12. Sinais de RMN de ${ }^{1} \mathrm{H}(500 \mathrm{MHz}),{ }^{13} \mathrm{C}(125 \mathrm{MHz})$ e HMBC do metabólito M4 em $\mathrm{CD}_{3} \mathrm{OD}, \delta$ em ppm, e comparação desses com os da literatura (300 e $100 \mathrm{MHz}$ ).

Tabela 13. Sinais de RMN de ${ }^{1} \mathrm{H}(500 \mathrm{MHz}),{ }^{13} \mathrm{C}(125 \mathrm{MHz})$ e HMBC do metabólito M5 em $\mathrm{CDCl}_{3}, \delta$ em ppm, e comparação desses com os da literatura (400 e $100 \mathrm{MHz}$ ).

Tabela 14. Sinais de RMN de ${ }^{1} \mathrm{H}(500 \mathrm{MHz}),{ }^{13} \mathrm{C}(125 \mathrm{MHz})$ e HMBC do metabólito M6 em $\mathrm{CD}_{3} \mathrm{OD}, \delta$ em ppm. 84 
Tabela 15. Sinais de RMN de ${ }^{1} \mathrm{H}(500 \mathrm{MHz}),{ }^{13} \mathrm{C}(125 \mathrm{MHz})$ e HMBC do metabólito $\mathbf{M} 7$ em $\mathrm{CD}_{3} \mathrm{OD}, \delta$ em ppm, e comparação desses com os da literatura (400 e $100 \mathrm{MHz}$ ).

Tabela 16. Valores de $\mathrm{IC}_{50}(\mu \mathrm{M})$ apresentados pelo lapachol e seus metabólitos frente a linhagens celulares normais (GM07492-A) e tumorais (SKBR3). 90

Tabela 17. Sinais de RMN de ${ }^{1} \mathrm{H}(500 \mathrm{MHz}),{ }^{13} \mathrm{C}(125 \mathrm{MHz})$ e HMBC do metabólito $\mathrm{M8}$ em $\mathrm{CD}_{3} \mathrm{OD}, \delta$ em ppm. 98

Tabela 18. Valores de $\mathrm{IC}_{50}(\mu \mathrm{M})$ apresentados pela atovaquona e seu metabólito frente a linhagens celulares normais (GM07492-A) e tumorais (SKBR3). 100 


\section{LISTA DE ABREVIAÇÕES}

$\begin{array}{ll}\text { Acetona-d } & \text { Acetona deuterada } \\ \text { B.O.D. } & \text { Demanda bioquímica de oxigênio } \\ \text { CLAE } & \text { Cromatografia Líquida de Alta Eficiência } \\ \text { COSY } & \text { Correlation spectroscopy } \\ \text { DMEM } & \text { Dulbecco's Modified Eagle's Medium } \\ \text { DMSO } & \text { Dimetilsulfóxido } \\ \text { HMBC } & \text { Heteronuclear multiple bond coherence } \\ \text { HMQC } & \text { Heteronuclear multiple quantum coherence } \\ \text { L-cisteína/HCl } & \text { Cloridrato de L-cisteína } \\ \text { MeOH } & \text { Metanol } \\ \text { RMN } & \text { Ressonância Magnética Nuclear } \\ \text { RMN de }{ }^{13} \mathrm{C} & \text { Ressonância Magnética Nuclear de Carbono } \\ \text { RMN de }{ }^{1} \mathrm{H} & \text { Ressonância Magnética Nuclear de Hidrogênio } \\ \text { TFA } & \text { Ácido trifluoroacético } \\ \text { UV/VIS } & \text { Ultravioleta/Visível } \\ \text { XTT } & \text { 2,3-Bis-(2-metoxi-4-nitro-5-sulfofenil)-2H-tetrazolo-5-carboxanilida }\end{array}$




\section{LISTA DE SÍMBOLOS}

$\delta$

Deslocamento químico

$\lambda \quad$ Comprimento de onda

$\alpha \mathrm{D} \quad$ Rotação óptica específica

J Constante de acoplamento

s Simpleto

d Dubleto

dd Duplo dubleto

t Tripleto

m Multipleto

$\mathrm{Hz} \quad$ Hertz

$\mathrm{MHz} \quad$ Mega Hertz

rpm Rotações por minuto

$\mathrm{IC}_{50} \quad$ Concentração inibitória para $50 \%$ da população 


\section{INTRODUÇÃO}

\subsection{Quinonas}

As quinonas são classificadas quimicamente em benzoquinona, 1,4- e 1,2naftoquinona, e antraquinona (Figura 1). Esses compostos representam um grande grupo de substâncias presentes em muitas famílias de plantas, fungos, bactérias, e também no reino animal: em artrópodes (antraquinonas em insetos) e em equinodermas (quinonas isoprenoídicas em ouriços do mar) (MARTINEZ e BENITO, 2005; LEMOS et al., 2007).<smiles>O=C1C=CC(=O)C=C1</smiles>

benzoquinona<smiles>O=C1C=CC(=O)c2ccccc21</smiles>

1,4-naf toquinona<smiles>O=C1C=Cc2ccccc2C1=O</smiles>

1,2-naftoquinona<smiles>O=C1c2ccccc2C(=O)c2ccccc21</smiles>

antraquinona

Figura 1. Classificação química das quinonas.

Entre os fármacos utilizados no tratamento do câncer, as naftoquinonas constituem o grupo mais importante (TONHOLO et al., 1998). Assim, por exemplo, entre os fármacos quimioterápicos mais utilizados estão doxorrubicina, mitomicina e mitoxantrona, os quais possuem anel quinoidial em sua estrutura química (Figura 2) (SALUSTIANO et al., 2009; KOVACIC e SOMANATHAN, 2011).<smiles>COc1cccc2c1C(=O)c1c(O)c3c(c(O)c1C2=O)C[C@@H](C(=O)CO)C[C@@H]3O[C@H]1C[C@H](N)[C@H](O)[C@H](C)O1</smiles>

doxorrubicina<smiles>CC1=C(N)C(=O)C2=C(C1=O)N1CC3NC(C2)C31COC(N)=O</smiles>

mitomicina $\mathrm{C}$<smiles>O=C1c2c(O)ccc(O)c2C(=O)c2c(NCCNCCO)ccc(NCCNCCO)c21</smiles>

mitoxantrona

Figura 2. Estrutura química dos fármacos quimioterápicos detentores de anel quinona. 
O principal mecanismo proposto para a citotoxicidade apresentada pelas quinonas está relacionado ao estresse oxidativo causado por esses compostos, mas a capacidade de alquilação de nucleófilos celulares também apresenta correlação com tais efeitos biológicos (GOULART et al., 2004). Uma característica notável da química das quinonas é a sua facilidade em sofrer redução, transformando-se na forma reativa, chamada de semiquinona (Figura 3). A semiquinona, in vivo, é capaz de transferir um elétron a lipídeos, proteínas ou DNA, causando o aparecimento das espécies reativas de oxigênio. Tais espécies causam severo estresse oxidativo no interior das células a partir da formação de macromoléculas oxidadas (CRAWFORD et al., 1997; KOYAMA et al., 2001; DA SILVA JÚNIOR et al., 2009a).<smiles>CC1(C)OC2=C(CC1S(=O)(=O)O)C(=O)C(=O)c1ccccc12</smiles><smiles></smiles><smiles>C=CC</smiles><smiles></smiles>

$$
\|
$$<smiles>CC1(C)Oc2c(c(O)c(O)c3ccccc23)CC1C(=O)O</smiles><smiles>CC1(C)Oc2c(c(O)c(Cl)c3ccccc23)CC1C(=O)O</smiles>

Figura 3. Formação de semiquinona após análogo da $\beta$-lapachona ter sido irradiado na presença de doador de hidrogênio (Fonte: NETTO-FERREIRA et al., 2010).

Muitas naftoquinonas bioativas, como o lapachol, são encontradas em plantas típicas da América do Sul, principalmente em árvores da família Bignoniaceae, podendo 
representar cerca de 3-7\% da composição em massa do caule dessas espécies (CASTELLANOS et al., 2009; AUCÉLIO et al., 2013). As atividades biológicas do lapachol vêm sendo estudadas desde o início de 1960, incluindo atividades contra Mycobacterium tuberculosis e outros micro-organismos (EYONG et al., 2012), atividade anti-inflamatória (LANDA et al., 2013), moluscicida (SILVA et al., 2005), antimalárica (KAPADIA et al., 2001), atividade contra Trypanossoma cruzi (SALAS et al., 2008), entre outras. As pesquisas relacionadas às bioatividades apresentadas pelo lapachol continuam até os dias atuais. Recentemente, os efeitos gastroprotetores do lapachol foram comprovados (THEODULOZ et al., 2012), bem como seu potencial antidepressivo (EYONG et al., 2013a).

Embora o lapachol tenha sido licenciado no Brasil para ser usado na prática clínica como fármaco carcinostático (DA SILVA JÚNIOR et al., 2009b), e vários estudos relacionados às suas propriedades anti-câncer tenham sido reportados, observou-se que altas doses de lapachol eram necessárias para a obtenção da eficácia terapêutica, resultando em muitos efeitos colaterais aos pacientes (SUNASSEE et al., 2013). Estudos clínicos de fase I foram desenvolvidos com o lapachol e revelaram sua atividade anticoagulante como efeito colateral, devido à sua similaridade estrutural com a vitamina K (Figura 4) (MAEDA et al., 2008). Por esse motivo, o uso do lapachol como coadjuvante no tratamento de alguns tipos de câncer foi suspenso (HUSSAIN et al., 2007).<smiles>CC(C)=CCC1=C(O)C(=O)c2ccccc2C1=O</smiles>

lapachol<smiles>C=C(C)CCCC(C)(C)CCC1=C(C)C(=O)c2ccccc2C1=O</smiles>

vitamina $\mathrm{K}$

Figura 4. Semelhanças estruturais existentes entre lapachol e vitamina K. 
A partir de então, muitos pesquisadores começaram a desenvolver estudos com os derivados do lapachol objetivando estabelecer relações de estrutura-atividade e a obtenção de derivados bioativos, porém desprovidos de efeitos indesejáveis (CAMARA et al., 2001; PARRILHA et al., 2012; KANDIOLLER et al., 2013). Em 2009, uma importante naftoquinona derivada do lapachol, a $\beta$-lapachona, foi submetida a estudos clínicos de fase II como fármaco antitumoral (DA SILVA JÚNIOR et al., 2009a).

O lapachol também está estruturalmente relacionado à atovaquona (Figura 5), a qual apresenta ampla atividade contra diferentes espécies de Plasmodium, Pneumocystis e Toxoplasma (ROLAN et al., 1997). A atovaquona foi descoberta após 50 anos de pesquisas e é amplamente usada nos Estados Unidos, em combinação com proguanil $\left(\right.$ Malarone $^{\circledR}$ ), no tratamento e quimioprofilaxia da malária (NIXON et al., 2013). Plasmodium falciparum, parasita que causa a malária em humanos, possui alta capacidade de mutação e desenvolve rapidamente resistência contra os fármacos antimaláricos clássicos (ANDRADE-NETO et al., 2004; KESSL et al., 2007). Atovaquona é um análogo lipofílico do lapachol, um importante componente da transferência de elétrons nas mitocôndrias (EL HAGE et al., 2009). Sua atividade antimalárica é seletiva e está relacionada com a interferência no transporte de elétrons nas mitocôndrias do parasita, especificamente no complexo citocromo c redutase, resultando em colapso mitocondrial (ZHOU et al., 2009). Após ser administrada, a atovaquona liga-se 99,9 \% às proteínas plasmáticas (EL HAGE et al., 2009). Assim, diversos estudos focados na obtenção de derivados da atovaquona que apresentem melhor biodisponibilidade vêm sendo desenvolvidos (BARAMEE et al., 2006; EL HAGE et al., 2009; ZHOU et al., 2009). 


\section{Introdução}<smiles>CC(C)=CCC1=C(O)C(=O)c2ccccc2C1=O</smiles><smiles>O=C1C(O)=C([C@H]2CC[C@H](c3ccc(Cl)cc3)CC2)C(=O)c2ccccc21</smiles><smiles>CC(C)/C=C/C1=C(O)C(=O)c2ccccc2C1=O</smiles>

Figura 5. Estruturas químicas do lapachol (1), atovaquona (2) e isolapachol (3).

Outro importante análogo estrutural do lapachol é o isolapachol (Figura 5). Diversos estudos empregando o isolapachol na busca por derivados bioativos estão relatados, principalmente na busca por fármacos larvicidas e moluscidas. A toxicidade apresentada pelos derivados solúveis (sais de potássio) do lapachol e do isolapachol em diferentes estágios do ciclo de vida de Schistosoma mansoni foi avaliada por Lima e colaboradores. Ambos compostos mostraram significantes atividades contra formas adultas, cercárias e ovos. Quando o ensaio foi realizado com ovos de Artemia salina Leach, o sal de potássio do isolapachol mostrou-se altamente tóxico, enquanto o sal de potássio do lapachol não mostrou atividade (LIMA et al., 2002). As atividades do isolapachol contra Leishmania amazonensis e Leishmania braziliensis também são conhecidas (LIMA et al., 2004).

\subsection{Biotransformação}

Processos de biotransformação são utilizados pela humanidade há milhares de anos. Dados históricos apontam que a primeira biotransformação "verdadeira" ocorreu na antiga Babilônia com a transformação de etanol em ácido acético (vinagre) catalisada por Acetobacter (LERESCHE e MEYER, 2006).

Biotransformações são definidas como o uso de sistemas biológicos para realizar transformações químicas em substâncias que não constituem seus substratos naturais (HANSON, 1995). São também definidas como reações químicas catalisadas por 
células microbianas (em crescimento ou em repouso) ou por enzimas isoladas de microorganismos (PERVAIZ et al., 2013).

Os processos de biotransformação apresentam inúmeras vantagens quando comparados aos correspondentes métodos químicos (QI-HE et al., 2009), sendo economicamente e ecologicamente competitivos (HUISMAN et al., 2002). Além disso, a utilização das enzimas microbianas possibilita reações quimio-, régio- e enantioseletivas (MA et al., 2011).

Adicionalmente, algumas reações que não são possíveis de serem realizadas por processos químicos tradicionais são facilmente obtidas com as transformações microbianas (GARCÍA-GRANADOS et al., 2004). Entre as diferentes transformações catalisadas por esses sistemas enzimáticos, a hidroxilação régio e enantioseletiva de carbonos não ativados é particularmente interessante, já que tal transformação é dificilmente obtida a partir dos métodos químicos clássicos (GHOUMARI et al., 2006).

A enantiosseletividade observada em muitas biotransformações propicia a obtenção de produtos enantiomericamente puros a partir de misturas racêmicas (resolução de misturas racêmicas). As reações de biotransformação podem ser conduzidas em temperatura amena e em condições normais de temperatura e pressão e, na maioria dos casos, não há necessidade de proteger grupos funcionais (PATEL, 2002).

Embora algumas enzimas importantes, como as que catalisam as reações de hidroxilação, já tenham sido isoladas, a utilização de organismos vivos nas reações de biotransformação ainda é a técnica mais utilizada (GARCÍA-GRANADOS et al., 2004). Em reações de redução, por exemplo, a maioria das enzimas requer cofatores como $[\mathrm{NAD}(\mathrm{H})]$ e $[\mathrm{NADP}(\mathrm{H})]$. Em organismos vivos a regeneração desses cofatores ocorre naturalmente por processos metabólicos, tornando o método mais econômico e mais 
eficiente (FABER, 1997). Além disso, há muitos sistemas enzimáticos difíceis de serem obtidos em uma forma isolada estável (HANSON, 1995).

Dessa forma, as transformações químicas catalisadas por micro-organismos são úteis na investigação acerca da obtenção de compostos bioativos, detentores de estruturas inéditas, que poderão ser empregados no desenvolvimento de novos fármacos. Além disso, as transformações microbianas podem ser empregadas na elucidação das reações que um fármaco sofrerá in vivo após ser administrado por via oral.

Um importante fator na avaliação da segurança e eficácia dos fármacos é o conhecimento sobre seu metabolismo, que pode ser avaliado empregando-se os microorganismos. A realização de estudos sobre o metabolismo in vivo apresenta muitas desvantagens como o custo com os modelos animais, as questões éticas e as diferenças entre as espécies. Além disso, a toxicidade apresentada por muitos compostos limita a quantidade que pode ser administrada e, portanto pequenas quantidades de metabólitos podem ser isoladas. A expressão das enzimas da família do citrocromo P450 humanas pode ser reproduzida com sucesso em sistemas utilizando biotransformações fúngicas, possibilitando assim muitos estudos sobre o metabolismo dos fármacos (MA, WU e GUO, 2006; ASHA e VIDYAVATHI, 2009).

A biotransformação de fármacos é geralmente considerada no processo de desintoxicação, formando metabólitos mais polares, os quais podem ser facilmente excretados. Entretanto, os processos de biotransformação podem também levar à formação de metabólitos detentores de maior atividade farmacológica ou mais tóxicos que a substância de origem. Assim, processos capazes de gerar metabólitos com atividade farmacológica significativa ou menor toxicidade, quando comparados à 
molécula original, deveriam ser explorados durante a descoberta de novos fármacos (PERVAIZ et al., 2013).

A estratégia descrita acima foi utilizada na descoberta da ezetimiba, um inibidor da absorção do colesterol. Nesse estudo, um metabólito 30 vezes mais potente que a molécula de origem foi obtido (FURA, 2006).

As capacidades hidrolíticas e redutivas dos micro-organismos, especialmente fungos, têm sido bastante relatadas e usadas nas reações. Em relação às reações de oxidação, as hidroxilações nas posições $11 \alpha$ ou $11 \beta$ de esteróides são reações clássicas catalisadas tanto por micro-organismos quanto por mamíferos, as quais mostram as semelhanças existentes entre as enzimas monooxigenases de ambos os sistemas (VENISETTY e CIDDI, 2003). Assim, por exemplo, conhece-se a capacidade de

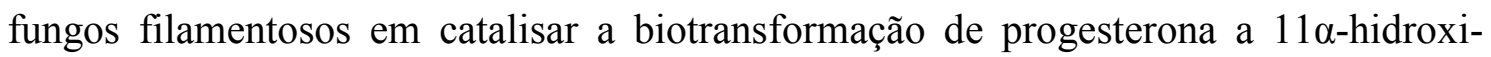
progesterona (KHATTAB e ABD-EL SALAM, 2012).

L-homofenilalanina é extensivamente usada na indústria farmacêutica como precursor para a produção de fármacos inibidores da enzima conversora da angiotensina (ECA), os quais possuem significantes aplicações clínicas no tratamento da hipertensão (Figura 6). Vários métodos químicos vêm sendo relatados para a síntese de L-homofenilalanina. Entretanto, a necessidade de métodos complexos, altos custos e a poluição ambiental implicados em tal síntese, fazem com que o método de escolha para a produção de L-homofenilalanina seja a utilização da biocatálise utilizando as enzimas hidantoinase e carbamoilase para a biotransformação do ácido homofenilalanilcarbamólico (AHMAD, OH e SHUKOR, 2009). 
<smiles>N[C@@H](CCc1ccccc1)C(=O)O</smiles>

L-homofenilalanina<smiles>CCOC(=O)[C@H](CCc1ccccc1)N[C@H](C(=O)O)C(=O)CN1CCC[C@H]1C(=O)O</smiles>

Enalapril<smiles>NCCCC[C@H](N[C@@H](CCc1ccccc1)C(=O)O)C(=O)CN1CCC[C@H]1C(=O)O</smiles>

Lisinopril<smiles>CCOC(=O)[C@H](NC(CCc1ccccc1)C(=O)OCC(=O)O)N(CC(=O)O)C1Cc2ccccc2C1</smiles>

Delapril<smiles>CCOC(=O)[C@H](CCc1ccccc1)N[C@H](C(=O)O)C(=O)CN1Cc2ccccc2C[C@H]1C(=O)O</smiles>

Quinapril

Figura 6. Exemplos de fármacos inibidores da ECA provenientes da Lhomofenilalanina (Fonte: AHMAD, OH e SHUKOR, 2009).

Quando se analisa os dados disponíveis na literatura acerca dos estudos sobre a biotransformação de naftoquinonas, observa-se que há reduzido número de publicações. Nesse sentido, a naftoquinona INO5042 (Figura 7) foi utilizada como substrato para uma série de fungos e bactérias. Duas linhagens de Streptomyces, S. platensis e $S$. cinnamonesis, foram ativas na biotransformação e catalisaram o rompimento do anel quinona (FOSSE et al., 2004). 


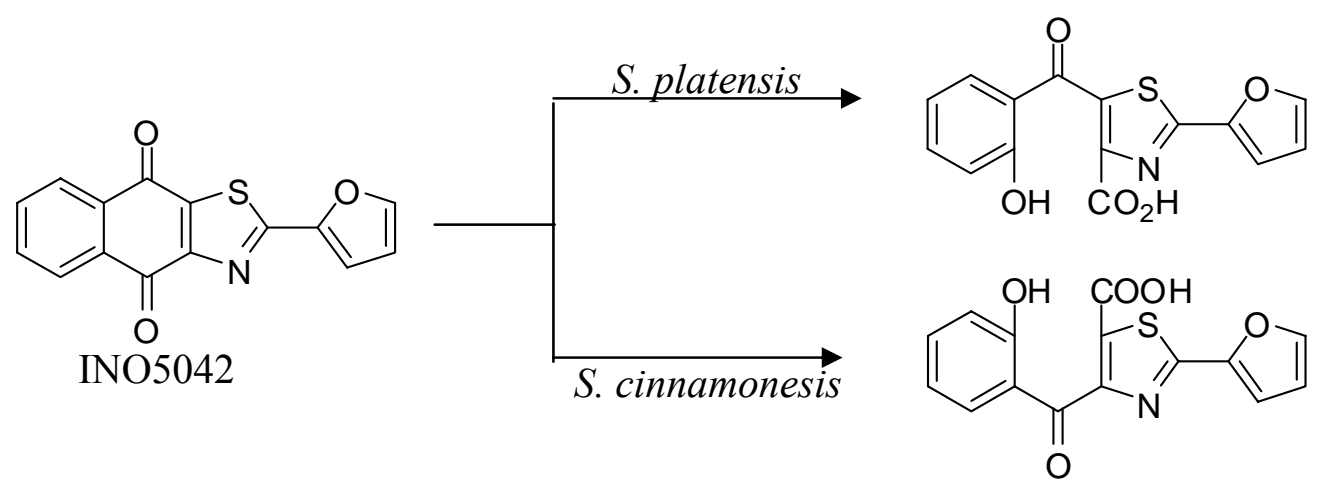

Figura 7. Biotransformação da naftoquinona INO5042 por duas linhagens de Streptomyces (Fonte: FOSSE et al., 2004).

A transformação bacteriana da naftoquinona chiquonina foi investigada utilizando bactérias intestinais humanas. No total, 24 anaeróbios foram avaliados e Bacteroides fragilis subsp. thetaotus mostrou a habilidade de transformar extensivamente tal naftoquinona (Figura 8) (MESELHY et al., 1994).

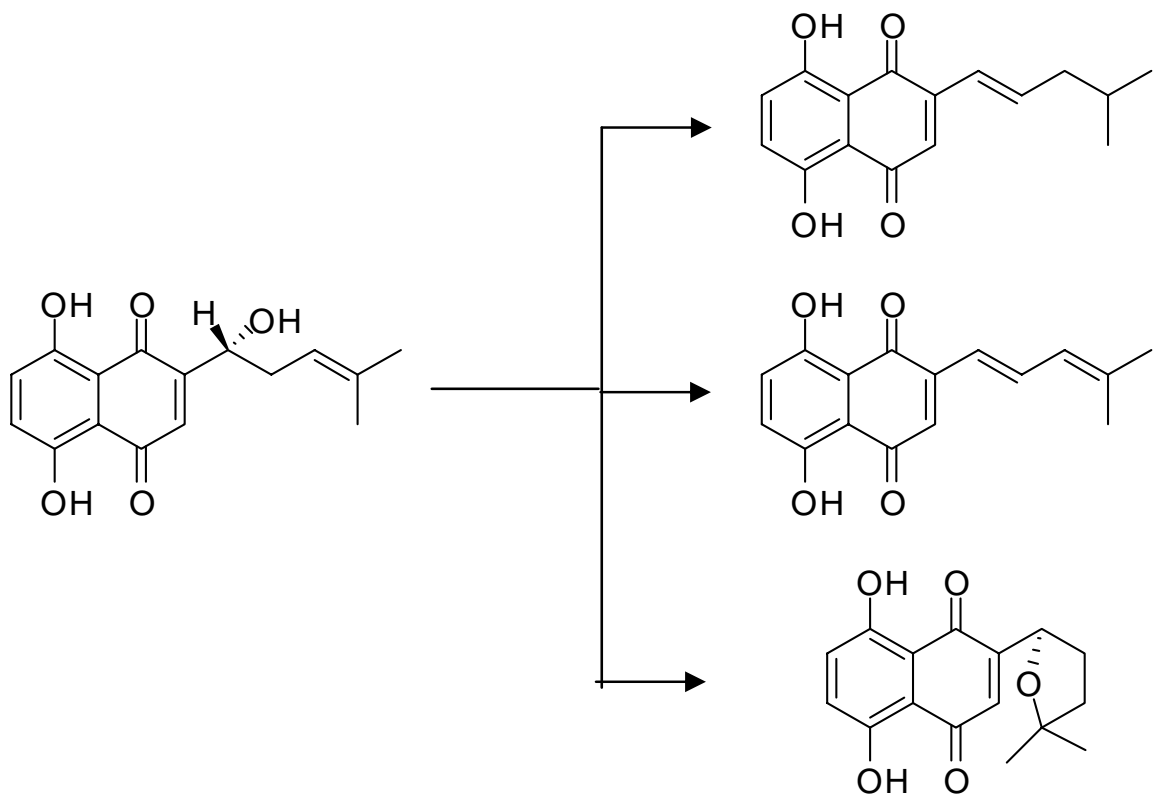

Figura 8. Biotransformação da chiconina por Bacteroides fragilis subsp. thetaotus (Fonte: MESELHY et al., 1994).

Em 2003, Venisetty e Ciddi publicaram uma revisão acerca das semelhanças existentes entre o metabolismo dos xenobióticos realizado por mamíferos e por fungos filamentosos, além de apontarem as vantagens implicadas na utilização de modelos 
microbianos para a predição do metabolismo, o que contribui para o desenvolvimento de novos fármacos. Na Tabela 1 estão apresentadas algumas das comparações realizadas por tais pesquisadores.

Tabela 1. Comparação entre os metabólitos de mamíferos com os microbianos de alguns produtos naturais (Fonte: VENISETTY e CIDDI, 2003).

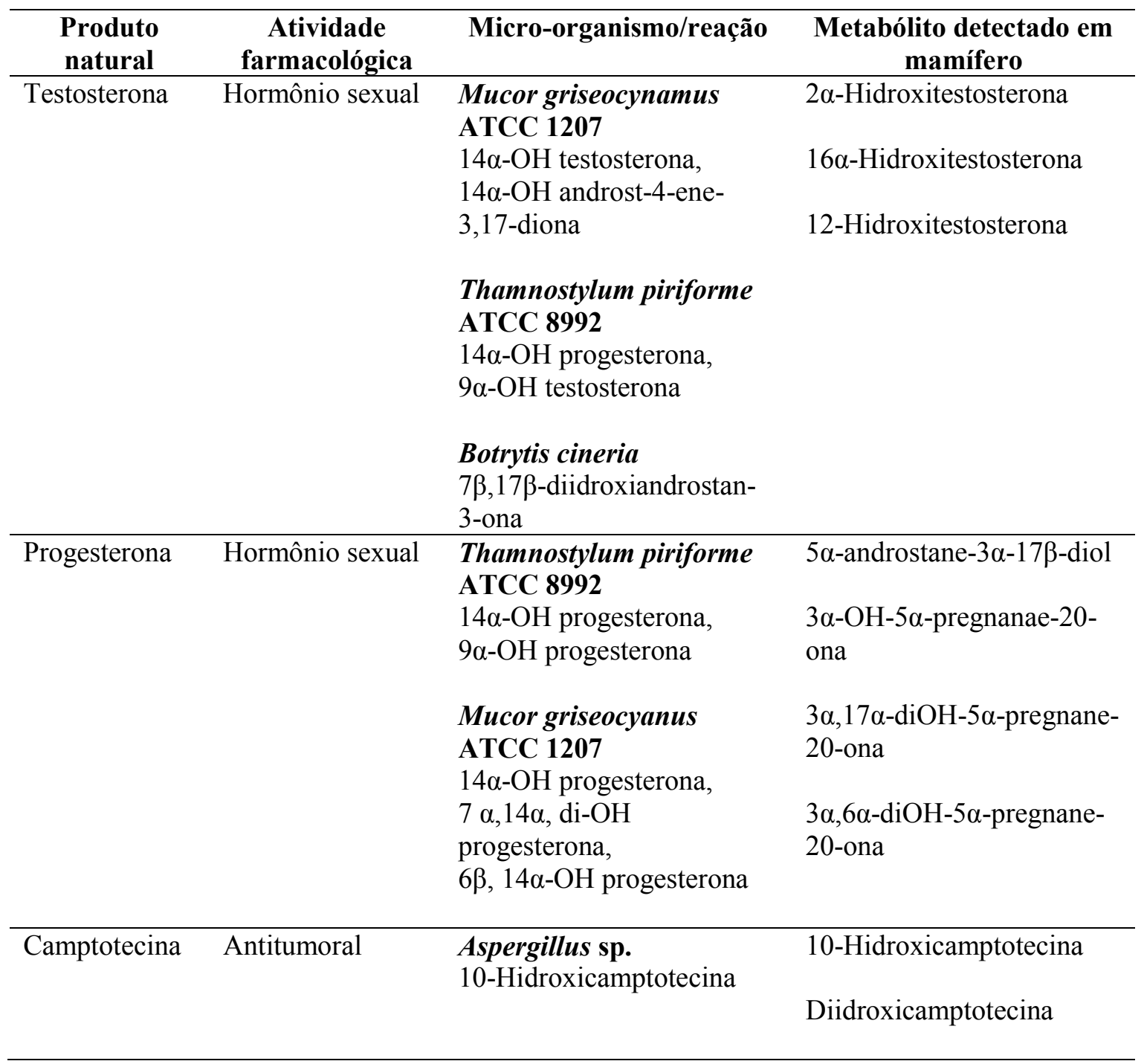


Tabela 1. Continuação

\begin{tabular}{|c|c|c|c|}
\hline $\begin{array}{c}\begin{array}{c}\text { Produto } \\
\text { natural }\end{array} \\
\end{array}$ & $\begin{array}{c}\text { Atividade } \\
\text { farmacológica }\end{array}$ & Micro-organismo/reação & $\begin{array}{c}\text { Metabólito detectado em } \\
\text { mamífero }\end{array}$ \\
\hline Artemisinina & Antimalárico & $\begin{array}{l}\text { Nocardia corallina ATCC } \\
19070 \\
\text { Desoxiartemisinina } \\
\text { Penicillium chrysogenum } \\
\text { ATCC } 4480 \\
3 \alpha-\mathrm{OH} \text { desoxiartemisinina }\end{array}$ & $\begin{array}{l}3 \alpha \text {-OHdesoxiartemisinina } \\
\text { Diidroartemisinina } \\
\text { Desoxiartemisinina }\end{array}$ \\
\hline $\begin{array}{l}\text { Taxol } \\
\text { (Paclitaxel) }\end{array}$ & Antitumoral & $\begin{array}{l}\text { Nocardioides albus } \\
\text { 13-deacilpaclitaxel }\end{array}$ & 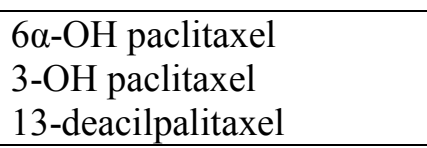 \\
\hline Cafeína & $\begin{array}{l}\text { Estimulante do } \\
\text { Sistema Nervoso } \\
\text { Central }\end{array}$ & $\begin{array}{l}\text { Pseudomonas putida } \\
\text { Teobromina } \\
\text { 3-desmetil cafeína } \\
\text { Pencillium roqueforti } \\
\text { Degradação do anel } \\
\text { imidazol }\end{array}$ & $\begin{array}{l}\text { 1-metilxantina } \\
\text { 1-metil ácido úrico } \\
\text { (degradação do anel } \\
\text { imidazol) }\end{array}$ \\
\hline Lapachol & $\begin{array}{l}\text { Antitumoral, } \\
\text { antibiótico }\end{array}$ & $\begin{array}{l}\text { Curvularia lunata } \\
\text { Deidro- } \alpha \text {-lapachona } \\
\\
\text { Beauvaria bassiana } \\
\text { Lomatiol } \\
\text { Ácido lomático } \\
\text { Acetato de lomatiol } \\
\end{array}$ & $\begin{array}{l}\text { Lomatiol } \\
\text { Ácido lomático } \\
\text { Formação de glicuronídeo }\end{array}$ \\
\hline
\end{tabular}

\subsection{Fungos filamentosos}

Os fungos são os sistemas celulares mais frequentemente estudados para a aplicação nas reações de biotransformação (MA et al., 2011), pois estes possuem enzimas capazes de catalisar grande variedade de reações, tais como: hidroxilação, oxidação, redução, epoxidação, O-desmetilação, O-desalquilação, O-metilação, glicosilação, entre outras (SRISILAM e VEERESHAM, 2003).

Em 1974, Smith e Rosazza foram os primeiros a propor o uso dos fungos como modelo para o metabolismo dos mamíferos. O metabolismo dos xenobióticos em mamíferos ocorre principalmente no fígado, onde as enzimas ali presentes promovem 
reações que aumentam a polaridade dos produtos facilitando a excreção. Os metabólitos obtidos usando fungos filamentosos são similares àqueles obtidos em reações de fase I (funcionalização) ou fase II (conjugação) catalisadas pelas enzimas do fígado (KUTRZEBA et al., 2009).

Entre os fungos filamentosos, os Mucorales são amplamente espalhados na natureza e compõe a maior ordem dentro dos Zigomicetos, englobando importantes gêneros como Absidia, Mucor e Rhizopus. Estes são micro-organismos de rápido crescimento e o micélio é descrito como "semelhante ao algodão". Durante a reprodução assexual há formação de esporos nos esporangióforos e, na reprodução sexual, aparecem os zigósporos (HOLLMANN et al., 2008). Algumas espécies de Mucor são muito usadas em biotecnologia devido à produção de enzimas com alta atividade proteolítica e lipolítica (MA et al., 2011).

O dimorfismo é uma característica relativamente comum apresentada por diversos fungos que ora apresentam-se sob a forma leveduriforme, ora sob a forma filamentosa (LÜBBEHÜSEN, NIELSEN e MCINTYRE, 2003). O dimorfismo que aparece nos Mucorales é um processo de diferenciação que envolve uma série de eventos, nos quais estímulos internos são recebidos por sensores celulares e produzem como reposta alterações morfológicas nas células. O estabelecimento de ambiente microaerófilo causa alterações no potencial redox das células, provocando a transição da forma micelial para leveduriforme (RUIZ-HERRERA, 1993). Sabe-se que sob baixos níveis de glicose ou dióxido de carbono, ou ambos, o desenvolvimento sob a forma de hifas é predominante; por outro lado, sob altos níveis, ocorre eliciação do desenvolvimento sob a forma de leveduras (BARTNICKI-GARCIA, 1968).

Dentre os fungos filamentosos empregados nos estudos de biotransformação, o gênero Mucor é um dos mais empregados. Quando Mucor circinelloides f. griseo- 
cyanus IFO 4563 foi utilizado na biotransformação do antibiótico claritromicina (Figura 9A), um derivado 14- $R$-hidroxilado foi obtido, sendo que tal transformação reduziu a atividade antimicrobiana in vitro (SASAKI et al., 1988). O agente citotóxico daunomicina (Figura 9B) foi biotransformado por Mucor spinosus de forma similar ao que ocorre no metabolismo de mamíferos: o grupo carbonílico da posição C-13 foi reduzido à hidroxila (MARSHALL et al., 1978). Mucor circinelloides AS 3.3421, foi capaz de hidroxilar ondansetrona (Figura 9C), um antagonista de receptores 5hidroxitriptamina, na posição C-1 (DUAN et al., 2006). A gastrodina (Figura 9D), produto natural com diversas atividades neurológicas, foi completamente metabolizada por Mucor spinosus 3.3450, com a formação do álcool p-hidroxibenzílico (ZHAN et al., 2001). A biotransformação do agente neuroléptico risperidona (Figura 9E) por Mucor rouxii NRRL 1894 mostrou ser enentiosseletiva com a formação de um metabólito ativo quiral (JESUS et al., 2011). O albendazol (Figura 9F) é um agente anti-helmíntico de amplo espectro. Sua biotransformação por Mucor roxii NRRL 1894 mostrou ser uma excelente alternativa na obtenção de enatiômeros com bons rendimentos (HILÁRIO et al., 2012). Os exemplos descritos anteriormente mostram quão grande é a versatilidade dos fungos filamentosos do gênero Mucor em realizar transformações químicas nos substratos. 


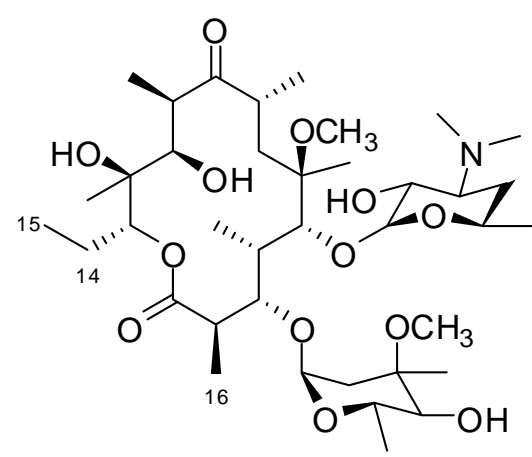

A<smiles>Cc1nccn1CC1CCc2c(c3ccccc3n2C)C1=O</smiles>

C<smiles>Cc1nc2n(c(=O)c1CCN1CCC(c3noc4cc(F)ccc34)CC1)CCCC2</smiles>

E<smiles>COc1cccc2c1C(=O)c1c(O)c3c(c(O)c1C2=O)C[C@@](O)(C(=O)CO)C[C@H]3OC1CC(N)C(O)C1(C)O</smiles>

B<smiles>CC1(O)C(O)C(O)C(O)C(Oc2ccc(CO)cc2)C1O</smiles>

D<smiles>CCCSc1ccc2nc(NC(=O)OC)[nH]c2c1</smiles>

$\mathbf{F}$

Figura 9. Diferentes fármacos empregados nas biotransformações catalisadas por Mucor sp.

Fungos do gênero Aspergillus também são amplamente utilizados em biotecnologia para a produção de ingredientes alimentares ou farmacêuticos, além de enzimas industriais. Tais fungos exibem grande versatilidade metabólica, desenvolvendo-se em uma ampla quantidade de substratos e sob diferentes condições ambientais. Estes são capazes de degradar diferentes compostos graças às suas enzimas que realizam reações como oxidações, hidroxilações e desmetilações (PEL et al., 2007). 
Um estudo empregando Aspergillus niger na biotransformação do ácido entpimaradienóico foi recentemente relatado. Nesse trabalho, os autores obtiveram quatro derivados, cujas principais reações ocorridas foram hidroxilações, desidrogenações e migrações das insaturações. Um dos metabólitos obtidos, metil $7 \alpha$-hidroxi ent-pimara8(14),15-dien-19-oato (Figura 10), apresentou eficiente atividade antiespasmódica (SEVERIANO et al., 2013).

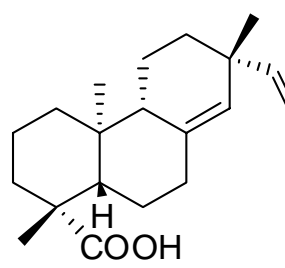

1

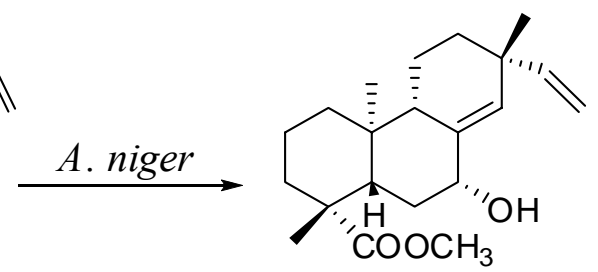

2

Figura 10. Transformação de ácido ent-pimaradienóico (1) em metil $7 \alpha$-hidroxi ent-pimara-8(14),15-dien-19-oato (2) por A. niger (Fonte: SEVERIANO et al., 2013).

Em relação ao gênero Botrytis, a espécie mais conhecida é a cinerea (STAATS, VAN BAARLEN e VAN KAN, 2005). O mofo cinzento ocasionado pelo fungo $B$. cinerea (Persoon) é uma fitopatogenia bastante comum e observada em pelo menos 235 plantas, principalmente dicotiledôneas e monocotiledôneas não gramináceas (JARVIS, 1977). A infecção causada por este fungo na planta hospedeira é intermediada por numerosas enzimas extracelulares e metabólitos secundários, tendo cada um destes um papel importante durante o processo de infecção (ELAD, MALATHRAKIS e DIK, 2004; COLLADO, SÁNCHES e HANSON, 2007). Diversos metabólitos secundários obtidos de processos fermentativos de $B$. cinerea apresentaram atividade fitotóxica e apoptótica (COLLADO et al., 2000).

As atividades antifúngicas dos sesquiterpenos patchoulol, ginsenol, cedrol e globulol frente a $B$. cinerea são conhecidas. Quando tais sesquiterpenos foram biotransformados por $B$. cinerea, ocorreu a diminuição do efeito inibitório, sugerindo a 
associação do mecanismo de desintoxicação usado por aquele fungo ao processo de biotransformação. As principais reações catalisadas por $B$. cinerea nos sesquiterpenos avaliados foram hidroxilações (ALEU et al., 2001).

Os fungos filamentosos também podem ser empregados na predição do metabolismo in vivo de fármacos. Vários estudos vêm demonstrando que espécies de Cunninghamella possuem sistema enzimático análogo ao do citocromo $\mathrm{P} 450$ de mamíferos. Tratam-se de fungos filamentosos encontrados no solo e em plantas, principalmente em zonas subtropicais e na região do Mediterrâneo. O gênero contém 14 espécies, sendo Cunninghamella elegans, Cunninghamella echinulata e Cunninghamella bertholletiae as mais comuns (ASHA e VIDYAVATHI, 2009).

A existência do citocromo P450 foi proposta em 1970, sendo provavelmente a forma usada por micro-organismos primitivos em processos de detoxificação. O estudo do sistema P450 de fungos filamentosos é de grande interesse acadêmico, pois oferece possibilidades no entendimento sobre a participação do citocromo P450 humano no metabolismo de xenobióticos (papel na farmacologia e toxicologia). Além disso, o citocromo P450 de micro-organismos é capaz de catalisar uma grande quantidade de reações, exercendo papel chave na produção de produtos naturais, em processos de biorremediação e biocatálise, bem como funcionando como alvo de alguns fármacos. Muitas bactérias são desprovidas do citocromo P450, como por exemplo, Escherichia coli, enquanto outras o possuem em quantidade bastante reduzida, como os microorganismos probióticos (KELLY e KELLY, 2013).

\subsection{Bactérias lácticas}

As bactérias lácticas também são conhecidas como probióticas, sendo definidas como suplementos microbianos vivos capazes de gerar benefícios à saúde do hospedeiro 
quando ingeridos em quantidade apropriada (FAO/WHO, 2002). Em condições fisiológicas normais, tais bactérias não se encontram no estômago, dadas as suas condições de acidez (HAEBERLIN e FRIEND, 1992; FAIGLE, 1993). O número de micro-organismos aumenta gradualmente ao longo do intestino delgado e encontra a sua expressão máxima em torno da válvula ileocecal (FAIGLE, 1993).

Atualmente são conhecidas mais de 800 espécies de bactérias que habitam o cólon e entre estas estão Bifidobacterium sp. e Lactobacillus sp. (VAN DER MOOTER e KINGET, 1995; BACKHED et al., 2005). São notáveis suas capacidades de metabolizar fármacos e outros xenobióticos (YANG, CHU e FIX, 2002), como por exemplo omeprazol, digoxina, clonazepam, insulina e prontosil (SOUSA et al., 2008). Além disso, estudos sobre processo de detoxificação utilizando bactérias probióticas também vêm sendo realizados (YOUNG et al., 2007; GUAN et al., 2009; MECA, RITIENI e MAÑES, 2012). Quando os fármacos entram em contato com a microbiota gastrointestinal, eles podem tornar-se farmacologicamente ativos, inativos ou tóxicos (BASIT e LACEY, 2001). As enzimas microbianas transformam compostos exógenos em substâncias benéficas, como no caso dos fitoestrógenos (RAIMONDI et al., 2009) ou prejudiciais (derivados tóxicos, mutagênicos ou carcinogênicos). Dessa forma, a ação da microbiota sobre fármacos deveria integrar os procedimentos para desenvolvimento de novos medicamentos no mundo todo (SOUSA et al., 2008).

Estudos empregando as enzimas produzidas pelas bactérias intestinais humanas vêm sendo realizados. Assim, em estudos empregando lignanas glicosiladas, reações de desglicosilação e desmetilação foram observadas (CLAVEL et al., 2006). Quando o metabolismo de aminas aromáticas carcinogênicas foi investigado, metabólitos hidroxilados atóxicos foram obtidos (VANHAECKE et al., 2008). Várias doenças inflamatórias afetam o intestino e o tratamento utilizando pró-fármacos é uma 
abordagem útil. O sucesso do tratamento é garantido pela ação das enzimas produzidas pelos micro-organismos do trato gastrointestinal que liberam o fármaco ativo (YANG, CHU e FIX, 2002).

Em contraste com a predominância do metabolismo oxidativo e conjugativo que ocorre na mucosa do fígado e do intestino, o metabolismo bacteriano é composto, em grande parte, por degradação hidrolítica e redutora com um grande potencial para a ativação metabólica e desintoxicação de xenobióticos (ILETT et al., 1990).

Micro-organismos do gênero Bifidobacterium exercem muitos efeitos benéficos no hospedeiro e estão sendo cada vez mais utilizados em alimentos funcionais e produtos farmacêuticos (RAIMONDI et al., 2009).

O gênero Lactobacillus distribui-se por vários nichos ecológicos, constituindo importante parte da microbiota dos tratos intestinal e genital do homem e de animais superiores. Sua distribuição é afetada por vários fatores ambientais como $\mathrm{pH}$, disponibilidade de oxigênio, quantidade de substrato, presença de secreções e interações bacterianas. Raramente estão associados a casos de infecção gastrointestinal e extraintestinal, sendo considerados micro-organismos não-patogênicos capazes de promover a saúde do trato gastrointestinal e geniturinário humano (GOMES e MALCATA, 1999). 


\section{OBJETIVOS}

\subsection{Objetivo geral}

Desenvolver processos para a realização de estudos sobre o metabolismo do lapachol e do seu sal de potássio por bactérias do trato gastrointestinal e fungos filamentosos, bem como utilizar os processos desenvolvidos para a realização de estudos comparativos entre a biotransformação do lapachol, do isolapachol e da atovaquona, visando ao isolamento e à avaliação da citotoxicidade dos metabólitos produzidos.

\subsection{Objetivos específicos}

$\checkmark$ Determinar as condições para obtenção de esporos das linhagens dos fungos filamentosos;

$\checkmark$ Determinar as condições para o crescimento das bactérias do trato gastrointestinal;

$\checkmark$ Estabelecer as condições de cultivo em meio pré-fermentativo para obtenção de biomassa dos fungos filamentosos;

$\checkmark$ Estabelecer as condições de cultivo (padronização do crescimento) das bactérias do trato gastrointestinal;

$\checkmark$ Obter os substratos (lapachol, sal de potássio do lapachol, isolapachol e atovaquona);

$\checkmark$ Determinar a concentração de cada substrato a ser utilizada nos processos de biotransformação, por meio do ensaio de concentração inibitória mínima;

$\checkmark$ Avaliar a influência do meio de cultura, do tempo de incubação e do uso de diferentes micro-organismos nas reações de biotransformação do lapachol e de seu sal de potássio, mediante avaliação dos perfis químicos; 
$\checkmark$ Selecionar os processos mais promissores para o desenvolvimento em escala preparativa, visando à obtenção dos metabólitos;

$\checkmark$ Isolar e determinar as estruturas químicas dos metabólitos majoritários obtidos;

$\checkmark$ Realizar estudo comparativo entre a biotransformação do lapachol, do isolapachol e da atovaquona, utilizando-se das condições mais promissoras observadas durante os estudos com o lapachol;

$\checkmark$ Avaliar a atividade citotóxica dos metabólitos obtidos frente às linhagens celulares de câncer de mama humano SKBR-3 e de fibroblastos normais humanos GM07492-A. 


\section{MATERIAL E MÉTODOS}

\subsection{Meios de cultura}

Meios sólidos:

Ágar rico: $4,0 \%$ de glicose, $0,2 \%$ de extrato de levedura, 3,0\% de ágar (Synth), 0,4\% de L-asparagina, 1,0\% de $\mathrm{KH}_{2} \mathrm{PO}_{4}, 0,1 \%$ de $\mathrm{MgSO}_{4} .7 \mathrm{H}_{2} \mathrm{O}$, 2,0 mL de solução sutter $(0,01 \%$ de tiamina, $2,0 \%$ de ácido cítrico, $0,015 \%$ de $\mathrm{Fe}\left(\mathrm{NO}_{3}\right)_{3} .9 \mathrm{H}_{2} \mathrm{O}, \quad 0,01 \%$ de $\mathrm{ZnSO}_{4} .7 \mathrm{H}_{2} \mathrm{O}, \quad 0,003 \%$ de $\mathrm{MnSO}_{4} \cdot \mathrm{H}_{2} \mathrm{O}, 0,0005 \%$ de $\mathrm{CuSO}_{4} \cdot 5 \mathrm{H}_{2} \mathrm{O}, 0,0005 \%$ de $\mathrm{Na}_{2} \mathrm{MoO}_{4} \cdot 2 \mathrm{H}_{2} \mathrm{O}$ ), 2,0 mL de solução cálcio sutter $\left(0,28 \%\right.$ de $\left.\mathrm{CaCl}_{2}\right)$;

$\checkmark$ Ágar tomate: $1,0 \mathrm{~kg}$ de tomates maduros (sem pele e triturados), 20,0 g de ágar (Synth), 1 L de água;

$\checkmark$ Ágar MH: Ágar Mueller Hinton (Himedia);

$\checkmark$ Ágar MRS: Caldo DeMan-Rogosa-Sharpe (DE MAN, ROGOSA e SHARPE, 1960) acrescido de 1,8\% de ágar (Acumedia);

Malte: 2,0\% de extrato de malte (Himedia), 2,0\% de glicose (Synth), 0,1\% de peptona (Himedia), 1,8\% de ágar (Himedia).

Meios líquidos:

Czapek: $3,0 \%$ de sacarose (Synth), 0,2\% de $\mathrm{NaNO}_{3}$ (Vetec), 0,1\% de $\mathrm{K}_{2} \mathrm{HPO}_{4}$ (Vetec), $0,05 \%$ de $\mathrm{MgSO}_{4} \cdot 7 \mathrm{H}_{2} \mathrm{O}$ (Vetec), $0,05 \%$ de $\mathrm{KCl}$ (Vetec) e 0,001\% de $\mathrm{FeSO}_{4} .7 \mathrm{H}_{2} \mathrm{O}$ (Vetec), pH 6,0;

$\checkmark$ Czapek Dox: 5,0\% de glicose (Synth), 0,1\% de extrato de levedura (Synth), 0,5\% de $\mathrm{KH}_{2} \mathrm{PO}_{4}$ (Synth), 0,2\% de $\mathrm{NaNO}_{3}$ (Synth), 0,05\% $\mathrm{MgSO}_{4} \cdot 7 \mathrm{H}_{2} \mathrm{O}$ (Synth), 0,001\% de $\mathrm{FeSO}_{4} .7 \mathrm{H}_{2} \mathrm{O}$ (Synth), pH 6,0; 
$\checkmark$ Koch's K1: $0,18 \%$ de glicose (Synth), 0,06\% de peptona (Himedia) e 0,04\% de extrato de levedura (Himedia), $\mathrm{pH} 5,0 ;$

$\checkmark$ Koch's K1 modificado: $0,18 \%$ de glicose (Synth), $0,06 \%$ de aminoácido* (Ajinomoto) e 0,04\% de extrato de levedura (Himedia), $\mathrm{pH}$ 5,0

* fenilalanina, triptofano ou prolina

$\checkmark$ PDB: Caldo dextrose batata (Acumedia);

$\checkmark$ Meio pré-fermentativo de Jackson (JACKSON et al., 1993): 0,25\% de pó de milho (Veranita), 1,0\% de glicose (Synth), 1,0\% de farinha de aveia (Quaker), 4,0\% de extrato de tomate (Quero), 1,0\% de $\mathrm{CaCl}_{2}$. $2 \mathrm{H}_{2} \mathrm{O}$ (Vetec) e $10,0 \mathrm{~mL} / \mathrm{L}$ da solução com traços de elementos $(0,1 \%$ de $\mathrm{FeSO}_{4} \cdot 7 \mathrm{H}_{2} \mathrm{O}$ (Vetec), 0,1\% de $\mathrm{MnCl}_{2} \cdot 4 \mathrm{H}_{2} \mathrm{O}$ (Vetec), 0,0025\% de $\mathrm{CuCl}_{2} .2 \mathrm{H}_{2} \mathrm{O}$ (Vetec), $0,01 \%$ de $\mathrm{CaCl}_{2} .2 \mathrm{H}_{2} \mathrm{O}$ (Vetec), $0,056 \%$ de $\mathrm{H}_{3} \mathrm{BO}_{3}$ (Vetec), $0,0019 \%$ de $\left(\mathrm{NH}_{4}\right)_{6} \cdot \mathrm{MoO}_{2} .4 \mathrm{H}_{2} \mathrm{O}$ (Vetec) e $0,02 \%$ de $\mathrm{ZnSO}_{4}$. $7 \mathrm{H}_{2} \mathrm{O}$ (Vetec), $\mathrm{pH} 5,0$;

$\checkmark$ Meio líquido rico: $4,0 \%$ de glicose, $0,2 \%$ de extrato de levedura, $0,4 \%$ de L-asparagina, $1,0 \%$ de $\mathrm{KH}_{2} \mathrm{PO}_{4}, 0,1 \%$ de $\mathrm{MgSO}_{4} .7 \mathrm{H}_{2} \mathrm{O}, 2,0 \mathrm{~mL}$ de solução sutter $(0,01 \%$ de tiamina, $2,0 \%$ de ácido cítrico, $0,015 \%$ de $\mathrm{Fe}\left(\mathrm{NO}_{3}\right)_{3} \cdot 9 \mathrm{H}_{2} \mathrm{O}, \quad 0,01 \%$ de $\mathrm{ZnSO}_{4} \cdot 7 \mathrm{H}_{2} \mathrm{O}, \quad 0,003 \%$ de $\mathrm{MnSO}_{4} \cdot \mathrm{H}_{2} \mathrm{O}$, $0,0005 \%$ de $\mathrm{CuSO}_{4} .5 \mathrm{H}_{2} \mathrm{O}, 0,0005 \%$ de $\left.\mathrm{Na}_{2} \mathrm{MoO}_{4} \cdot 2 \mathrm{H}_{2} \mathrm{O}\right), 2,0 \mathrm{~mL}$ de solução cálcio sutter $\left(0,28 \%\right.$ de $\left.\mathrm{CaCl}_{2}\right)$, $\mathrm{pH} 7,0$;

Caldo MH: Caldo Mueller Hinton (Himedia);

Caldo MRS: Caldo DeMan-Rogosa-Sharpe (Acumedia), pH 6,7 (SOUZA et al., 2008). 
Todos os meios de cultura foram preparados com água destilada e esterilizados em autoclave (Phoenix) a $121^{\circ} \mathrm{C}$, por 15 minutos.

\subsection{Obtenção dos substratos}

\subsubsection{Obtenção do lapachol e atovaquona}

Lapachol (pureza 90\%) e atovaquona (pureza $\geq 98 \%$ ) foram adquiridos da Sigma-Aldrich $^{\circledR}$

\subsubsection{Obtenção do sal de potássio do lapachol}

O sal de potássio do lapachol foi sintetizado por meio de reação ácido base com solução etanólica de carbonato de potássio e purificado por meio de lavagem com éter etílico.

O lapachol foi solubilizado em solução etanólica de carbonato de potássio (1 equivalente) em balão de $50 \mathrm{~mL}$. Foi iniciada agitação por 30 minutos, ou até consumo completo da quinona de partida. Terminada a reação, a solução foi evaporada sob pressão reduzida. O resíduo sólido obtido foi lavado por três vezes com éter etílico e levado ao alto vácuo para secagem completa. O material seco obtido tratava-se do sal de potássio do lapachol, obtido em rendimento quantitativo e com pureza de 95\% (LIMA et al., 2002).

\subsubsection{Obtenção do isolapachol}

O isolapachol foi sintetizado a partir da lausona, por condensação com isovaleraldeído em meio ácido. Para isso, foram adicionados $2 \mathrm{~mL}$ de ácido clorídrico concentrado e $5 \mathrm{~mL}$ de isovaleraldeído à uma solução em ebulição composta por $2 \mathrm{~g}$ de lausona (11,5 mmol) e $35 \mathrm{~mL}$ de ácido acético glacial. A mistura foi mantida em 
agitação a $80{ }^{\circ} \mathrm{C}$ durante duas horas e então vertida em $200 \mathrm{~mL}$ de água destilada. Após 12 horas, o resíduo oleoso foi separado e dissolvido em $100 \mathrm{~mL}$ de éter. A solução etérea foi extraída com duas porções de $200 \mathrm{~mL}$ cada de hidróxido de sódio 1\%, gerando uma solução aquosa básica de coloração violeta. Essa última solução foi acidificada com ácido clorídrico concentrado, resultando em um resíduo sólido que foi recristalizado em éter de petróleo e etanol, fornecendo os cristais de isolapachol (1,3 g; 46,7\%) (VESSECCHI et al., 2012).

\subsection{Micro-organismos utilizados nos processos de biotransformação}

Os fungos filamentosos utilizados foram: Mucor rouxii NRRL 1894 fornecido pelo Dr. C.W. Hesseltine (Northern Utilization Research and Development Division, ARS, USDA, Peoria, IL, USA), Aspergillus ochraceus e Rhizopus stolonifer mantidos pela coleção de fungos do Departamento de Biologia da Faculdade de Filosofia, Ciências e Letras de Ribeirão Preto, Universidade de São Paulo, sob responsabilidade da Profa. Dra. Maria de Lourdes Teixeira de Moraes Polizeli e do Prof. Dr. João Atílio Jorge; Aspergillus brasiliensis (ATCC 16404), Cunninghamella echinulata var. elegans (ATCC 8688a), Cunninghamella elegans (ATCC 10028b) e Curvularia lunata (ATCC 12017) foram adiquiridos da American Type Culture Collection (ATCC); além dos fungos filamentosos Mucor circinelloides CBS 277.49 e NRRL 3631, e Botrytis cinerea UCA 992 e 2100, os quais foram empregados nos experimentos realizados na Universidade de Cádiz (Espanha).

As linhagens de bactérias do trato gastrintestinal (probióticas) Lactobacillus acidophilus (FERM FD DVS LA-5 ${ }^{\circledR}-$ Probio-Tec $^{\mathrm{TM}}$ ), Bifidobacterium sp. (FERM FD DVS BB $12^{\circledR}$ - Probio-Tec ${ }^{\mathrm{TM}}$ ) e cultura mista que contém Lactobacillus acidophilus, Bifidobacterium sp. e Streptococcus salivarius subsp. thermophilus (FERM F DVS 
ABT-4) foram adquiridas da empresa CHR Hansen, a qual fornece às indústrias alimentícias culturas de micro-organismos para a produção de alimentos funcionais probióticos. A bactéria Escherichia coli ATCC 25922 foi obtida da American Type Culture Collection (ATCC).

\subsection{Manutenção dos fungos filamentosos e das bactérias do trato} gastrointestinal

Para confecção dos estoques das culturas fúngicas, todos os fungos utilizados neste estudo foram cultivados separadamente em Placas de Petri contendo meio malte, durante sete dias em incubadora com ventilação (B.O.D.), a $30^{\circ} \mathrm{C}$. Após esse período, três discos de micélio-ágar de aproximadamente $6 \mathrm{~mm}$ de diâmetro, obtidos com auxílio de um tubo de transferência $\left(\right.$ Sigma $^{\circledR}$ ) esterilizado, foram transferidos para criotubos esterilizados contendo $2 \mathrm{~mL}$ de água destilada autoclavada. Os criotubos foram então vedados com filme plástico e mantidos sob refrigeração $\left(4^{\circ} \mathrm{C}\right)$.

As culturas das bactérias probióticas estão sendo mantidas congeladas $\left(-20{ }^{\circ} \mathrm{C}\right)$ em caldo MRS, acrescido de L-cisteína/ $\mathrm{HCl}(0,05 \%)$, contendo $20 \% \mathrm{v} / \mathrm{v}$ de glicerol e $50 \% \mathrm{v} / \mathrm{v}$ de sangue desfibrinado de carneiro (Ebefarma).

A linhagem de E. coli foi mantida congelada $\left(-20^{\circ} \mathrm{C}\right)$ em caldo $\mathrm{MH}$ contendo $40 \% \mathrm{v} / \mathrm{v}$ de glicerol.

\subsection{Produção de esporos e padronização do crescimento dos fungos}

\section{filamentosos}

Inicialmente, os fungos filamentosos foram cultivados em tubos de ensaio contendo diferentes meios de cultura sólidos inclinados: meio aveia-ágar, meio extrato de malte e meio PDA. As culturas foram incubadas por 7 a 15 dias, em B.O.D., a $30{ }^{\circ} \mathrm{C}$. 
Após o término do período de incubação, foram adicionados $5,0 \mathrm{~mL}$ de solução salina esterilizada em cada tubo de ensaio. Em seguida, foi efetuada a contagem do número de esporos das suspensões em câmara de Neubauer (16 quadrantes) e o meio mais adequado para a produção dos esporos de cada fungo foi selecionado.

Em seguida, foi estudada a produção de biomassa em meio pré-fermentativo de Jackson. Para isso, os fungos filamentosos foram reativados, a partir das culturasestoque, em tubos de ensaio contendo o meio de cultura apropriado e de acordo com as condições selecionadas no experimento descrito anteriormente. Após o período de incubação, $10^{6}$ esporos $/ \mathrm{mL}$ de cada fungo foram inoculados em $15 \mathrm{~mL}$ de meio préfermentativo contidos em frascos tipo Erlenmeyer de $125 \mathrm{~mL}$ de capacidade.

As culturas foram desenvolvidas sob agitação constante de $120 \mathrm{rpm}$ e temperatura de $30{ }^{\circ} \mathrm{C}$. O tempo de incubação foi investigado, sendo então possível padronizar o crescimento dos fungos filamentosos no meio pré-fermentativo e verificar o tempo necessário para que cada fungo atingisse a fase estacionária de crescimento. Esse procedimento foi utilizado na investigação do crescimento de todos os fungos filamentosos empregados nos experimentos realizados na Faculdade de Ciências Farmacêuticas de Ribeirão Preto-USP.

\subsection{Padronização do crescimento das bactérias do trato gastrointestinal}

As culturas-estoque foram inicialmente ativadas em caldo MRS, por duas incubações sucessivas por um período de 20 horas a $37{ }^{\circ} \mathrm{C}$, em câmara de anaerobiose (atmosfera de $85 \%$ de nitrogênio, $10 \%$ de dióxido de carbono e 5\% de gás hidrogênio). Em seguida, as culturas foram transferidas para placas de Petri contendo ágar MRS acrescido de L-cisteína/HCL $(0,05 \%)$ e foram incubadas por três dias, sob as mesmas condições. A L-cisteína/HCL foi esterilizada por filtração e depois adicionada ao meio 
de cultura em quantidade para alcançar a concentração de $0,05 \%$, sendo utilizada para reduzir os teores de oxigênio e facilitar o crescimento dos micro-organismos. Para o cultivo de L. acidophilus e da mistura láctica, além da L-cisteína/HCL foram adicionados 33,3\% de glicose, em relação ao peso seco, aos meios de cultura (GODERSKA, NOWAK e CZARNECKI, 2008).

Após o período de três dias, foram preparados inóculos de cada uma das culturas com auxílio de espectrofotômetro calibrado no comprimento de onda de $625 \mathrm{~nm}$. Cada inóculo continha $10^{11} \mathrm{UFC} / \mathrm{mL}$ de caldo MRS. Foi transferido $1 \mathrm{~mL}$ de cada inóculo para $30 \mathrm{~mL}$ de caldo MRS acrescido de L-cisteína/HCL (0,05\%) e, se necessário, 33,3 \% de D-glicose. Assim, o número final de unidades formadoras de colônia presentes no meio de cultura foi de $10^{6} \mathrm{UFC} / \mathrm{mL}$, quantidade que segundo Charteris e colaboradores (1998) representa o número de micro-organismos ativos fisiologicamente no intestino humano de tais bactérias. A incubação foi realizada a $37^{\circ} \mathrm{C}$, em câmara de anaerobiose, sob agitação de 120 rpm. Foram retiradas alíquotas nos tempos de 3, 6, 9, 12, 18, 24, 30, 36, 42, 48, 60 e 72 horas para enumeração das unidades formadoras de colônias (UFC).

Procedimento semelhante foi realizado para a padronização do crescimento da bactéria E. coli. Essa bactéria foi primeiramente reativada em caldo $\mathrm{MH}$, tanto em condições anaeróbias (em câmara de anaerobiose) como em condições aeróbias (em estufa), a $37{ }^{\circ} \mathrm{C}$ e durante 24 horas. Após esse período, as culturas foram transferidas para placas de Petri contendo ágar MH e reincubadas nas condições anaeróbia ou aeróbia, por 24 horas. Em seguida, um inóculo de $10^{6} \mathrm{UFC} / \mathrm{mL}$ foi transferido para Erlenmeyers de $125 \mathrm{~mL}$ de capacidade contendo $30 \mathrm{~mL}$ de caldo $\mathrm{MH}$, e incubado sob condições anaeróbias (agitação em câmara de anaerobiose) e aeróbias (mesa agitadora), a $37{ }^{\circ} \mathrm{C}$ e $120 \mathrm{rpm}$. Foram retiradas alíquotas nos tempos de 3, 6, 9, 12, 18, 24, 30, 36, 42 e 48 horas para enumeração das células viáveis. 
Todos os cultivos, inclusive aqueles realizados em atmosfera anaeróbica, foram incubados sob agitação.

\subsection{Verificação dos efeitos tóxicos dos substratos sobre os micro-organismos}

\section{utilizados}

Para determinar as concentrações de lapachol e seu sal de potássio, atovaquona e isolapachol a serem utilizados nos processos de biotransformação foi adotado o método de microdiluição em microplaca de 96 poços $\left(\operatorname{TPP}^{\circledR}\right)$, para determinação dos valores de concentração inibitória mínima, segundo a metodologia preconizada pelo Clinical and Laboratory Standards Institute (CLSI, 2006; CLSI, 2008; CLSI, 2007).

Os fungos filamentosos foram cultivados previamente em tubos de ensaio contendo $20 \mathrm{~mL}$ de meio malte. Placas de Petri contendo ágar MRS, acrescido de L-cisteína/HCL (0,05\%) e, se necessário, 33,3\% de D-glicose, foram utilizadas para os cultivos das bactérias probióticas. Placas de Petri contendo ágar $\mathrm{MH}$ foram empregadas no cultivo da bactéria E. coli. Todas as culturas foram incubadas sob condições préestabelecidas e utilizadas para a preparação dos inóculos.

Para realização dos ensaios de microdiluição em microplacas tentou-se mimetizar as condições experimentais dos processos de biotransformação no que diz respeito ao meio de cultura e tamanho de inóculo utilizados. Para isso o meio de cultura utilizado no ensaio com as bactérias probióticas foi o caldo MRS acrescido de Lcisteína/HCL (0,05\%) e, se necessário, 33,3\% de D-glicose, enquanto para $E$. coli foi o caldo MH. Para os fungos filamentosos utilizou-se meio Koch's K1 ou Czapek (nos experimentos realizados na Faculdade de Ciências Farmacêuticas de Ribeirão PretoUSP), Czapek Dox ou meio líquido rico (nos experimentos realizados na Universidade de Cádiz, Espanha). O inóculo preparado continha $10^{6}$ esporos $/ \mathrm{mL}$ em todos os casos. 
As concentrações dos substratos testados em todos os casos variaram de 400 a $0,195 \mu \mathrm{g} / \mathrm{mL}$, obtidas por meio de diluição seriada. Para isso, $1 \mathrm{mg}$ de cada substrato foi dissolvido em $125 \mu$ L de DMSO (Synth) sendo essa solução denominada "solução mãe" (8000 $\mu \mathrm{g} / \mathrm{mL})$. Posteriormente, $20 \mu \mathrm{L}$ da "solução mãe" foram diluídos em $80 \mu \mathrm{L}$ do caldo de cultivo utilizado, sendo essa solução denominada "solução 1" (1600 $\mu \mathrm{g} / \mathrm{mL})$. Cada poço da placa de 96 poços foi inicialmente preenchido com $100 \mu \mathrm{L}$ do meio de cultura. Então, $100 \mu \mathrm{L}$ da solução 1 foram colocados no primeiro poço para iniciar a diluição seriada. Depois de proceder com a diluição seriada, foram adicionados em cada poço $80 \mu \mathrm{L}$ do caldo de cultivo e $20 \mu \mathrm{L}$ de inóculo.

Foram feitos controles de esterilidade dos meios de cultivo, de crescimento do inóculo na presença de 5\% de DMSO, de esterilidade dos substratos, de viabilidade do inóculo e também controles positivos, utilizando miconazol (Sigma) para os fungos, penicilina G (Sigma) para as bactérias probióticas e estreptomicina (Sigma) para a bactéria $E$. coli. A concentração dos controles positivos variou de 5,9 a 0,0028 $\mu \mathrm{g} / \mathrm{mL}$.

A solução de penicilina $\mathrm{G}$ foi preparada com $1 \mathrm{mg}$ do antibiótico diluído em $10 \mathrm{~mL}$ de tampão fosfato de potássio $0,07 \mathrm{~mol} / \mathrm{L}, \mathrm{pH}=6,0(2,0 \mathrm{~g}$ de fosfato de potássio dibásico, 8,0 g de fosfato de potássio monobásico, diluídos em $1000 \mathrm{~mL}$ de água destilada). Transferiu-se $1 \mathrm{~mL}$ desta solução para tubo de ensaio contendo $4 \mathrm{~mL}$ do caldo de cultivo. Desta última solução foi retirada uma alíquota de $59 \mu \mathrm{L}$, a qual foi depositada no primeiro orifício da placa de 96 poços, a partir do qual realizou-se a diluição seriada.

A solução de estreptomicina foi preparada com $1 \mathrm{mg}$ do antibiótico diluído em $10 \mathrm{~mL}$ de tampão fosfato de potássio $0,1 \mathrm{~mol} / \mathrm{L}, \mathrm{pH}=7,9(16,73 \mathrm{~g}$ de fosfato de potássio dibásico, 0,523 g de fosfato de potássio monobásico, diluídos em $1000 \mathrm{~mL}$ de água destilada). Transferiu-se $1 \mathrm{~mL}$ desta solução para tubo de ensaio contendo $4 \mathrm{~mL}$ do 
caldo de cultivo. Desta última solução foi retirada uma alíquota de $59 \mu \mathrm{L}$, a qual foi depositada no primeiro orifício da placa de 96 poços, a partir do qual se realizou a diluição seriada.

A solução do antifúngico miconazol foi preparada com $1 \mathrm{mg}$ dissolvido em 750 $\mu \mathrm{L}$ de DMSO. Dessa solução, foram tomados $75 \mu \mathrm{L}$ e adicionados a $4925 \mu \mathrm{L}$ de caldo. Desta última solução foi retirada uma alíquota de $59 \mu \mathrm{L}$, a qual foi depositada no primeiro orifício da placa de 96 poços, a partir do qual se realizou a diluição seriada.

Para facilitar a detecção de crescimento microbiano, utilizou-se como indicador de viabilidade celular $40 \mu \mathrm{L}$ de uma solução aquosa de resazurina (Sigma) a 0,02\% em cada poço.

\subsection{Avaliação da influência das condições de cultivo nas reações de} biotransformação do lapachol e do seu sal de potássio com fungos filamentosos

Os experimentos foram iniciados utilizando-se os fungos A. brasiliensis, $M$. rouxii, C. lunata, A. ochraceus e $R$. stolonifer, na avaliação da biotransformação do lapachol e seu sal de potássio. Tais experimentos tiveram como objetivo avaliar a influência que certos parâmetros exercem no metabolismo dos substratos. Assim, os parâmetros avaliados foram: utilização de dois meios de cultivo diferentes (Koch's K1 e Czapek), diversos tempo de incubação (alíquotas retiradas diariamente durante dez dias) e substratos com diferente solubilidade no meio de cultura (lapachol e seu sal de potássio).

As massas miceliais obtidas das culturas desenvolvidas no meio préfermentativo foram filtradas, lavadas com água destilada esterilizada e transferidas para dois diferentes meios fermentativos, Czapek e Koch's K1. Os substratos foram imediatamente adicionados ao meio Koch's K1. Quando as biotransformações foram 
realizadas em meio Czapek, o substrato foi adicionado somente após 24 horas. As culturas foram desenvolvidas a $30{ }^{\circ} \mathrm{C}$, sob agitação constante de $120 \mathrm{rpm}$, por 10 dias. O volume de meio de cultura utilizado foi de $30 \mathrm{~mL}$ contidos em Erlenmeyers de $125 \mathrm{~mL}$ de capacidade. Alíquotas foram retiradas a cada 24 horas, com aferição do $\mathrm{pH}$ por meio de tiras de papel indicador de $\mathrm{pH}$ (Merck).

Em seguida, novos experimentos, utilizando-se das condições mais promissoras, foram realizados para avaliação da biotransformação do lapachol pelos fungos $C$. echinulata var. elegans e C. elegans.

O fungo $A$. brasiliensis foi também empregado na realização de outros testes acerca da obtenção de derivados utilizando-se o lapachol. Nestes experimentos, utilizaram-se de condições idênticas às relatadas anteriormente. A única diferença foi a utilização do meio Koch's K1 modificado.

Durante a realização de estágio no exterior, a biotransformação do lapachol foi avaliada utilizando-se duas linhagens de M. circinelloides, separadas e também em cultura mista, além de duas linhagens de B. cinerea. Foram utilizados frascos tipo Erlenmeyer de $250 \mathrm{~mL}$ de capacidade contendo $100 \mathrm{~mL}$ de meio de cultivo, os quais foram incubados a $30{ }^{\circ} \mathrm{C}$, sob agitação de $120 \mathrm{rpm}$ e durante cinco dias. Foram empregadas também garrafas para incubação estática contendo $150 \mathrm{~mL}$ de meio de cultura, incubadas a $30^{\circ} \mathrm{C}$ por cinco dias. Alíquotas diárias foram retiradas, tanto dos Erlenmeyers, quanto das garrafas.

Culturas de B. cinerea UCA 992 e 2100 foram previamente desenvolvidas em placas de Petri contendo ágar tomate até produzirem esporos (20 dias). Transcorrido esse tempo, os esporos foram recolhidos e contados com auxílio de câmara de Neubauer. Assim, foi possível adicionar $10^{6}$ esporos $/ \mathrm{mL}$ a cada recipiente onde as 
biotransformações foram realizadas. O meio de cultura utilizado nas biotransformações por B. cinerea foi Czapek Dox.

As duas linhagens de $M$. circinelloides foram repicadas, separadamente e também em mistura, em placas de Petri contendo ágar rico, incubadas a $30^{\circ} \mathrm{C}$, durante cinco dias. Os frascos tipo Erlenmeyer e as garrafas incubadas com $M$. circinelloides continham meio de cultura líquido rico e a quantidade de esporos inoculada foi de $10^{6}$ esporos $/ \mathrm{mL}$.

Em todos os experimentos foram feitos controles com os meios de cultura inoculados, sem as substâncias a serem biotransformadas, com os meios de cultura não inoculados contendo as substâncias, bem como com os meios de cultura sem as substâncias, mas com o solvente utilizado para solubilizar as mesmas (DMSO).

Além disso, o lapachol foi adicionado aos meios fermentativos dissolvido em 2\% de DMSO, enquanto o sal de potássio do lapachol não necessitou de tal prédissolução. Ambos substratos foram adicionados em quantidade de acordo com os resultados dos testes de toxicidade (item 3.7, página 29). A influência das variáveis no processo de biotransformação foi verificada mediante avaliação dos perfis químicos das frações em acetato de etila obtidas a partir de partições líquido-líquido dos caldos das culturas.

Ao término dos processos de biotransformação, as massas miceliais resultantes foram lavadas com água destilada, pesadas e submetidas à extração com acetato de etila. O objetivo desse procedimento foi verificar se o substrato foi interiorizados e/ou metabolizado no interior na célula fúngica. 


\subsection{Avaliação da influência das condições de cultivo nas reações de} biotransformação do lapachol e do seu sal de potássio com bactérias do trato gastrointestinal

As culturas isoladas de bactérias lácticas do trato gastrintestinal (L. acidophilus, Bifidobacterium sp. e cultura mista contendo L. acidophilus, Bifidobacterium sp. e $S$. salivarius subesp. thermophilus) foram desenvolvidas em $30 \mathrm{~mL}$ de caldo MRS, acrescido de L-cisteína/HCl (0,05\%) e D-glicose, se necessário, em Erlenmeyers de 125 $\mathrm{mL}$ de capacidade. As culturas foram incubadas a $37^{\circ} \mathrm{C}$, sob agitação constante de 120 rpm, durante 24 horas, em câmara de anaerobiose. Alíquotas foram retiradas a cada 12 horas.

As biotransformações utilizando E. coli foram realizadas utilizando $30 \mathrm{~mL}$ de caldo MH contidos em Erlenmeyers de $125 \mathrm{~mL}$ de capacidade. A incubação foi realizada em anaerobiose e aerobiose, a $37{ }^{\circ} \mathrm{C}$, durante 24 horas, com retirada de alíquotas a cada 12 horas.

A adição dos substratos foi realizada após os micro-organismos terem atingido a fase estacionária de crescimento, em quantidade de acordo com os resultados dos testes de toxicidade (item 3.7, página 29). O lapachol foi adicionado aos meios de cultivo dissolvido em DMSO, enquanto o sal de potássio de lapachol não necessitou de tal prédissolução.

Foram feitos controles com os meios de cultura inoculados, sem as substâncias a serem biotransformadas, com os meios de cultura não inoculados contendo as substâncias, bem como com os meios de cultura sem as substâncias, mas com o solvente utilizado para solubilizar as mesmas (DMSO). 
A influência das variáveis no processo de biotransformação foi verificada mediante avaliação dos perfis químicos das frações em acetato de etila obtidas a partir de partições líquido-líquido dos caldos das culturas.

\subsection{Avaliação da influência das condições de cultivo nas reações de biotransformação do isolapachol e da atovaquona com fungos filamentosos e bactérias do trato gastrointestinal}

Os estudos sobre a biotransformação do isolapachol e atovaquona foram feitos de maneira idêntica aos reportados quando utilizou-se lapachol como substrato (itens 3.8 e 3.9, páginas 31 e 34). Porém, utilizou-se somente as linhagens de fungos filamentosos e bactérias do trato gastrointestinal que apresentaram melhores resultados no metabolismo do lapachol. A escolha do tempo de incubação e meio de cultivo utilizados também foram realizados observando-se os procedimentos mais promissores.

Também utilizou-se aqui o monitoramento do $\mathrm{pH}$ do meio de cultura durante a biotransformação de ambos os substratos. Além disso, as massas miceliais resultantes dos cultivos foram lavadas com água destilada, pesadas e submetidas à extração com acetato de etila.

\subsection{Obtenção das frações dos caldos das culturas dos fungos e bactérias e} dos micélios das culturas dos fungos

Decorrido o período de incubação, os meios fermentativos foram separados das culturas dos fungos filamentosos por filtração sob pressão reduzida e os filtrados obtidos foram submetidos à partição líquido-líquido com acetato de etila, por três vezes consecutivas, para obtenção das frações em acetato de etila. As massas miceliais foram submetidas à extração por maceração com acetato de etila. 
Para obtenção dos extratos das culturas das bactérias, as culturas foram inicialmente centrifugadas durante três minutos a $4000 \mathrm{rpm}$, sob refrigeração de $15{ }^{\circ} \mathrm{C}$. Posteriormente, os sobrenadantes foram submetidos à partição líquido-líquido com acetato de etila, por três vezes consecutivas, para obtenção das frações em acetato de etila.

Todas as frações foram concentradas por evaporação sob vácuo e armazenadas em frascos âmbar sob refrigeração.

\subsection{Avaliação dos perfis químicos das frações obtidas das culturas dos}

\section{fungos filamentosos e das bactérias gastrointestinais}

As frações em acetato de etila, dos controles e dos testes, foram analisadas utilizando-se CLAE, empregando-se coluna cromatográfica analítica de fase reversa Kromasil $\left(\mathrm{C}_{18}, 250,0 \times 4,6 \mathrm{~mm}, \operatorname{Varian}^{\circledR}\right)$ acoplada à pré-coluna com a mesma fase estacionária.

Equipamento da marca Shimadzu foi utilizado para a realização de CLAE. O equipamento é composto por três bombas Shimadzu LC-10AD, detector espectrofotométrico por conjunto de arranjo de diodos UV/VIS Shimadzu SPD-M10A (Fotodiode Array), sistema controlador SCL-10 A $\mathrm{VP}_{\mathrm{VP}}$, conectado a um computador com software Shimadzu Class-VP versão 5.02 e injetor automático (SIL-10AD $\left.{ }_{\mathrm{VP}}\right)$.

Foram utilizadas as seguintes condições cromatográficas: sistema de eluição por gradiente, iniciando com metanol:água 55:45, atingindo $100 \%$ de metanol em 30 minutos e finalizando com metanol:água 55:45 em 35 minutos. A água utilizada foi acidificada com TFA $(0,012 \%)$. A vazão foi de $1,0 \mathrm{~mL} / \mathrm{min}$ e foram injetados $20 \mu \mathrm{L}$ de cada fração na concentração de $1,0 \mathrm{mg} / \mathrm{mL}$, solubilizados na fase móvel inicial. Os cromatogramas foram plotados em comprimento de onda de $251 \mathrm{~nm}$, selecionado após 
varredura de todo o espectro no ultravioleta. As condições cromatográficas utilizadas foram desenvolvidas com base em métodos analíticos pré-desenvolvidos e validados para análise do lapachol em CLAE (STEINERT, KHALAF e RIMPLER, 1995; FONSECA et al., 2004).

\subsection{Biotransformação do lapachol e atovaquona em escala preparativa}

Após análise e comparação dos perfis químicos das frações foi selecionado o tempo de incubação mais promissor, para cada substância e micro-organismo. A biotransformação foi então realizada em escala preparativa, aumentando-se o número de frascos utilizados nas biotransformações, e utilizando as condições descritas nos itens 3.8 e 3.9 (páginas 31 e 34).

\subsection{Isolamento dos produtos de biotransformação}

As frações obtidas da biotransformação do lapachol realizada em escala preparativa foram submetidas à CLAE na modalidade semi-preparativa para isolamento dos derivados majoritários. Para isso, empregou-se coluna cromatográfica semipreparativa de fase reversa $\left(C_{12}, 250,0 \times 10,0 \mathrm{~mm}\right.$, tamanho de partícula $4 \mu \mathrm{m}$, Phenomenex $^{\circledR}$, Synergi MAX-RP 80), acoplada a uma pré-coluna com mesmo material de empacotamento. O sistema de CLAE preparativa $\left(\right.$ Shimadzu $\left.^{\circledR}\right)$ utilizado possui duas bombas LC-6AD, detector UV/VIS SPD-20A, sistema controlador CBM-20A, coletor automático de frações FRC-10A e software LCSolution versão 1.1.

Foram utilizadas as seguintes condições cromatográficas: sistema de eluição por gradiente, iniciando com metanol:água 55:45, atingindo $100 \%$ de metanol em 30 minutos e finalizando com metanol:água 55:45 em 35 minutos. A água utilizada foi 
acidificada com TFA $(0,012 \%)$. A vazão foi de $3,0 \mathrm{~mL} / \mathrm{min}$ e foram injetados $100 \mu \mathrm{L}$ de cada fração na concentração de 2,5 mg/mL, solubilizados na fase móvel inicial.

Para facilitar o isolamento de metabólitos da atovaquona, as frações em acetato de etila obtidas em escala ampliada foram pré-fracionadas utilizando cartuchos de extração em fase sólida (SPE), contendo $500 \mathrm{mg}$ de fase estacionária composta por sílica modificada $\mathrm{C}_{18}$. Em cada cartucho foram adicionados cerca de $50 \mathrm{mg}$ de extrato, o qual foi eluído com 2,5 mL de fase móvel composta por metanol e água, iniciando com $100 \%$ água e chegando a $100 \%$ de metanol com proporção crescente do solvente orgânico de 10 em 10\%. Para auxiliar na eluição da fase móvel foi utilizado um sistema de extração em fase sólida (Visiprep-SPE, Supelco ${ }^{\circledR}$ ).

As frações obtidas após fracionamento por SPE foram selecionadas através dos perfis analíticos em CLAE e, posteriormente, os metabólitos contidos nas mesmas foram isolados com auxílio de CLAE na modalidade semi-preparativa, conforme descrito anteriormente no presente item.

Todas as frações obtidas foram evaporadas em evaporador centrífugo (Speedvacum Savant SPD2010) a $45^{\circ} \mathrm{C}$ durante 24 horas. Todas as substâncias isoladas foram protegidas da luz e armazenadas sob refrigeração.

\subsection{Identificação estrutural dos metabólitos isolados}

Para a obtenção dos espectros de massas em alta resolução utilizou-se o espetrômetro de massas micrOTOF II-ESI-TOF (Bruker Daltonics ${ }^{\circledR}$ ), com nitrogênio como gás de colisão, na temperatura de $200{ }^{\circ} \mathrm{C}$. As amostras foram previamente diluídas em metanol:água na proporção de 1:1, na concentração de $0,02 \mathrm{mg} / \mathrm{mL}$, sendo feitas injeções diretas. Para calibração interna utilizou-se solução de $\mathrm{Na}^{+}$-TFA (ácido trifluoroacético sodiado) a $10 \mathrm{mg} / \mathrm{mL}$. 
Os dados de Ressonância Magnética Nuclear (RMN) de todos os substratos e metabólitos isolados foram adquiridos em tubos Shigemi ${ }^{\circledR}$, em espectrômetro Bruker DRX 500, operado a $500 \mathrm{MHz}$, utilizando como solventes metanol deuterado ( $\left.\mathrm{CD}_{3} \mathrm{OD}\right)$ ou clorofórmio deuterado $\left(\mathrm{CDCl}_{3}\right)$, dependendo da solubilidade de cada amostra. Foram obtidos espectros uni e bidimensionais para todos os derivados. Os processamentos dos espectros foram feitos com auxílio do software MestReNova 6.0.2.

Para os metabólitos que apresentavam centro de assimetria, foi medida a rotação óptica específica $\left([\alpha]_{\mathrm{D}}\right)$, utilizando o polarímetro digital JASCO Dip-370.

Para as substâncias inéditas na literatura, foram obtidos os respectivos espectros de infravermelho, em equipamento IRprestige-21 (Shimadzu) controlado pelo software IRsolution, e ponto de fusão, em equipamento MA381 (Marconi).

\subsection{Ensaios citotóxicos}

Os ensaios citotóxicos do lapachol e de seus metabólitos, bem como da atovaquona e seu metabólito foram feitos em parceria com a Profa. Dra. Raquel Alves dos Santos da Universidade de Franca (UNIFRAN). O método utilizado foi o ensaio colorimétrico de XTT. As linhagens testadas foram a de câncer de mama humano SKBR-3, obtida do banco de células do Rio de Janeiro, e a linhagem de fibroblastos normais humanos GM07492-A (Coriell Cell Repositories, USA). Para isso, as células foram tripsinizadas e semeadas em placa de 96 poços a uma concentração de $4 \times 10^{4}$ células/poço em meio DMEM com HAM-F10 (1:1, v/v) (Sigma-Aldrich) suplementado com $10 \%$ de soro fetal bovino (Life Technologies). Após 24 horas de incubação a $37^{\circ} \mathrm{C}$ $\left(\mathrm{CO}_{2} 5 \%\right)$, as culturas de células foram tratadas com diferentes concentrações do lapachol, atovaquona ou seus metabólitos, dissolvidos em DMSO (1\%) em concentrações que variaram de 50 a $400 \mu \mathrm{M}$, sendo a cultura novamente incubada por 
mais 24 horas. Em seguida, a viabilidade das células foi avaliada com o Kit de Proliferação Celular II (Roche) de acordo com as instruções do fabricante. A viabilidade celular foi expressa como a percentagem do controle negativo. Doxorrubicina (Sigma, pureza $>98 \%$ ) a $4 \mu \mathrm{M}$ foi utilizada como o controle positivo. Os ensaios foram feitos em duplicata, sendo repetidos por três vezes. Os resultados foram analisados com auxílio do GraphPad Sigma (3.1) e dados segundo seus valores de $\mathrm{IC}_{50}(\mu \mathrm{M})$. 


\section{RESULTADOS E DISCUSSÕES}

\subsection{Substratos utilizados nas reações de biotransformação}

Anteriormente à utilização dos substratos nos experimentos de biotransformação, precedeu-se a obtenção de seus dados físico-químicos e espectroscópicos a fim de possibilitar as caracterizações estruturais e verificações acerca das purezas, bem como o conhecimento sobre as variáveis que influenciariam os processos de biotransformação.

\section{- Lapachol}

A seguir, apresenta-se a estrutura química (Figura 11), nome químico, fórmula molecular, massa molecular exata, tempo de retenção em CLAE-DAD nas condições cromatográficas descritas no item 3.12 (página 36) e algumas propriedades físicoquímicas (pKa e logP, dados calculados), obtidas a partir do banco de dados SciFinder ou em referência mencionada, do lapachol.

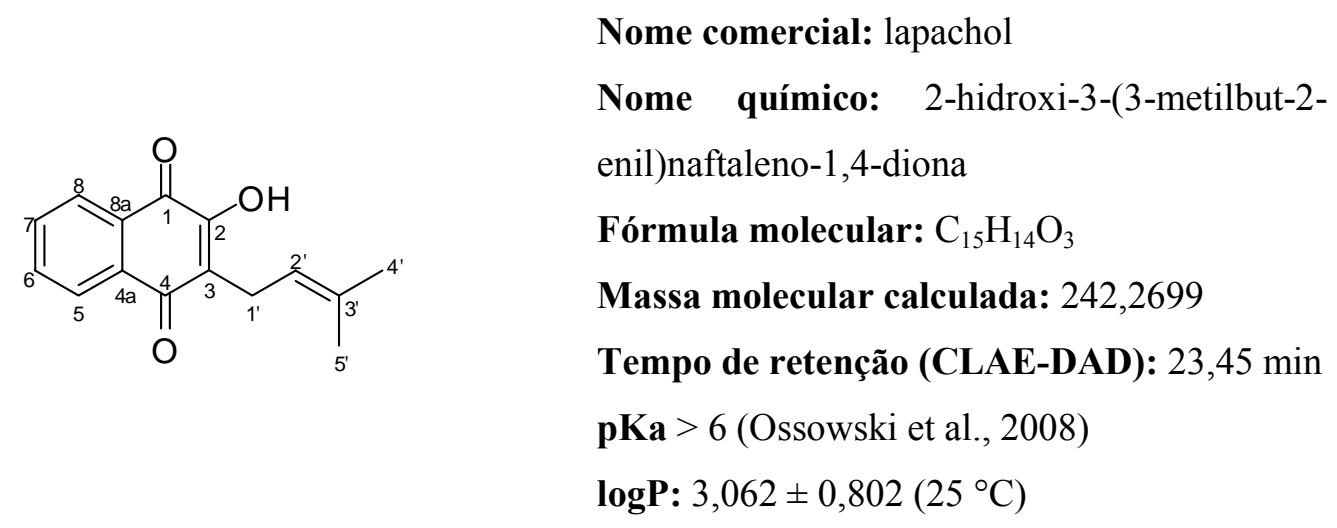

Figura 11. Estrutura química, nome químico, fórmula molecular, massa molecular exata, tempo de retenção em CLAE-DAD e algumas propriedades físicoquímicas do lapachol.

O perfil cromatográfico do lapachol obtido de acordo com as condições descritas no item 3.12 (página 36) está apresentado na Figura 12A e seu espectro de absorção no ultravioleta na Figura 12B. 

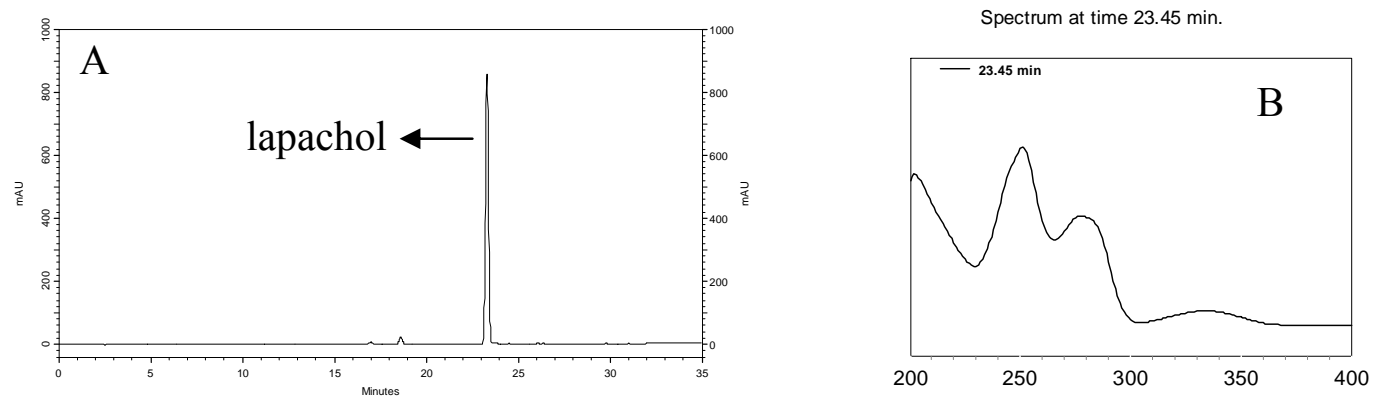

Figura 12. Cromatograma do lapachol (A), tempo de retenção 23,45 minutos, e seu espectro de absorção no ultravioleta (B).

Os dados de $\mathrm{RMN}$ de ${ }^{1} \mathrm{H}$ e ${ }^{13} \mathrm{C}$ do lapachol estão apresentados na Tabela 2. Todos os dados de RMN estão de acordo com o descrito para a molécula do lapachol por Oliveira e colaboradores (2002).

Tabela 2. Dados de $\mathrm{RMN}$ de ${ }^{1} \mathrm{H}(500 \mathrm{MHz})$ e ${ }^{13} \mathrm{C}(125 \mathrm{MHz})$, em $\mathrm{CDOD}_{3}$ do lapachol, $\delta=$ ppm, e comparação com os da literatura (500 e $125 \mathrm{MHz})$.

\begin{tabular}{ccc|cc}
\hline & lapachol & \multicolumn{3}{c}{ OLIVEIRA et al., 2002 $\left(\mathrm{CDCl}_{3}\right)$} \\
\hline Posição & $\boldsymbol{\delta}_{\mathbf{H}}$ multiplicidade $(\boldsymbol{J}$ em Hz) & $\boldsymbol{\delta}_{\mathbf{C}}$ tipo & $\boldsymbol{\delta}_{\mathbf{H}}$ multiplicidade & $\boldsymbol{\delta}_{\mathbf{C}}$ \\
\hline 1 & - & $182,5 \mathrm{C}$ & - & 181,7 \\
2 & - & $156,2 \mathrm{C}$ & - & 152,7 \\
3 & - & $124,6 \mathrm{C}$ & - & 123,5 \\
4 & - & $186,2 \mathrm{C}$ & - & 184,5 \\
5 & $8,02 m$ & $127,0 \mathrm{CH}$ & $8,07 d$ & 126,7 \\
6 & $7,73 m$ & $135,4 \mathrm{CH}$ & $7,70 t$ & 134,8 \\
7 & $7,73 m$ & $133,7 \mathrm{CH}$ & $7,62 t$ & 132,8 \\
8 & $8,02 m$ & $126,7 \mathrm{CH}$ & $8,02 d$ & 126,0 \\
$8 \mathrm{a}$ & - & $131,5 \mathrm{C}$ & - & 129,4 \\
$4 \mathrm{a}$ & - & $134,0 \mathrm{C}$ & - & 132,9 \\
1 & $3,24 d(7,3)$ & $23,2 \mathrm{CH} 2$ & $3,27 d$ & 22,4 \\
2 & $5,17 t(7,3)$ & $121,6 \mathrm{CH}$ & $5,17 t$ & 119,7 \\
3, & - & $134,0 \mathrm{C}$ & - & 133,8 \\
4 & $1,77 s$ & $18,0 \mathrm{CH}$ & $1,75 s$ & 17,9 \\
5 & $1,66 s$ & $25,9 \mathrm{CH}_{3}$ & $1,64 s$ & 25,7 \\
\hline
\end{tabular}

\section{- Isolapachol}

A seguir, apresenta-se a estrutura química (Figura 13), nome químico, fórmula molecular, massa molecular exata, tempo de retenção em CLAE-DAD nas condições 
cromatográficas descritas no item 3.12 (página 36) e algumas propriedades físicoquímicas (pKa e $\log \mathrm{P}$, dados calculados), obtidas a partir do banco de dados SciFinder ou em referência mencionada, do isolapachol.

Nome comercial: isolapachol<smiles>CC(C)/C=C/C1=C(O)C(=O)c2ccccc2C1=O</smiles>

O perfil cromatográfico do isolapachol obtido de acordo com as condições descritas no item 3.12 (página 36) está apresentado na Figura 14A e seu espectro de absorção no ultravioleta na Figura 14B.
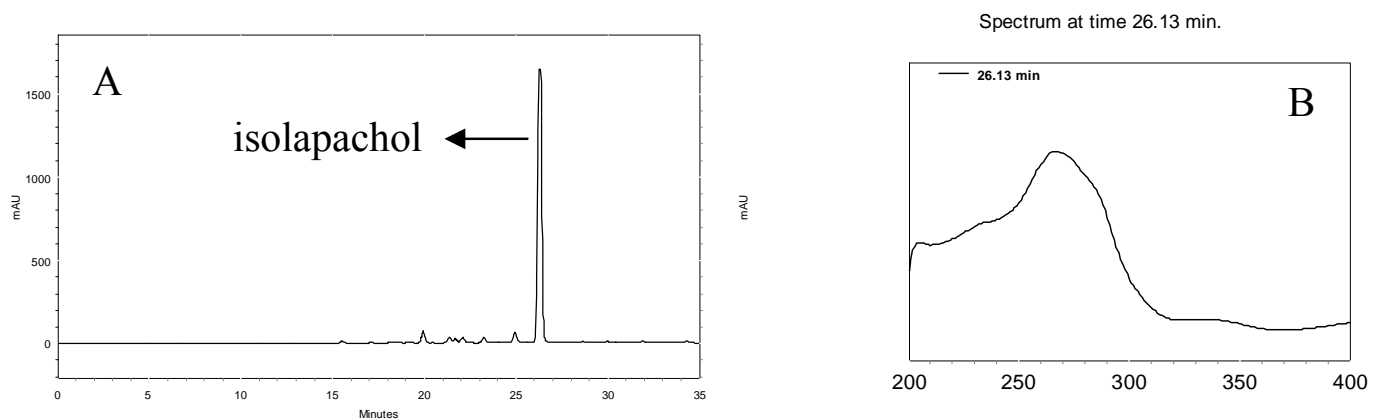

Figura 14. Cromatograma do isolapachol (A), tempo de retenção 26,13 minutos, e seu espectro de absorção no ultravioleta (B).

Na Tabela 2 estão apresentados os dados de RMN de ${ }^{1} \mathrm{He}{ }^{13} \mathrm{C}$ do isolapachol. 
Tabela 3. Dados de $\mathrm{RMN}$ de ${ }^{1} \mathrm{H}(500 \mathrm{MHz})$ e ${ }^{13} \mathrm{C}(125 \mathrm{MHz})$, em $\mathrm{CDCl}_{3}$ do isolapachol, $\delta=$ ppm.

\begin{tabular}{ccc}
\hline Posição & $\boldsymbol{\delta}_{\mathbf{H}}$ multiplicidade $(\boldsymbol{J}$ em Hz) & $\boldsymbol{\delta}_{\mathbf{C}}$ tipo \\
\hline 1 & - & $182,6 \mathrm{C}$ \\
2 & - & $149,0 \mathrm{C}$ \\
3 & - & $119,6 \mathrm{C}$ \\
4 & - & $186,0 \mathrm{C}$ \\
5 & $8,01 \mathrm{~m}$ & $127,4 \mathrm{CH}$ \\
6 & $7,71 \mathrm{~m}$ & $135,6 \mathrm{CH}$ \\
7 & $7,71 \mathrm{~m}$ & $134,0 \mathrm{CH}$ \\
8 & $8,01 \mathrm{~m}$ & $126,6 \mathrm{CH}$ \\
$8 \mathrm{a}$ & - & $131,6 \mathrm{C}$ \\
$4 \mathrm{a}$ & - & $131,6 \mathrm{C}$ \\
1 & $6,56 d(16,2)$ & $117,1 \mathrm{CH}$ \\
2, & $6,98 d d(7,3 ; 16,2)$ & $149,0 \mathrm{CH}$ \\
3, & $2,44 m$ & $34,6 \mathrm{CH}$ \\
4 & $1,07 d(6,7)$ & $22,8 \mathrm{CH}$ \\
5, & $1,07 d(6,7)$ & $22,8 \mathrm{CH} \mathrm{CH}_{3}$ \\
\hline
\end{tabular}

A magnitude da constante de acoplamento vicinal entre os prótons trans $(E)$ entre si de uma ligação dupla normalmente é maior que aquela entre os prótons $\operatorname{cis}(Z)$, sendo de aproximadamente $16 \mathrm{~Hz}$ em trans e de $10 \mathrm{~Hz}$ em cis (PAVIA et al., 2010). Portanto, analisando-se as constantes de acoplamento existentes entre H-1' e H-2' ( $J=$ 16,2 Hz), conclui-se que o isolapachol utilizado no presente estudo possui configuração relativa do tipo $E$.

\section{- Atovaquona}

A seguir, apresenta-se a estrutura química (Figura 15), nome químico, fórmula molecular, massa molecular exata, tempo de retenção em CLAE-DAD nas condições cromatográficas descritas no item 3.12 (página 36) e algumas propriedades físicoquímicas (pKa e logP, dados calculados), obtidas a partir do banco de dados SciFinder, da atovaquona. 
Nome comercial: atovaquona

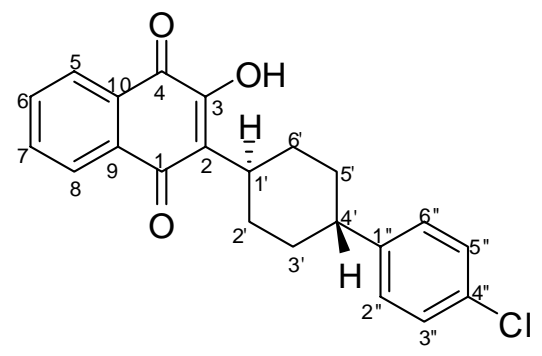

Nome químico: 2-((1'R,4'R)-4'-(4'”-

clorofenil)ciclohexil)-3-hidroxinaftaleno-1,4diona

Fórmula molecular: $\mathrm{C}_{22} \mathrm{H}_{19} \mathrm{ClO}_{3}$

Massa molecular calculada: 366,1023

Tempo de retenção (CLAE-DAD): 32,83 min

pKa: $5,01 \pm 0.10\left(25^{\circ} \mathrm{C}\right)$

$\log \mathrm{P}: 6,465 \pm 0,729\left(25^{\circ} \mathrm{C}\right)$

Figura 15. Estrutura química, nome químico, fórmula molecular, massa molecular exata, tempo de retenção em CLAE-DAD e algumas propriedades físicoquímicas da atovaquona.

O perfil cromatográfico da atovaquona obtido de acordo com as condições descritas no item 3.12 (página 36) está apresentado na Figura $16^{\mathrm{a}}$ e seu espectro de absorção no ultravioleta na Figura 16B.
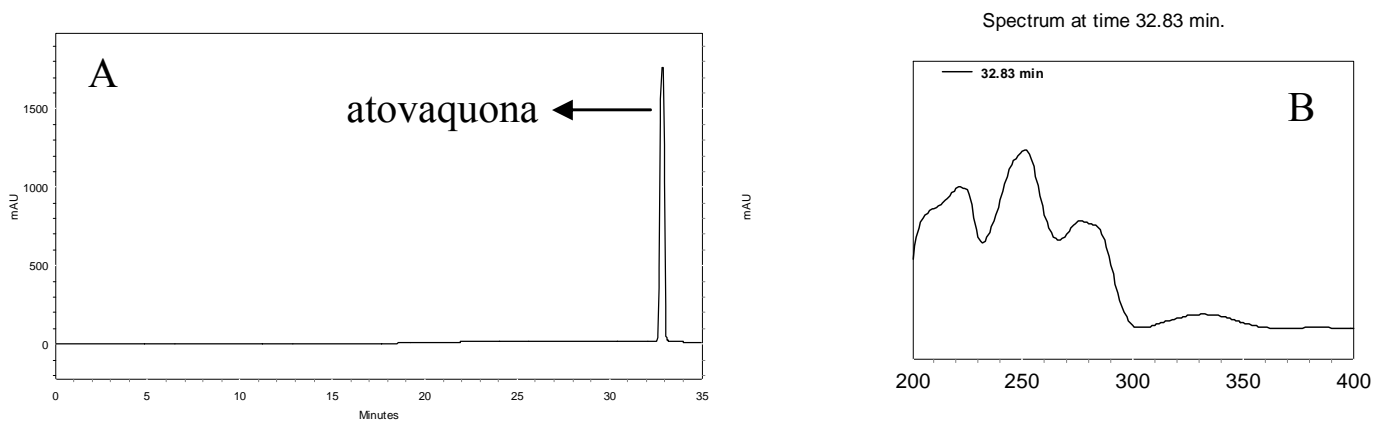

Figura 16. Cromatograma da atovaquona (A), tempo de retenção 32,83 minutos, e seu espectro de absorção no ultravioleta (B).

Os dados de $\mathrm{RMN}$ de ${ }^{1} \mathrm{He}$ e ${ }^{13} \mathrm{C}$ da atovaquona estão apresentados na Tabela 4. 
Tabela 4. Dados de $\mathrm{RMN}$ de ${ }^{1} \mathrm{H}(500 \mathrm{MHz})$ e ${ }^{13} \mathrm{C}(125 \mathrm{MHz})$, em $\mathrm{CDCl}_{3}$ da atovaquona, $\delta=$ ppm.

\begin{tabular}{|c|c|c|}
\hline Posição & $\delta^{1} \mathbf{H}$ (multiplicidade, $J$ em Hz) & $\delta^{13} \mathrm{C}$ \\
\hline 1 & - & 183,1 \\
\hline 2 & - & 133,3 \\
\hline 3 & - & 152,7 \\
\hline 4 & - & 183,1 \\
\hline 5 & $8,04 m$ & 127,2 \\
\hline 6 & $7,71 \mathrm{~m}$ & 134,0 \\
\hline 7 & $7,77 m$ & 135,7 \\
\hline 8 & $8,04 \mathrm{~m}$ & 127,2 \\
\hline 9 & - & 131,3 \\
\hline 10 & - & 131,3 \\
\hline 1 ' & $2,35 m$ & 30,5 \\
\hline 2 ' & 1,$60 ; 1,96 m$ & 35,9 \\
\hline $3^{\prime}$ & 1,$29 ; 1,74 m$ & 31,0 \\
\hline $4^{\prime}$ & $2,63 \mathrm{~m}$ & 44,6 \\
\hline 5 , & 1,$75 ; 2,31 \mathrm{~m}$ & 30,6 \\
\hline 6 ' & 1,$57 ; 1,93 m$ & 35,9 \\
\hline $1 ”$ & - & 147,7 \\
\hline $2 "$ & $7,26 m$ & 129,8 \\
\hline $3 "$ & $7,26 m$ & 129,8 \\
\hline $4 ”$ & - & 132,3 \\
\hline $5 "$ & $7,26 m$ & 129,8 \\
\hline 6" & $7,26 m$ & 129,8 \\
\hline
\end{tabular}

4.2 Padronização do crescimento dos micro-organismos utilizados nas

\section{biotransformações}

Sabe-se que a produção da maioria das enzimas dos micro-organismos ocorre na fase estacionária de crescimento, estando geralmente associada às condições estressantes (ROBINSON, SINGH e NIGAM, 2001). Baseando-se nisso, e levando-se em consideração que, na fase estacionária, tais enzimas possuem menor especificidade pelos substratos, optou-se pela adição de lapachol, de seu sal de potássio, de isolapachol ou de atovaquona, aos meios de cultura, apenas quando os micro-organismos atingissem a fase estacionária. A utilização de um meio pré-fermentativo rico em nutrientes, como 
o de Jackson, permitiu a adaptação (fase lag) do micro-organismo ao novo ambiente de forma rápida e favoreceu também a fase exponencial do crescimento. Assim, procedeuse à padronização do crescimento dos micro-organismos utilizados nos processos de biotransformação com o intuito de determinar o tempo necessário para que cada um deles chegasse à fase estacionária nas condições utilizadas.

\section{- Fungos filamentosos}

De acordo com o descrito no item 3.5 (página 26), foi determinado o melhor meio de cultivo para a produção dos esporos dos fungos filamentosos e o tempo de incubação mais adequado. Assim, concluiu-se que os fungos deveriam ser inicialmente inoculados, para reativação, em meio malte, durante sete dias e a $30^{\circ} \mathrm{C}$.

Em seguida, as curvas de crescimento dos micro-organismos no meio préfermentativo de Jackson foram construídas. Dessa forma, cada fungo foi mantido por diferentes períodos em meio pré-fermentativo até ultrapassar sua fase de adaptação e de crescimento (fase log). Uma vez no início da fase estacionária, as massas miceliais resultantes foram transferidas para um meio pobre em nutrientes e o substrato foi adicionado. A determinação do período de tempo necessário para que cada fungo chegasse à fase estacionária (Tabela 5) foi realizada por meio de pesagens diárias das massas miceliais secas.

Tabela 5. Tempo que cada micro-organismo necessitou para adentrar a fase estacionária de crescimento.

\begin{tabular}{cc}
\hline Fungo filamentoso & Tempo (horas) \\
\hline Aspergillus brasiliensis & 24 \\
Mucor rouxii & 48 \\
Aspergillus ochraceus & 48 \\
Rhizopus stolonifer & 24 \\
Cunninghamella echinulata var. elegans & 48 \\
Cunninghamella elegans & 48 \\
Curvularia lunata & 48 \\
\hline
\end{tabular}




\section{- Bactérias intestinais}

A padronização do crescimento das bactérias intestinais utilizadas no presente estudo, descrita no item 3.6 (página 27), teve o mesmo objetivo que quando realizada para os fungos filamentosos: determinar o início da fase estacionária.

Na Figura 17 estão apresentadas as curvas de crescimento das bactérias intestinais e na Tabela 6 o período necessário para que cada uma dessas bactérias atingisse a fase estacionária.

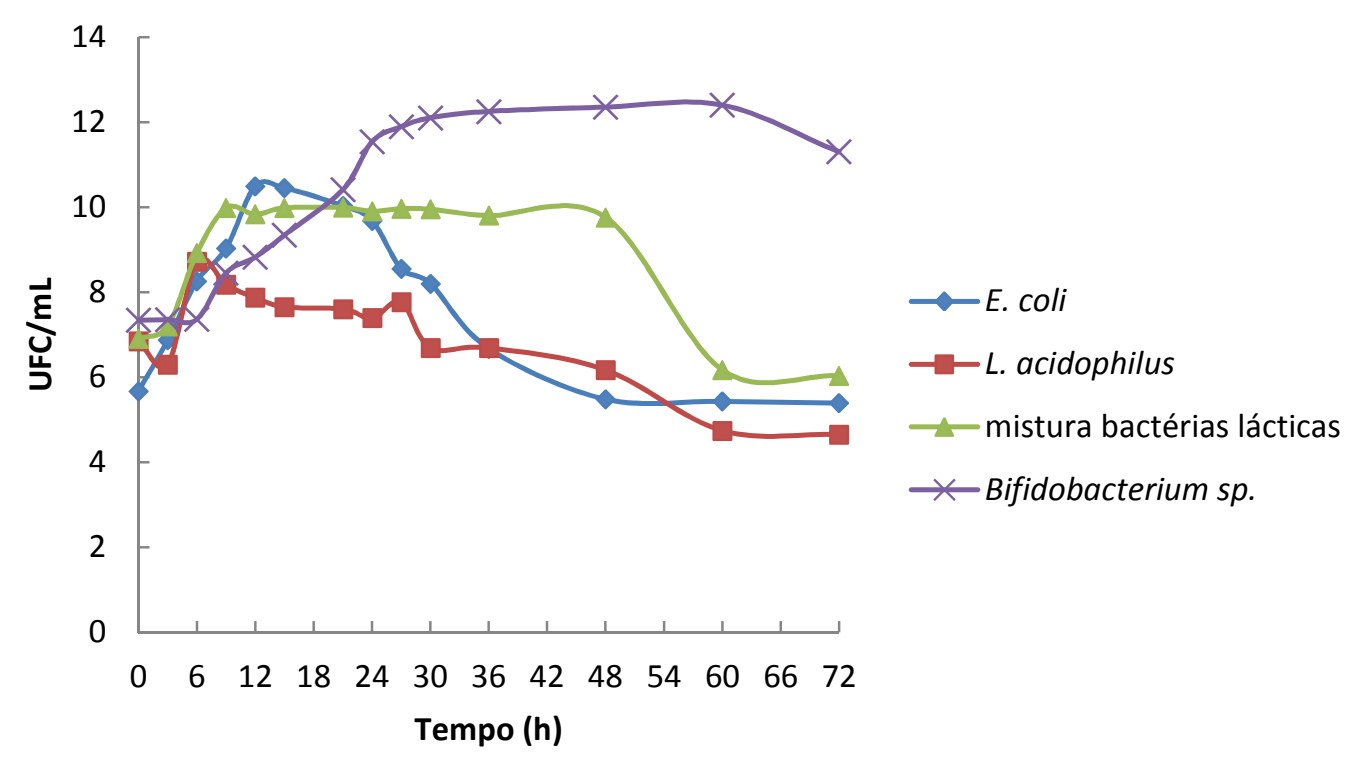

Figura 17. Curva de crescimento das bactérias intestinais.

Tabela 6. Tempo que cada bactéria intestinal necessitou para adentrar a fase estacionária de crescimento.

\begin{tabular}{cc}
\hline Bactéria intestinal & $\begin{array}{c}\text { Tempo } \\
\text { (horas) }\end{array}$ \\
\hline Bifidobacterium sp. & 36 \\
Lactobacillus acidophilus & 12 \\
Cultura mista que contém Lactobacillus acidophilus, Bifidobacterium sp. e & 18 \\
Streptococcus salivarius subsp. thermophilus & 12 \\
Escherichia coli & \\
\hline
\end{tabular}


No caso das bactérias, após atingirem a fase estacionária, o meio de cultura não foi alterado. Cada substrato foi adicionado no mesmo meio de cultura (MRS), no qual as bactérias já se encontravam depois de decorrido o tempo de acordo com a Tabela 6 .

\subsection{Verificação dos efeitos tóxicos dos substratos sobre os micro-organismos}

\section{utilizados nas biotransformações}

A toxicidade dos substratos frente aos micro-organismos utilizados no presente estudo foi determinada segundo a técnica de microdiluição em caldo para determinação da concentração inibitória mínima, descrita no item 3.7 (página 29). A utilização de grandes concentrações de substratos acarreta maior rendimento na obtenção dos metabólitos, porém se utilizadas concentrações tóxicas, pode ocorrer inibição do crescimento dos micro-organismos e, consequentemente, comprometimento da produção enzimática (HAHN et al., 2013). Dessa forma, esse ensaio teve por objetivo determinar a concentração máxima de substrato que poderia ser adicionada aos meios de cultivos sem apresentar toxicidade para os micro-organismos.

Os ensaios de toxicidade, quando realizados na Faculdade de Ciências Farmacêuticas de Ribeirão Preto-USP, mostraram que todos os substratos apresentaram valores de concentração inibitória mínima, frente aos fungos filamentosos e às bactérias intestinais, maiores que $400 \mu \mathrm{g} / \mathrm{mL}$. Já que o volume de meio de cultura utilizado nas reações de biotransformação foi de $30 \mathrm{~mL}$, optou-se por adicionar a cada frasco tipo Erlenmeyer $3 \mathrm{mg}(300 \mu \mathrm{g}$ de substrato/mL de meio de cultura) de cada substrato solubilizado, quando necessário, em DMSO.

Quando o mesmo ensaio foi realizado utilizando-se os micro-organismos avaliados na Universidade de Cádiz (Espanha), verificou-se que concentrações de lapachol superiores a $100 \mu \mathrm{g} / \mathrm{mL}$ eram tóxicas. 
Em relação aos controles positivos utilizados (penicilina, estreptomicina e miconazol), a menor concentração utilizada $(0,195 \mu \mathrm{g} / \mathrm{mL})$ foi capaz de inibir o crescimento de todos os micro-organismos.

\subsection{Estudos sobre a biotransformação do lapachol e do seu sal de potássio} por fungos filamentosos de diferentes gêneros

Os experimentos sobre a biotransformação do lapachol e do seu sal de potássio foram iniciados utilizando-se diferentes fungos filamentosos: A. brasiliensis, $A$. ochraceus, R. stolonifer, M. rouxii e C. lunata, com o objetivo de verificar se as diferentes linhagens seriam capazes de metabolizar de forma diferente os substratos.

Os processos de biotransformação podem ser amplamente afetados pelas propriedades físico-químicas dos substratos, ou seja, se a biodisponibilidade do substrato no meio reacional for prejudicada por problemas de solubilidade, isto pode constituir um fator limitante do processo (WANG et al., 2009). Por esta razão, nos estudos sobre a biotransformação do lapachol utilizou-se também seu sal de potássio, solúvel em meio aquoso.

Além dessas duas variáveis, a espécie de fungo utilizada e a solubilidade do substrato no meio aquoso, dois outros fatores foram avaliados quanto à capacidade de interferir na produção dos metabólitos: composição do meio de cultura e tempo de incubação.

Sabe-se que as reações observadas nos processos de biotransformação variam não só com a linhagem do micro-organismo utilizada, mas também com as condições de cultivo. Muitas enzimas requerem metais coordenados, tais como ferro e níquel, os quais podem ser fornecidos através do enriquecimento do meio de cultura. Por outro lado, a presença ou ausência desses metais pode conduzir a formação de diferentes 
produtos (SINGER, CROWLEY e THOMPSON, 2003). Neste sentido, pode-se citar como exemplo a hidroxilação de um sesquiterpeno por Mucor plumbeus, na qual a redução da quantidade de ferro no meio de cultura fez com que a reação de hidroxilação pré-observada fosse acompanhada pela epoxidação de uma ligação dupla exocíclica (COLLINS et al., 2002).

Dessa forma, o lapachol e seu sal de potássio foram incubados durante 10 dias (com retirada de alíquotas diárias), em dois meios de cultura diferentes (Koch's K1 e Czapek) e com todos os fungos filamentosos descritos anteriormente.

Todas as alíquotas foram submetidas à partição líquido-líquido com acetato de etila e as frações obtidas foram analisadas por CLAE, como descrito no item 3.12 (página 36). As análises dos perfis químicos apresentados pelas frações em acetato de etila possibilitaram inferir as seguintes constatações:

1. Ocorreram variações na produção dos metabólitos quando diferentes linhagens de fungos filamentosos foram utilizadas;

2. Nas primeiras 24 horas de contato entre fungo e substrato, já apareceram os metabólitos;

3. Não houve produção de diferentes metabólitos no decorrer dos nove dias de incubação, e a concentração dos produtos também não variou, considerando como referência as concentrações detectadas nas primeiras 24 horas;

4. Não houve diferença qualitativa ou quantitativa na produção dos metabólitos quando o substrato utilizado foi o lapachol ou seu sal de potássio;

5. Também não houve diferença no perfil metabólico quando o meio de cultura foi alterado.

Nas Figuras 18, 19, 20, 21 e 22 estão apresentados os cromatogramas das frações em acetato de etila obtidas dos caldos das culturas após 24 horas de incubação, 
utilizando-se lapachol como substrato, em meio de cultura Koch's K1, com os diferentes fungos filamentosos. Juntamente, estão apresentados os respectivos controles, resultantes da incubação do meio de cultura com o fungo, sem lapachol. Pôde-se, portanto verificar quais os picos que correspondiam aos metabólitos e quais eram devidos aos componentes do meio de cultura ou aos metabólitos secundários produzidos por cada um dos micro-organismos.
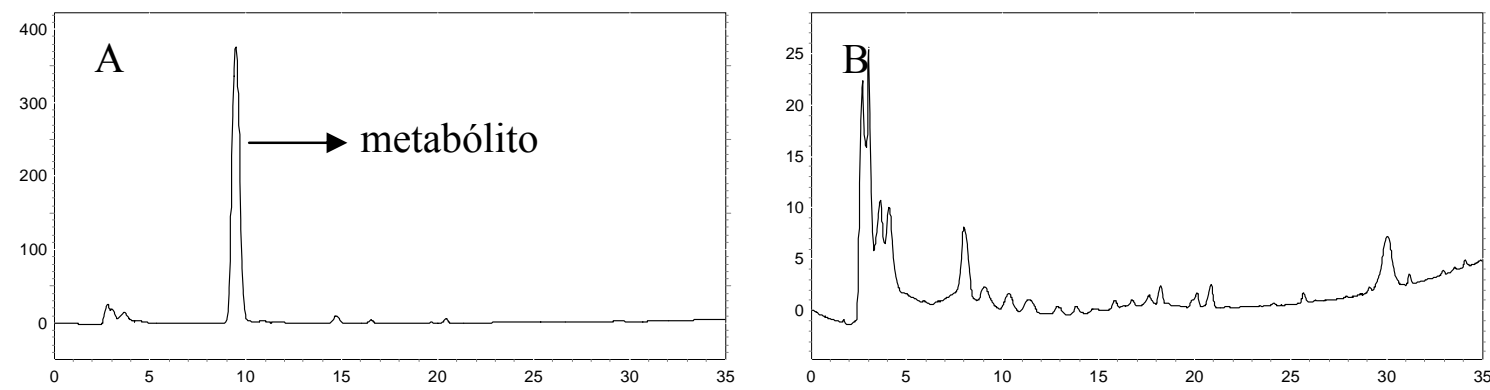

Figura 18. Cromatogramas das frações em acetato de etila dos cultivos de $A$. brasiliensis com (A) e sem lapachol (B).
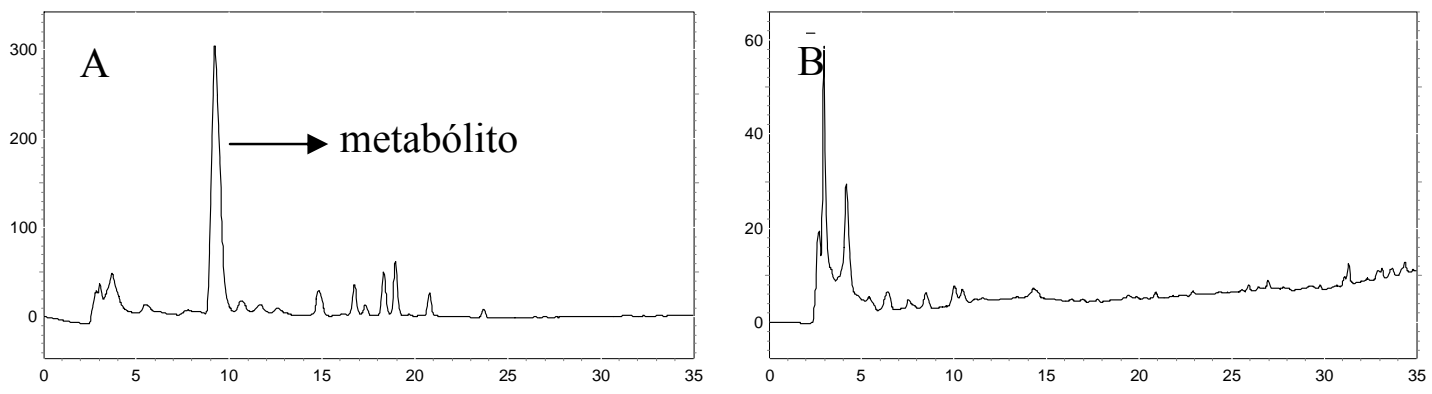

Figura 19. Cromatogramas das frações em acetato de etila dos cultivos de $M$. rouxii com (A) e sem lapachol (B).
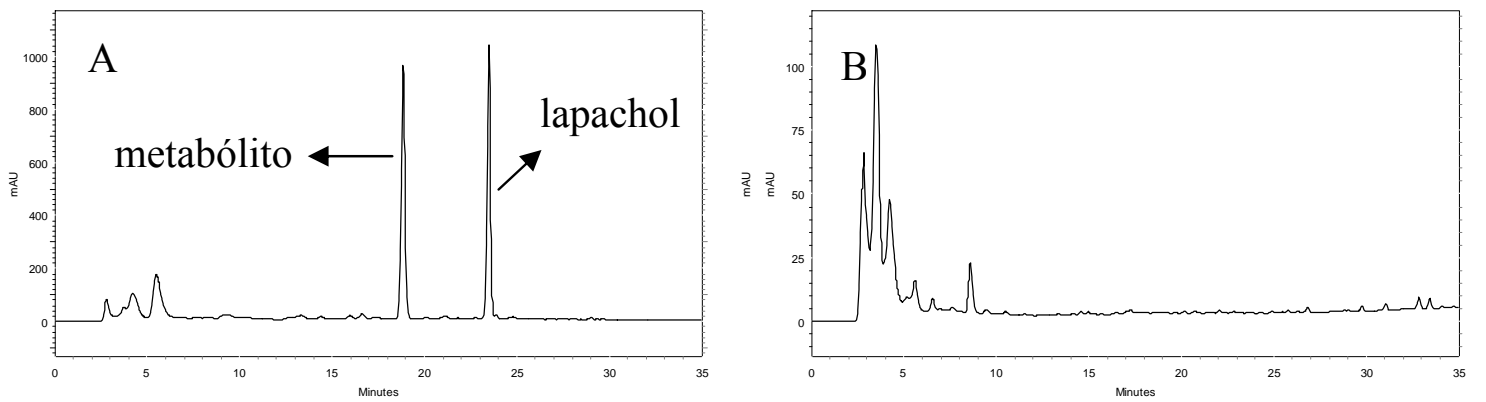

Figura 20. Cromatogramas das frações em acetato de etila dos cultivos de $A$. ochraceus com (A) e sem lapachol (B). 

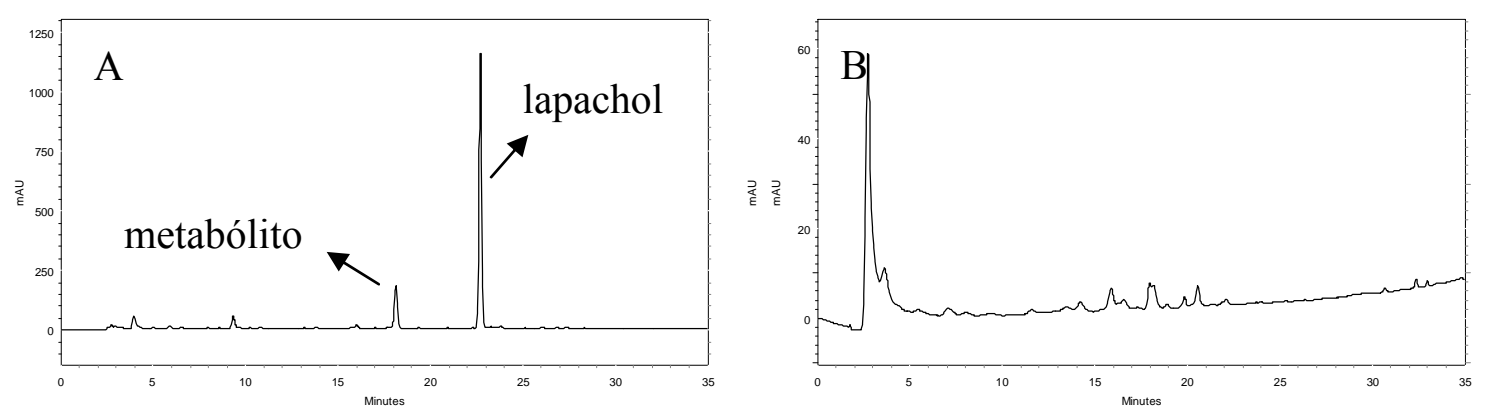

Figura 21. Cromatogramas das frações em acetato de etila dos cultivos de $R$. stolonifer com (A) e sem lapachol (B).
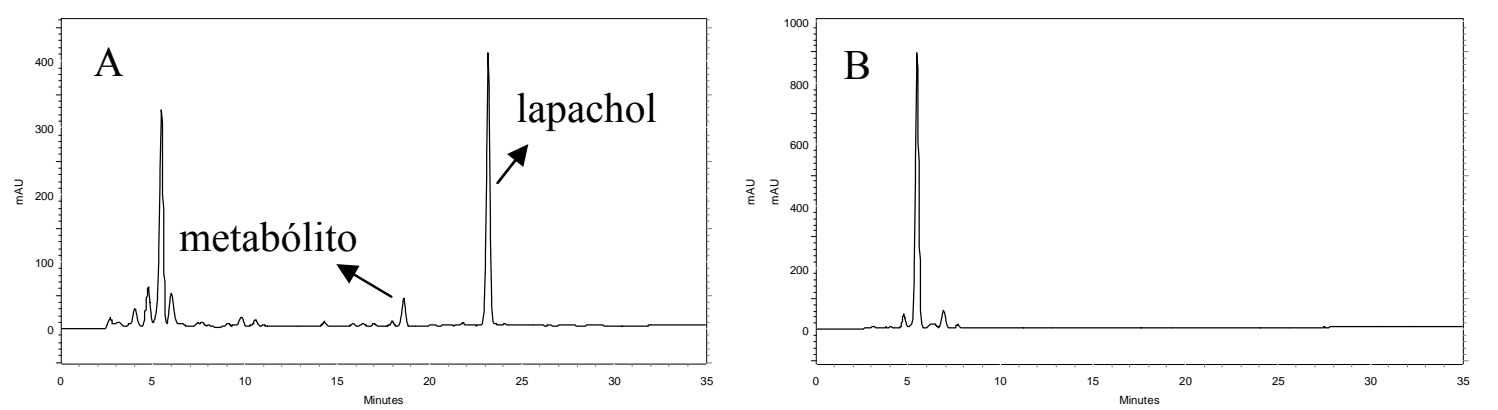

Figura 22. Cromatogramas das frações em acetato de etila dos cultivos de $C$. lunata com (A) e sem lapachol (B).

A análise dos cromatogramas permitiu inferir que os fungos A. brasiliensis (Figura 18) e M. rouxii (Figura 19) biotransformaram completamente o lapachol em metabólitos majoritários com o mesmo tempo de retenção (9,47 minutos). Já os fungos A. ochraceus (Figura 20), R. stolonifer (Figura 21) e C. lunata (Figura 22) biotransformaram o lapachol em outro metabólito com tempo de retenção de 18,85 minutos. Além disso, verificou-se que os fungos A. ochraceus, $R$. stolonifer e C. lunata não apresentaram a mesma eficiência na bioconversão do lapachol que $A$. brasiliensis e M. rouxii, ou seja, o substrato foi totalmente consumido somente nos cultivos $\operatorname{com} A$. brasiliensis e $M$. rouxii. De todos os fungos filamentosos avaliados, C. lunata foi o menos eficiente na metabolização do lapachol. 
Na Figura 23 estão apresentados os espectros de absorção no ultravioleta dos metabólitos majoritários produzidos nas reações de biotransformação pelos diferentes fungos.
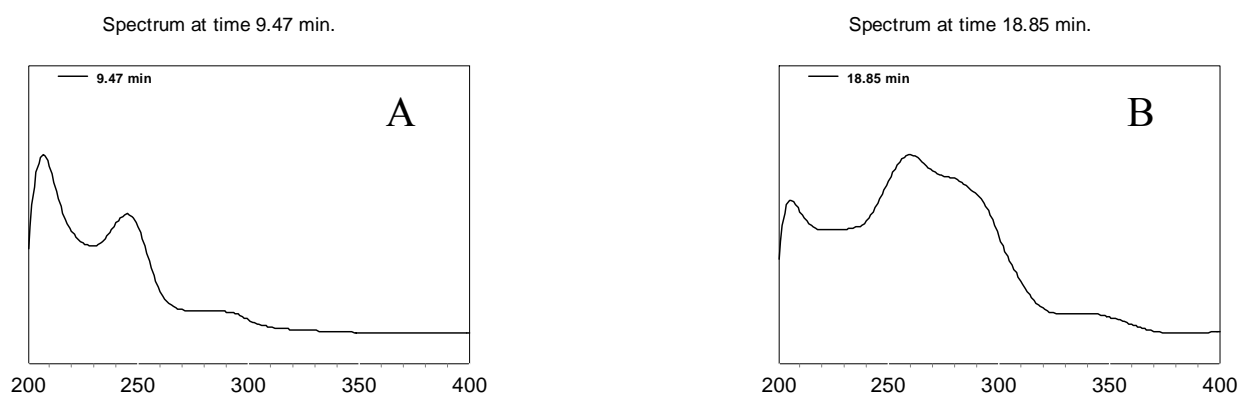

Figura 23. Espectro no ultravioleta dos metabólitos majoritários produzidos a partir da biotransformação do lapachol por: (A) A. brasiliensis e $M$. rouxii, (B) $A$. ochraceus, $R$. stolonifer e $C$. lunata

A verificação de que os metabólitos produzidos por $A$. brasiliensis e $M$. rouxii apresentavam mesmo tempo de retenção e o mesmo espectro no ultravioleta, permitiu inferir que esses dois fungos biotransformaram o lapachol da mesma maneira. O mesmo foi inferido para os metabólitos produzidos por A. ochraceus, $R$. stolonifer e C. lunata. Em seguida foram realizadas coinjeções nas análises por CLAE e a coincidência entre os metabólitos foi confirmada.

Portanto, verificou-se que o lapachol foi biotransformado em dois metabólitos diferentes pelos fungos filamentosos avaliados. A. brasiliensis e A. ochraceus foram os que apresentaram o maior rendimento na produção dos dois metabólitos detectados, fato verificado mediante as análises das áreas dos picos correspondentes aos metabólitos.

A aferição dos valores de $\mathrm{pH}$ das diferentes culturas permitiu verificar que após 24 horas de biotransformação do lapachol, o fungo $A$. brasiliensis foi o único fungo que ocasionou a queda do $\mathrm{pH}$ dos meios de cultivo para 2,0. Em todos os outros experimentos empregando-se os fungos aqui descritos não houve grande alteração do pH do meio de cultura (manteve-se na faixa entre 5,0 e 6,0). Fungos do gênero 
Aspergillus são bons produtores de ácidos orgânicos, fato que está correlacionado a diminuição dos valores de $\mathrm{pH}$ das culturas.

Adicionalmente, as massas miceliais obtidas a partir dos experimentos de biotransformação foram submetidas a processo de extração por maceração em acetato de etila e as frações obtidas foram analisadas por CLAE, de acordo com as condições descritas no item 3.12 (página 36). Os cromatogramas resultantes mostraram que nenhum metabólito foi produzido intracelularmente, tampouco os substratos foram detectados.

\subsection{Estudos sobre a biotransformação do lapachol por fungos filamentosos do gênero Cunninghamella}

As enzimas do citocromo P450 catalisam reações de biotransformação de fase I, atuando no metabolismo de muitos xenobióticos. Sabe-se que as enzimas de diferentes espécies de Cunninghamella agem de forma similar ao metabolismo dos mamíferos (LISOWSKA et al., 2006).

Os experimentos relatados anteriormente revelaram que duas espécies diferentes do gênero Aspergillus, A. brasiliensis e A. ochraceus, foram capazes de biotransformar diferentemente o lapachol. Tal verificação levou-nos a explorar o metabolismo do lapachol por duas espécies diferentes de fungos filamentosos do gênero Cunninghamella: C. echinulata var. elegans e C. elegans.

Para isso, as constatações obtidas anteriormente foram úteis, ou seja, tendo em vista que alterações na solubilidade do substrato, composição do meio de cultura e/ou tempo de incubação não interferiram no perfil metabólico do lapachol, utilizou-se no presente estudo o lapachol como substrato, o meio de cultura Koch's K1 e o tempo de incubação de 120 horas. Os caldos provenientes das culturas foram submetidos à 
partição líquido-líquido com acetato de etila, as frações foram secas e analisadas em CLAE, como descrito no item 3.12 (página 36). Os perfis químicos apresentados pelas frações em acetato de etila estão apresentados nas Figuras a seguir.
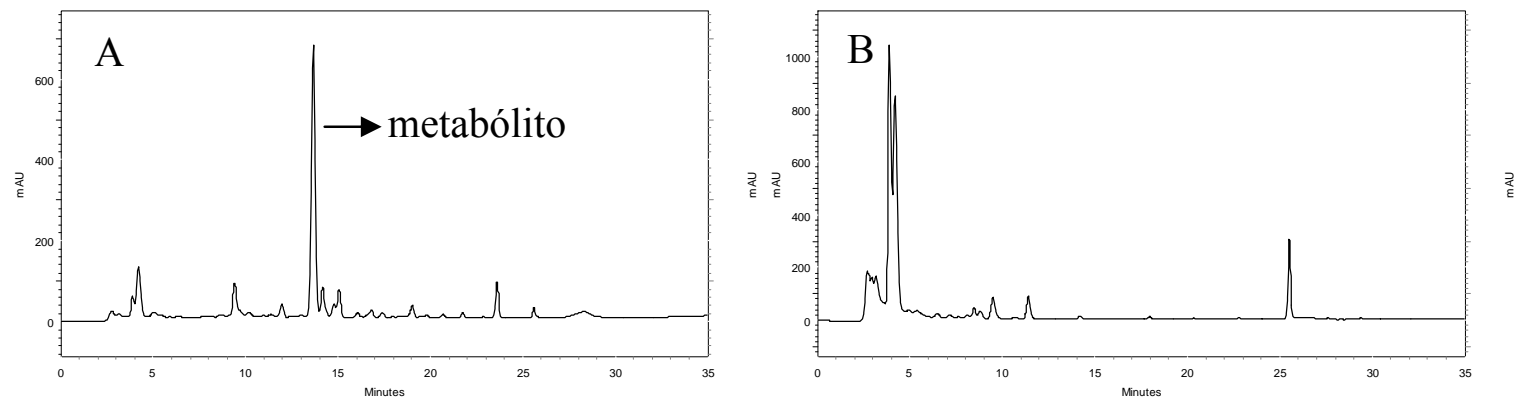

Figura 24. Cromatogramas das frações em acetato de etila dos cultivos de C. echinulata var. elegans com (A) e sem lapachol (B).
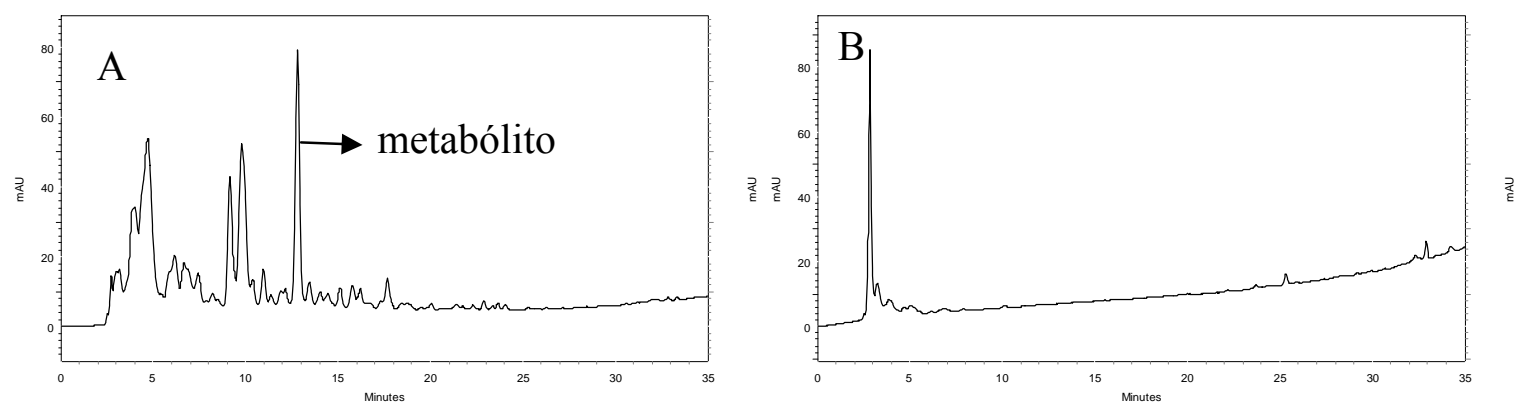

Figura 25. Cromatogramas das frações em acetato de etila dos cultivos de $C$. elegans com (A) e sem lapachol (B).

A análise dos cromatogramas das Figuras $24 \mathrm{~A}$ e $25 \mathrm{~A}$ mostram que um metabólito majoritário (tempo de retenção de 13,67 minutos) foi produzido por ambas as espécies de Cunninghamella avaliadas a partir da completa conversão do lapachol ofertado. A análise dos espectros no ultravioleta (Figura 26) e a realização de coinjeções em análises por CLAE permitiram verificar que o metabólito produzido pelas diferentes espécies tratava-se do mesmo. 


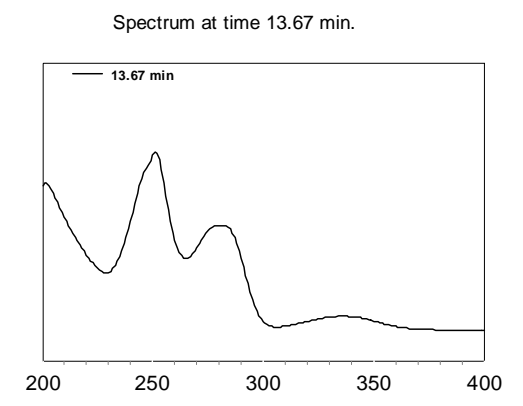

Figura 26. Espectro no ultravioleta do metabólito majoritário produzido por $C$. echinulata var. elegans e C. elegans.

As massas miceliais resultantes foram submetidas à extração com acetato de etila e analisadas por CLAE, de acordo com as condições expostas no item 3.12 (página 36). As análises dos cromatogramas resultantes possibilitaram inferir que o lapachol não foi interiorizado pelos fungos avaliados.

\subsection{Estudos sobre a biotransformação do lapachol por diferentes linhagens}

\section{de Botrytis cinerea e Mucor circinelloides}

Durante a realização de estágio no exterior (Universidade de Cádiz, Espanha), a biotransformação do lapachol foi avaliada empregando-se duas linhagens de $B$. cinerea, UCA992 e 2110, e duas linhagens de M. circinelloides, NRRL 3631 (+) e CBS 277.49 $(-)$

$\mathrm{Na}$ ordem Mucorales estão fungos como Blakeslea trispora e M. circinelloides. Blaskelea trispora produz $\beta$-caroteno e é uma importante fonte comercial deste composto. Quando cultivadas em conjunto, a interação entre os tipos selvagens (+) e (-) desta espécie, linhagens de sexo oposto, aumentam a produção de $\beta$-caroteno e provocam a produção de apocarotenóides como sinalizadores do ciclo sexual (POLAINO et al., 2012). Tendo em vista que a interação entre as linhagens (+) e (-) de fungos da ordem Mucorales pode alterar a produção dos metabólitos, a 
biotransformação do lapachol por $M$. circinelloides foi avaliada empregando-se as linhagens $(+)$ e (-) isoladas e em cultura mista.

Aumento no rendimento da produção dos metabólitos por biotransformação realizada de forma estática foi verificado anteriormente pelo grupo de pesquisa da Universidade de Cádiz. Dessa forma, os estudos aqui descritos foram realizados de forma agitada e também estática.

As biotransformações foram realizadas em meio Czapek ou em meio líquido rico, quando $B$. cinerea ou $M$. circinelloides foram empregados, respectivamente. Alíquotas diárias foram retiradas durante cinco dias e submetidas à partição líquidolíquido com acetato de etila. A análise da produção de metabólitos foi realizada por comparação dos respectivos espectros de RMN de ${ }^{1} \mathrm{H}$. Uma vez no Brasil, as mesmas amostras foram também submetidas à análise por CLAE em cromatógrafo, coluna e método analítico idênticos aos que foram usados nas análises das frações obtidas a partir dos cultivos com os outros micro-organismos (item 3.12, página 36).

Nas Figuras 27 e 28 estão apresentados os cromatogramas da biotransformação do lapachol por B. cinerea UCA992 e 2100, respectivamente, após 24 de incubação e sob agitação. Observou-se o aparecimento de um metabólito majoritário nos cultivos com a linhagem UCA992 (tempo de retenção de 20,51 minutos). O mesmo pico aparece nos cultivos com a linhagem 2100, porém em menor quantidade.
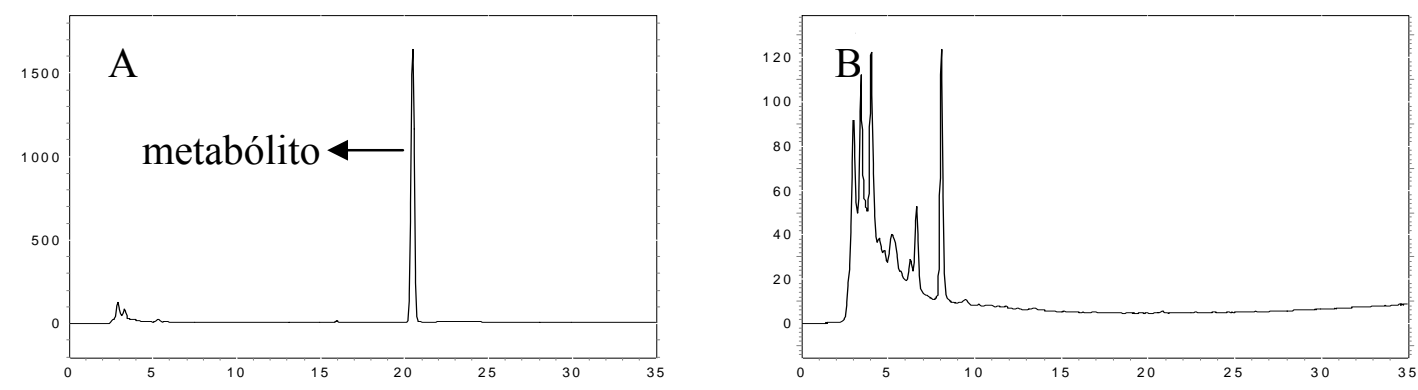

Figura 27. Cromatogramas das frações em acetato de etila dos cultivos de $B$. cinerea UCA992 com (A) e sem lapachol (B). 

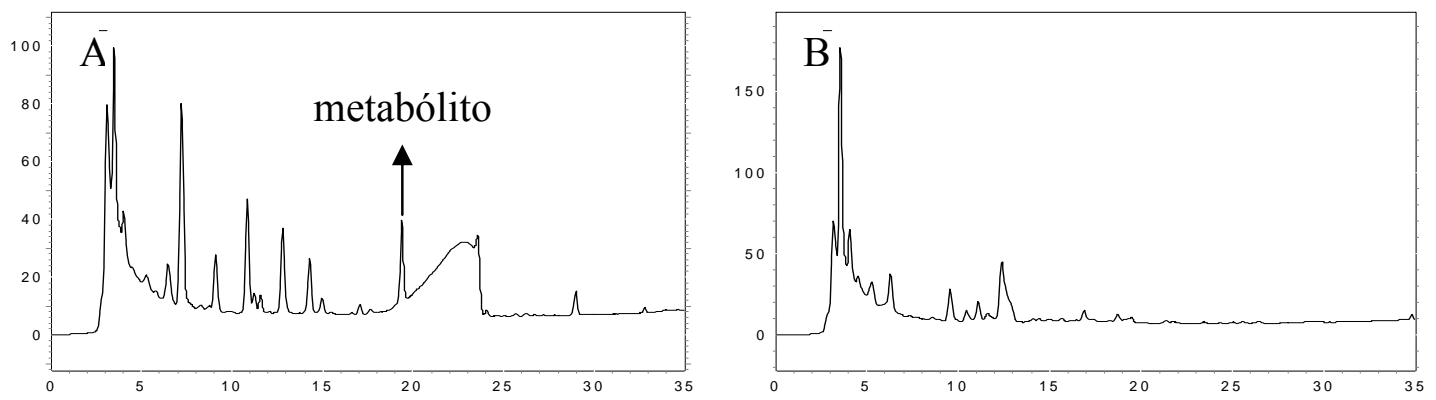

Figura 28. Cromatogramas das frações em acetato de etila dos cultivos de $B$. cinerea 2100 com (A) e sem lapachol (B).

Não ocorreram diferenças nos perfís químicos das frações quando a biotransformação foi realizada de forma agitada ou estática. Além disso, após 24 horas de incubação, os metabólitos foram formados e não houve alterações quali ou quantitativas no decorrer dos dias em que as transformações microbianas catalisadas por B. cinerea foram avaliadas.

Na Figura 29 está apresentado o espectro de absorção no ultravioleta do metabólito produzido por ambas as linhagens de $B$. cinerea.

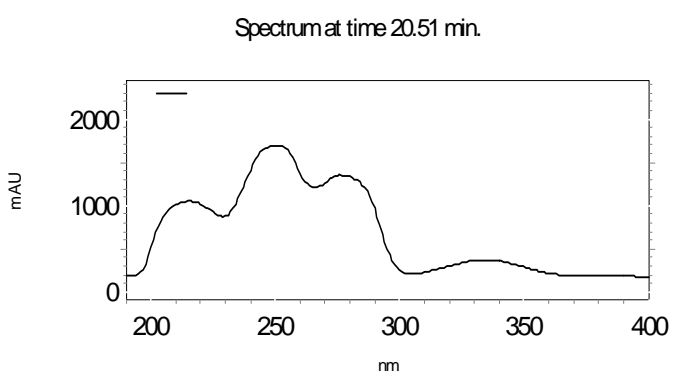

Figura 29. Espectro no ultravioleta do metabólito majoritário produzido por duas linhagens de B. cinerea (UCA992 e 2100).

As diferentes linhagens de $M$. circinelloides biotransformaram o lapachol de forma semelhante quando empregadas separadamente e também quando unidas (Figuras 30, 31 e 32). Ocorreu a formação de um metabólito majoritário (tempo de retenção 
16,67 minutos) em todos os cultivos, com obtenção do menor rendimento com a linhagem (-). Rendimento semelhante foi obtido quando a biotransformação foi realizada pela linhagem $(+)$ ou pelas duas linhagens em culturas mistas. Não ocorreram variações nos perfis metabólicos quando a biotransformação foi realizada de forma agitada ou estática, nem quando o tempo de incubação foi alterado.
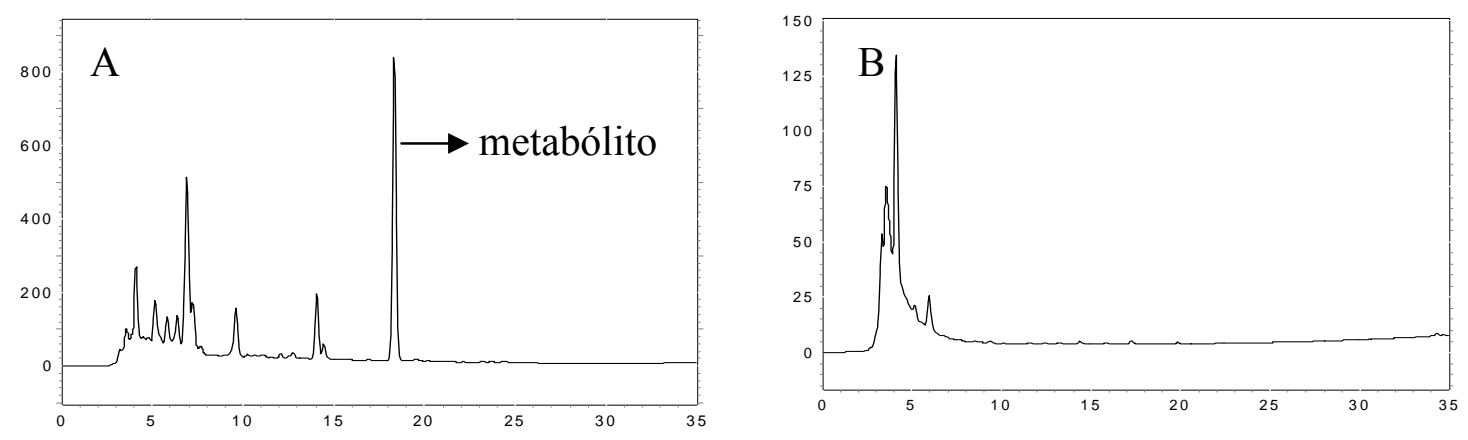

Figura 30. Cromatogramas das frações em acetato de etila dos cultivos de M. circinelloides (+) com (A) e sem lapachol (B).
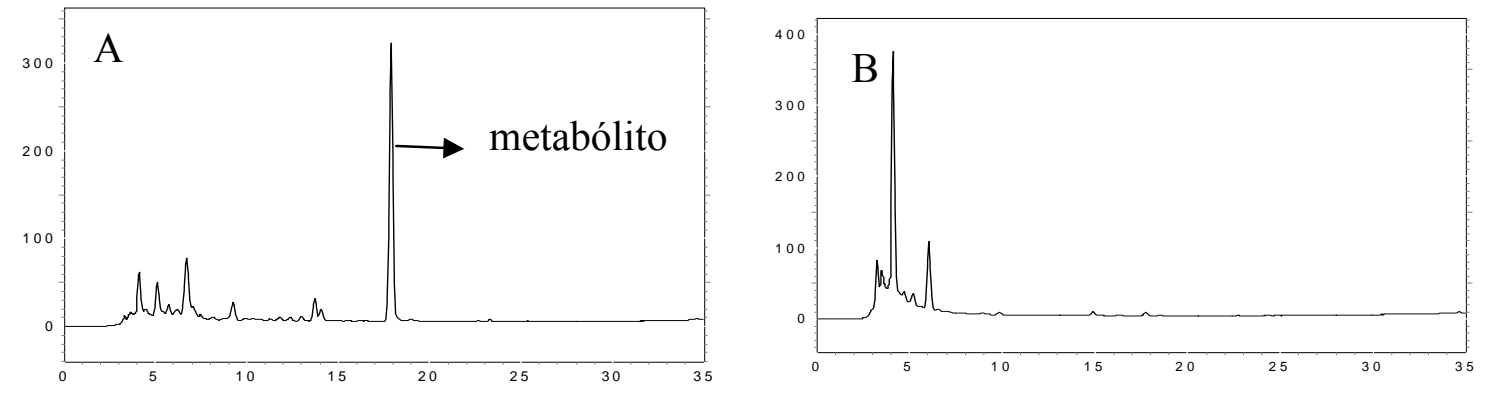

Figura 31. Cromatogramas das frações em acetato de etila dos cultivos de M. circinelloides (-) com (A) e sem lapachol (B).
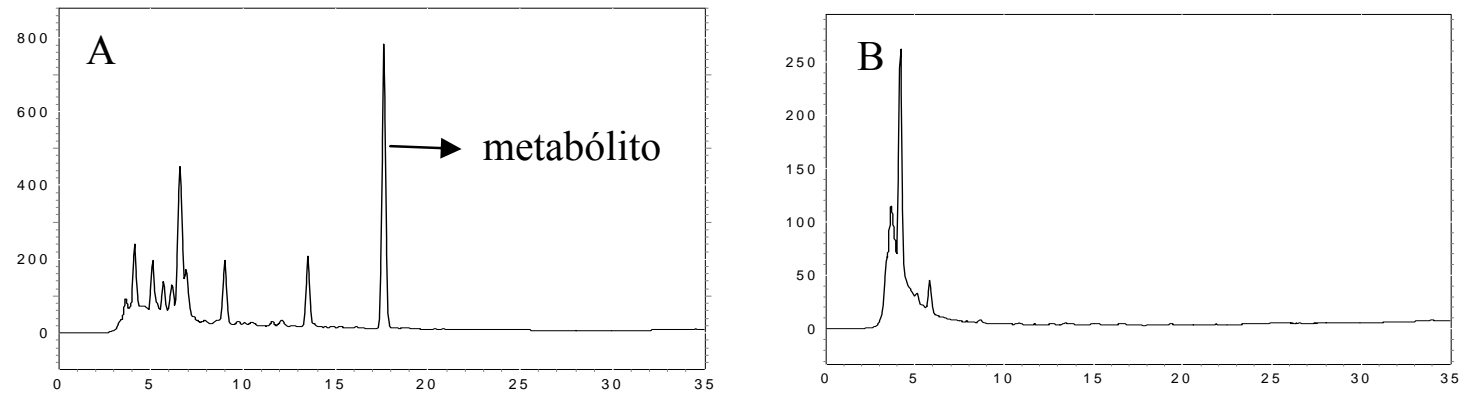

Figura 32. Cromatogramas das frações em acetato de etila dos cultivos de M. circinelloides (+) e (-), em cultura mista, com (A) e sem lapachol (B). 
A comparação dos espectros no ultravioleta dos picos majoritários obtidos nos três cultivos com M. circinelloides e a realização de coinjeções em análises por CLAE permitiram concluir que em todos os cultivos foram produzidos os mesmos metabólitos. Na Figura 33 está apresentado o espectro no ultravioleta desse metabólito.

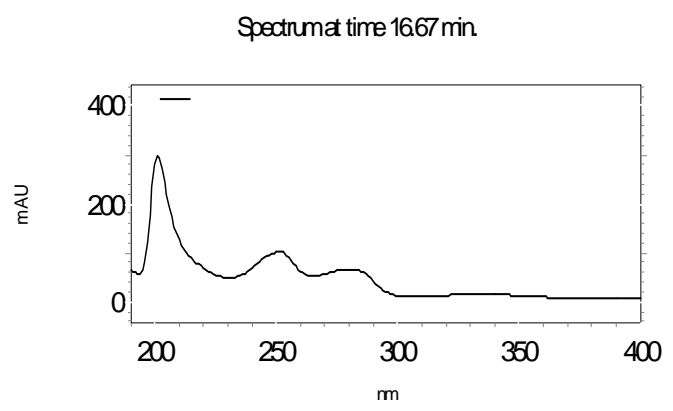

Figura 33. Espectro de absorção no ultravioleta do metabólito majoritário obtido nos cultivos com as duas linhagens de $M$. circinelloides em culturas isoladas e mistas

\subsection{Estudos sobre a biotransformação do lapachol e do seu sal de potássio} por bactérias do trato gastrointestinal

Sabe-se que vários xenobióticos sofrem ação das enzimas produzidas pelas bactérias que colonizam a parede intestinal humana (SOUSA et al., 2008) e que a atividade metabólica apresentada por tais bactérias chega a ser 100 vezes maior que a do fígado (BARROSO et al., 2013). Por esses motivos, algumas bactérias que habitam o trato gastrointestinal humano foram empregadas na biotransformação do lapachol com vistas à predição do metabolismo intestinal que o lapachol poderia sofrer após administração por via oral ou após administração intravenosa, já que fármacos administrados por esta via também podem alcançar o trato gastrointestinal inferior por secreção ou difusão a partir da circulação sistêmica para o lúmen intestinal, ou por terem sido excretados na bile, possivelmente como conjugados, seguindo por um processo conhecido como recirculação êntero-hepática. 
Com o objetivo de determinar as influências que implicam no aparecimento dos metabólitos, as seguintes variáveis foram empregadas: diferentes linhagens de bactérias do trato gastrointestinal (E. coli, L. acidophilus, Bifidobacterium sp. e cultura mista constituída por Bifidobacterium sp., L. acidophilus e S. salivarius subsp. thermophilus), retirada de alíquotas 12 e 24 horas após a adição do substrato e emprego de lapachol e de seu sal de potássio (solúvel no meio de cultura).

A comparação dos perfis químicos das frações em acetato de etila obtidas das culturas após a biotransformação do lapachol e seu sal de potássio pelas bactérias lácticas, L. acidophilus, Bifidobacterium sp. e cultura mista composta por Bifidobacterium sp., L. acidophilus e S. salivarius subsp. thermophilus, mostrou que a produção dos derivados não foi influenciada, quantitativamente nem qualitativamente, pelo tempo de cultivo (12 ou 24 horas após a adição do substrato), nem pela hidrossolubilidade do substrato utilizado. Foi possível notar ainda que as bactérias produziram um derivado, com tempo de retenção de 18,85 minutos, quando em culturas isoladas (Figuras 34 e 35) e outro, com tempo de retenção de 9,47 minutos, quando em culturas mistas (Figura 36). Entre as culturas isoladas, o maior rendimento foi obtido nos cultivos com L. acidophilus (Figura 34).
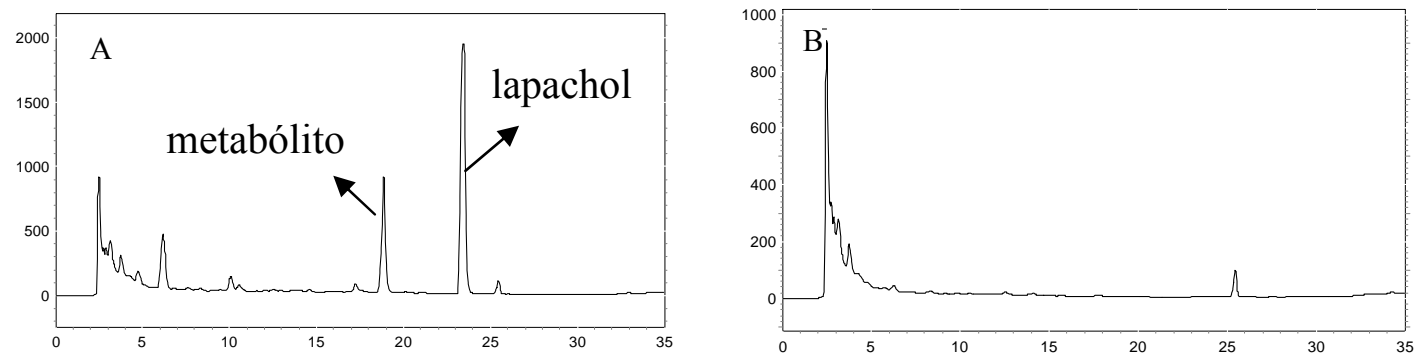

Figura 34. Cromatogramas das frações em acetato de etila dos cultivos de $L$. acidophilus com (A) e sem lapachol (B). 

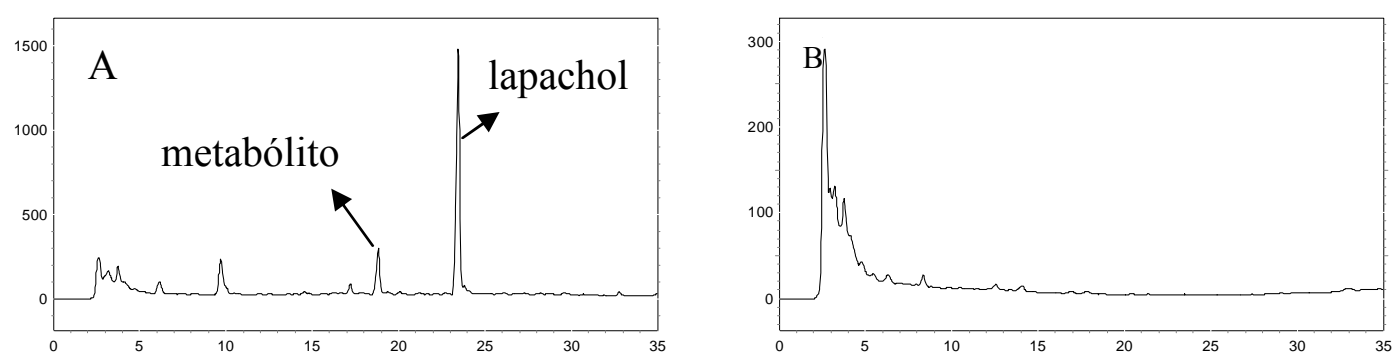

Figura 35. Cromatogramas das frações em acetato de etila dos cultivos de Bifidobacterium sp. com (A) e sem lapachol (B).
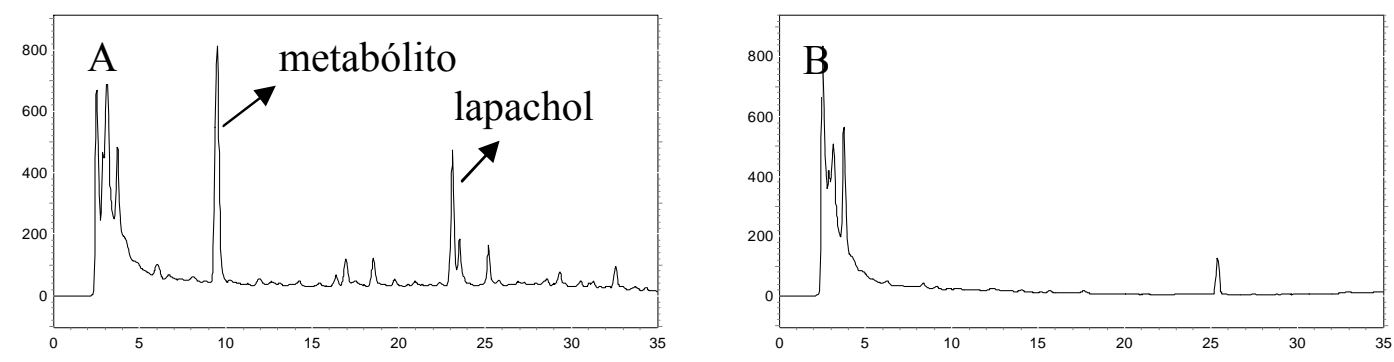

Figura 36. Cromatogramas das frações em acetato de etila dos cultivos de Bifidobacterium sp. e L. acidophilus em cultura mista com $S$. salivarius subsp. thermophilus com (A) e sem lapachol (B).

Na Figura 37 estão apresentados os espectros de absorção no ultravioleta dos metabólitos majoritários obtidos das culturas mistas (Figura 37A) e isoladas (Figura 37B).
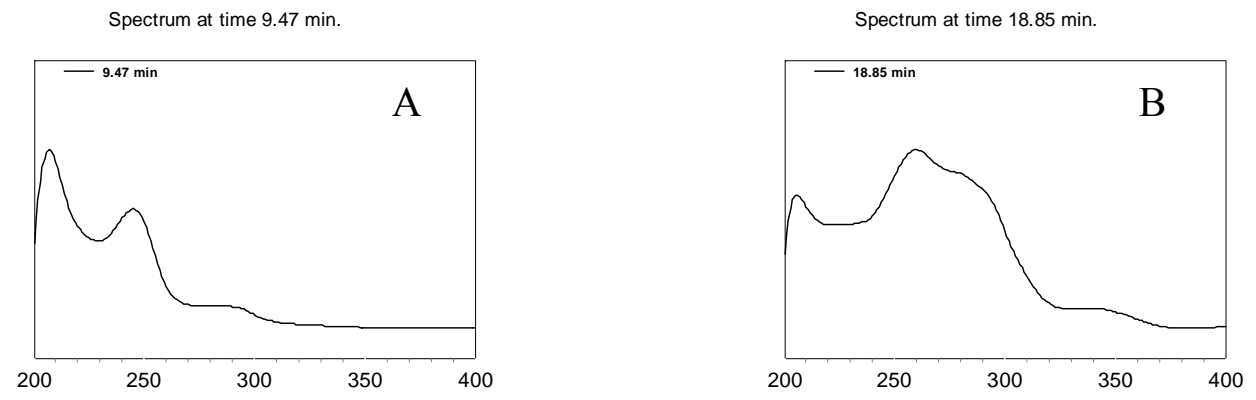

Figura 37. Espectro no ultravioleta dos metabólitos majoritários produzidos a partir da biotransformação do lapachol por: (A) Bifidobacterium sp. e L. acidophilus em cultura mista com S. salivarius subsp. thermophilus;(B) Bifidobacterium sp. e L. acidophilus em culturas isoladas. 
A comparação dos espectros no ultravioleta dos picos majoritários referentes aos metabólitos produzidos por L. acidophilus e Bifidobacterium sp. permitiu inferir que tais bactérias biotransformaram o lapachol da mesma maneira. Tal fato foi confirmado por realização de coinjeções em análises por CLAE.

A bactéria $E$. coli também está presente normalmente no intestino humano (FABBRI et al., 2013), sendo uma bactéria Gram-negativa, anaeróbia facultativa e fermentatora de glicose (KUMAR, ROYMON e IPE, 2013). Assim, E. coli foi também empregada na avaliação da biotransformação do lapachol e do seu sal de potássio, em atmosferas anaeróbia e aeróbia, durante 24 horas, com retirada de alíquotas a cada 12 horas. As frações em acetato de etila provenientes dos caldos das culturas foram analisadas em CLAE, de acordo com as condições expostas no item 3.12 (página 36), e mostraram que tal bactéria não foi capaz de biotransformar o lapachol nem seu sal de potássio, nas condições utilizadas, tanto na presença quanto na ausência de oxigênio, aparecendo somente o pico do substrato inalterado (Figura 38).
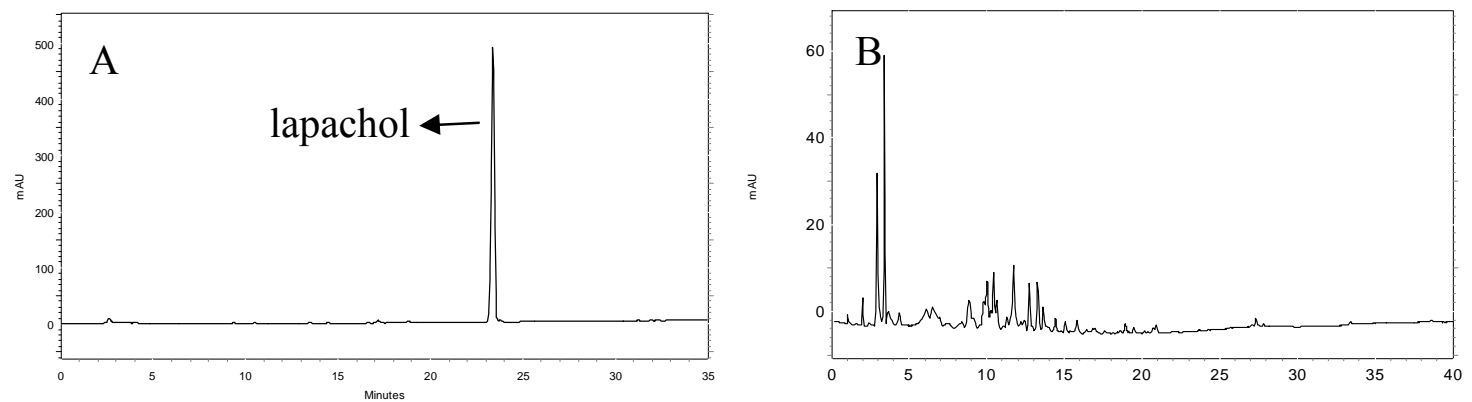

Figura 38. Cromatogramas das frações em acetato de etila dos cultivos de $E$. coli com (A) e sem lapachol (B).

\subsection{Ampliação da escala dos cultivos e isolamento dos metabólitos}

Para isolamento e identificação estrutural dos metabólitos produzidos pelos micro-organismos avaliados, fez-se necessária a ampliação da escala dos cultivos, a qual foi realizada aumentando-se o número de frascos tipo Erlenmeyer empregados, 
incubados sob condições idênticas às utilizadas durante a realização dos cultivos em pequena escala.

Para isso, os micro-organismos e as condições de cultivos considerados como mais promissores, sob o ponto de vista de rendimento e diversidade de metabólitos produzidos, foram selecionados. A Tabela a seguir resume os resultados obtidos nos estudos da biotransformação em pequena escala.

Tabela 7. Metabólitos produzidos nos processos de biotransformação do lapachol por diferentes micro-organismos.

\begin{tabular}{ccc}
\hline Micro-organismo & $\begin{array}{c}\text { Tempo de retenção } \\
\text { do metabólito } \\
\text { majoritário (min) }\end{array}$ & $\begin{array}{c}\text { Código do } \\
\text { metabólito }\end{array}$ \\
\hline A. brasiliensis & 9,47 & $\mathbf{M 1}$ \\
M. rouxii & 9,47 & \\
Cultura mista de bactérias lácticas & 9,47 & $\mathbf{M 2}$ \\
\hline A. ochraceus & 18,85 & \\
R. stolonifer & 18,85 & $\mathbf{M 3}$ \\
C. luneta & 18,85 & $\mathbf{M 4}$ \\
L. acidophilus & 18,85 & \\
Bifidobacterium sp. & 18,85 & $\mathbf{M 5}$ \\
C. echinulata var. elegans & 13,67 & \\
C. elegans & 13,67 & \\
\hline B. cinerea UCA 992 & 20,51 & \\
B. cinerea 2100 & 20,51 & \\
\hline M. circinelloides $(+)$ & 16,67 & \\
M. circinelloides $(-)$ & 16,67 & 16,67 \\
\hline Cultura mista de M.circinelloides $(+) \mathrm{e}(-)$ & &
\end{tabular}

Considerando que os metabólitos que apresentavam o mesmo tempo de retenção foram confirmados como os mesmos após análises de seus espectros de absorção no ultravioleta e realização de coinjeções, a escala de cultivo foi ampliada empregando-se somente aqueles micro-organismos que apresentaram o maior rendimento para a produção de cada um dos metabólitos produzidos. Dessa forma, para a obtenção de M1, M2, M3, M4 e M5, foram escolhidos A. brasiliensis, L. acidophilus, C. echinulata var. elegans, B. cinerea UCA992 e M. circinelloides $(+)$, respectivamente. As culturas foram 
desenvolvidas em condições idênticas às utilizadas no screening inicial e os controles também foram realizados.

Depois de concluídas as biotransformações, os micro-organismos foram separados e os caldos foram submetidos à partição líquido-líquido com acetato de etila. As frações foram secas e submetidas aos procedimentos de isolamento dos metabólitos em CLAE semi-preparativo, de acordo com o item 3.14 (página 37). Os rendimentos dos metabólitos obtidos estão apresentados na Tabela 8 e foram calculados com base na concentração molar de lapachol utilizada em cada cultivo.

Tabela 8. Rendimentos dos metabólitos do lapachol obtidos a partir das biotransformações.

\begin{tabular}{cc}
\hline Metabólito & Rendimento (\%) \\
\hline M1 & 48,79 \\
M2 & 17,16 \\
M3 & 2,61 \\
M4 & 3,73 \\
M5 & 2,66 \\
\hline
\end{tabular}

\subsection{Identificação estrutural dos metabólitos do lapachol}

Os espectros de RMN de todos os metabólitos estão apresentados no apêndice (página 121). Para os metabólitos inéditos na literatura, apresentam-se também os espectros no infravermelho, o de massas em alta resolução (MS) e o de fragmentação (MS/MS).

\subsubsection{Identificação estrutural do metabólito M1}

O metabólito produzido por A. brasiliensis (M1) foi identificado como $4 a$ hidroxi-2,2-dimetil-5-oxo-2,3,4,4a,5,9b-hexahidroindeno[1,2-b]piran-9b ácido carboxílico, um derivado indeno-pirano com rotação óptica de $[\alpha]_{\mathrm{D}}{ }^{20}=-3.73$ (c 0.93 , 
$\mathrm{MeOH})$ e faixa de fusão de $138-140{ }^{\circ} \mathrm{C}$. Tal metabólito não está relatado na literatura e sua estrutura química está apresentada a seguir (Figura 39).

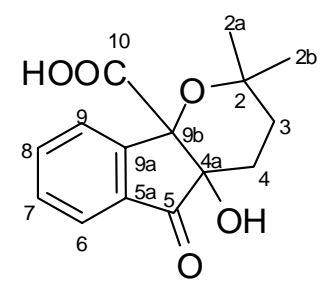

Figura 39. Estrutura química do metabólito M1.

A identificação do metabólito M1 mostrou que as enzimas do fungo A. brasiliensis foram capazes de catalisar a contração no anel quinona do lapachol e transformá-lo no anel de cinco membros formando indenona. Além disso, ocorreu também a heterociclização da cadeia isoprenílica do lapachol para formar o anel tetraidropirano. A identificação de M1 foi possível após análises dos espectros de RMN uni e bidimensionais. Confirmações foram obtidas com as análises dos espectros no infravermelho e de massas de alta resolução.

A correlação entre o hidrogênio na posição 9 e o carbono na posição $9 b$, observada no mapa de contornos de HMBC, além das análises dos espectros de RMN de ${ }^{1} \mathrm{H}$ e ${ }^{13} \mathrm{C}$ evidenciaram a presença do anel pentacíclico e o ácido carboxílico na posição 10 . O grupo cetona $(\delta 204,2)$ na posição 5 do anel pentacíclico foi confirmado pela correlação existente com o hidrogênio na posição 4 , observada no mapa de contornos de HMBC. A presença do anel tetraidropirano também foi confirmada pelas análises dos espectros de $\mathrm{RMN}$ de ${ }^{1} \mathrm{H}$ e de ${ }^{13} \mathrm{C}$, assim como pelo estabelecimento das correlações heteronucleares existentes. $\mathrm{Na}$ Tabela 9 estão apresentados os deslocamentos químicos de ${ }^{1} \mathrm{H}$ e ${ }^{13} \mathrm{C}$ do metabólito M1, bem como as correlações heteronucleares observadas no mapa de contornos de HMBC, as quais estão ilustradas na Figura 40. 


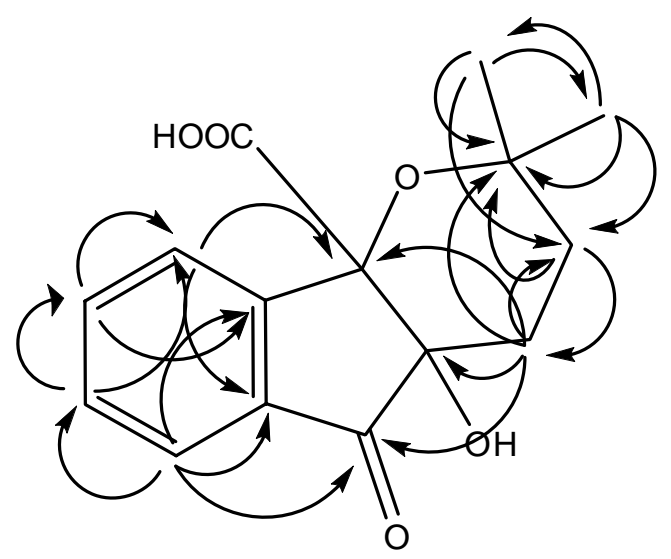

Figura 40. Correlações ${ }^{1} \mathrm{H}^{13}{ }^{13} \mathrm{C}$ do metabólito M1.

Tabela 9. Sinais de $\mathrm{RMN}$ de ${ }^{1} \mathrm{H}(500 \mathrm{MHz}),{ }^{13} \mathrm{C}(125 \mathrm{MHz})$ e $\mathrm{HMBC}$ do metabólito $\mathrm{M} 1$ em $\mathrm{CD}_{3} \mathrm{OD}, \delta$ em ppm.

\begin{tabular}{cccc}
\hline Posição & $\boldsymbol{\delta}_{\mathbf{H}}$ multiplicidade $(\boldsymbol{J}$ em Hz) & $\boldsymbol{\delta}_{\mathbf{C}}$ tipo & HMBC* \\
\hline 2 & - & $85,9 \mathrm{C}$ \\
$2 \mathrm{a}$ & $1,19 \mathrm{~s}$ & $28,6 \mathrm{CH}_{3}$ & $2,2 \mathrm{~b}, 3$ \\
$2 \mathrm{~b}$ & $1,26 \mathrm{~s}$ & $28,5 \mathrm{CH}_{3}$ & $2,2 \mathrm{a}, 3$ \\
3 & $1,71 \mathrm{~m} ; 1,89 \mathrm{~m}$ & $38,3 \mathrm{CH}_{2}$ & $2,2 \mathrm{a}, 4$ \\
4 & $1,71 \mathrm{~m} ; 2,26 \mathrm{~m}$ & $33,7 \mathrm{CH}_{2}$ & $2,3,4 \mathrm{a}, 5,9 \mathrm{~b}$ \\
$4 \mathrm{a}$ & - & $96,8 \mathrm{C}$ & \\
5 & - & $204,2 \mathrm{C}$ & \\
$5 \mathrm{a}$ & & $136,4 \mathrm{C}$ & \\
6 & $7,59 m$ & $136,6 \mathrm{CH}$ & $5,5 \mathrm{a}, 7,9 \mathrm{a}$ \\
7 & $7,59 m$ & $123,8 \mathrm{CH}$ & 8,9 \\
8 & $7,40 m$ & $130,4 \mathrm{CH}$ & $6,7,9,9 \mathrm{a}$ \\
9 & $7,49 m$ & $125,0 \mathrm{CH}$ & $5 \mathrm{a}, 9 \mathrm{~b}$ \\
$9 \mathrm{a}$ & - & $151,1 \mathrm{C}$ & \\
$9 \mathrm{~b}$ & - & $84,0 \mathrm{C}$ & \\
10 & - & $173,8 \mathrm{C}$ & \\
* & \multicolumn{4}{c}{}
\end{tabular}

No espectro de massas de alta resolução do metabólito M1, obtido no modo positivo, foi possível observar a molécula protonada em $\mathrm{m} / \mathrm{z} 277.1057[\mathrm{M}+\mathrm{H}]^{+}$, consistente com a fórmula molecular proposta $\left(\mathrm{C}_{15} \mathrm{H}_{16} \mathrm{O}_{5}, \mathrm{~m} / z\right.$ 276,0998, calculada). Duas bandas em 1725 e $3400 \mathrm{~cm}^{-1}$, características de grupos carbonílicos e hidroxílicos de ácidos carboxílicos, respectivamente, foram evidenciadas no espectro no infravermelho. 


\section{Resultados e Discussões}

Portanto, nota-se que há grandes diferenças estruturais entre a estrutura proposta para M1 e a estrutura do substrato lapachol. Diante da impossibilidade de obtenção de um cristal capaz de difratar os raios-x, o que confirmaria inequivocadamente a estrutura, a literatura foi utilizada para dar maior suporte e explicar como seria possível o aparecimento de um metabólito com tamanha modificação.

Vários trabalhos relatam a conversão do lapachol (1) em nor-lapachol (1b), envolvendo a encurtamento da cadeia prenílica lateral com perda de um carbono, e posterior inversão das posições dos substituintes alquil e hidroxil (Figura 41). Tal reação ocorre mediante a abertura do anel quinona e posterior fechamento de maneira diferente. Esse processo é conhecido como oxidação de Hooker, em homenagem ao seu descobridor Dr. Samuel Hooker, e vem sendo estudado há muitos anos (LEE, TURNBULL e MOORE, 1995).

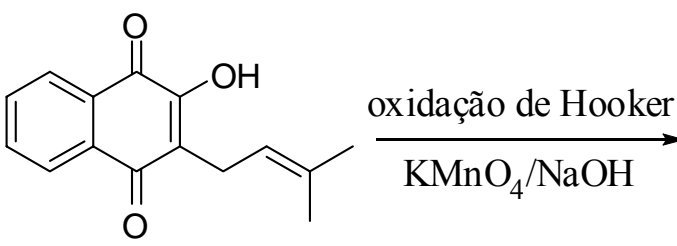

1<smiles>CC(C)=CC1=C(O)C(=O)c2ccccc2C1=O</smiles>

$1 \mathrm{~b}$

Figura 41. Formação de nor-lapachol (1b) a partir de lapachol (1) - oxidação de Hooker.

Embora a oxidação de Hooker pareça ser simples e utilize condições amenas de reação $\left(1 \% \mathrm{KMnO}_{4}-\mathrm{NaOH}, 0{ }^{\circ} \mathrm{C}\right)$, um mecanismo muito interessante está envolvido. Por esse motivo, vários grupos de pesquisa vêm explorando o mecanismo pelo qual tal reação ocorre, na tentativa de encontrar explicações claras para a formação do norlapachol (1b) a partir do lapachol (1) (EYONG et al., 2013b). Fieser e colaboradores propuseram o mecanismo envolvido na oxidação de Hooker (Figura 42), mostrando o envolvimento de um intermediário chave (1a) na reação, chamado então de 
intermediário de Hooker (derivado ácido carboxílico indano) (FIESER e FIESER, 1948; FIESER, HARTWELL e SELIGMAN, 1936).<smiles>CC(C)=CCC1=C(O)C(=O)c2ccccc2C1=O</smiles>

1

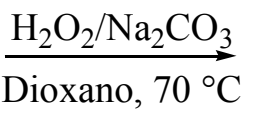

Dioxano, $70{ }^{\circ} \mathrm{C}$<smiles>CC(C)=CCC1(O)C(=O)c2ccccc2C1(O)C(=O)O</smiles>

1a

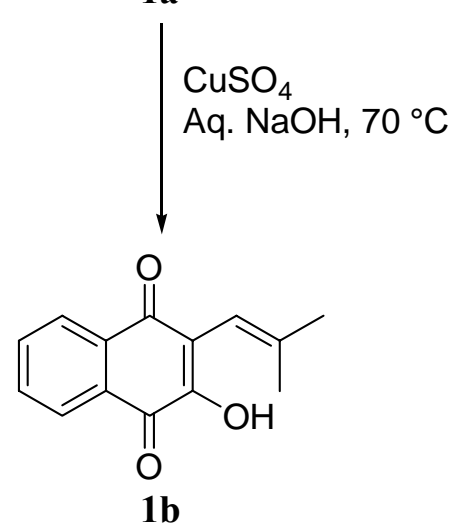

Figura 42. Participação do intermediário de Hooker (1a) na transformação de lapachol (1) em nor-lapachol (1b)

O mecanismo exato de formação do intermediário de Hooker (1a) permaneceu ambíguo por vários anos. Recentemente, Eyong e colaboradores propuseram que a formação de 1a a partir do lapachol ocorreria por meio de rearranjos. Após isso, o intermediário de Hooker (1a) sofreria quebra oxidativa seguida por reação aldólica intramolecular e descarboxilação, gerando o nor-lapachol (1b) (EYONG et al., 2013b). Durante tais estudos, Eyong e colaboradores obtiveram um composto de estrutura muito similar à proposta para M1, sugerindo então que a produção do metabólito M1 a partir do lapachol pelos micro-organismos avaliados pode ter ocorrido de forma similar ao que ocorre na oxidação de Hooker. A Figura 43 mostra o derivado obtido por Eyong e colaboradores a partir do intermediário de Hooker (1a), o qual foi obtido a partir do lapachol. Portanto, tal estudo valida a produção do metabólito M1 a partir do lapachol. 


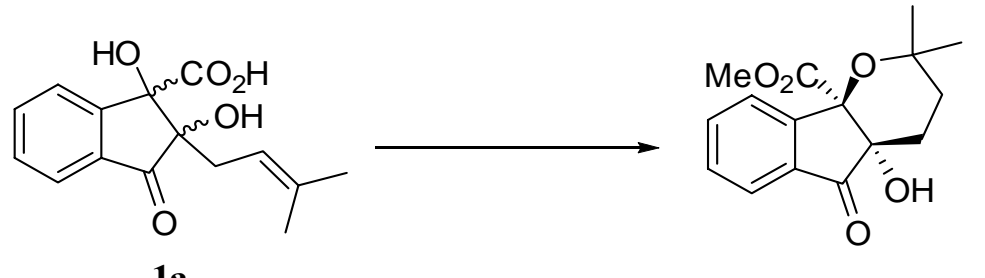

1a

Figura 43. Éter tricíclico obtido a partir do intermediário de Hooker (1a) por Eyong et al. (2013).

\subsubsection{Identificação estrutural do metabólito M2}

O metabólito isolado dos cultivos em grande escala com L. acidophilus foi identificado como 2,2-dimetil-2H-benzo[g]chromeno-5,10-diona (M2). Tal metabólito é conhecido como $\alpha$-xiloidona ou deidro- $\alpha$-lapachona (Figura 44), substância de ocorrência natural com conhecidas e importantes atividades farmacológicas, entre elas, antimicrobiana, anti-inflamatória e antitumoral (RIBEIRO et. al, 2008).

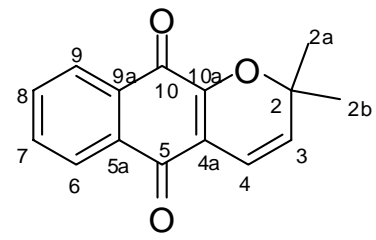

Figura 44. Estrutura química do metabólito M2.

A identificação da substância M2 foi realizada após análise dos dados espectroscópicos (RMN) e comparação desses com os encontrados na literatura. Na Tabela 10 estão os dados de RMN da substância M2 e todos os dados estão de acordo com os deslocamentos químicos da $\alpha$-xiloidona previamente publicados por Lee e Lee em 2004 (dados de RMN de ${ }^{1} \mathrm{H}, 300 \mathrm{MHz}$ ) e Nasiri, Bolte e Schwalbe em 2008 (dados de $\mathrm{RMN}$ de $\left.{ }^{13} \mathrm{C}, 62,9 \mathrm{MHz}\right)$. 
Tabela 10. Sinais de $\mathrm{RMN}$ de ${ }^{1} \mathrm{H}(500 \mathrm{MHz}),{ }^{13} \mathrm{C}(125 \mathrm{MHz})$ e $\mathrm{HMBC}$ do metabólito $\mathbf{M} 2$ em $\mathrm{CDCl}_{3}, \delta$ em ppm, e comparação desses com os da literatura.

\begin{tabular}{|c|c|c|c|c|c|}
\hline \multicolumn{4}{|c|}{ M2 } & \multicolumn{2}{|c|}{ literatura $\left(\mathrm{CDCl}_{3}\right)$} \\
\hline Posição & $\begin{array}{c}\delta_{\mathrm{H}} \text { multiplicidade } \\
(J \mathrm{em} \mathrm{Hz})\end{array}$ & $\delta_{\mathrm{C}}$ tipo & HMBC* & $\begin{array}{c}\delta_{\mathrm{H}} \\
\text { multiplicidade }\end{array}$ & $\delta_{\mathrm{C}}$ \\
\hline 2 & - & $80,5 \mathrm{C}$ & - & - & 80,4 \\
\hline $2 \mathrm{a}$ & $1,55 s$ & $28,3 \mathrm{CH}_{3}$ & $2,2 b, 3,4$ & $1,54 s$ & 28,3 \\
\hline $2 b$ & $1,55 s$ & $28,3 \mathrm{CH}_{3}$ & $2,2 \mathrm{a}, 3,4$ & $1,54 s$ & 28,3 \\
\hline 3 & $5,72 d(9,9)$ & $130,8 \mathrm{CH}$ & $2,2 \mathrm{a}, 4 \mathrm{a}$ & $5,71 d$ & 130,9 \\
\hline 4 & $6,65 d(9,9)$ & $115,6 \mathrm{CH}$ & $2,4 a, 5,10 a$ & $6,64 d$ & 115,4 \\
\hline $4 a$ & - & 117,9 C & - & - & 117,8 \\
\hline 5 & - & $182,0 \mathrm{C}$ & - & - & 181,8 \\
\hline $5 a$ & - & $131,5 \mathrm{C}$ & - & - & 131,4 \\
\hline 6 & $8,09 \mathrm{~m}$ & $126,3 \mathrm{CH}$ & $5,5 \mathrm{a}, 7,8,9 \mathrm{a}, 10$ & $8,11-8,05 \mathrm{~m}$ & 126,2 \\
\hline 7 & $7,69 \mathrm{~m}$ & $133,2 \mathrm{CH}$ & 6,8 & 7,70-7,64 m & 133,2 \\
\hline 8 & $7,69 \mathrm{~m}$ & $134,1 \mathrm{CH}$ & 6,7 & 7,70-7,64 m & 133,9 \\
\hline 9 & $8,09 \mathrm{~m}$ & $126,2 \mathrm{CH}$ & $5,5 \mathrm{a}, 7,8,9 \mathrm{a}, 10$ & $8,11-8,05 m$ & 126,2 \\
\hline $9 a$ & - & $131,6 \mathrm{C}$ & - & - & 131,5 \\
\hline 10 & - & $179,8 \mathrm{C}$ & - & - & 179,8 \\
\hline $10 \mathrm{a}$ & - & $152,4 \mathrm{C}$ & - & - & 152,4 \\
\hline
\end{tabular}

A verificação do deslocamento químico do carbono quaternário (C-2) em $\delta 80,5$ ppm, ligado às duas metilas $2 \mathrm{a}$ e $2 \mathrm{~b}$, mostrou que C-2 está ligado a oxigênio, sugerindo a ciclização da cadeia isoprenílica do lapachol na formação do anel pirano. A observação das constantes de acoplamento entre os hidrogênios nas posições 3 e $4(J=$ 9,9 Hz), permitiu concluir que a configuração relativa observada nessa região é do tipo cis (PAVIA et al., 2010).

Niehues e colaboradores estudaram o metabolismo in vitro do lapachol usando um modelo biomimético com catalisador de Jacobsen. Nesse estudo, 11 derivados foram identificados e usados no desenvolvimento de um método analítico para a identificação de metabólitos provenientes do metabolismo de fase I in vivo. Assim, a análise do plasma de ratos oralmente administrados com dose não-tóxica de lapachol exibiu a presença de dois metabólitos, $\alpha$-lapachona e $\alpha$-xiloidona (NIEHUES et al., 2012). Portanto, o isolamento de $\alpha$-xiloidona a partir da biotransformação do lapachol 
por micro-organismos e sua detecção no plasma de ratos corroboram na inferência de que os modelos microbianos empregados no presente estudo são ferramentas importantes na predição e elucidação do metabolismo de fase I de mamíferos.

\subsubsection{Identificação estrutural do metabólito M3}

O metabólito M3, isolado a partir da biotransformação em escala ampliada do lapachol por C. echinulata var. elegans, foi identificado como 2-hidroxi-3-[(E)-4hidroxi-3-metilbutil-2-enil]naftaleno-1,4-diona (Figura 45). Esse metabólito foi isolado pela primeira vez em 1981, sendo fruto da biotransformação do lapachol por $C$. echinulata NRRL 3655 e foi denominado lomatiol (OTTEN e ROSAZZA, 1981). Após isso, em 1985, o lomatiol foi novamente detectado em experimentos de biotransformação do lapachol por Beauveria sulfurescens ATCC7159 e Streptomyces albus NRRL B. 1865 (DAVID, GAYET e VESCHAMBRE, 1985).

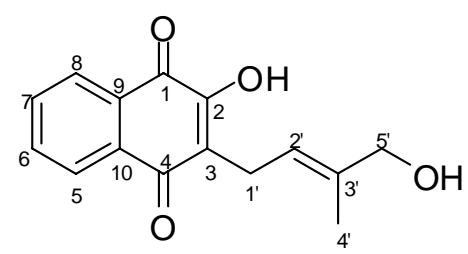

Figura 45. Estrutura química do metabólito M3.

$\mathrm{Na}$ Tabela 11 estão apresentados os deslocamentos químicos dos carbonos e hidrogênios, além das correlações heteronucleares de HMBC e HMQC do metabólito M3. Os sinais de RMN de ${ }^{1} \mathrm{H}$ de $\mathbf{M 3}$ estão de acordo com os obtidos por Otten e Rosazza (1981) para o lomatiol. Uma comparação entre os espectros de RMN de ${ }^{1} \mathrm{H}$ do lapachol e do lomatiol, mostra que o lapachol possui dois simpletos em $\delta$ 1,66 e 1,77 ppm, integrando para três hidrogênios, correspondendo às duas metilas da cadeia alifática. $\mathrm{O}$ espectro de $\mathrm{RMN}$ de ${ }^{1} \mathrm{H}$ do lomatiol possui apenas um simpleto $(\delta 1,84$ 
ppm), integrando para três hidrogênios, mostrando a existência de apenas um grupo metílico. Possui também um novo simpleto em $\delta 4,00 \mathrm{ppm}$, integrando para dois hidrogênios. Da mesma forma como descrito acima, a comparação entre os espectros de $\mathrm{RMN}$ de ${ }^{13} \mathrm{C}$ do lapachol e do lomatiol evidencia a conversão de um grupo metílico do lapachol em hidroxi-metilênico do lomatiol.

Tabela 11. Sinais de RMN de ${ }^{1} \mathrm{H}(500 \mathrm{MHz}),{ }^{13} \mathrm{C}(125 \mathrm{MHz})$ e $\mathrm{HMBC}$ do metabólito $\mathbf{M} 3$ em $\mathrm{CDCl}_{3}, \delta$ em ppm, e comparação desses com os da literatura.

\begin{tabular}{|c|c|c|c|c|}
\hline & M3 & & & $\begin{array}{l}\text { OTTEN e ROSAZZA (1981), } \\
\text { acetona- } \mathrm{d}_{6}\end{array}$ \\
\hline Posição & $\begin{array}{c}\delta_{\mathrm{H}} \text { multiplicidade }(J \\
\text { em Hz) }\end{array}$ & $\delta_{\mathrm{C}}$ tipo & НМBC* & $\delta_{\mathrm{H}}$ multiplicidade \\
\hline 1 & - & $181,8 \mathrm{C}$ & - & - \\
\hline 2 & - & $153,0 \mathrm{C}$ & - & - \\
\hline 3 & - & $122,9 \mathrm{C}$ & - & - \\
\hline 4 & - & $184,6 \mathrm{C}$ & - & - \\
\hline 5 & $8,11 \mathrm{~m}$ & $126,8 \mathrm{CH}$ & $4,6,10$ & $8,01 \mathrm{~m}$ \\
\hline 6 & $7,68 \mathrm{~m}$ & $133,1 \mathrm{CH}$ & 5,10 & $7,80 \mathrm{~m}$ \\
\hline 7 & $7,76 \mathrm{~m}$ & $135,1 \mathrm{CH}$ & 6,8 & $7,80 \mathrm{~m}$ \\
\hline 8 & $8,07 \mathrm{~m}$ & $126,2 \mathrm{CH}$ & $1,6,7$ & $8,01 \mathrm{~m}$ \\
\hline 9 & - & $127,3 \mathrm{C}$ & - & - \\
\hline 10 & - & $129,5 \mathrm{C}$ & - & - \\
\hline 1 & $3,37 d(7,1)$ & $22,1 \mathrm{CH}_{2}$ & $\begin{array}{l}2,2,, 3 \\
3,4\end{array}$ & $3,32 d$ \\
\hline 2 & $5,50 t(7,1)$ & $121,0 \mathrm{CH}$ & $1^{\prime}, 4^{\prime}, 5$ & $5,49 m$ \\
\hline 3 , & - & $137,0 \mathrm{C}$ & - & - \\
\hline 4 & $1,84 s$ & $13,9 \mathrm{CH}_{3}$ & $2^{\prime}, 3^{\prime}, 4^{\prime}$ & $1,80 s$ \\
\hline 5 & $4,00 s$ & $68,8 \mathrm{CH}_{2}$ & 2', 3', 5' & $3,90 s$ \\
\hline
\end{tabular}

A determinação da configuração relativa da ligação dupla entre C-2' e C-3’ foi determinada da mesma forma que a relatada na literatura para essa classe de substâncias, ou seja, nos trabalhos anteriores onde o lomatiol foi isolado, sua configuração $E$ ou $Z$ foi determinada por comparação entre os deslocamentos químicos de seus carbonos com os dos carbonos apresentados por seus análogos $E$ e $Z$ 2-metil-2buten-1-ol (DAVID, GAYET e VESCHAMBRE, 1985). Os deslocamentos químicos 
dos carbonos relevantes para a determinação da configuração relativa estão apresentados na Figura 46.
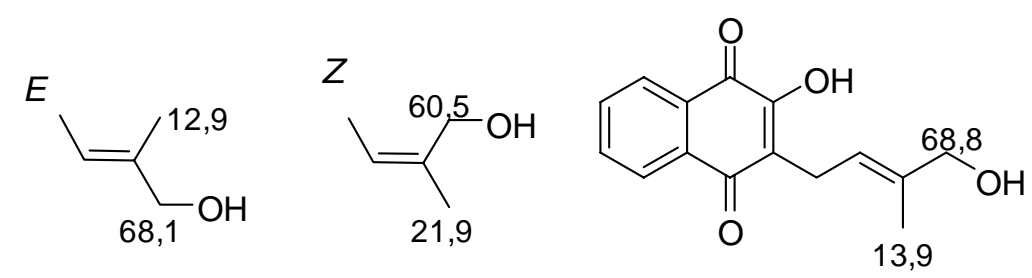

Figura 46. Deslocamentos químicos (ppm) dos ${ }^{13} \mathrm{C}$ dos isômeros $E$ e $Z$ do 2metil-2-buten-1-ol e do lomatiol implicados na determinação da configuração relativa.

Portanto, a comparação entre os deslocamentos químicos dos carbonos das substâncias apresentadas na Figura 46, possibilita sugerir que o lomatiol isolado no presente estudo possui configuração $E$. Tal fato é justificado pelo valor do sinal da metila ( $\delta 13,9 \mathrm{ppm})$, a qual apresenta-se com valor semelhante ao da mesma metila do isômero $E$ da substância utilizada na comparação.

O lomatiol é também naturalmente encontrado em sementes de espécies de Lomatia, árvore australiana. A biossíntese do lomatiol provavelmente inicia-se com o ácido chiquímico, via ácido o-succinoilbenzóico, com posterior prenilação (MOIR e THOMSON, 1973).

Estudos acerca do metabolismo do lapachol em mamíferos, utilizando cachorros, mostraram o lomatiol como metabólito (RAO, 1974). Dessa forma, conclui-se que a utilização do gênero Cunninghamella é válida nos estudos sobre o metabolismo in vitro do lapachol.

\subsubsection{Identificação estrutural do metabólito M4}

O metabólito M4, isolado dos cultivos em escala ampliada com $B$. cinerea UCA 992, foi caracterizado como 3'-hidroxilapachol ou 2-hidroxi-3-(3'-hidroxi-3metilbutil)naftaleno-1,4-diona, sua estrutura química está apresentada na Figura 47. 


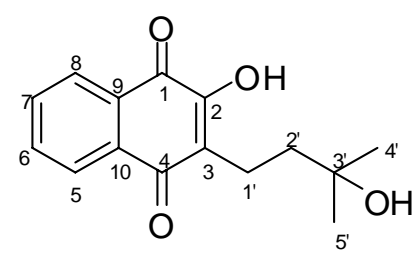

Figura 47. Estrutura química do metabólito M4.

Os dados de RMN de ${ }^{1} \mathrm{H}$ e de ${ }^{13} \mathrm{C}$, bem como suas correlações ${ }^{1} \mathrm{H}-{ }^{13} \mathrm{C}$ estão apresentados na Tabela 12. A identificação dessa estrutura foi realizada após análise dos deslocamentos químicos de ${ }^{1} \mathrm{H}$ e ${ }^{13} \mathrm{C}$, além da comparação com os deslocamentos químicos dos ${ }^{1} \mathrm{H}$ e ${ }^{13} \mathrm{C}$ apresentados pelo lapachol. Os carbonos 2' e 3' do lapachol são observados em $\delta 121,6$ ppm e 134,0 ppm, respectivamente, evidenciando a insaturação existente nessa região. No espectro de ${ }^{13} \mathrm{C}$ do metabólito M4 tais carbonos apresentam $\delta$ 42,3 ppm e 71,3 ppm, respectivamente. Além disso, o mapa de contornos de HMQC do M4 mostrou que o carbono $\delta$ 42,3 ppm (C-2') forma um grupo metilênico com hidrogênios em $\delta$ 1,60 ppm, enquanto o carbono $\delta$ 71,3 ppm (C-3') é quaternário, tipicamente ligado a hidroxila alcoólica. Todos os dados de RMN do metabólito M4 estão de acordo com os deslocamentos químicos de ${ }^{1} \mathrm{H}$ e de ${ }^{13} \mathrm{C}$ do 3 '-hidroxilapachol reportados por Cunha-Filho et al. (2011). 
Tabela 12. Sinais de $\mathrm{RMN}$ de ${ }^{1} \mathrm{H}(500 \mathrm{MHz}),{ }^{13} \mathrm{C}(125 \mathrm{MHz})$ e $\mathrm{HMBC}$ do metabólito M4 em $\mathrm{CD}_{3} \mathrm{OD}, \delta$ em ppm, e comparação desses com os da literatura (300 e $100 \mathrm{MHz})$.

\begin{tabular}{|c|c|c|c|c|c|}
\hline \multirow[b]{2}{*}{ Posição } & \multicolumn{2}{|l|}{ M4 } & \multicolumn{3}{|c|}{$\begin{array}{c}\text { CUNHA-FILHO et al., } \\
2011\left(\mathrm{CDCl}_{3}\right)\end{array}$} \\
\hline & $\begin{array}{c}\delta_{\mathrm{H}} \text { multiplicidade } \\
(J \text { em Hz })\end{array}$ & $\delta_{\mathrm{C}}$ tipo & HMBC* & $\begin{array}{c}\delta_{\mathrm{H}} \\
\text { multiplicidade } \\
\end{array}$ & $\delta_{\mathrm{C}}$ \\
\hline 1 & - & $183,0 \mathrm{C}$ & - & - & $\overline{181,4}$ \\
\hline 2 & - & $158,5 \mathrm{C}$ & - & - & 153,1 \\
\hline 3 & - & $125,1 \mathrm{C}$ & - & - & 124,7 \\
\hline 4 & - & $186,1 \mathrm{C}$ & - & - & 184,7 \\
\hline 5 & $7,99 d d(1,73 ; 7,5)$ & $126,5 \mathrm{CH}$ & 4,6 & $8,05 \mathrm{~m}$ & 126,6 \\
\hline 6 & $7,71 \mathrm{~m}$ & $135,0 \mathrm{CH}$ & 5,10 & $7,69 \mathrm{~m}$ & 134,8 \\
\hline 7 & $7,66 m$ & $133,2 \mathrm{CH}$ & 8,9 & $7,63 \mathrm{~m}$ & 132,8 \\
\hline 8 & $7,99 d d(1,73 ; 7,5)$ & $126,5 \mathrm{CH}$ & 4,6 & $8,05 \mathrm{~m}$ & 126,1 \\
\hline 9 & - & $131,5 \mathrm{C}$ & - & - & 129,5 \\
\hline 10 & - & $134,2 \mathrm{C}$ & - & - & 132,8 \\
\hline 1 ' & $2,60 \mathrm{~m}$ & $19,0 \mathrm{CH}_{2}$ & $2^{\prime}, 3,3^{\prime}, 4$ & $2,67 \mathrm{~m}$ & 18,3 \\
\hline 2 ' & $1,60 \mathrm{~m}$ & $42,3 \mathrm{CH}_{2}$ & $1^{\prime}, 3,3^{\prime}, 4^{\prime}, 5^{\prime}$ & $1,68 \mathrm{~m}$ & 41,5 \\
\hline 3 , & - & $71,3 \mathrm{C}$ & - & - & 71,0 \\
\hline 4 & $1,22 s$ & $28,6 \mathrm{CH}_{3}$ & $2^{\prime}, 3^{\prime}, 5^{\prime}$ & 1,29 & 29,1 \\
\hline 5 & $1,22 s$ & $28,6 \mathrm{CH}_{3}$ & $2^{\prime}, 3^{\prime}, 4^{\prime}$ & 1,29 & 29,1 \\
\hline
\end{tabular}

correlações de $\mathrm{HMBC}$, otimizadas para $6 \mathrm{~Hz}$, são do ${ }^{1} \mathrm{H}$ para o ${ }^{13} \mathrm{C}$ indicado

Vários estudos relatam a produção e avaliação das bioatividades do 3'-hidroxilapachol. Um estudo nesse sentido foi publicado por Subramanian, Ferreira e Trsic, em 1998. Em tal trabalho, os autores mostraram a relação estrutura-atividade do lapachol, lomatiol e 3'-hidroxilapachol contra carcinosarcoma Walker 256. Ficou evidente que a presença da ligação dupla na cadeia alquílica lateral é importante para a atividade biológica, pois os elétrons $\pi$ agem como agentes redutores e participam das reações de oxirredução, gerando radicais livres e estresse oxidativo nas células tratadas. Assim, no ensaio citotóxico, o lapachol apresentou $79 \%$ de atividade e o lomatiol $58 \%$, enquanto o 3'-hidroxilapachol mostrou apenas $10 \%$ de atividade contra Walker 256.

A atividade tripanocida do 3'-hidroxilapachol e de alguns de seus análogos estruturais foi avaliada in vitro contra Trypanossoma cruzi. De todas as naftoquinonas testadas, o 3'-hidroxilapachol foi o menos ativo (SALAS et al., 2008). 
4.9.5 Identificação estrutural do metabólito M5

O metabólito M5, 3-hidroxi-2-(2-hidroxipropan-2-il)-2,3-diidronaftol[2,3b]furan-4,9-diona, produzido a partir da biotransformação do lapachol em grande escala por M. circinelloides $(+)$ foi identificado utilizando-se os espectros de RMN de ${ }^{1} \mathrm{H}$ e ${ }^{13} \mathrm{C}$, bem como HMQC e HMBC. A estrutura química está apresentada na Figura 48.

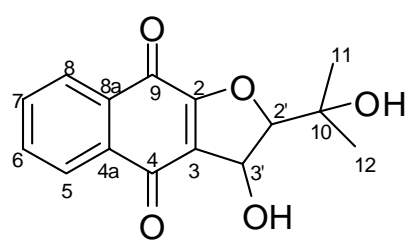

Figura 48. Estrutura química do metabólito M5.

O metabólito M5 foi identificado pela primeira vez no ano 2000 por Ito e colaboradores. Ele foi denominado de avicequinona-A por ter sido isolado da casca do caule de Avicennia alba (Avicenniaceae), coletada em Cingapura. Essa árvore é típica de mangues e cresce na foz dos rios.

Na Tabela 13 estão apresentados os deslocamentos químicos de ${ }^{1} \mathrm{H}$ e ${ }^{13} \mathrm{C}$, e as correlações heteronucleares da avicequinona-A. Todos os dados estão de acordo com o descrito por Ito e colaboradores (2000). 
Tabela 13. Sinais de $\mathrm{RMN}$ de ${ }^{1} \mathrm{H}(500 \mathrm{MHz}),{ }^{13} \mathrm{C}(125 \mathrm{MHz})$ e $\mathrm{HMBC}$ do metabólito M5 em $\mathrm{CDCl}_{3}, \delta$ em ppm, e comparação desses com os da literatura (400 e $100 \mathrm{MHz}$ ).

\begin{tabular}{cccc|cc}
\hline & M5 & & \multicolumn{3}{c}{ ITO et al., 2000 $\left(\mathrm{CDCl}_{3}\right)$} \\
\hline Posição & $\begin{array}{c}\boldsymbol{\delta}_{\mathbf{H}} \text { multiplicidade } \\
(\boldsymbol{J} \text { em Hz })\end{array}$ & $\boldsymbol{\delta}_{\mathbf{C}}$ tipo & HMBC* & $\begin{array}{c}\boldsymbol{\delta}_{\mathbf{H}} \\
\text { multiplicidade }\end{array}$ & $\boldsymbol{\delta}_{\mathbf{C}}$ \\
\hline 2 & - & $160,7 \mathrm{C}$ & - & - & 160,6 \\
3 & - & $124,9 \mathrm{C}$ & - & - & 124,8 \\
4 & - & $182,7 \mathrm{C}$ & - & - & 182,6 \\
5 & $8,09 m$ & $126,8 \mathrm{CH}$ & $4,6,4 \mathrm{a}$ & $8,08 d d$ & 126,1 \\
6 & $7,74 m$ & $134,7 \mathrm{CH}$ & 7,8 & $7,76 d t$ & 134,5 \\
7 & $7,74 m$ & $133,5 \mathrm{CH}$ & 4,8 & $7,71 d t$ & 133,3 \\
8 & $8,09 m$ & $126,2 \mathrm{CH}$ & 7,9 & $8,10 d d$ & 126,6 \\
9 & - & $178,2 \mathrm{C}$ & - & - & 178,1 \\
10 & - & $71,2 \mathrm{C}$ & - & - & 71,0 \\
11 & $1,35 s$ & $24,6 \mathrm{CH} 3$ & $2,10,12$ & $1,35 s$ & 24,4 \\
12 & $1,43 s$ & $26,0 \mathrm{CH} 3$ & $2,10,11$ & $1,44 s$ & 25,8 \\
$4 \mathrm{a}$ & - & $132,9 \mathrm{C}$ & - & - & 132,6 \\
$8 \mathrm{a}$ & - & $131,9 \mathrm{C}$ & - & - & 131,7 \\
2 & $4,54 d(5,1)$ & $98,5 \mathrm{CH}$ & 2,3 & $4,54 d$ & 98,4 \\
3 & $5,62 d(5,1)$ & $72,1 \mathrm{CH}$ & $2,3,10$ & $5,62 d$ & 71,9 \\
\hline
\end{tabular}

correlações de $\mathrm{HMBC}$, otimizadas para $6 \mathrm{~Hz}$, são do ${ }^{1} \mathrm{H}$ para o ${ }^{13} \mathrm{C}$ indicado

As comparações entre os espectros de $\mathrm{RMN}$ de ${ }^{1} \mathrm{H}$ e de ${ }^{13} \mathrm{C}$ do metabólito M5 com os espectros do lapachol mostraram que as transformações estruturais ocorreram na cadeia alquílica lateral do lapachol. A presença da correlação $\mathcal{J}^{\mathcal{3}}$ entre H-2' e C-2 evidenciou a ciclização da cadeia alquílica para formação do anel diidrofurano. Os dois grupos metílicos (posições 11 e 12) continuaram como simpletos, portanto ligados a carbono quaternário, externo ao anel e ligado a hidroxila alcoólica ( $\delta 71,2 \mathrm{ppm})$. $\mathrm{O}$ deslocamento químico observado e atribuído ao C-3' $(\delta 72,1 \mathrm{ppm})$ sugere a presença de outra hidroxila alcoólica nessa região da estrutura. A coincidência no valor das constantes de acoplamento entre H-2' e H-3' $(J=5,1 \mathrm{~Hz})$ evidenciou que ambos eram vizinhos. 
Segundo Ito e colaboradores, a orientação trans dos hidrogênios nas posições 2' e $3^{\prime}$ pode ser proposta baseando-se nas constantes de acoplamento $(J=5,1 \mathrm{~Hz})$ apresentadas por esses dois grupos (ITO et al., 2000).

Após o isolamento da avicequinona-A da Avicennia alba (ITO et al., 2000), a mesma naftoquinona foi isolada de Avicennia marina, coletada dos mangues chineses (HAN et al., 2007). As atividades citotóxicas e antimicrobianas da avicequinona-A foram avaliadas e comparadas com aquelas apresentadas por alguns de seus análogos estruturais. Quando a atividade anticâncer foi estudada, a avicequinona-A e seus análogos que continham um grupo hidroxílico alcoólico no anel diidrofurano mostraram ser os agentes mais potentes (ITOIGAWA et al., 2001). Em relação à atividade antimicrobiana frente a várias bactérias e um fungo, a avicequinona-A mostrou fraca atividade. A comparação com os resultados obtidos nos testes empregando seus análogos mostrou a importância da presença do sistema quinona $\alpha, \beta$-insaturada para o aparecimento da atividade antimicrobiana (HAN et al., 2007).

\subsection{Estudos acerca da produção do metabólito M1 a partir da}

\section{biotransformação do lapachol por $A$. brasiliensis}

Como descrito no item 4.9.1 (página 66), o metabólito M1 foi identificado como possuidor de uma estrutura muito interessante e nunca relatada na literatura. Tal metabólito foi obtido em alto rendimento (48,79 \%), ou seja, a obtenção de M1 a partir da biotransformação do lapachol por A. brasiliense, em apenas 24 horas de cultivo, implicou na eliminação completa do lapachol do meio de cultura e aparecimento de somente um metabólito majoritário.

Além disso, como também descrito no item 4.9.1, a identificação estrutural de M1 foi sustentada pela oxidação de Hooker (Figura 49), uma reação muito importante 
em química orgânica e que produz derivados do lapachol semelhantes ao M1 (EYONG et al., 2013b). Diante disso, iniciou-se a investigação sobre a capacidade do fungo $A$. brasiliensis transformar o lapachol da mesma forma que a oxidação de Hooker, ou seja, hipotetizou-se que o lapachol poderia estar sendo biotransformado em M1 por $A$. brasiliensis da mesma forma que a proposta no trabalho de Eyong e colaboradores.<smiles>CC(C)=CCC1=C(O)C(=O)c2ccccc2C1=O</smiles>

1<smiles>CC(C)=CCC1(O)C(=O)c2ccccc2C1(O)C(=O)O</smiles>

$1 \mathbf{a}$<smiles>CC(C)=CC1=C(O)C(=O)c2ccccc2C1=O</smiles>

Figura 49. Formação do intermediário de Hooker (1a) e nor-lapachol (1b) durante a oxidação de Hooker do lapachol (1).

A fim de comprovar a capacidade de $A$. brasiliensis em mimetizar a oxidação de Hooker, seria necessário o isolamento do intermediário de Hooker (1a), ou estrutura semelhante, do mesmo meio de cultura onde o lapachol (1) foi transformado em M1. Porém, utilizando-se o meio de cultura Koch's K1 isso não foi possível, pois, como dito anteriormente, somente o metabólito M1 foi formado. A partir de então se iniciaram testes alterando-se a fonte de nitrogênio do meio Koch's K1 de peptona para fenilalanina, prolina ou triptofano. Tais alterações visaram à detecção e isolamento de M1 e de um intermediário que comprovasse que os mecanismos de reação implicados 
na oxidação de Hooker estavam sendo catalisados pelas enzimas do A. brasiliensis na biotransformação do lapachol.

Felizmente, quando a fonte de nitrogênio do meio Koch's K1 foi alterada de peptona para o aminoácido fenilalanina (Koch's K1 modificado), e todos os outros parâmetros de cultivo foram mantidos, foi possível o isolamento de dois metabólitos: M1 desidratado, chamado agora de M6, e M7, um derivado do intermediário de Hooker. O cromatograma (Figura 50) a seguir mostra o resultado desse novo experimento.

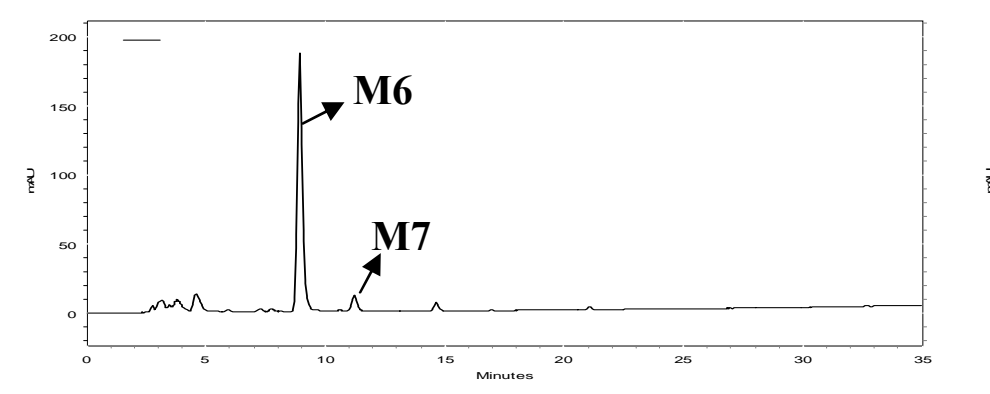

Figura 50. Perfil cromatográfico da fração em acetato de etila dos metabólitos produzidos por A. brasiliensis, em meio Koch's K1 modificado.

Os metabólitos M6 e M7 foram isolados por CLAE na modalidade semipreparativa, de acordo com as condições cromatográficas descritas no item 3.14 (página 37), e suas estruturas foram identificadas conforme descrito a seguir.

\subsubsection{Identificação estrutural do metabólito M6}

O metabólito M6 foi identificado como 2,2-dimetil-5-oxo-2,3,5,9btetraidroindeno[1,2-b]piran-9b-ácido carboxílico e sua estrutura química está apresentada na Figura 51. 


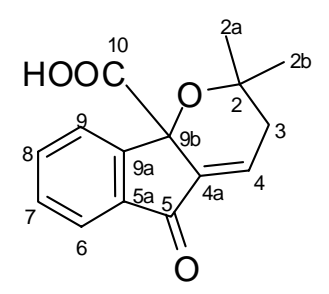

Figura 51. Estrutura química do metabólito M6.

A elucidação estrutural do metabólito M6 foi realizada por comparação entre seus espectros de RMN de ${ }^{1} \mathrm{H}$ e de ${ }^{13} \mathrm{C}$ com os do metabólito M1, além da interpretação dos espectros de RMN bidimensionais. Notáveis foram as alterações nos deslocamentos químicos dos carbonos 4 e 4a. Em M1 eles encontram-se em $\delta$ 33,7 ppm e 96,8 ppm, respectivamente, e C-4 é um grupo metilênico. Já em M6, os mesmos carbonos encontram-se em $\delta 119,2$ ppm e 135,4 ppm, respectivamente, sugerindo a existência de uma insaturação entre tais carbonos. $\mathrm{O}$ fato de C-4 ser um grupo metínico (observado no mapa de contornos de HMQC) e o espectro de massas de alta resolução conter o pico base em $m / z$ 299,0906 $\left[\mathrm{M}+\mathrm{H}_{2} \mathrm{O}+\mathrm{Na}\right]^{+}$sugerem que o metabólito M6 possui a mesma fórmula molecular que M1 $\left(\mathrm{m} / \mathrm{z} 277,1057[\mathrm{M}+\mathrm{H}]^{+}\right)$, porém sem uma molécula de água. O espectro no infravermelho de M6 observam-se bandas em 1725 e $3400 \mathrm{~cm}^{-1}$ (como em M1), evidenciando a permanência do grupo ácido carboxílico.

Na Tabela 14 estão apresentados os sinais de ${ }^{1} \mathrm{H}$ e ${ }^{13} \mathrm{C}$, bem como as correlações observadas no mapa de contornos de HMBC de M6. 
Tabela 14. Sinais de RMN de ${ }^{1} \mathrm{H}(500 \mathrm{MHz}),{ }^{13} \mathrm{C}(125 \mathrm{MHz})$ e $\mathrm{HMBC}$ do metabólito $\mathrm{M6}$ em $\mathrm{CD}_{3} \mathrm{OD}, \delta$ em ppm.

\begin{tabular}{cccc}
\hline Posição & $\begin{array}{c}\boldsymbol{\delta}_{\mathbf{H}} \text { multiplicidade } \\
(\boldsymbol{J} \text { em Hz })\end{array}$ & $\boldsymbol{\delta}_{\mathbf{C}}$ tipo & HMBC* \\
\hline 2 & - & $88,9 \mathrm{C}$ & \\
$2 \mathrm{a}$ & $1,35 \mathrm{~s}$ & $17,7 \mathrm{CH}_{3}$ & $2,2 \mathrm{~b}, 4,4 \mathrm{a}$ \\
$2 \mathrm{~b}$ & $1,49 \mathrm{~s}$ & $25,9 \mathrm{CH}_{3}$ & $2,2 \mathrm{a}, 4,4 \mathrm{a}$ \\
3 & $2,15 d d(7,6 ; 14,8) ; 2,60 d d(7,4 ; 14,8)$ & $35,7 \mathrm{CH}_{2}$ & $2,4,4 \mathrm{a}, 5,9 \mathrm{~b}$ \\
4 & $5,02 t(7,4)$ & $119,2 \mathrm{CH}$ & $2 \mathrm{a}, 2 \mathrm{~b}, 3,9 \mathrm{~b}$ \\
$4 \mathrm{a}$ & - & $135,4 \mathrm{C}$ & \\
5 & - & $204,1 \mathrm{C}$ & \\
$5 \mathrm{a}$ & & $136,2 \mathrm{C}$ & \\
6 & $7,61 \mathrm{~m}$ & $136,8 \mathrm{CH}$ & $5 \mathrm{a}, 7,9 \mathrm{~b}$ \\
7 & $7,50 \mathrm{~m}$ & $123,8 \mathrm{CH}$ & $6,8,9 \mathrm{a}$ \\
8 & $7,68 \mathrm{~m}$ & $130,6 \mathrm{CH}$ & 6,7 \\
9 & $7,68 \mathrm{~m}$ & $124,8 \mathrm{CH}$ & $5,8,9 \mathrm{a}$ \\
$9 \mathrm{a}$ & - & $151,4 \mathrm{C}$ & \\
$9 \mathrm{~b}$ & - & $84,9 \mathrm{C}$ & \\
10 & - & $174,5 \mathrm{C}$ & \\
* correlações de HMBC, otimizadas para $6 \mathrm{~Hz}$, são do ${ }^{11} \mathrm{H}$ para o ${ }^{13} \mathrm{C}$ indicado
\end{tabular}

\subsubsection{Identificação estrutural do metabólito M7}

Como dito anteriormente, para a comprovação da hipótese de que o fungo $A$. brasiliense foi capaz de mimetizar as reações às quais o lapachol é submetido durante a oxidação de Hooker, seria necessário o isolamento de um intermediário semelhante ao intermediário de Hooker (1a).

O metabólito M7 (Figura 52) foi isolado com rendimento de 3,30 \% e identificado como 2-hidroxi-2-(3-metilbutil-2-enil)-1H-indeno-1,3(2H)-diona, um derivado do intermediário de Hooker (1a).

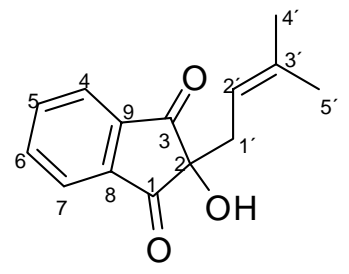

Figura 52. Estrutura química do metabólito M7. 
A estrutura de $\mathbf{M} 7$ foi identificada com base em seus sinais de $\mathrm{RMN}$ de ${ }^{1} \mathrm{H}$ e de ${ }^{13} \mathrm{C}$, além das análises das correlações heteronucleares existentes. Na Tabela 15 estão apresentados todos os dados de RMN de M7, além dos sinais de $\mathrm{RMN}$ de ${ }^{1} \mathrm{H}$ e de ${ }^{13} \mathrm{C}$ relatados por Eyong et. al (2012). Todos os dados espectrais de M7 estão de acordo com o apresentado por Eyong et. al (2012).

Tabela 15. Sinais de $\mathrm{RMN}$ de ${ }^{1} \mathrm{H}(500 \mathrm{MHz}),{ }^{13} \mathrm{C}(125 \mathrm{MHz})$ e $\mathrm{HMBC}$ do metabólito $\mathbf{M} 7$ em $\mathrm{CD}_{3} \mathrm{OD}, \delta$ em ppm, e comparação desses com os da literatura $(400 \mathrm{e}$ $100 \mathrm{MHz}$ ).

\begin{tabular}{|c|c|c|c|c|c|}
\hline \multicolumn{4}{|c|}{ M7 } & \multicolumn{2}{|c|}{ EYONG et. al (2012), $\mathrm{CDCl}_{3}$} \\
\hline Posição & $\begin{array}{c}\delta_{\mathrm{H}} \text { multiplicidade } \\
(J \text { em Hz })\end{array}$ & $\delta_{\mathrm{C}}$ tipo & НМВС* & $\begin{array}{c}\delta_{\mathrm{H}} \\
\text { multiplicidade }\end{array}$ & $\boldsymbol{\delta}_{\mathrm{C}}$ \\
\hline 1 & - & $202,8 \mathrm{C}$ & & - & 199,5 \\
\hline 2 & - & $138,0 \mathrm{C}$ & & - & 149,0 \\
\hline 3 & - & $202,8 \mathrm{C}$ & & - & 199,5 \\
\hline 4 & $7,96 s l$ & $137,5 \mathrm{CH}$ & $3,5,9$ & $7,9 m$ & 136,2 \\
\hline 5 & $7,96 s l$ & $123,9 \mathrm{CH}$ & 4,6 & $7,8 m$ & 123,7 \\
\hline 6 & $7,96 s l$ & $123,9 \mathrm{CH}$ & 5,7 & $7,8 m$ & 123,7 \\
\hline 7 & $7,96 s l$ & $137,5 \mathrm{CH}$ & $1,6,8$ & $7,9 m$ & 136,2 \\
\hline 8 & - & $142,0 \mathrm{C}$ & & - & 140,3 \\
\hline 9 & - & $142,0 \mathrm{C}$ & & - & 140,3 \\
\hline 1 ' & $2,61 d(7,7)$ & $35,4 \mathrm{CH}_{2}$ & $2,2^{\prime}, 3,3^{\prime}$ & $2,5 d$ & 35,2 \\
\hline $2^{\prime}$ & $4,74 t(7,7)$ & $116,7 \mathrm{CH}$ & & $4,9 m$ & 114,7 \\
\hline $3^{\prime}$ & - & $78,6 \mathrm{C}$ & & - & 77,5 \\
\hline $4^{\prime}$ & $1,50 \mathrm{~s}$ & $17,5 \mathrm{CH}_{3}$ & $2,2^{\prime}, 5$ & $1,5 \mathrm{~s}$ & 17,7 \\
\hline 5 , & $1,42 s$ & $25,4 \mathrm{CH}_{3}$ & $2,2^{\prime}, 4^{\prime}$ & $1,5 \mathrm{~s}$ & 25,8 \\
\hline
\end{tabular}

Assim, conclui-se que M7 possui estrutura semelhante à do intermediário de Hooker (1a). A obtenção de M7 a partir do lapachol (1), tendo como intermediário 1a, já foi comprovada por Eyong e colaboradores (2012), como apresentado na Figura 53. 
<smiles>CC(C)=CCC1=C(O)C(=O)c2ccccc2C1=O</smiles>

1<smiles>CC(C)=CCC1(O)C(=O)c2ccccc2C1=O</smiles>

M7<smiles>CC(C)=CC[C@@]1(O)C(=O)c2ccccc2[C@@]1(O)C(=O)O</smiles>

$1 \mathbf{a}$<smiles>[In]I</smiles>

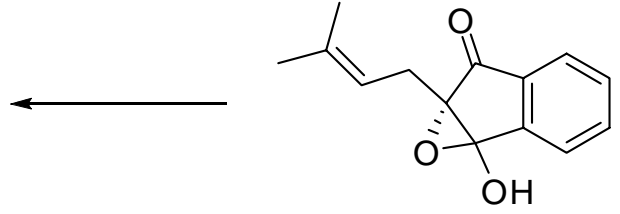

Figura 53. Produção de M7 a partir do lapachol (1), passando pelo intermediário de Hooker (1a).

As bioatividades antimicobacteriana e antibacteriana de $\mathbf{M 7}$ foram avaliadas e indicam que tal substância pode ser considerada como ponto de partida para o desenvolvimento de fármacos com essas finalidades (EYONG et al., 2012).

\subsubsection{Estudos sobre a cinética de formação de M6}

Finalmente, outra investigação tornou-se necessária a fim de comprovar a capacidade de $A$. brasiliensis em mimetizar a oxidação de Hooker: comprovar que o lapachol estava sendo primeiramente transformado em $\mathbf{M 7}$ e, então, transformado em M6.

Para isso, a biotransformação do lapachol por A. brasiliensis foi monitorada a cada hora, durante as seis primeiras horas de cultivo e depois em intervalos de seis horas até que se completassem 24 horas. Na Figura 54 estão apresentados os cromatogramas obtidos das frações em acetato de etila de cada uma das alíquotas tomadas.

As análises dos cromatogramas da Figura 54 mostram que em duas horas de cultivo há somente lapachol, ou seja, a biotransformação demora duas horas para 
iniciar-se. A produção de M6 e M7 teve início após quatro horas de cultivo e, após seis horas de incubação, o substrato não foi mais detectado. Tais cromatogramas também mostram que a produção de M6 e M7 depende de um intermediário comum, pois notase que com o passar do tempo, a quantidade de $\mathbf{M 7}$ diminui enquanto a de M6 aumenta.
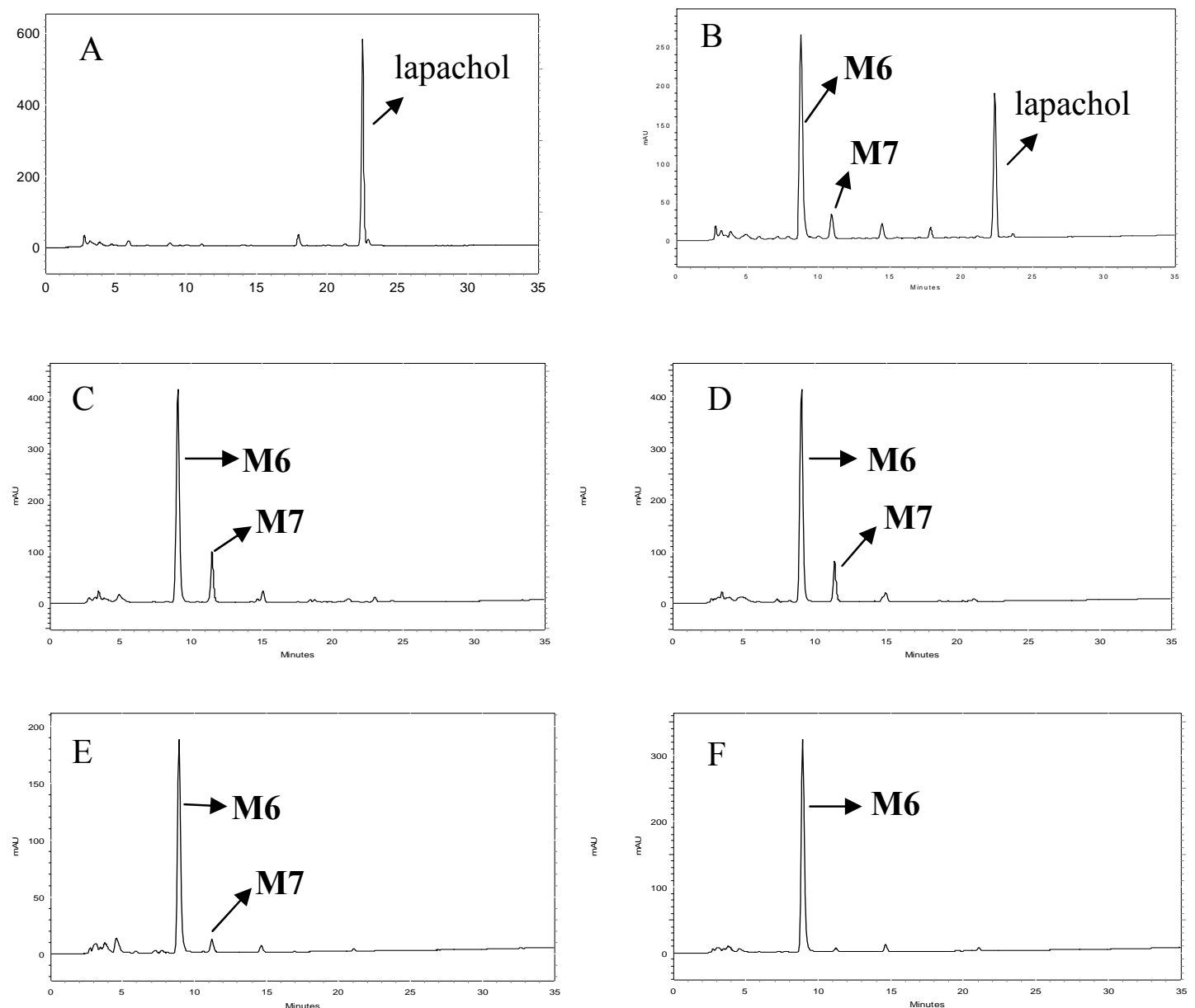

Figura 54. Cromatogramas das frações em acetato de etila de diferentes alíquotas da biotransformação do lapachol (1) por A. brasiliensis em M6 e M7. A: 2 horas de cultivo; B: 4 horas de cultivo; C: 6 horas de cultivo; D: 12 horas de cultivo; E: 18 horas de cultivo; F: 24 horas de cultivo.

Na Figura 55 está apresentada a curva concentração x tempo da produção de M6 e desaparecimento de M7. 


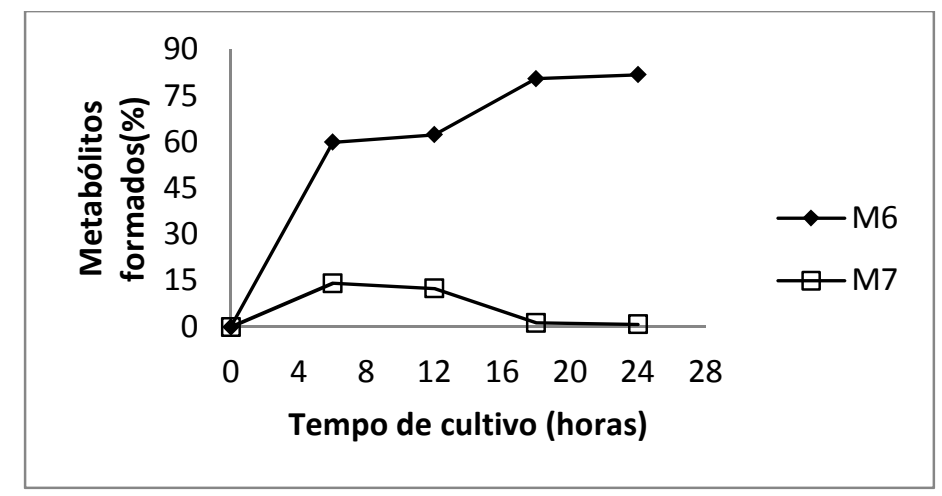

Figura 55. Produção de M6 e desaparecimento de $\mathbf{M 7}$ do meio de cultura onde o lapachol foi biotransformado por A. brasiliensis.

Portanto, confirma-se que a produção de M6 depende do desaparecimento de M7, ou seja, a produção de ambos os metabólitos a partir do lapachol utiliza via e intermediários comuns. Essa informação corrobora na inferência de que o lapachol é primeiramente transformado por A. brasiliensis no intermediário de Hooker (1a) que é então convertido em M6 ou M7. Na Figura 56 está apresentado o mecanismo de formação de M6 e M7 a partir do lapachol, utilizando o intermediário de Hooker (1a). Assim, confirma-se que o fungo filamentoso $A$. brasiliensis possui enzimas capazes de mimetizar a oxidação de Hooker. 


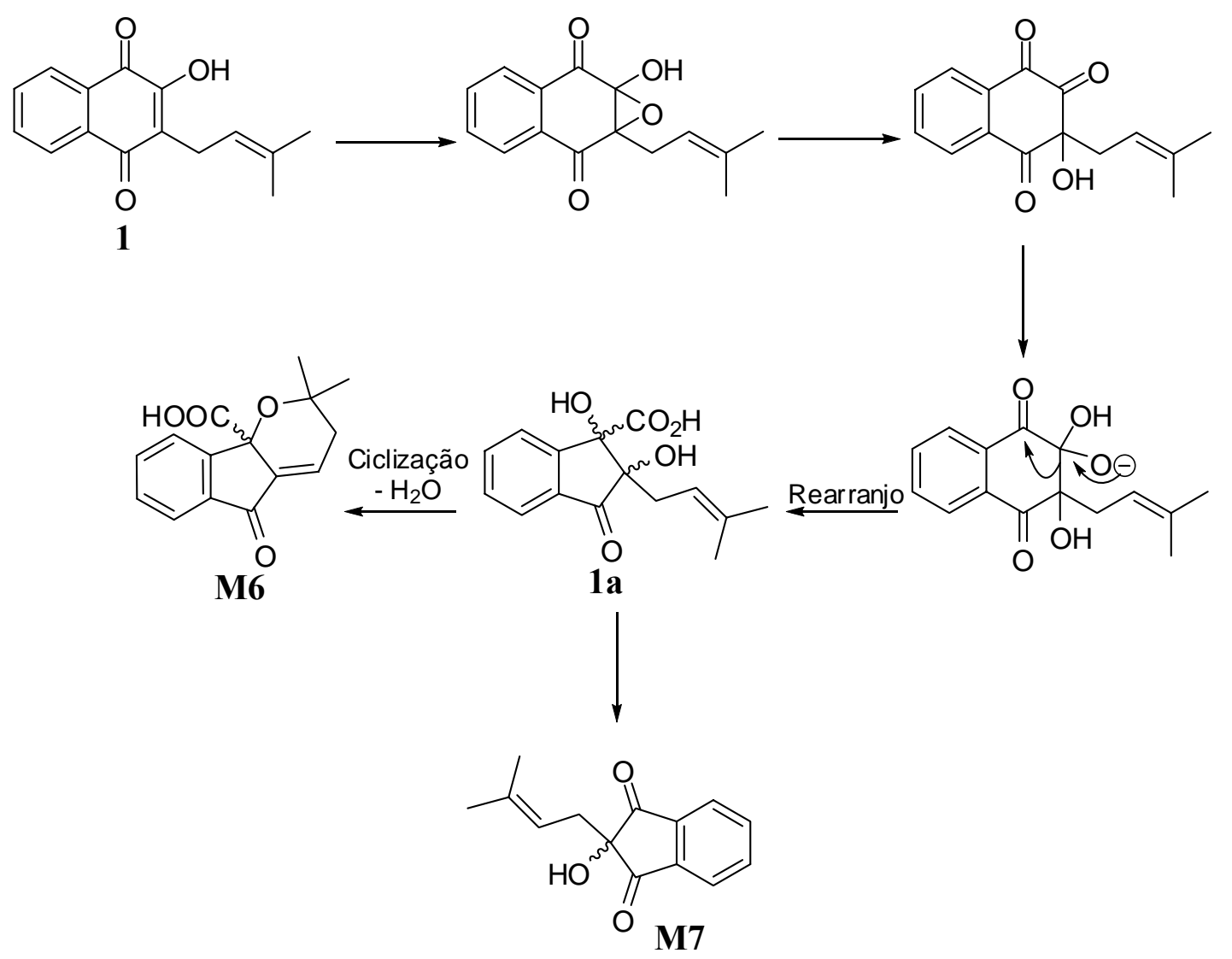

Figura 56. Produção de M6 e M7 a partir da biotransformação do lapachol (1) por $A$. brasiliensis, tendo 1a (intermediário de Hooker) como intermediário.

Dessa forma, a partir desses estudos ficou claro que, sob as condições empregadas na biotransformação do lapachol (1), esse sofreu inicialmente oxidação e posterior contração do anel quinona para formar o intermediário de Hooker (1a). A formação de M1 ocorreu a partir de ciclização e perda de água por parte de 1a. Por outro lado, M2 foi gerado quando 1a sofreu descarboxilação via um intermediário instável. 


\subsection{Avaliação da citotoxicidade dos metabólitos do lapachol obtidos por}

\section{biotransformação}

As propriedades citotóxicas das naftoquinonas, incluindo o lapachol, são bastante conhecidas, estando associadas ao estímulo do estresse oxidativo e à alquilação de nucleófilos celulares nas células tumorais (SUNASEE et al., 2013).

Objetivando-se avaliar a atividade citotóxica dos metabólitos obtidos a partir da biotransformação do lapachol, realizaram-se os ensaios de citotoxicidade frente às células tumorais mamárias SKBR3. Os mesmos metabólitos também foram avaliados frente à linhagem celular normal de fibroblastos humanos GM07402-A com o intuito de verificar a seletividade citotóxica dos mesmos. O lapachol também foi empregado nos ensaios para possibilitar os estudos comparativos. Os resultados obtidos estão apresentados na Tabela 16.

Tabela 16. Valores de $\mathrm{IC}_{50}(\mu \mathrm{M})$ apresentados pelo lapachol e seus metabólitos frente a linhagens celulares normais (GM07492-A) e tumorais (SKBR3).

\begin{tabular}{ccc}
\hline Substância & SKBR3 & GM07402-A \\
\hline Lapachol & 72,33 & 835,00 \\
M1 & 532,77 & $>1000$ \\
M2 & 10,35 & $>1000$ \\
M3 & 724,32 & $>1000$ \\
M4 & $>1000$ & $>1000$ \\
M5 & 165,50 & 184,00 \\
M6 & 895,60 & $>1000$ \\
M7 & 925,20 & $>1000$ \\
Doxorrubicina* & 0,45 & 7,00 \\
\hline controle positivo & &
\end{tabular}


A análise conjunta das estruturas químicas dos metabólitos obtidos a partir da biotransformação do lapachol (Figura 57) com os dados da Tabela 16 possibilitaram sugerir algumas características essenciais para a detecção da atividade biológica avaliada.

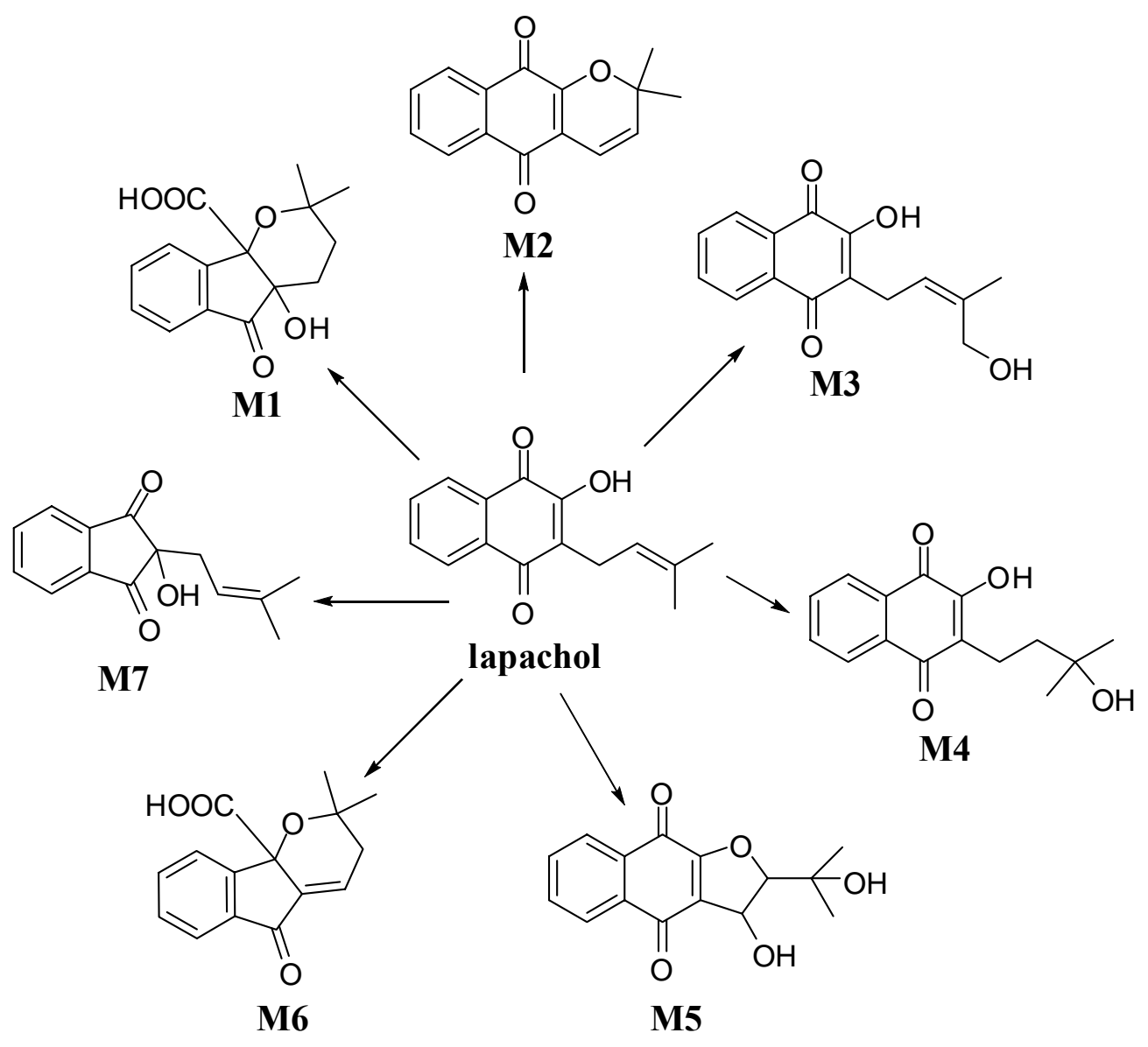

Figura 57. Metabólitos obtidos nos processos de biotransformação do lapachol por diferentes fungos filamentosos e bactérias do trato gastrointestinal.

Observa-se que a maior atividade em células tumorais mamárias foi apresentada pelo metabólito M2, $\alpha$-xiloidona, apresentando-se maior inclusive que a do lapachol. O metabólito M2 é o único que possui ligação dupla conjugada com os grupos cetônicos, mostrando a importância de tal esqueleto para o aparecimento da atividade antitumoral 
frente à linhagem tumoral testada. $O$ potencial anticâncer da $\alpha$-xiloidona também foi reportado por Garkavtsev e colaboradores, onde tal substância foi referida como possuidora de um interessante esqueleto para o desenvolvimento de fármacos anticâncer (GARKAVTSEV et al., 2011).

A importância da presença de três anéis na estrutura para o aparecimento da atividade antitumoral também foi observada quando a atividade citotóxica do metabólito M5 foi avaliada. Tal metabólito mostrou a segunda maior atividade, dentre os metabólitos, contra células tumorais mamárias.

Quando as atividades apresentadas pelos outros metabólitos que também possuem três anéis em suas estruturas, M1 e M6, foram analisadas, concluiu-se que além da estrutura cíclica, a manutenção do anel quinona também é crucial para a atividade citotóxica frente a linhagem SKBR3, uma vez que M1 e M6 praticamente não foram ativos.

Entre as substâncias com cadeia alquílica lateral alifática, observou-se que a manutenção da insaturação e dos dois grupos metílicos é imprescindível para a citotoxicidade, ou seja, na comparação com a atividade citotóxica do lapachol, observou-se o completo desaparecimento da atividade no metabólito M4 (possui cadeia alquílica saturada, devido à hidroxilação), além de grande redução da atividade do metabólito M3 (possui um grupo metílico e um hidroxi-metilênico).

Por outro lado, em relação às atividades citotóxicas frente à linhagem celular normal de fibroblastos humanos, verificou-se que alterações na cadeia alifática como hidroxilações, reduções ou ciclizações para formar o anel pirano ou tetraidropirano não alteraram a atividade citotóxica. Contrações do anel quinona e/ou perda dos grupos cetônicos também não apresentaram importância. 
O metabólito M5 foi o único metabólito que não apresentou seletividade quanto à atividade citotóxica, ou seja, a ciclização da cadeia alifática para formar o anel diidrofurano deixou o metabólito M5 tóxico para ambas as linhagens testadas.

\subsection{Estudos sobre a biotransformação da atovaquona por fungos filamentosos e bactérias do trato gastrointestinal}

A atovaquona é um agente antimicrobiano com amplo espectro de ação contra infecções parasitárias, incluindo malária, toxoplasmose e alguns tipos de pneumonia. Essa substância é seletivamente tóxica para o parasita, causando colapso das funções mitocondriais. Sendo assim, a atovaquona aparentemente causa poucos efeitos colaterais in vivo, porém outros estudos são necessários no sentido de detectar o aparecimento de toxicidade atípica (DINTER, GAJSKI e GARAJ-VRHOVAC, 2013).

Não há relatos de estudos que demonstram a metabolização da atovaquona in vitro. Em 1997, Rolan e colaboradores, objetivando a detecção de metabólitos da atovaquona, administraram o fármaco radiomarcado em voluntários e não houve detecção de metabólitos no plasma, fezes, bile ou urina. A conclusão desse estudo foi que a atovaquona não é metabolizada em humanos e, sua alta meia vida ( 2 a 3 dias) poderia ser explicada pela sua estabilidade metabólica e extensa ligação às proteínas plasmáticas (99\%) (ROLAN et al., 1997).

Os resultados sobre a biotransformação do lapachol por fungos filamentosos e bactérias do trato gastrointestinal revelaram metabólitos coincidentes com o metabolismo de mamíferos, após comparação com os dados da literatura. Já que a atovaquona é uma hidroxinaftoquinona quimicamente relacionada ao lapachol, e nunca teve nenhum metabólito identificado, iniciaram-se então os estudos sobre sua biotransformação por fungos filamentosos e bactérias do trato gastrointestinal. 
Como descrito no item 3.10 (página 35), a escolha das condições de cultivo utilizadas na biotransformação da atovaquona, baseou-se nos resultados prévios obtidos com os estudos empregando-se o lapachol. Assim, para os estudos com os fungos filamentosos, o meio de cultura utilizado foi o Koch's K1, e os fungos e o tempo de cultivo foram selecionados a partir dos mais promissores para a formação dos metabólitos do lapachol.

Dessa forma, os fungos e os tempos de cultivo selecionados para a biotransformação da atovaquona foram, respectivamente: A. brasiliensis, 24 horas; $M$. rouxii, 24 horas; C. elegans, 120 horas; C. echinulata var. elegans, 120 horas.

A biotransformação da atovaquona também foi estudada empregando-se as bactérias lácticas: L. acidophilus, Bifidobacterium sp. e cultura mista que contém $L$. acidophilus, Bifidobacterium sp. e S. salivarius subsp. thermophilus, o tempo de cultivo utilizado foi de 24 horas após a adição do substrato.

A quantidade de atovaquona utilizada em todos os casos foi de $3 \mathrm{mg}$ dissolvidos em $600 \mu \mathrm{L}$ de DMSO, quantidade determinada pelo ensaio de concentração inibitória mínima frente aos micro-organismos avaliados.

Inicialmente foram avaliados apenas um frasco tipo Erlenmeyer para cada micro-organismos. Decorrido o tempo de biotransformação, as massas miceliais ou as células bacterianas foram separadas dos caldos de cultivo, os quais foram submetidos à partição líquido-líquido com acetato de etila. As frações em acetato de etila foram analisadas por CLAE, de acordo com as condições expostas no item 3.12 (página 36), e os perfis cromatográficos estão apresentados nas Figuras a seguir. 

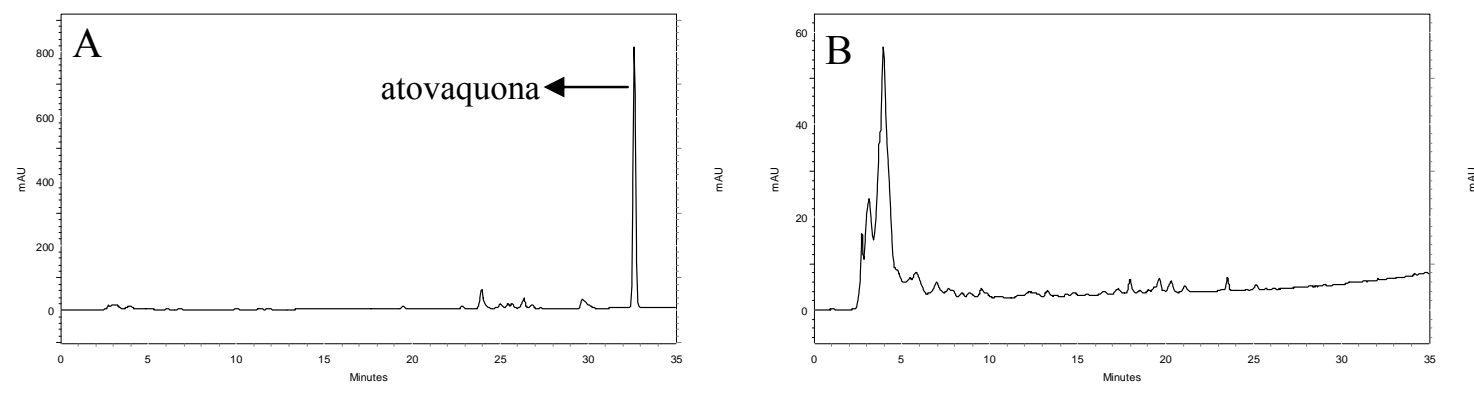

Figura 58. Cromatogramas das frações em acetato de etila dos cultivos de $A$. brasiliensis com (A) e sem atovaquona (B).
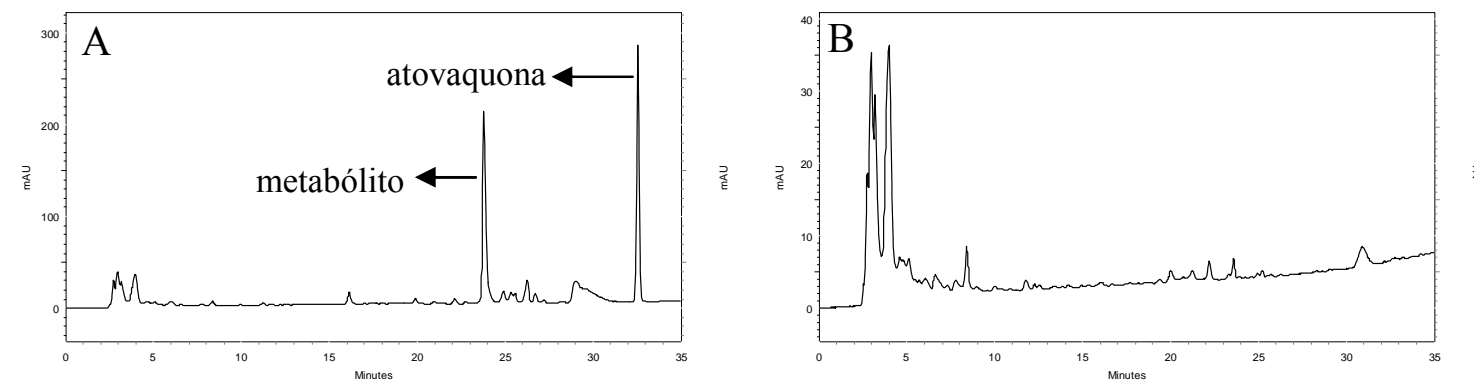

Figura 59. Cromatogramas das frações em acetato de etila dos cultivos de $M$. rouxii com (A) e sem atovaquona (B).
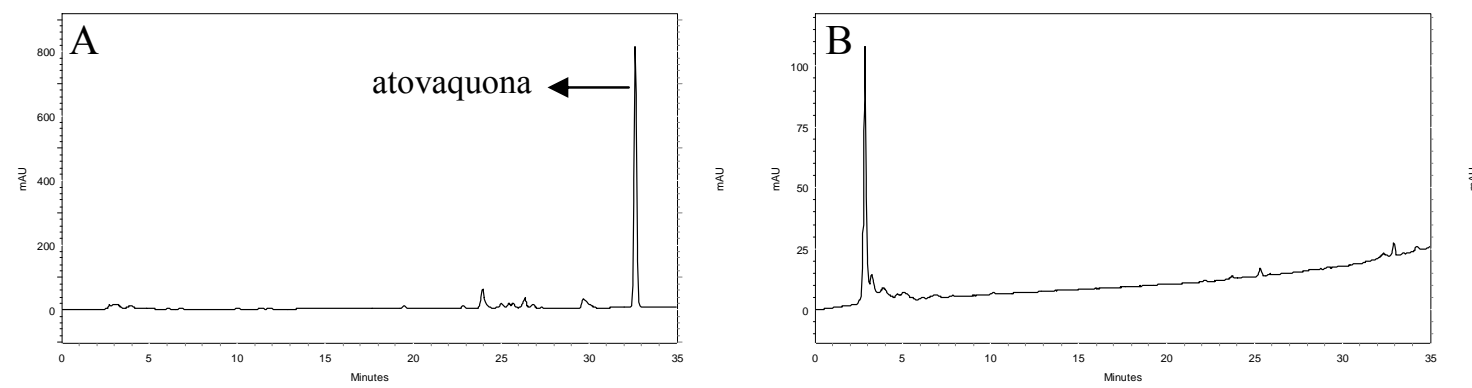

Figura 60. Cromatogramas das frações em acetato de etila dos cultivos de $C$. elegans com (A) e sem atovaquona (B).
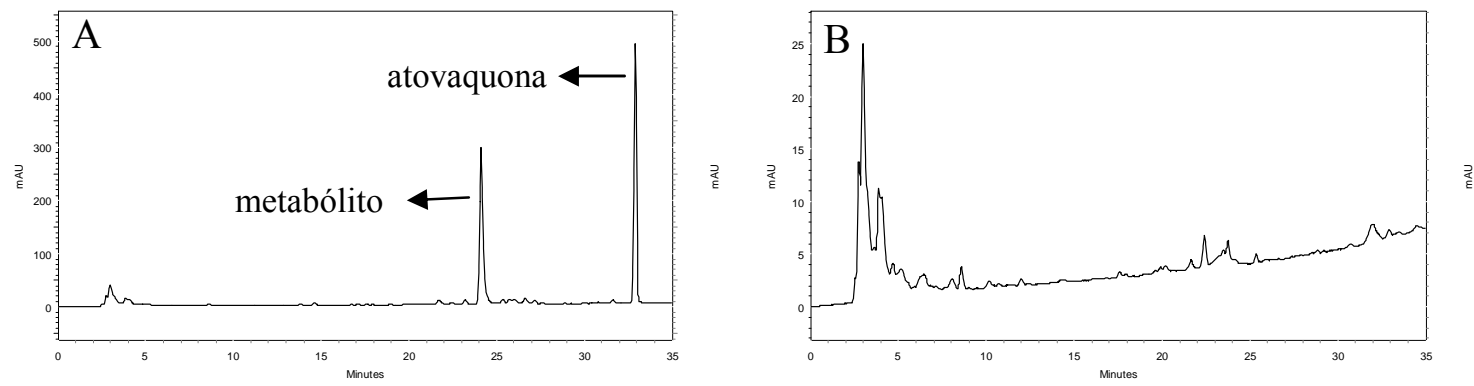

Figura 61. Cromatogramas das frações em acetato de etila dos cultivos de $C$. echinulata var. elegans com (A) e sem atovaquona (B). 

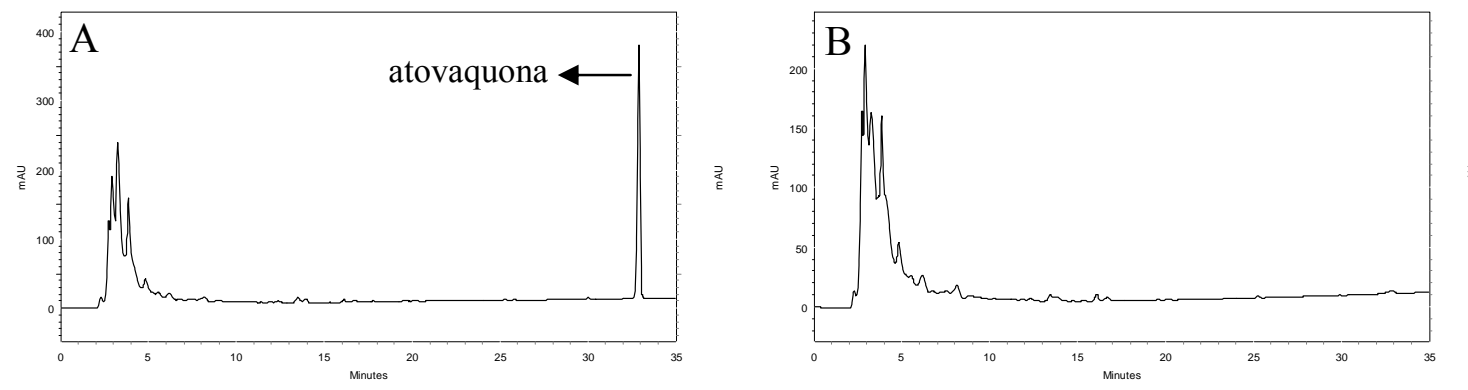

Figura 62. Cromatogramas das frações em acetato de etila dos cultivos de Bifidobacterium sp. com (A) e sem atovaquona (B).
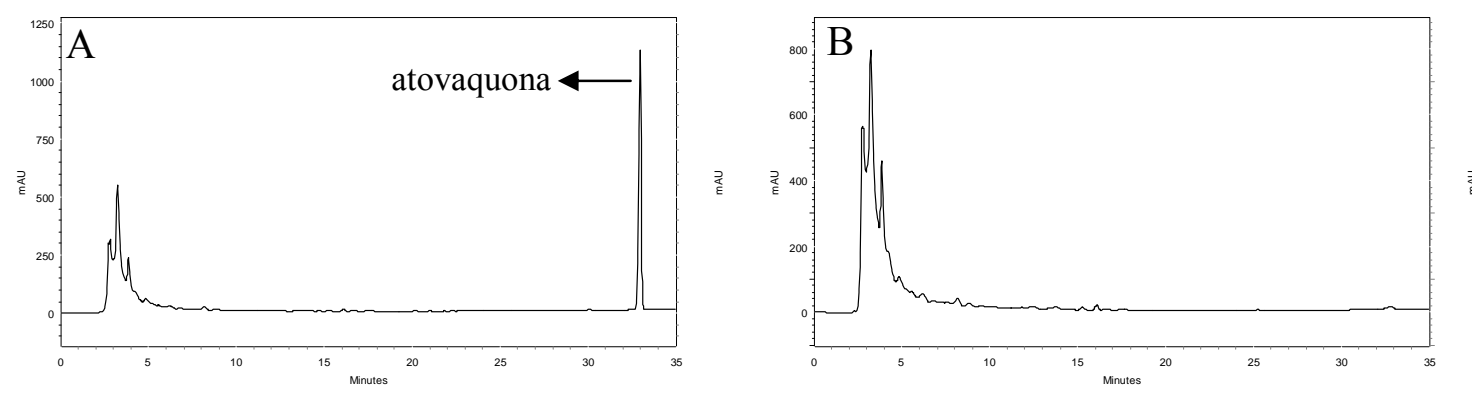

Figura 63. Cromatogramas das frações em acetato de etila dos cultivos de $L$. acidophilus com (A) e sem atovaquona (B).
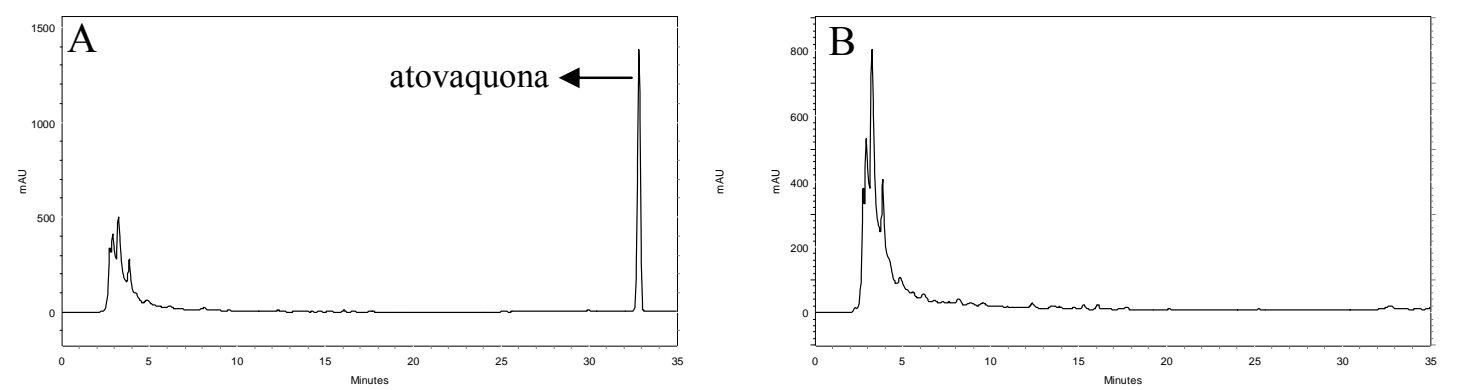

Figura 64. Cromatogramas das frações em acetato de etila dos cultivos da cultura mista de bactérias lácticas com (A) e sem atovaquona (B).

A análise dos cromatogramas mostra que de todos os micro-organismos avaliados, somente $M$. rouxii e C. echinulata var. elegans foram capazes de biotransformar a atovaquona.

Além disso, os micélios resultantes das biotransformações foram submetidos à extração com acetato de etila e analisados por CLAE, utilizando as condições descritas 
no item 3.12 (página 36), os quais mostraram que a atovaquona não foi interiorizada nem metabolizada no interior das células dos fungos filamentosos avaliados.

\subsubsection{Isolamento do metabólito da atovaquona}

Como dito anteriormente, somente dois micro-organismos foram capazes de metabolizar a atovaquona: $M$. rouxii e C. echinulata var. elegans. Assim, a escala de cultivo com C. echinulata var. elegans foi ampliada para possibilitar o isolamento do metabólito majoritário. O fungo C. echinulata var. elegans foi preferido em relação a M. rouxii porque apresentou maior rendimento na produção do metabólito.

Para isolamento de tal metabólito, a fração em acetato de etila do caldo proveniente da cultura realizada em escala ampliada foi pré-fracionada utilizando cartuchos de extração em fase sólida (SPE). Esse pré-fracionamento otimizou o procedimento de purificação, pois proporcionou a obtenção de uma fração enriquecida do metabólito, que foi então submetida a CLAE na modalidade semi-preparativa, de acordo com o item 3.14 (página 37).

O metabólito isolado foi denominado de $\mathbf{M 8}$ e foi obtido com rendimento de 5,66\%, em relação à concentração molar de atovaquona empregada na biotransformação com C. echinulata var. elegans.

\subsubsection{Identificação estrutural do metabólito M8}

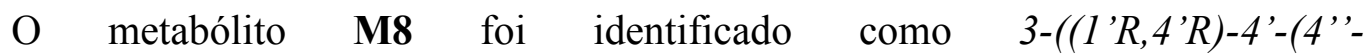
clorofenil)ciclohexil)-1,2-dioxo-diidro-1H-indeno-3-ácido carboxílico, substância inédita na literatura, e sua estrutura química está apresentada na Figura 65. 


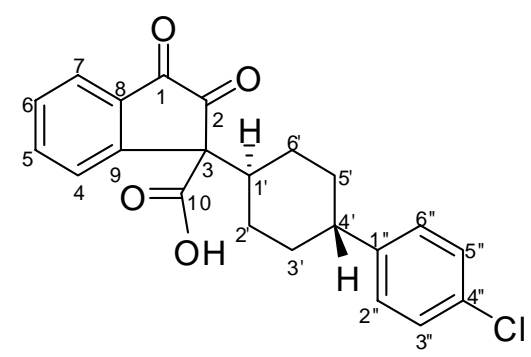

Figura 65. Estrutura química do metabólito M8.

$\mathrm{Na}$ Tabela 17 estão apresentados os deslocamentos químicos de todos os hidrogênios e carbonos, bem como suas correlações observadas no mapa de contornos de HMBC.

Tabela 17. Sinais de RMN de ${ }^{1} \mathrm{H}(500 \mathrm{MHz}),{ }^{13} \mathrm{C}(125 \mathrm{MHz})$ e $\mathrm{HMBC}$ do metabólito $\mathrm{M8}$ em $\mathrm{CD}_{3} \mathrm{OD}, \delta$ em ppm.

\begin{tabular}{|c|c|c|c|}
\hline Posição & $\delta_{\mathrm{H}}$ multiplicidade ( $\mathrm{J}$ em Hz) & $\delta_{\mathrm{C}}$ tipo & HMBC* \\
\hline 1 & - & $204,8 \mathrm{C}$ & \\
\hline 2 & - & $173,4 \mathrm{C}$ & \\
\hline 3 & - & $89,7 \mathrm{C}$ & \\
\hline 4 & $7,62 d(7,7)$ & $124,1 \mathrm{CH}$ & $3,5,9$ \\
\hline 5 & $7,53 t(7,2)$ & $130,3 \mathrm{CH}$ & 4,9 \\
\hline 6 & $7,72 m$ & $136,4 \mathrm{CH}$ & $1,5,7,8$ \\
\hline 7 & $7,72 \mathrm{~m}$ & $123,1 \mathrm{CH}$ & $1,5,6,8$ \\
\hline 8 & - & $153,3 \mathrm{C}$ & \\
\hline 9 & - & $137,6 \mathrm{C}$ & \\
\hline 10 & - & $175,8 \mathrm{C}$ & \\
\hline 1 , & $2,09 m$ & $44,1 \mathrm{CH}$ & 2 \\
\hline 2 ' & $1,38 m ; 2,26 m$ & $27,3 \mathrm{CH}_{2}$ & $4^{\prime}, 10$ \\
\hline $3^{\prime}$ & $0,42 m ; 1,44 m$ & $31,7 \mathrm{CH}_{2}$ & 2 \\
\hline 4 ' & $2,28 \mathrm{~m}$ & $44,9 \mathrm{CH}$ & $3^{\prime}, 6{ }^{\prime \prime}$ \\
\hline 5 , & $1,32 \mathrm{~m} ; 1,41 \mathrm{~m}$ & $35,3 \mathrm{CH}_{2}$ & $1 "$ \\
\hline 6 ' & $1,62 m ; 1,90 m$ & $35,4 \mathrm{CH}_{2}$ & $1^{\prime}, 2^{\prime}, 5^{\prime}$ \\
\hline $1 "$ & - & $147,3 \mathrm{C}$ & \\
\hline $2 "$ & $7,11 d(8,4)$ & $129,3 \mathrm{CH}$ & $1 ", 4 ", 6 "$ \\
\hline $3 "$ & $7,20 d(8,4)$ & $129,2 \mathrm{CH}$ & $1 ", 4 ", 6 "$ \\
\hline $4 "$ & - & $132,4 \mathrm{C}$ & \\
\hline $5 "$ & $7,20 d(8,4)$ & $129,2 \mathrm{CH}$ & $4^{\prime}, 4 "$ \\
\hline $6 "$ & $7,11 d(8,4)$ & $129,3 \mathrm{CH}$ & 4" \\
\hline
\end{tabular}

A elucidação estrutural de M8 foi realizada a partir da comparação com os deslocamentos químicos dos ${ }^{1} \mathrm{H}$ e ${ }^{13} \mathrm{C}$ da estrutura da atovaquona. Inicialmente, notou- 
se grande semelhança entre ambas as estruturas. As diferenças encontradas foram em relação aos carbonos nas posições 2 e 10. A estrutura da atovaquona possui dois grupos cetônicos nas posições 1 e 4, além de um grupo hidroxílico no carbono 3. No metabólito M8, os carbonos nas posições 1 e 2 apresentam $\delta$ 204,8 e 173,4, respectivamente, denotando a presença dos grupos cetônicos nessas posições. Além disso, o espectro de $\mathrm{RMN}$ de ${ }^{13} \mathrm{C}$ de $\mathbf{M 8}$ mostrou um carbono com deslocamento químico de 175,8 ppm, sugerindo a presença de um grupamento ácido carboxílico. A correlação heteronuclear observada entre o hidrogênio 2' e o carbono 10 possibilitou a determinação da posição do ácido carboxílico na estrutura de M8.

Análises adicionais dos espectros de ${ }^{1} \mathrm{H}$ e ${ }^{13} \mathrm{C}$, bem como dos espectros bidimensionais de M8 confirmaram que não existiam outras diferenças estruturais em relação à estrutura do substrato atovaquona.

No espectro de massas de alta resolução do metabólito M8, obtido no modo positivo, foi possível observar um pico em $\mathrm{m} / \mathrm{z} 423,0957\left[\mathrm{M}+\mathrm{H}_{2} \mathrm{O}+\mathrm{Na}\right]^{+}$consistente com a fórmula molecular proposta $\left(\mathrm{C}_{22} \mathrm{H}_{19} \mathrm{ClO}_{4}, \mathrm{~m} / z\right.$ 382,0972, calculada).

4.12.3 Avaliação da citotoxicidade do metabólito obtido a partir da biotransformação da atovaquona

As atividades citotóxicas apresentadas pelo metabólito M8 foram avaliadas frente a células tumorais mamárias SKBR3 e de fibroblastos normais humanos GM07402-A. Os resultados estão apresentados na Tabela 18. 
Tabela 18. Valores de $\mathrm{IC}_{50}(\mu \mathrm{M})$ apresentados pela atovaquona e seu metabólito frente a linhagens celulares normais (GM07492-A) e tumorais (SKBR3).

\begin{tabular}{ccc}
\hline Substância & SKBR3 & GM07402-A \\
\hline Atovaquona & 282,30 & 340,50 \\
M8 & 110,20 & 108,80 \\
Doxorrubicina* & 0,45 & 7,00 \\
\hline controle positivo & & \\
\hline
\end{tabular}

A observação dos resultados da Tabela 18, da estrutura de M8 e sua comparação com a estrutura do substrato atovaquona (Figura 66), mostraram que a transformação ocorrida no anel quinoidal da atovaquona para formar M8 causou o aumento das atividades citotóxicas não-seletivamente, ou seja, M8 foi mais tóxico que a atovaquona tanto para células tumorais quanto normais.
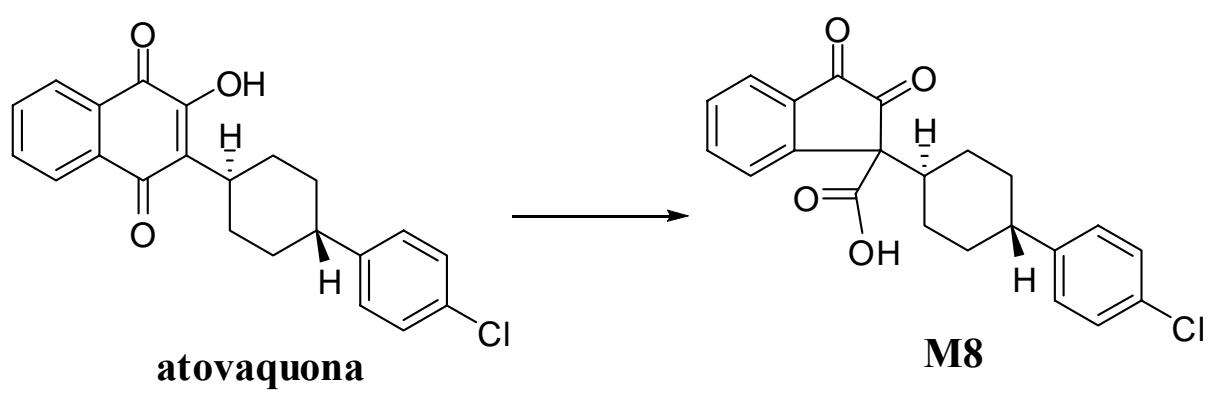

Figura 66. Produção do metabólito M8 a partir da atovaquona.

\subsection{Estudos sobre a biotransformação do isolapachol por fungos}

\section{filamentosos e bactérias do trato gastrointestinal}

Silva e colaboradores, em uma revisão sobre a biotransformação de terpenos por diferentes espécies de Mucor, discutiram como pequenas modificações na estrutura de diferentes terpenos podem favorecer ou impedir certas reações de biotransformações 
(SILVA et al., 2013). Com base nesse relato, e após a identificação de diferentes metabólitos provenientes da biotransformação do lapachol, iniciaram-se os estudos sobre a biotransformação do isolapachol.

O objetivo de empregar-se o isolapachol nos processos de biotransformação foi avaliar se a alteração da posição da insaturação da cadeia alquílica lateral exerceria algum efeito no aparecimento dos metabólitos. Assim, a biotransformação do isolapachol foi realizada utilizando-se condições idênticas às usadas para a biotransformação do lapachol.

De forma análoga ao estabelecido durante os estudos com a atovaquona, foram selecionados para biotransformar o isolapachol aqueles fungos que metabolizaram de forma satisfatória o lapachol. Portanto, os fungos e os tempos de cultivo selecionados para a biotransformação do isolapachol foram, respectivamente: A. brasiliensis, 24 horas; M. rouxii, 24 horas; C. elegans, 120 horas; C. echinulata var. elegans, 120 horas. As quantidades de isolapachol empregadas foram $3 \mathrm{mg}$ dissolvidos em $600 \mu \mathrm{L}$ de DMSO para cada Erlenmeyer utilizado, sendo que tal concentração foi determinada a partir da realização dos ensaios de concentração inibitória mínima.

Após decorrido o tempo de cultivo, as massas miceliais foram separadas dos caldos, os quais foram submetidos à partição líquido-líquido com acetato de etila. As frações obtidas foram analisadas por CLAE, de acordo com as condições analíticas descritas no item 3.12 (página 36), e os cromatogramas estão apresentados nas Figuras a seguir. 

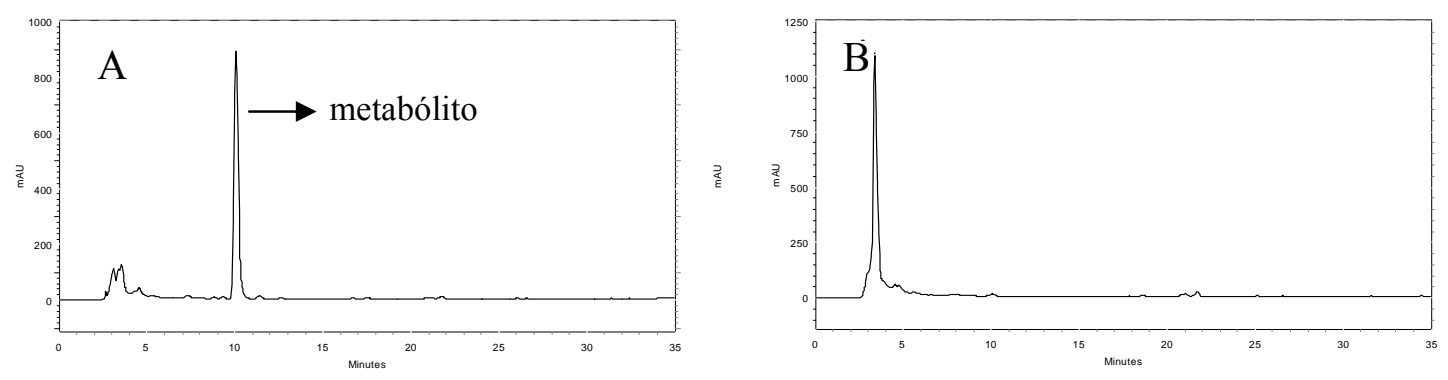

Figura 67. Cromatogramas das frações em acetato de etila dos cultivos de $A$. brasiliensis com (A) e sem isolapachol (B).
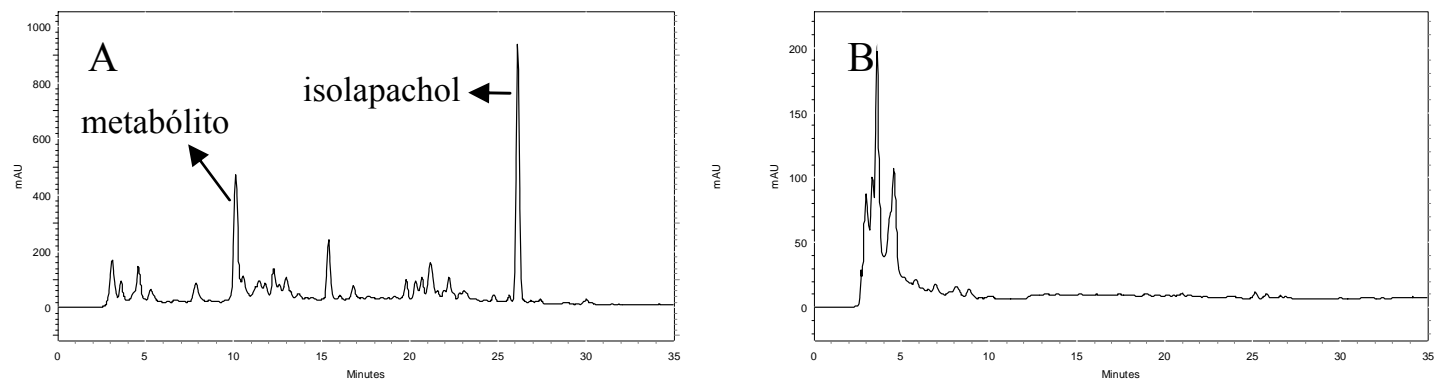

Figura 68. Cromatogramas das frações em acetato de etila dos cultivos de $M$. rouxii com (A) e sem isolapachol (B).
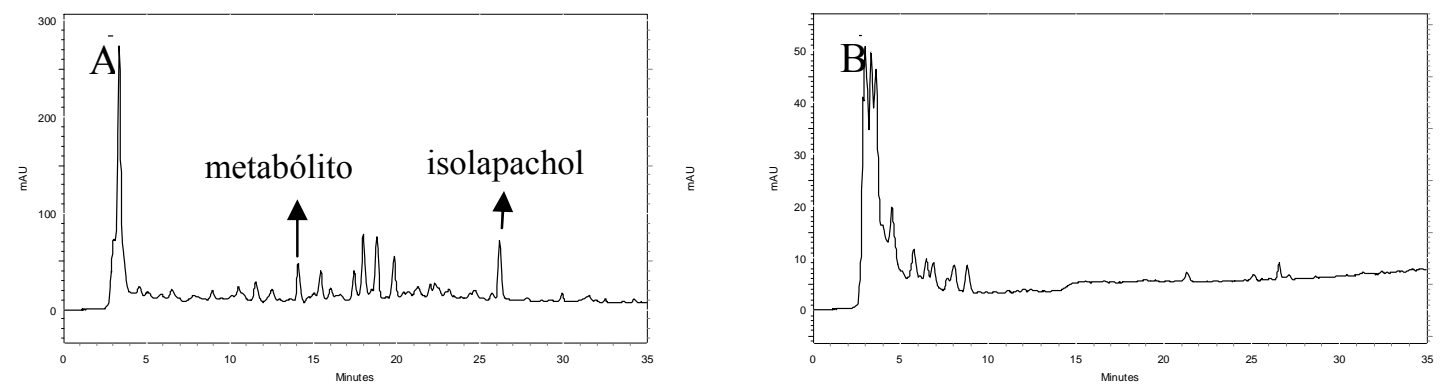

Figura 69. Cromatogramas das frações em acetato de etila dos cultivos de $C$. elegans com (A) e sem isolapachol (B).
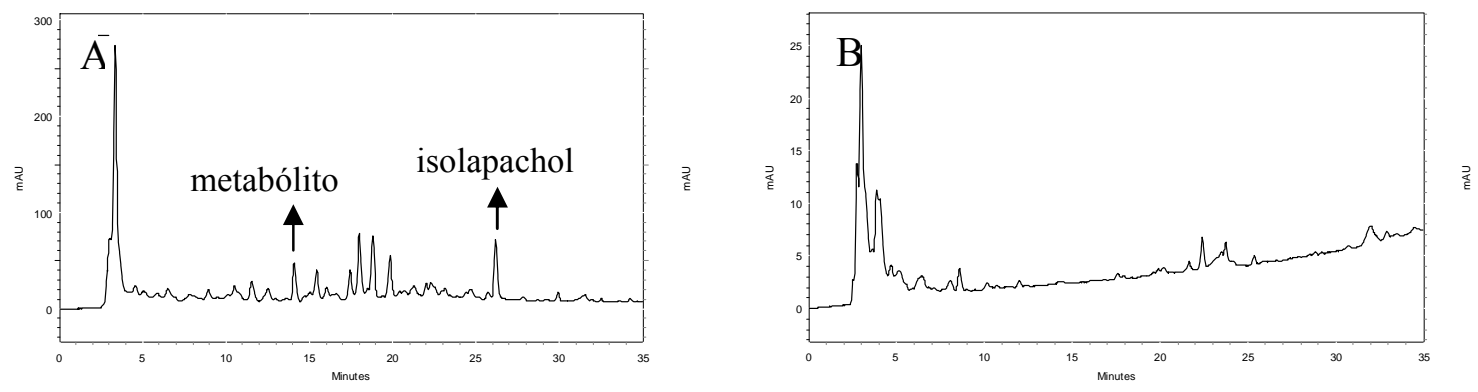

Figura 70. Cromatogramas das frações em acetato de etila dos cultivos de $C$. echinulata var. elegans com (A) e sem isolapachol (B). 
A análise dos cromatogramas apresentados possibilitou a constatação de que, em geral, a biotransformação do isolapachol não gerou metabólitos diferentes dos já identificados quando da biotransformação do lapachol. As diferenças ocorreram em relação ao rendimento dos metabólitos obtidos e ao consumo do substrato ofertado.

Assim, a comparação entre os cromatogramas obtidos das frações provenientes das biotransformações do lapachol e do isolapachol possibilitou as seguintes constatações:

1. A biotransformação por $A$. brasiliensis produziu o metabólito M1 tanto a partir do lapachol, quanto do isolapachol. Porém, observou-se que o rendimento de obtenção de M1 a partir do isolapachol foi superior;

2. A biotransformação do isolapachol por M. rouxii também produziu o mesmo metabólito já identificado durante a biotransformação do lapachol (metabólito M1). Porém todo lapachol foi consumido durante a biotransformação, diferentemente do que ocorreu com o isolapachol;

3. O emprego de duas espécies diferentes de Cunninghamella na biotransformaçção do lapachol e do isolapachol gerou a formação do mesmo metabólito M3, em todos os casos. Porém o rendimento da produção de M3 foi bastante superior quando o lapachol foi empregado como substrato.

Vale ressaltar que a inferência de que os metabólitos eram coincidentes foi feita mediante análise dos espectros de absorção no ultravioleta e realização de coinjeções em análises por CLAE.

Após a separação das massas miceliais, essas foram lavadas com água destilada, pesadas e submetidas à extração com acetato de etila. A análise de tais frações em CLAE, utilizando as condições expostas no item 3.12 (página 36), revelou 
cromatogramas nos quais observou-se que nenhum metabólito foi produzido intracelularmente

A biotransformação do isolapachol também foi investigada utilizando-se as bactérias do trato gastrointestinal: L. acidophilus, Bifidobacterium sp. e cultura mista que contém L. acidophilus, Bifidobacterium sp. e S. salivarius subsp. thermophilus, sendo o tempo de cultivo de 24 horas após a adição do substrato. Portanto, após 24 horas de cultivo as células bacterianas foram separadas dos caldos, os quais foram submetidos à partição líquido-líquido com acetato de etila. As frações obtidas foram analisadas por CLAE e os cromatogramas estão apresentados nas Figuras a seguir.
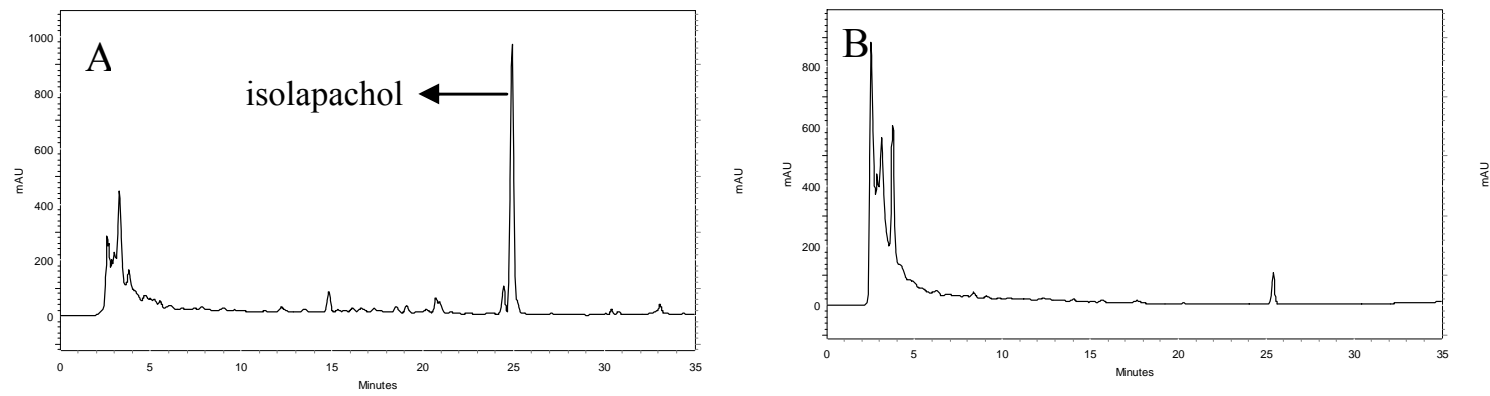

Figura 71. Cromatogramas das frações em acetato de etila dos cultivos da mistura de bactérias lácticas com (A) e sem isolapachol (B).
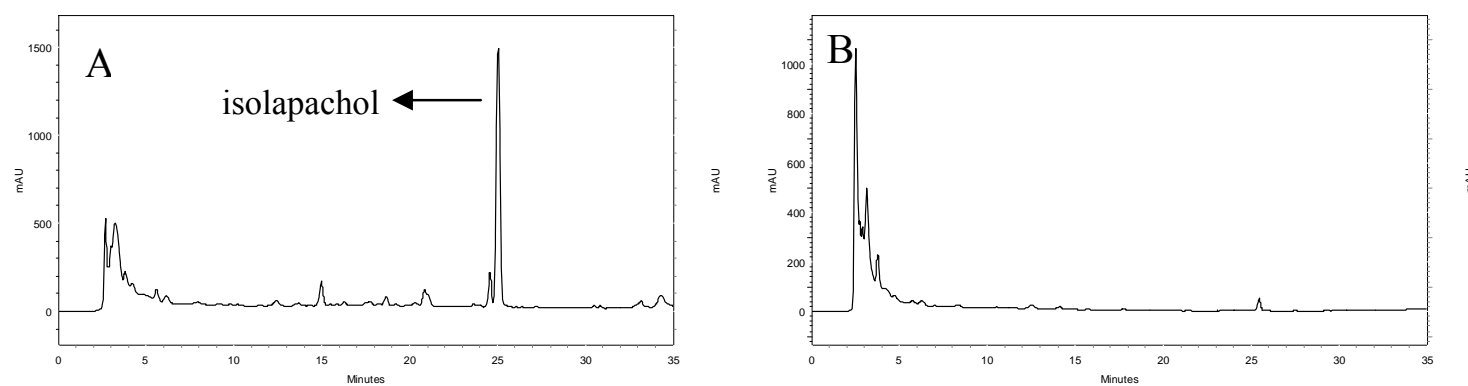

Figura 72. Cromatogramas das frações em acetato de etila dos cultivos com $L$. acidophilus com (A) e sem isolapachol (B). 

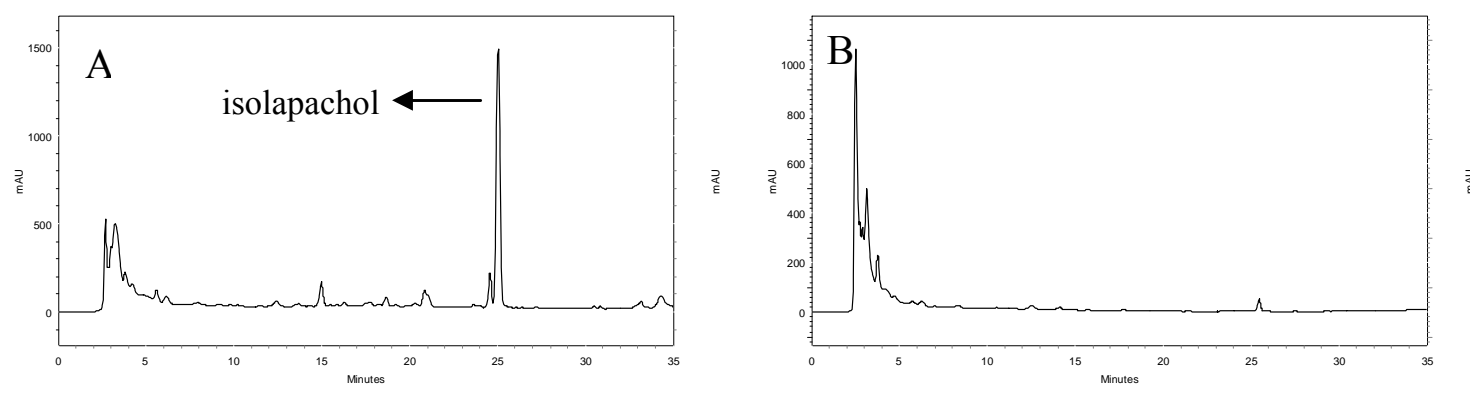

Figura 73. Cromatogramas das frações em acetato de etila dos cultivos com Bifidobacterium sp. com (A) e sem isolapachol (B).

A análise por CLAE das frações obtidas dos caldos das culturas revelou que nenhuma das bactérias lácticas foi capaz de biotransformar o isolapachol nas condições utilizadas. 


\section{Conclusões}

\section{CONCLUSÕES}

As análises dos resultados obtidos permitiram tecer inúmeras conclusões e observações que podem ser agregadas ao conhecimento sobre o metabolismo in vitro de diferentes naftoquinonas.

Os ensaios de concentração inibitória mínima foram cruciais ao permitir a utilização das concentrações máximas dos substratos, sem comprometer a viabilidade de cada micro-organismo. Outro fator que se mostrou importante para o sucesso das reações de biotransformação foi a padronização do crescimento dos micro-organismos, o que possibilitou a adição dos substratos na fase estacionária de crescimento, na qual as enzimas produzidas apresentam, em geral, menor especificidade.

As reações de biotransformação do lapachol não foram influenciadas pela solubilidade do substrato no meio aquoso, nem pelo tempo de cultivo ou pela composição do meio de cultura. Tais observações mostram que a expressão das enzimas dos micro-organismos avaliados não foi influenciada por nenhuma dessas variáveis.

Foram observadas também algumas coincidências na atividade enzimática de alguns fungos filamentosos, pois muitos deles metabolizaram o lapachol de forma semelhante, produzindo metabólitos idênticos, porém com rendimentos variáveis. A comparação desses metabólitos com os detectados no metabolismo de mamíferos mostrou o potencial de vários desses fungos em mimetizar o metabolismo catalisado pelas enzimas do citocromo P450 de mamíferos.

Durante a realização de estágio no exterior, verificou-se que fungos filamentosos pertencentes ao mesmo gênero e espécie, porém de linhagens diferentes, biotransformaram o lapachol da mesma maneira.

Objetivando-se avaliar o metabolismo intestinal in vitro do lapachol e de seu sal de potássio, bactérias do trato gastrointestinal humano foram também utilizadas nos 


\section{Conclusões}

estudos de biotransformação. A bactéria $E$. coli não foi capaz de metabolizar nenhum dos substratos. L. acidophulus e Bifidobacterium sp. foram empregados em culturas isoladas e também em culturas mistas com S. salivarius subsp. thermophilus, metabolizando o lapachol de forma diferente. Não foram observadas alterações no perfil metabólico quando a solubilidade do substrato ou o tempo de cultivo foram alterados. Esses últimos resultados mostraram que há algumas semelhanças entre os sistemas enzimáticos dos fungos filamentosos e das bactérias lácticas aqui avaliadas, uma vez que ocorreram semelhanças em alguns estudos.

Cinco metabólitos do lapachol foram isolados e suas estruturas químicas foram determinadas, sendo um deles nunca relatado na literatura. Os mesmos metabólitos foram submetidos aos ensaios de citotoxicidade frente a células tumorais e normais. Conclusões acerca da relação estrutura-atividade podem ser inferidas devido a observação de que a manutenção dos grupos cetônicos do anel quinona foi indispensável para o aparecimento das atividades citotóxicas. Atividade citotóxica mais proeminente contra células tumorais do que a exibida pelo lapachol foi observada para um dos metabólitos fruto da ciclização oxidativa da cadeia alifática.

A biotransformação do lapachol por A. brasiliensis foi estudada mais profundamente, com a determinação da cinética de produção dos metabólitos. Esse estudo possibilitou o isolamento de dois outros metabólitos e a conclusão que o fungo A. brasiliensis é capaz de transformar o lapachol da mesma forma que a oxidação de Hooker, uma importante reação em química orgânica.

Quando se analisa a literatura sobre os estudos de farmacocinética empregando a atovaquona, observa-se que nunca nenhum metabólito foi detectado e/ou identificado. No trabalho aqui descrito, foi possível isolar e determinar a estrutura química de um metabólito, cujos espectros de RMN revelaram alterações no anel quinona com 


\section{Conclusões}

formação de um grupamento ácido carboxílico. A determinação da estrutura química desse metabólito pode contribuir na elucidação do metabolismo que a atovaquona pode estar sofrendo in vivo. As atividades citotóxicas frente a células tumorais e normais mostraram que as alterações estruturais aumentaram não-seletivamente a citotoxicidade desse metabólito em comparação com a apresentada pela atovaquona.

Quando o isolapachol foi empregado nos estudos de biotransformação, foram feitas conclusões acerca da especificidade enzimática apresentada pelos fungos filamentosos e bactérias do trato gastrointestinal. Nenhuma bactéria biotransformou o isolapachol. Todos os fungos filamentosos avaliados metabolizaram o isolapachol e produziram o mesmo metabólito verificado quando o lapachol foi empregado como substrato. Todas as biotransformações do isolapachol apresentaram menor rendimento na obtenção dos metabólitos, em comparação com os mesmos experimentos realizados usando lapachol, exceto quando A. brasiliensis foi empregado. Tais observações revelam que alterações na posição da instauração da cadeia alifática de tais naftoquinonas implicam em inibições enzimáticas.

Finalmente, observou-se quão importante são os experimentos de biotransformação utilizando micro-organismos para a predição do metabolismo dos xenobióticos, bem como para a obtenção de novos esqueletos químicos e/ou moléculas biologicamente ativas. 


\section{REFERÊNCIAS BIBLIOGRÁFICAS}

AHMAD, A. L.; OH, P. C.; ABD SHUKOR, S. R. Sustainable biocatalytic synthesis of L-homophenylalanine as pharmaceutical drug precursor. Biotechnology Advances, v. 27, p. 286-296, 2009.

ALEU, J.; HANSON, J. R.; HERNANDEZ GALAN, R.; COLLADO, I. G. Biotransformation of the fungistatic sesquiterpenoids patchoulol, ginsenol, cedrol and globulol by Botrytis cinerea. Journal of Molecular Catalysis B: Enzymatic, v. 11, n. 4-6, p. 329-334, 2001.

ANDRADE-NETO, V. F.; GOULART, M. O. F.; DA SILVA FILHO, J. F.; DA SILVA, M. J.; PINTO, M. C. F. R.; PINTO, A. V.; ZALIS, M. G.; CARVALHO, L. H.; KRETTLI, A. U. Antimalarial activity of phenazines from lapachol, $\beta$-lapachone and its derivatives against Plasmodium falciparum in vitro and Plasmodium berghei in vivo. Bioorganic \& Medicinal Chemistry Letters, v. 14, n. 5, p. 1145 - 1149, 2004.

ASHA, S.; VIDYAVATHI, M. Cunninghamella - A microbial model for drug metabolism studies-A review. Biotechnology Advances, v. 27, n. 1, p. 16-29, 2009.

AUCÉLIO, R. Q.; PERÉZ-CORDOVÉS, A. I.; LIMA, J. L. X.; FERREIRA, A. B. B.; GUAS, A. M. E.; SILVA, A. R. Determination of lapachol in the presence of other naphthoquinones using 3MPA-CdTe quantum dots fluorescent probe. Spectrochimica Acta Part A: Molecular and Biomolecular Spectroscopy, v. 100, p. 155 - 160, 2013.

BACKHED, F.; LEY, R. E.; SONNENBURG, J. L.; PETERSON, D. A.; GORDON, J. I. Host bacterial mutualism in the human intestine. Science, v. 307, n. 5717, p. $1915-$ $20,2005$.

BARAMEE, A.; COPPIN, A.; MORTUAIRE, M.; PELINSKI, L.; TOMAVO, S.; BROCARD, J. Synthesis and in vitro activities of ferrocenic aminohydroxynaphthoquinones against Toxoplasma gondii and Plasmodium falciparum. Bioorganic \& Medicinal Chemistry, v. 14, n. 5, p. 1294 - 1302, 2006.

BARROSO, E.; SÁNCHEZ-PATÁN, F.; MARTÍN-ALVAREZ, P. J.; BARTOLOMÉ, B.; MORENO-ARRIBAS, M. V.; PELÁEZ, C.; REQUENA, T.; VAN DE WIELE, T.; MARTÍNEZ-CUESTA, C. M. Lactobacillus plantarum IFPL935 Favors the Initial Metabolism of Red Wine Polyphenols When Added to a Colonic Microbiota. Journal of Agricutural and Food Chemistry, v. 61, p. 10163-10172, 2013.

BARTNICKI-GARCIA, S. Control of dimorphism in Mucor by hexoses: inhibition of hyphal morphogenesis. Journal of Bacteriology, v. 96, p. 1586 - 1594, 1968.

BASIT, A. W.; LACEY, L. F. Colonic metabolism of ranitidine: implications for its delivery and absorption. International Journal of Pharmaceutics, v. 227, n. 1 - 2, p. $157-165,2001$.

CAMARA, C. A.; PINTO, A. C.; ROSA, M. A.; VARGAS, M. D. Secondary amines and unexpected 1-aza-anthraquinones from 2-methoxylapachol. Tetrahedron, v. 57, n. 47, p. $9569-9574,2001$. 
CASTELlANOS, G.; RUBEN, J.; PRIETO, J. M.; HEINRICH, M. Red Lapacho (Tabebuia impetiginosa) - A global ethnopharmacological commodity? Journal of Ethnopharmacology, v. 121, n. 1, p. 1 - 13, 2009.

CHARTERIS, W.P.; KELLY, P.M.; MORELLI, L.; COLLINS, J.K. Ingredient selection criteria for probiotic microorganisms in functional dairy foods. International Journal Dairy Technology, v. 51, n. 4, p. 123-136, 1998.

CLAVEL, T.; BORRMANNA, D.; BRAUNEA, A.; DORE, J.; BLAUT, M. Occurrence and activity of human intestinal bacteria involved in the conversion of dietary lignans. Anaerobe, v. 12, n. 3, p. $140-147,2006$.

CLSI (2006) Methods for dilution antimicrobial susceptibility tests for bacteria that grow aerobically; approved standard CLSI document M7-A7. Clinical and Laboratory Standards Institute, Wayne.

CLSI (2007) Methods for dilution antimicrobial susceptibility tests for bacteria that grow aerobically; approved standard CLSI document M11-A7. Clinical and Laboratory Standards Institute, Wayne.

CLSI (2008) Methods for dilution antimicrobial susceptibility tests for bacteria that grow aerobically; approved standard CLSI document M38-A2. Clinical and Laboratory Standards Institute, Wayne.

COLLADO, I. G.; ALEU, J.; HERNANDEZ-GALAN, R.; DURAN-PATRON, R. Botrytis Species: An Intriguing Source of Metabolites with a Wide Range of Biological Activities. Structure, Chemistry and Bioactivity of Metabolites Isolated from Botrytis Species. Current Organic Chemistry. v. 4, n. 12, p. 1261 - 1286, 2000.

COLLADO, I.G.; SÁNCHES, A.J.M.; HANSON, J.R. Fungal terpene metabolites: biosynthetic relationships and the control of the phytopathogenic fungus Botrytis cinerea. Natural Products Report. v. 24, p. 674 - 686, 2007.

COLLINS, D. O.; RUDDOCKA, P. L. D.; GRASSEA, J. C.; REYNOLDS, W. F.; REESE, P. B. Microbial transformation of cadina-4,10(15)-dien-3-one, aromadendr1(10)-en-9-one and methyl ursolate by $M$. plumbeus ATCC 4740. Phytochemistry, v. 59, p. 479 - 488, 2002.

CRAWFORD, P. W.; GROSS, J.; LAWSON, K.; CHENG, C. C.; DONG, Q.; LIU, D. F.; LUO, Y. L.; SZCZEPANKIEWICZ, B. G.; HEATHCOCK, C. H. Electrochemical properties of some biologically active quinone derivatives: furanquinones, pyridoquinones, and diplamine, a cytotoxic pyridoacridine alkaloid. Jounal of the electrochemical society, v. 144, n. 11, p. $3710-3715,1997$.

CUNHA-FILHO, M. S. S.; ESTÉVEZ-BRAUN A.; PÉREZ-SACAU, E.; ECHEZARRETA-LÓPEZ, M. M.; MARTÍNEZ-PACHECO, R.; LANDÍN, M. Light effect on the stability of b-lapachone in solution: pathways and kinetics of degradation. Journal of Pharmacy and Pharmacology, v. 63, p. 1156-1160, 2011. 
DA SILVA JÚNIOR, E. N.; DE MOURA, M. A. B. F.; PINTO, A. V.; PINTO, M. C. F. R.; DE SOUZA, M. C. V. B.; ARAÚJO, A. J.; PESSOA, C.; COSTA-LOTUFO, L. V.; MONTENEGRO, R. C.; DE MORAES, M. O.; FERREIRA, V. F.; GOULART, M. O. F. Cytotoxic, Trypanocidal Activities and Physicochemical Parameters of nor- $\beta$ Lapachone-based 1,2,3-Triazoles. Journal of the Brazilian Chemical Society, v. 20, n. 4, p. $635-643,2009$ a.

DA SILVA JÚNIOR, E. N.; PINTO, M. C. F. R.; DE MOURA, K. C. G.; DE SIMONE, C. A.; NASCIMENTO, C. J.; ANDRADE, C. K. Z.; PINTO, A. V. Hooker's 'lapachol peroxide' revisited. Tetrahedron Letters, v. 50, n. 14, p. 1575 - 1577, 2009 b.

DAVID, L.; GAYET, J. C.; VESCHAMBRE, H. Microbiological conversion of lapachol by various microorganisms. Agricultural and Biological Chemistry, v. 49, n. 9, p. 2693-2698, 1985.

DE MAN, J. D.; ROGOSA, M.; SHARPE, M. E. A medium for the cultivation of Lactobacilli. Journal of Applied Bacteriology, v. 23, p. 130 - 135, 1960.

DINTER, D.; GAJSKI, G.; GARAJ-VRHOVAC, V. An alkaline comet assay study on the antimalarial drug atovaquone in human peripheral blood lymphocytes: a study based on clinically relevant concentrations. Journal of Applied Toxicology, v. 33, p. 56 - 62, 2013.

DUAN, M.; HUANG, H.; LI, X.; CHEN, X.; ZHONG, D. Assignments of ${ }^{1} \mathrm{H}$ and ${ }^{13} \mathrm{C}$ NMR spectral data for ondansetron and its two novel metabolites, 1-hydroxyondansetron diastereoisomers. Magnetic Resonance in Chemistry, v. 44, p. 972-975, 2006.

ELAD, Y.; MALATHRAKIS, N. E.; DIK, A. J. Biological control of Botrytis-incited diseases and powdery mildews in greenhouse crops. Crop Protection. v. 15, n. 3, p. 229 - 240, 1996.

EL HAGE, S.; ANE, M.; STIGLIANI, J.; MARJORIE, M.; VIAL, H.; BAZIARDMOUYSSET, G.; PAYARD, M. Synthesis and antimalarial activity of new atovaquona derivatives. European Journal of Medicinal Chemistry, v. 44, n. 11, p. 4778 - 4782, 2009.

EYONG, K. O.; KUMAR, S. P.; KUETE, V.; FOLEFOC, G. N.; LANGMI, H.; MEYER, M. J. J.; LALL, N.; BASKARAN, S. Cobalt mediated ring contraction reaction of lapachol and initial antibacterial evaluation of naphthoquinones derived from lapachol. Medicinal Chemistry Research, v. 21, n. 8, p. 2117 - 2122, 2012.

EYONG, K. O.; EYONG, C. A.; SIDJUI, L. S.; YIMDJO, M. C.; NWEMBE, S. N.; LAMSHÖFT, M.; FOLEFOC, G. N.; SPITELLER, M.; NASTASA, V. Neurological activities of lapachol and its furano derivatives. Medicinal Chemistry Research, v. 22, n. 6, p. $2902-2911,2013$ a.

EYONG, K. O.; PUPPALA, M.; KUMAR, P. S.; LAMSHÖFT, M.; FOLEFOC, G. N.; SPITELLER, M.; BASKARAN, S. A mechanistic study on the Hooker oxidation: 
synthesis of novel indane carboxylic acid derivatives from lapachol. Organic \& Biomolecular Chemistry, v. 11, n. 3, p. 459 - 468, 2013 b.

FABBRI, A.; TRAVAGLIONE, S.; BALLAN, G.; LOIZZO, S.; FIORENTINI, C. The cytotoxic necrotizing factor 1 from $E$. coli: a janus toxin playing with cancer regulators. Toxins, v. 5, p. $1462-1$ 474, 2013.

FABER, K. Biotransformations in organic chemistry. Berlin, Springer-Verlag Berlin Heidelberg, p. 402, 1997.

FAIGLE, J. W. Drug Metabolism in the Colon Wall and Lumen. In: BIECK, P. R., ed. Colonic drug absorption and metabolism, Drugs and the Pharmaceutical Sciences, v. 60, p. 29 - 54, 1993.

FAO/WHO. (2002). Health and nutritional properties of probiotics in food including powder milk with live lactic acid bacteria. Report of a joint FAO/WHO expert consultation on evaluation of health and nutritional properties of probiotics in food including powder milk with live lactic acid bacteria

FIESER, L. F.; HARTWELL, J. L.; SELIGMAN, A. M. Concerning the mechanism of the Hooker Oxidation. Journal of the American Chemical Society, v. 58, p. 12231228, 1936.

FIESER, L. F.; FIESER, M. Naphthoquinone Antimalarials. XII. The Hooker Oxidation Reaction. Journal of the American Chemical Society, v. 70, n. 10, p. 3215-3222, 1948.

FONSECA, S. G. C.; DA SILVA, L. B. L.; CASTRO, R. F.; DE SANTANA, D. P. Validação de metodologia analítica para doseamento de soluções de lapachol por CLAE. Química Nova, v. 27, n. 1, p. 157-159, 2004.

FOSSE, C.; LE TEXIER, L.; ROY, S.; DELAFORGE, M.; GRÉGOIRE, S.; NEUWELS, M.; AZERAD, R. Parameters and mechanistic studies on the oxidative ring cleavage of synthetic heterocyclic naphthoquinones by Streptomyces strains. Applied Microbiology and Biotechnology, v. 65, p. 446-456, 2004.

FURA, A. Drug Discovery Today, v. 11, nos. 3/4, p. 133-141, 2006.

GARCÍA-GRANADOS, A.; FERNÁNDEZ, A.; GUTIÉRREZ, M. C.; MARTÍNEZ, A.; QUIRÓZ, R.; RIVAS, F.; ARIAS, J. M. Biotransformation of ent-13-epi-manoyl oxides difunctionalized at C-3 and C-12 by filamentous fungi. Phytochemistry, v. 65 , p.107-115, 2004.

GARKAVTSEV, I., CHAUHAN, V.P., WONG, H.K., MUKHOPADHYAY, A., GLICKSMAN, M.A., PETERSON, R.T., JAIN, R.K. Dehydro- $\alpha$-lapachone, a plant product with antivascular activity. Proceedings of the National Academy of Sciences, v. 108, p. 11596-11601, 2011.

GHOUMARI, H.; BENAJIBA, M.; GARCÍA-GRANADOS, A.; FERNÁNDEZ, A.; MARTÍNEZ, A.; RIVAS, F.; ARIAS, J.M. Biotransformations of ent-18-acetoxy-6- 
ketomanoyl oxides epimers at C-13 with filamentous fungi. Phytochemistry, v. 67, n. 20, p. 2294 - 2302, 2006.

GODERSKA, K.; NOWAK, J.; CZARNECKI, Z. Comparison of the growth of Lactobacillus acidophilus and Bifidobacterium bifidum species in media supplemented with selected saccharides including prebiotics. Acta Scientinarum Polonorum, Technologia Alimentaria, v.7, n. 2, p. 5-20, 2008.

GOMES, A.M.P.; MALCATA, F.X. Bifidobacterium subsp. and Lactobacillus acidophilus: biological, biochemical, technological and therapeutical properties relevant for use as probiotics. Trends in Food Science \& Technology, v. 10, p. 139 - 157, 1999.

GOULART, M. O. F.; LIMA, N. M. F.; SANT'ANA, A. E. G.; FERRAZ, P. A. L.; CAVALCANTI, J. C. M.; FALKOWSKI, P.; OSSOWSKI, T.; LIWO, A. Electrochemical studies of isolapachol with emphasis on oxygen interaction with its radical anions. Journal of Electroanalytical Chemistry, v. 566, n. 1, p. 25 - 29, 2004.

GUAN, S.; HE, J.; YOUNG, J. C.; ZHU, H.; LI, X. Z.; JI, C.; ZHOU, T. Transformation of trichothecene mycotoxins by microorganisms from fish digesta. Aquaculture, v. 290, n. 3 - 4, p. $290-295,2009$.

HAEBERLIN, B.; FRIEND, D. R. Anatomy and physiology of the gastrointestinal tract: implications for colonic drug delivery. In: FRIEND, D. R. ed. Oral colon-specific drug delivery, p. 1- 43, 1992.

HAHN, V.; SÜNWOLDT, K.; MIKOLASCH, A.; SCHAUER, F. Two different primary oxidation mechanisms during biotransformation of thymol by gram-positive bacteria of the genera Nocardia and Mycobacterium. Applied Microbiology and Biotechnology, v. 97, p. 1289 - 1297, 2013.

HAN, L.; HUANG, X.; DAHSE, H. M.; MOELLMANN, U.; FU, H.; GRABLEY, S.; SATTLER, I.; LIN, W. Unusual Naphthoquinone Derivatives from the Twigs of Avicennia marina. Journal of Natural Products, v. 70, p. 923 - 927, 2007.

HANSON, J.R. An introduction to biotransformations in organic chemistry. Oxford, W. H. Freeman Spektrum, p. 92, 1995.

HILÁRIO, V. C.; CARRÃO, D. B.; BARTH, T.; BORGES, K. B.; FURTADO, N. A. J. C.; PUPO, M. T.; DE OLIVEIRA, A. R. M. Assessment of the stereoselective fungal biotransformation of albendazole and its analysis by HPLC in polar organic mode. Journal of Pharmaceutical and Biomedical Analysis, v. 61, p. 100-107, 2012.

HOLLMANN, M.; RAZZAZI-FAZELI, E.; GRAJEWSKI, J.; TWARUZEK, M.; SULYOK, M.; BÖHM, J. Detection of 3-nitropropionic acid and cytotoxicity in $M$. circinelloides. Mycotoxin Research, v. 24, n. 3, p. 140 - 150, 2008.

HUISMAN, G. W.; GRAY, D. Towards novel processes for the finechemical and pharmaceutical industries. Current Opinion in Biotechnology, v. 13, n. 4, p. 352 $358,2002$. 
HUSSAIN, H.; KROHN, K.; AHMAD, V. U.; MIANA, G. A.; GREEND, I. R. Lapachol: an overview. Arkivoc, v. 2, p. 145 - 171, 2007.

ILETT, K. F.; TEE, L. B. G.; REEVES, P. T.; MINCHIN, R. F. Metabolism of drugs and other xenobiotics in the gut lumen and wall. Pharmacology and Therapeutics, v. 46, n. 1, p. 67-93, 1990.

ITO, C.; KATSUNO, S.; KONDO, Y.; TAN, H. T. W.; FURUKAWA, H. Chemical Constituents of Avicennia alba. Isolation and Structural Elucidation of New Naphthoquinones and Their Analogues, Chemical and Pharmaceutical Bulletin v. 48, n. 3, p. $339-343,2000$.

ITOIGAWAA, M.; ITO, C.; TAN, H. T. W.; OKUDAD, M.; TOKUDAD, H.; NISHINOD, H.; FURUKAWA, H. Cancer chemopreventive activity of naphthoquinones and their analogs from Avicennia plants. Cancer Letters, v. 174, p. $135-139,2001$.

JACKSON, M.; KARWOSWSKI, J. P.; HUMPHREY, P. E.; KOHL, W. L.; BARLOW, G.J.; TANAKA, S. K. Calbistrins, novel antifungal agents produced by Penicillium restrictum. The journal of Antibiotics, v. 46, n. 1, p. 34-38, 1993.

JARVIS, W.R. Pathology. In: Botryotinia and Botrytis Species: Taxonomy, Physiology, and Pathogenicity. Canada Department of Agriculture, (Monografia), Ottawa, n. 15, p.62, 1977.

JESUs L. I.; AlBUQUeRQUE, N. C. P.; BORGES, K. B.; SIMÕES, R. A.; CALIXTO, L. A.; FURTADO, N. A. J. C.; GAITANI, C. M.; PUPO, M. T.; DE OLIVEIRA, A. R. M. Enantioselective fungal biotransformation of risperidone in liquid culture medium by capillary electrophoresis and hollow fiber liquid-phase microextraction. Electrophoresis, v. 32, p. 2765-2775, 2011.

KANDIOLLER, W.; BALSANO, E.; MEIER, S. M.; JUNGWIRTH, U.; GÖSCHL, S.; ROLLER, A.; JAKUPEC, M. A.; BERGER, W.; KEPPLERAB, B. K.; HARTINGER, C. G. Organometallic anticancer complexes of lapachol: metal centre-dependent formation of reactive oxygen species and correlation with cytotoxicity. Chemical Communications, v. 49, n. 32, p. 3348 - 3350, 2013.

KAPADIA, G. J.; AZUINE, M. A.; BALASUBRAMANIAN, V.; SRIDHAR, R. Aminonaphthoquinones - a novel class of compounds with potent antimalarial activity against Plasmodium falciparum. Pharmacological Research, v. 43, n. 4, p. 363 - 36, 2001 .

KELLY, S. L.; KELLY, D. E. Microbial cytochromes P450: biodiversity and biotechnology. Where do cytochromes P450 come from, what do they do and what can they do for us? Philosophical Transactions of the Royal Society, B: Biological Sciences, v. 368, p. 1612, 2013.

KESSL, J. J.; MOSKALEV, N. V.; GRIBBLE, G. W.; NASR, M.; MESHNICK, S. R.; TRUMPOWER, B. L. Parameters determining the relative efficacy of hydroxy- 
naphthoquinone inhibitors of the cytochrome bc1 complex. Biochimica et Biophysica Acta, Bioenergetics, v. 1767, n. 4, p. 319 - 326, 2007.

KHATTAB, A. A.; ABD-EL SALAM, I. S. Construction of new mutants of $M$. racemosus to improve progesterone biotransformation. Australian Journal of Basic and Applied Sciences, v. 6, p. 356-363, 2012.

KOVACIC, P.; SOMANATHAN, R. Recent developments in the mechanism of anticancer agents based on electron transfer, reactive oxygen species and oxidative stress. Anti-Cancer Agents in Medicinal Chemistry, v. 11, n. 7, p. 658 - 668, 2011.

KOYAMA, J.; MORITA, I.; TAGAHARA, K.; OSAKAI, T.; HOTTA, H.; YANG, M. X.; MUKAINAKA, T.; NISHINO, H.; TOKUDA, H. Correlation with redox potentials and inhibitory effects on Epstein-Barr virus activation of azaanthraquinones. Chemical and Pharmaceutical Bulletin, v. 49, n. 9, p. 1214 - 1216, 2001.

KUMAR, R. S.; ROYMON, M. G.; IPE, A. J. Isolation, biochemical and molecular characterization of strains of coliforms from the water sample collected from Shivnath River. Recent Research in Science and Technology, v. 5, n. 2, p. 57 - 63, 2013.

KUTRZEBA, L. M.; KARAMYAN, V. T.; SPETH, R. C.; WILLIAMSON, J. S.; ZJAWIONY, J. K. In vitro studies on metabolism of salvinorin A. Pharmaceutical Biology, v. 47, n. 11, p. $1078-1084,2009$.

LANDA, P.; KUTIL, Z.; TEMML, V.; MALIK, J.; KOKOSKA, L.; WIDOWITZ, U.; PRIBYLOVA, M.; DVORAKOVA, M.; MARSIK, P.; SCHUSTER, D.; BAUER, R.; VANEK, T. Inhibition of in vitro leukotriene B4 biosynthesis in human neutrophil granulocytes and docking studies of natural quinines. Natural Product Communications, v. 8, n. 1, p. $105-108,2013$.

LEE, Y. R.; LEE, W. K. Efficient Synthesis of Biologically Interesting Dehydro- $\alpha-$ lapachone and $\alpha$-Lapachone. Synthetic Communications, v. 34, n. 24, p. $4537-4543$, 2004.

LEE, K.; TURNBULL, P.; MOORE, H. W. Concerning the Mechanism of the Hooker Oxidation. Journal of Organic Chemistry, v. 60, n. 2, p. $461-464,1995$.

LEMOS, T. L. G.; MONTE, F. J. Q.; SANTOS, A. K. L.; FONSECA, A. M.; SANTOS, H. S.; OLIVEIRA, M. F.; COSTA, S. M. O.; PESSOA, O. D. L.; BRAZFILHO, R. Quinones from plants of northeastern Brazil: structural diversity, chemical transformations, NMR data and biological activities. Natural Product Research, v. 21, n. 6, p. $529-550,2007$.

LERESCHE, J.E.; MEYER, H.P. Chemocatalysis and Biocatalysis (Biotransformation): Some Thoughts of a Chemist and of a Biotechnologist. Organic Process Research \& Development, v. 10, p. 572 - 580, 2006.

LIMA, N. M. F.; CORREIA, C. S.; LEON, L. L.; MACHADO, G. M.; MADEIRA, M. F.; SANT'ANA, A. E. G.; GOULART, M. O. F. Antileishmanial activity of lapachol 
and analogues against Leishmania braziliensis and Leishmania amazonensis. Memorias do Instituto Oswaldo Cruz, v. 99, n. 7, p. 757-761, 2004.

LIMA, N. M. F.; DOS SANTOS, A. F.; PORFÍRIO, Z.; GOULART, M. O. F.; SANT'ANA, A. E. G. Toxicity of lapachol and isolapachol and their potassium salts against Biomphalaria glabrata, Schistosoma mansoni cercariae, Artemia salina and Tilapia nilótica. Acta Tropica, v. 83 p. 43 - 47, 2002.

LISOWSKA, K.; SZEMRAJ, J.; ROZALSKA, S.; DLUGONSKI, J. The expression of cytochrome P-450 and cytochrome P-450 reductase genes in the simultaneous transformation of corticosteroids and phenanthrene by Cunninghamella elegans. FEMS Microbiology Letters, v. 261, n. 2, p. 175 - 180, 2006.

LÜBBEHÜSEN, T. L.; NIELSEN, J.; MCINTYRE, M. Morphology and physiology of the dimorphic fungus Mucor circinelloides_(syn._M. racemosus) during anaerobic growth. Mycological Research, v. 107, n. 2, p. 223 - 230, 2003.

MA, X. C.; WU, L. J.; GUO, D. A. Microbial transformation of dehydrocostuslactone by Mucor polymorphosporus. Journal of Asian Natural Products Research, v. 8, n. 8, p. $713-718,2006$.

MA, L.; LIU, X.; LIANG, J.; ZHANG, Z. Biotransformations of cinnamaldehyde, cinnamic acid and acetophenone with Mucor. World Journal of Microbiology \& Biotechnology, v. 27, n. 9, p. 2133 - 2137, 2011.

MAEDA, M.; MURAKAMI, M.; TAKEGAMI, T.; OTA, T. Promotion or suppression of experimental metastasis of B16 melanoma cells after oral administration of lapachol. Toxicology and Applied Pharmacology, v. 229, n. 2, p. 232 - 238, 2008.

MARSHALL, V. P.; MCGOVREN, J. P.; RICHARD, F. A.; RICHARD, R. E.; WILEY, P. F. Microbial metabolism of anthracycline antibiotics daunomycin and adriamycin. The Journal of Antibiotics, v. 31, p. 336-342, 1978.

MARTINEZ, M. J. A.; BENITO, P. B. Biological activity of quinones. Studies in Natural Products Chemistry, v. 30, p. 303-366, 2005.

MECA, G.; RITIENI, A.; MAÑES, J. Reduction in vitro of the minor Fusarium mycotoxin beauvericin employing different strains of probiotic bactéria. Food Control, v. 28, n. 2 , p. $435-440,2012$.

MESELHY, M. R.; KADOTA, S.; TSUBONO, K.; HATTORI, M.; NAMBA, T. Biotransformation of Shikonin by Human Intestinal Bacteria. Tetrahedron, v. 50, n. 10, p. 3081-3098, 1994.

MOIR, M., THOMSON, R.H. Naphthaquinones in Lomatia species. Phytochemistry, v. 12, p. 1351-1353, 1973. 
NASIRI, H. R.; BOLTE, M.; SCHWALBE, H. Electrochemical and crystal structural analysis of alpha- and dehydro-alpha-lapachones. Natural Product Research, v. 22, n. 14, p. $1225-1230,2008$.

NETTO-FERREIRA, J. C.; LHIAUBET-VALLET, V.; DA SILVA, A. R.; DA SILVA,A. M.; FERREIRA, A. B. B.; MIRANDA, M. A. The photochemical reactivity of triplet $\beta$-lapachone-3-sulfonic acid towards biological substrates. Jounal of the Brazilian Chemical Society, v. 21, n. 6, p. 966 - 972, 2010.

NIEHUES, M.; BARROS, V. P.; EMERY, F. S.; DIAS-BARUFFI, M.; ASSIS, M. D.; LOPES, N. P. Biomimetic in vitro oxidation of lapachol: A model to predict and analyse the in vivo phase I metabolism of bioactive compounds. European Journal of Medicinal Chemistry, v. 54, p. $804-812,2012$.

NIXON, G. L.; MOSS, D. M.; SHONE, A. E.; LALLOO, D. G.; FISHER, N.; O'NEILL, P. M.; WARD, S. A.; BIAGINI, G. A. Antimalarial pharmacology and therapeutics of atovaquona. Journal of Antimicrobial Chemotherapy, v. 68, n. 5, p. $977-985,2013$.

OliveIRA, M. F.; LEMOS, T. L. G.; DE MATTOS, M. C.; SEGUNDO, T. A.; SANTIAGO, G. M. P.; BRAZ-FILHO, R. New enamine derivatives of lapachol and biological activity. Anais da Academia Brasileira de Ciências, v. 74, n. 2, p. 211-221, 2002.

OSSOWSKI, T.; GOULART, M. O. F.; ABREU, F. C.; SANT'ANA, A. E. G.; MIRANDA, P. R. B.; COSTA, C. O.; LIWO, A.; FALKOWSKI, P.; ZARZECZANSKA, B. Determination of the pKa values of some biologically active and inactive hydroxyquinones. Journal of Brazilian Chemical Society, v. 19, n. 1, p. $175-183,2008$.

OTTEN, S. L.; ROSAZZA, J. P. Microbial transformations of natural antitumor agents. 17. Conversions of lapachol by Cunninghamella echinulata. Journal of Natural Products, v. 44, n. 5, p. 562-568, 1981

PARRILHA, G. L.; VIEIRA, R. P.; CAMPOS, P. P.; SILVA, G. D. F.; DUARTE, L. P.; ANDRADE, S. P.; BERALDO, H. Coordination of lapachol to bismuth(III) improves its anti-inflammatory and anti-angiogenic activities. BioMetals, v. 25, n. 1, p. $55-62,2012$.

PATEL, R.N. Microbial/enzymatic synthesis of chiral intermediates for pharmaceuticals. Enzyme and Microbial Technology, v. 31, p. 804-826, 2002.

PAVIA, D. L.; LAMPMAN, G. M.; KRIZ, G. S.; VYVYAN, J. R. Introdução à Espectroscopia. Editora Cengage Learning, 4ed, 2010.

PEL, H.J.; WINDE, J.H., ARCHER, D.B., et al. Genome sequencing and analysis of the versatile cell factory Aspergillus niger CBS 513.88. Nature Biotechnology, v. 25, p. 221-231, 2007. 
PERVAIZ, S. A.; MADNI, M. A.; AHMAD, H.; KHALIQ, F. H. Microbial biotransformation: a tool for drug designing. Applied Biochemistry and Microbiology, v. 49, n. 5, p. 437-450, 2013.

POLAINO, S.; GONZALEZ-DELGADO, J.A.; ARTEAGA, P.; HERRADOR, M.M.; BARRERO, A. F.; CERDA-OLMEDO, E. Apocarotenoids in the sexual interaction of Phycomyces blakesleeanus. Organic \& Biomolecular Chemistry, v. 10, p. $3002-3009,2012$.

QI-HE, C., JING, L.; HAI-FENG, Z.; GUO-QING, H.; MING-LIANG, F. The betulinic acid production from betulin through biotransformation by fungi. Enzyme and Microbial Technology, v. 45, n. 3, p. 175 - 180, 2009.

RAIMONDI, S.; RONCAGLIA, L.; LUCIA, M. AMARETTI, A.; LEONARDI, A.; PAGNONI, U. M.; ROSSI, M. Bioconversion of soy isoflavones daidzin and daidzein by Bifidobacterium strains. Applied Microbiology Biotechnology, v. 81, p. 943 - 950, 2009.

RAO, K. T. Quinone natural products. Streptonigrin (NSC-4583) and lapachol (NSC11905) structure-activity relations. Cancer Chemotherapy Reports, Part 2, v. 4, n. 4, p. $11-17,1974$.

RIBEIRO, C.M.R.; SOUZA, P.P.; FERREIRA, L.L.D.M; PINTO, L.A.; ALMEIDA, L.S.; JESUS, J.G. Ciclização do lapachol induzida por sais de tálio III. Química Nova, v. 31, n. 4, p.759-762, 2008.

ROBINSON, T.; SINGH, D.; NIGAM, P. Solid-state fermentation: a promising microbial technology for secondary metabolite production. Microbiol Biotechnology, v. 55 , p. $284-289,2001$.

ROLAN, P. E.; MERCER, A. J.; TATE, E.; BENJAMIN, I.; POSNER, J. Disposition of Atovaquona in Humans. Antimicrobial Agents and Chemotherapy, v. 41, n. 6, p. $1319-1321,1997$.

RUIZ-HERRERA, J. (1993) Dimorphism in Mucor species. In: HV Bossche, FC Odds $\&$ D Kerridge (eds) Dimorphic fungi in biology and medicine (pp 257-265). Springer, United States.

SALAS, C.; TAPIA, R. A.; CIUDAD, K.; ARMSTRONG, V.; ORELLANA, M.; KEMMERLING, U.; FERREIRA, J.; MAYDA, J. D.; MORELLO, A. Trypanosoma cruzi: activities of lapachol and alpha- and beta-lapachone derivatives against epimastigote and trypomastigote forms. Bioorganic \& Medicinal Chemistry, v. 16, n. 2, p. $668-674,2008$.

SALUSTIANO, E. J.; NETTO, C. D.; FERNANDES, R. F.; DA SILVA, A. J.; BACELAR, T. S.; CASTRO, C. P.; BUARQUE, C. D.; MAIA, R. C.; RUMJANEK, V. M..; COSTA, P. R. Comparison of the cytotoxic effect of lapachol, $\alpha$-lapachone and pentacyclic 1,4-naphthoquinones on human leukemic cells. New Drugs, v. 28, n. 2, p. $139-144,2009$. 
SASAKI, J.; MIZOUE, K.; MORIMOTO, S.; ADACHI, T.; OMURA, S. Microbial transformation of 6-o-methylerythromycin derivatives. The Journal of Antibiotics, v. 41, p. 908-915, 1988.

SEVERIANO, M. E.; SIMÃO, M. R.; RAMOS, H. P.; PARREIRA, R. L. T.; ARAKAWA, N. S.; SAID, S.; FURTADO, N. A. J. C.; DE OLIVEIRA, D. C. R.; GREGÓRIO, L. E.; TIRAPELLI, C. R.; VENEZIANI, R. C. S.; AMBRÓSIO, S. R. Biotransformation of ent-pimaradienoic acid by cell cultures of Aspergillus niger. Bioorganic and Medicinal Chemistry, v. 21, p. 5870-5875, 2013.

SIlVA, E. O.; FURTADO, N. A. J. C.; ALEU, J.; COLlADO, I. G. Terpenoid biotransformations by Mucor species. Phytochemistry reviews, v. 12, p. 857-876, 2013.

SILVA, T. M.; CAMARA, C. A.; BARBOSA, T. P.; SOARES, A. Z.; DA CUNHA, L. C.; PINTO, A. C.; VARGAS, M. D. Molluscicidal activity of synthetic lapachol amino and hydrogentaed derivatives. Bioorganic \& medicinal chemistry, v. 13, n. 1, p. $193-$ 196, 2005.

SINGER, A. C.; CROWLEY, D. E.; THOMPSON, I. P. Secondary plant metabolites in phytoremediation and biotransformation. Trends in Biotechnology, v. 21, p. 123 - 129, 2003.

SMITH, R. V.; ROSAZZA, J. P. Microbial models of mammalian metabolism. Archives of Biochemistry and Biophysics, v. 161, n. 2, p. 551-558, 1974.

SOUSA, T.; PATERSON, R.; MOORE, V.; CARLSSON, A.; ABRAHAMSSON, B.; BASIT, A. The gastrointestinal microbiota as a site for the biotransformation of drugs. International Journal of Pharmaceutics, V. 363, n. 1 - 2, p. 1 - 25, 2008.

SRISILAM, K.; VEERESHAM, C. Biotransformation of drugs by microbial cultures for predicting mammalian drug metabolism. Biotechnology Advances, v. 21, p. 3-39, 2003.

STAATS, M.; VAN BAARLEN, P.; VAN KAN, J. A. L. Molecular phylogeny of the plant pathogenic genus Botrytis and the evolution of host specificity. Molecular Biology and Evolution, v. 22, n. 2, p. 333 - 346, 2005.

STEINERT, J.; KHALAF, H.; RIMPLER, M. HPLC separation and determination of naphtho[2,3-b]furan-4,9-diones and related compounds in extracts of Tabebuia avellanedae (Bignoniaceae). Journal of Chromatography A, v. 693, p. 281 - 287, 1995.

SUBRAMANIAN, S.; FERREIRA,M. M. C.; TRSIC, M. A. Structure-Activity Relationship Study of Lapachol and Some Derivatives of 1,4-Naphthoquinones Against Carcinosarcoma Walker 256. Structural Chemistry, v. 9, n. 1, p. 47 - 57, 1998.

SUNASSEE, S. N.; VEALE, C. G. L.; SHUNMOOGAM-GOUNDEN, N.; OSONIYI, O.; HENDRICKS, D. T.; CAIRA, M. R.; DE LA MARE, J.; EDKINS, A. L.; PINTO, A. V.; DA SILVA JÚNIOR, E. N.; DAVIES-COLEMAN, M. T. Cytotoxicity of 
lapachol, $\beta$-lapachone and related synthetic 1,4-naphthoquinones against oesophageal cancer cells. European journal of medicinal chemistry, v. 62, p. 98 - 110, 2013.

THEODULOZ, C.; CARRIÓN, I. B.; PERTINO, M. W.; VALENZUELA, D.; SCHMEDA-HIRSCHMANN, G. Potential Gastroprotective effect of novel cyperenoic acid/quinone derivatives in human cell cultures. Planta Medica, v. 78, n. 17, p. 1807 $1812,2012$.

TONHOLO, J.; FREITAS, L. R; ABREU, F. C.; AZEVEDO, D. C.; ZANI, C. L.; OLIVEIRA, A. B.; GOULART, M. O. F. Eletrochemical properties of biologically active heterocyclic naphtoquinones. Jounal of the Brazilian Chemical Society, v. 9, n. 2, p. $163-169,1998$.

VAN DER MOOTER, G.; KINGET, R. Oral-colon-specific drug delivery: a review, Drug delivery, v. 2, p. 81 - 93, 1995.

VANHAECKE, L.; VERCRUYSSE, F.; BOON, N.; VERSTRAETE, W.; CLEENWERCK, I.; DE WACHTER, M.; DE VOS, P.; VAN DE WIELE, T. Isolation and characterization of human intestinal bacteria capable of transforming the dietary carcinogen 2-amino-1-methyl-6-phenylimidazo[4,5-b]pyridine. Applied and Environmental Microbiology, v. 74, n. 5, p. 1469 - 1477, 2008.

VENISETTY, R. K.; CIDDI, V. Application of microbial biotransformation for the new drug discovery using natural drugs as substrates. Current Pharmaceutical Biotechnology, v. 4, n. 153-167, 2003.

VESSECCHI, R; EMERY, F. S.; GALEMBECKC, S. E.; LOPES, N. P. Gas-phase reactivity of 2-hydroxy-1,4-naphthoquinones: a computational and mass spectrometry study of lapachol congeners. Journal of Mass Spectrometry, v. 47, p. 1648 - 1659, 2012.

WANG, M.; LITING, Z.; YANBING, S.; YINHU, M.; YU, Z.; JIANMEI, L. Effects of hydroxypropyl- $\beta$-cyclodextrin on steroids 1-en-dehydrogenation biotransformation by Arthrobacter simplex TCCC 11037. Journal of Molecular Catalysis B: Enzymatic, v. 59 , p. $58-63,2009$.

YANG, L.; CHU, J. S.; FIX, J. A. Colon-specific drug delivery: new approaches and in vitro/in vivo evaluation. International Journal of Pharmaceutics, v. 235, n. 1 - 2, p. 1 $-15,2002$.

YOUNG, J. C.; ZHOU, T.; YU, H.; ZHU, H.; GONG, J. Degradation of trichothecene mycotoxins by chicken intestinal microbes. Food and Chemical Toxicology, v. 45, n. 1, p. $136-143,2007$.

ZHAN, J.; GUO, H.; DAI, J.; ZHANG, Y.; GUO, D. Biotransformation of gastrodin by Mucor spinosus. Journal of Chinese Pharmaceutical Sciences, v. 10, p.187-189, 2001. 
ZHOU, J.; DUAN, L.; CHEN, H.; REN, X.I; ZHANG, Z.; ZHOU, F.; LIU, J.; PEI, D.; DING, K. Atovaquona derivatives as potent cytotoxic and apoptosis inducing agents.

Bioorganic \& Medicinal Chemistry Letters, v. 19, n. 17, p. 5091 - 5094, 2009. 


\section{APÊNDICES}

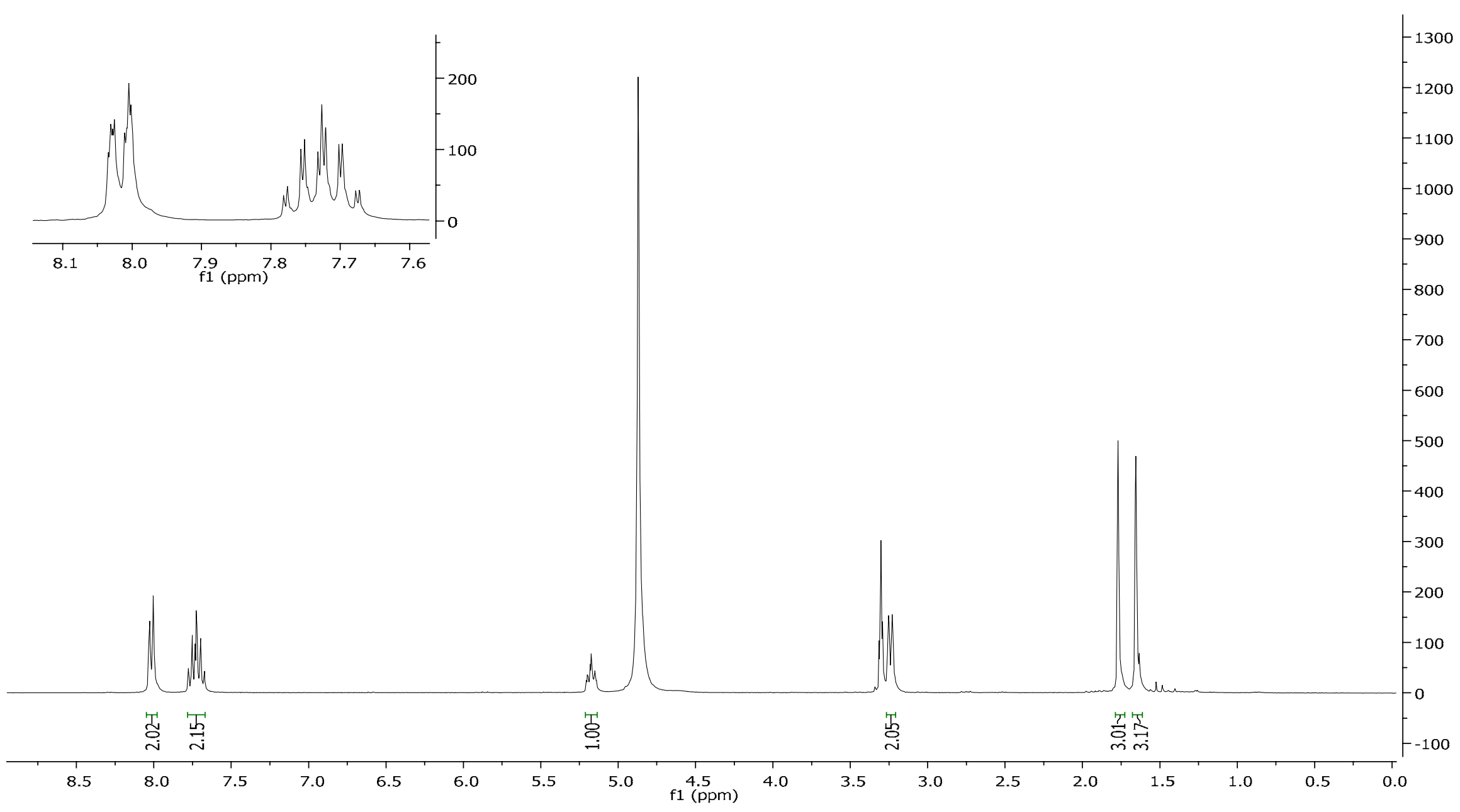

Figura A1. Espectro de RMN de ${ }^{1} \mathrm{H}$ do lapachol (500 MHz, $\mathrm{CD}_{3} \mathrm{OD}$ ) 


\section{Apêndices}

\begin{tabular}{|c|c|c|}
\hline 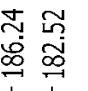 & $\begin{array}{l}\text { ને } \\
\text { 号 }\end{array}$ & 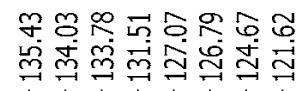 \\
\hline & 1 & $\rightarrow 1 \mapsto$ \\
\hline
\end{tabular}
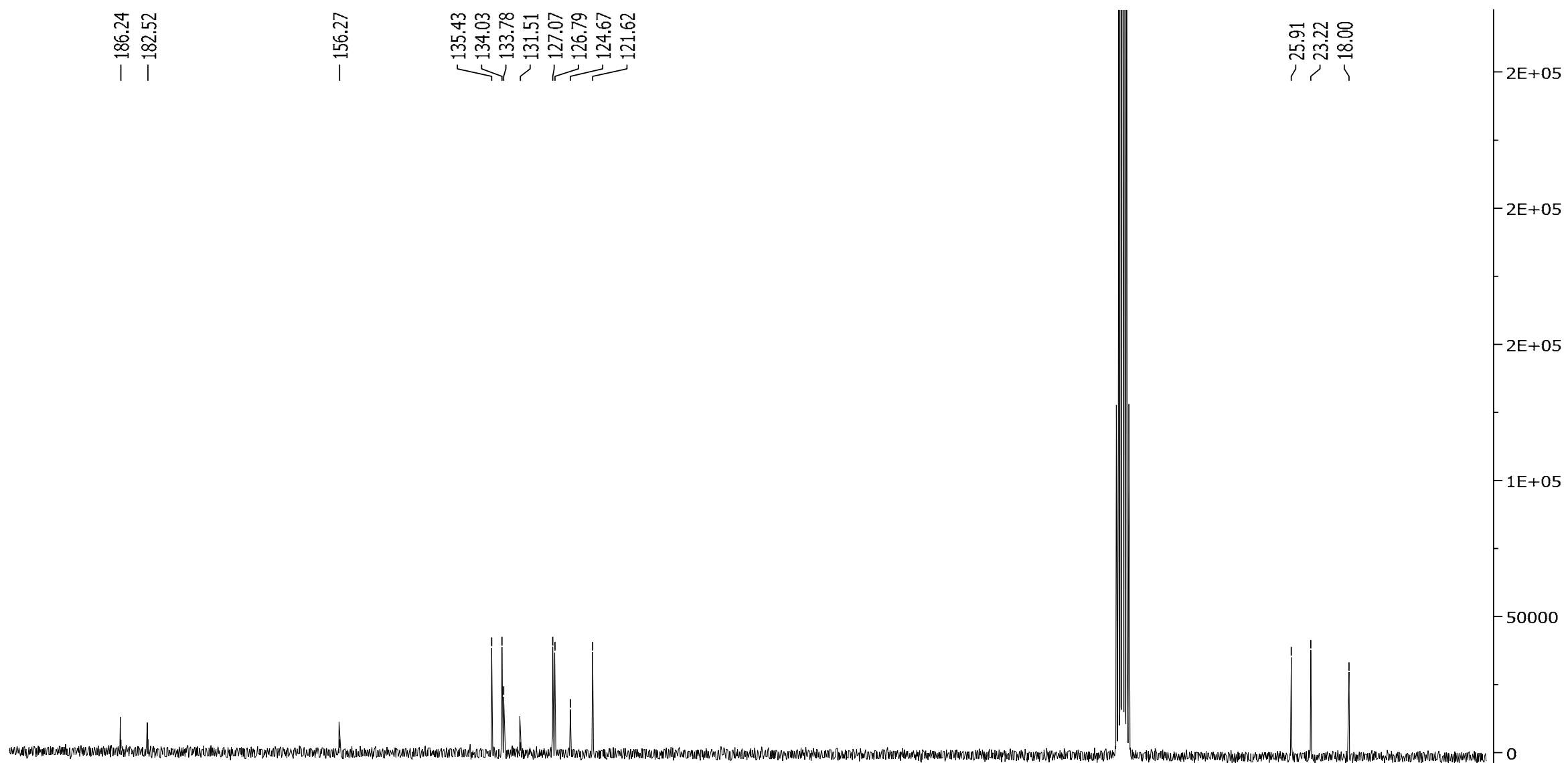

200

180

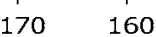

150

140

120

$110 \quad 100$

90

80

60

$50 \quad 40$

Figura A2. Espectro de RMN de ${ }^{13} \mathrm{C}$ do lapachol (125 MHz, $\left.\mathrm{CD}_{3} \mathrm{OD}\right)$ 


\section{Apêndices}
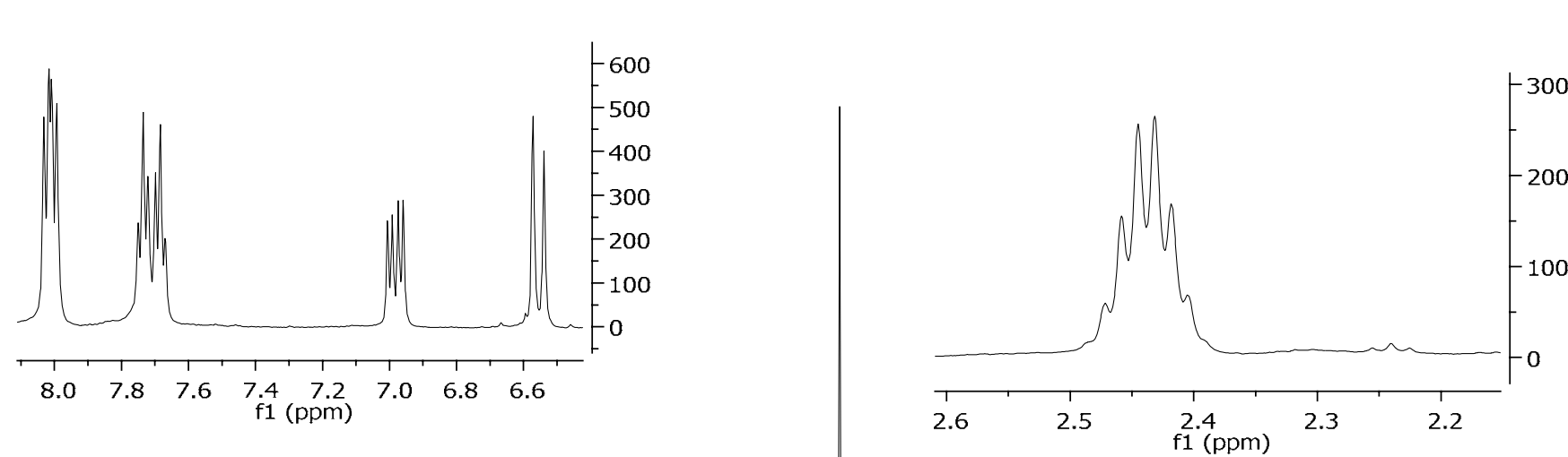

14000

13000

12000

11000

10000

9000

8000

7000

6000

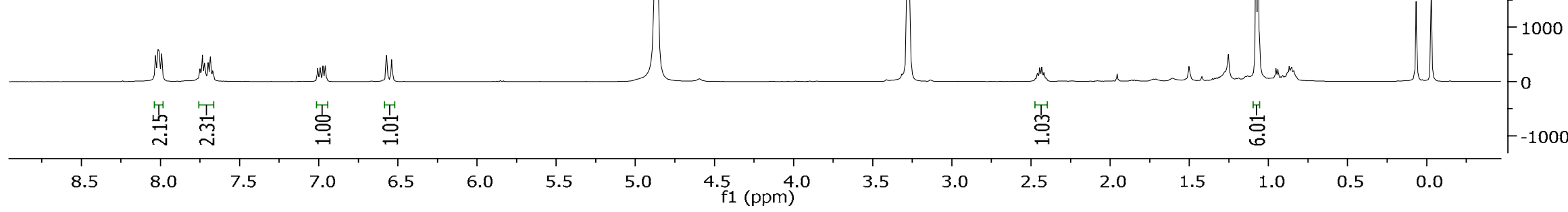

Figura A3. Espectro de $\mathrm{RMN}$ de ${ }^{1} \mathrm{H}$ do isolapachol (500 $\mathrm{MHz}, \mathrm{CD}_{3} \mathrm{OD}$ ) 


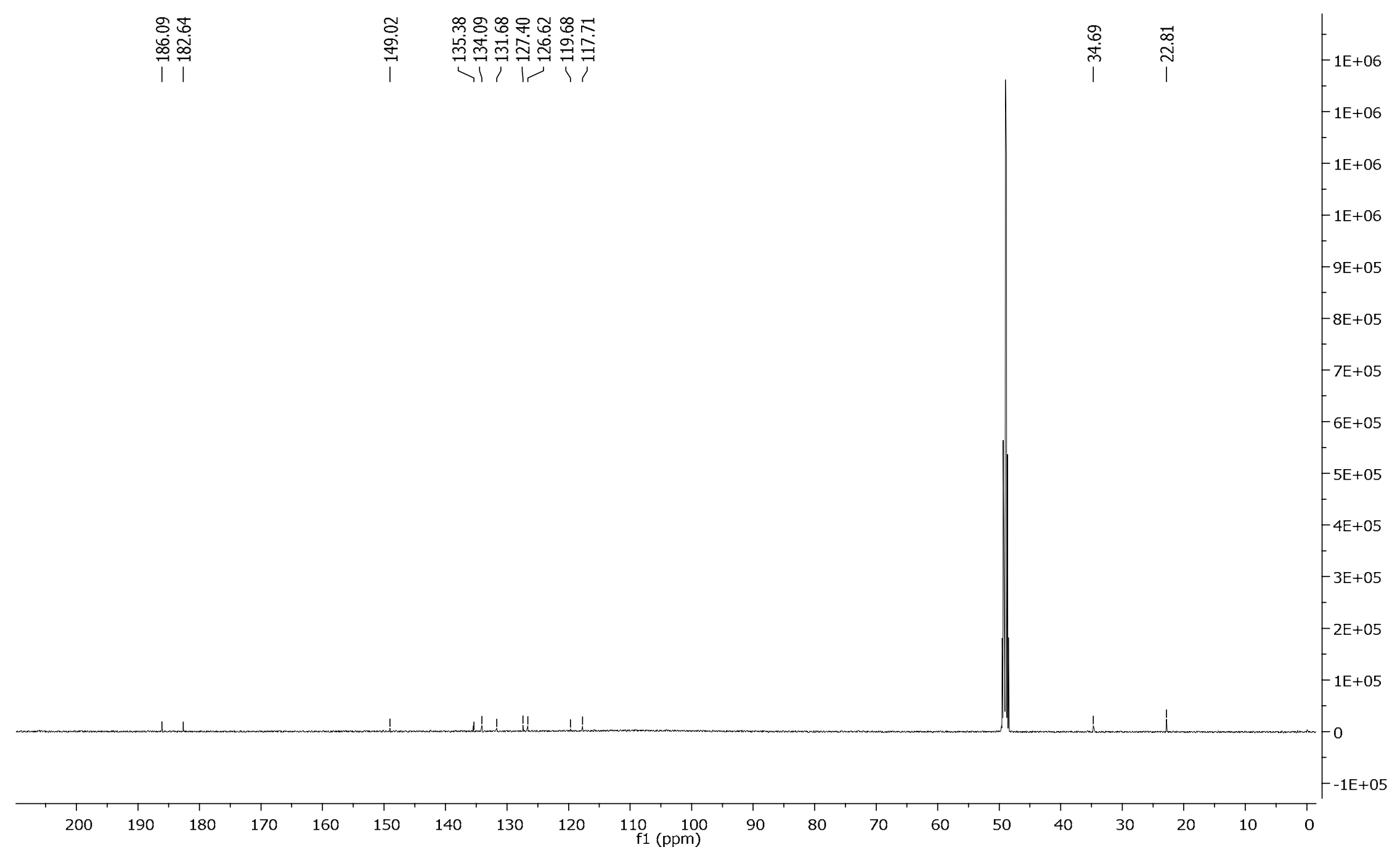

Figura A4. Espectro de $\mathrm{RMN}$ de ${ }^{13} \mathrm{C}$ do isolapachol $\left(125 \mathrm{MHz}, \mathrm{CD}_{3} \mathrm{OD}\right)$ 

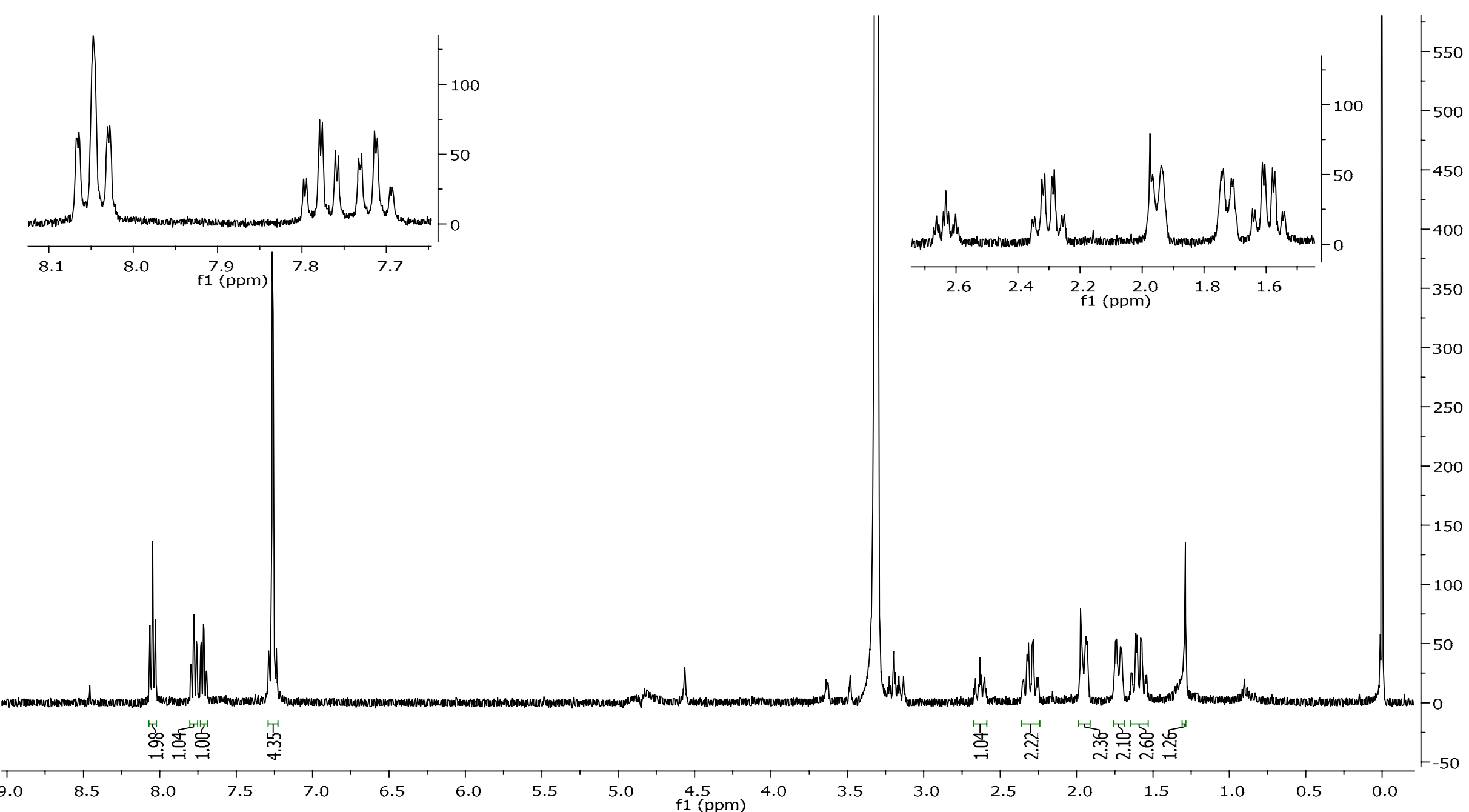

Figura A5. Espectro de $\mathrm{RMN}$ de ${ }^{1} \mathrm{H}$ da atovaquona (500 $\mathrm{MHz}, \mathrm{CD}_{3} \mathrm{OD}$ ) 


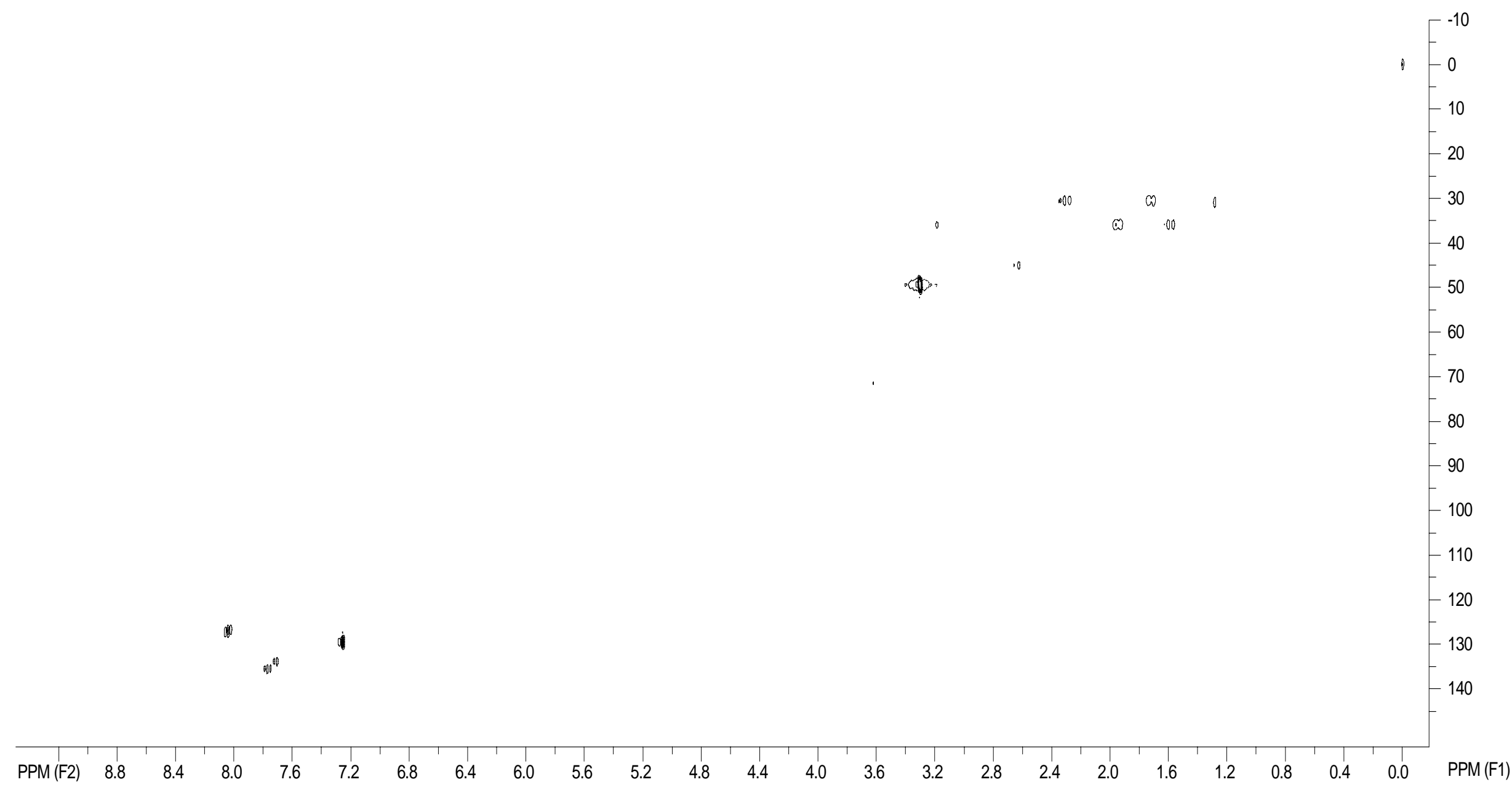

Figura A6. Mapa de contornos de HMQC da atovaquona (500 MHz, $\mathrm{CD}_{3} \mathrm{OD}$ ) 


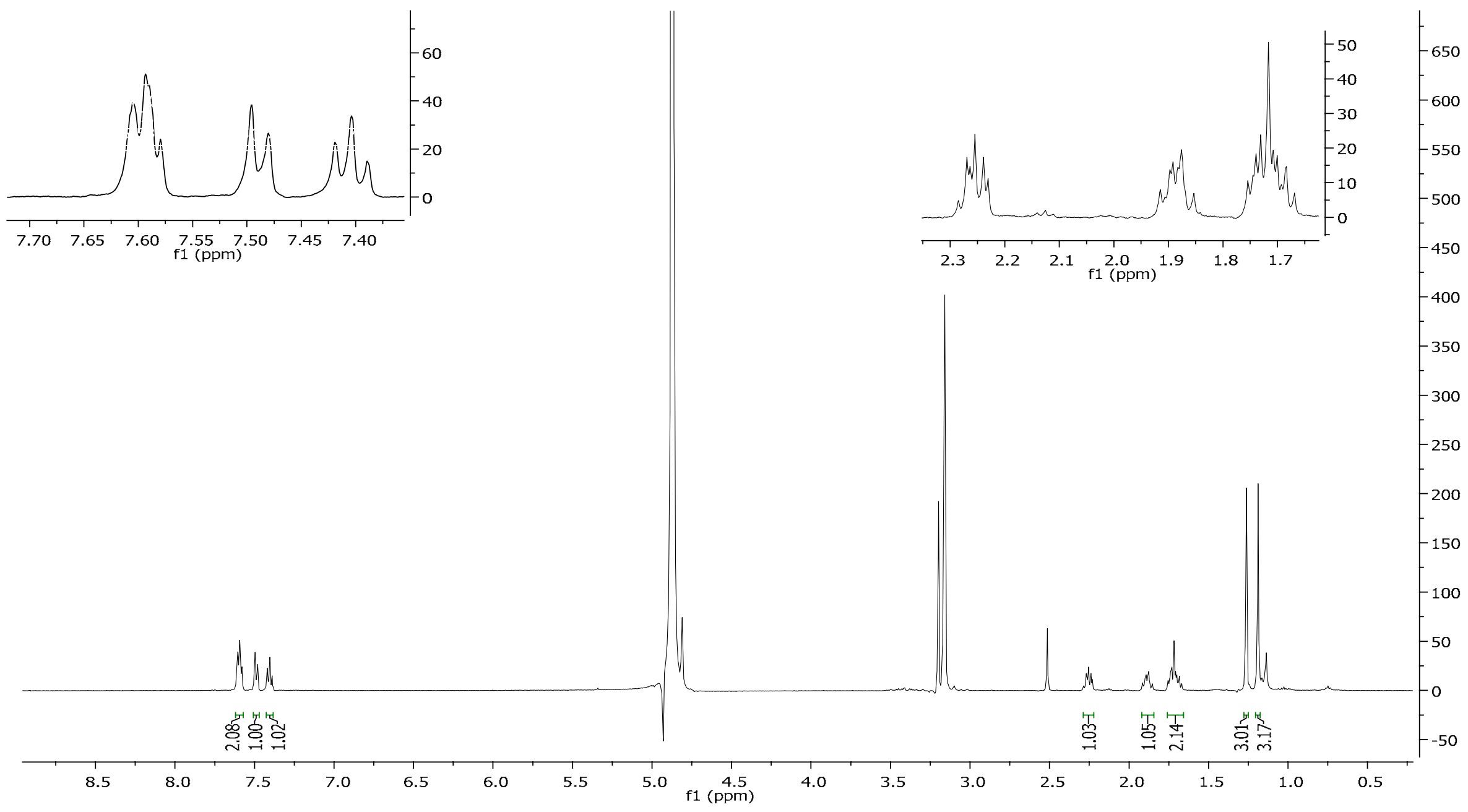

Figura A7. Espectro de RMN de ${ }^{1} \mathrm{H}$ do metabólito $\mathbf{M 1}\left(500 \mathrm{MHz}, \mathrm{CD}_{3} \mathrm{OD}\right)$ 


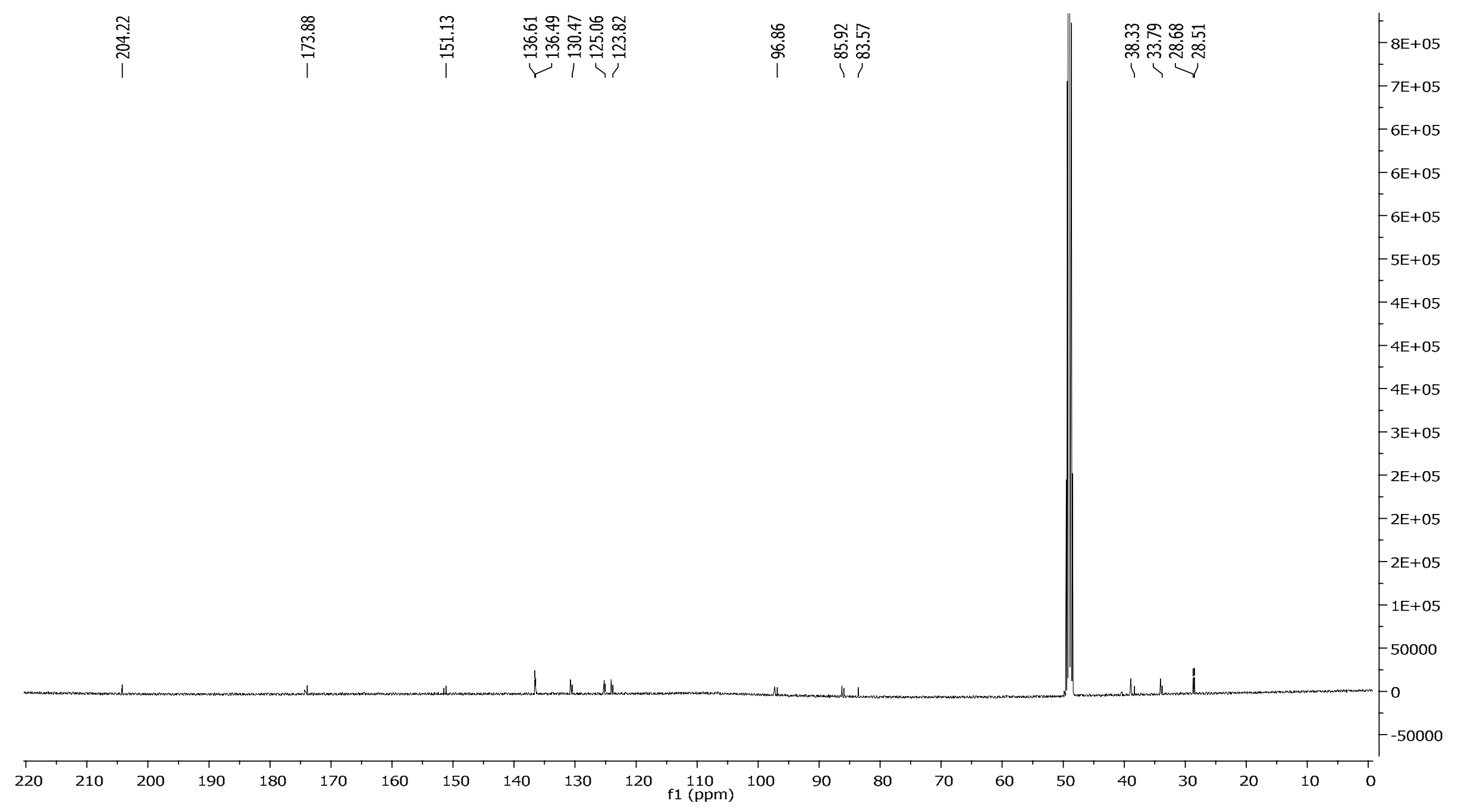

Figura A8. Espectro de RMN de ${ }^{13} \mathrm{C}$ do metabólito $\mathbf{M 1}\left(125 \mathrm{MHz}, \mathrm{CD}_{3} \mathrm{OD}\right)$ 


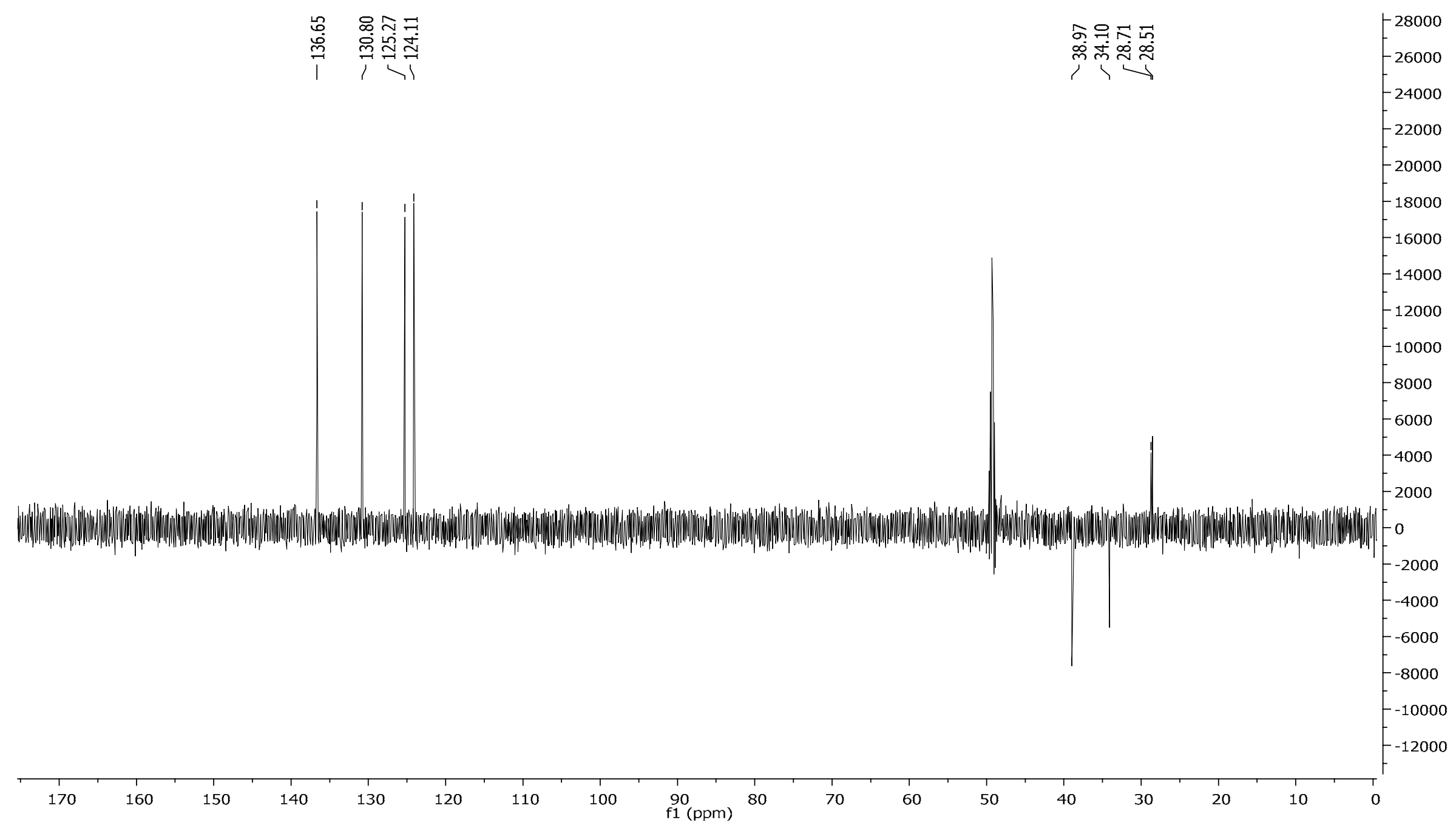

Figura A9. Espectro de DEPT do metabólito M1 (125 MHz, $\left.\mathrm{CD}_{3} \mathrm{OD}\right)$ 


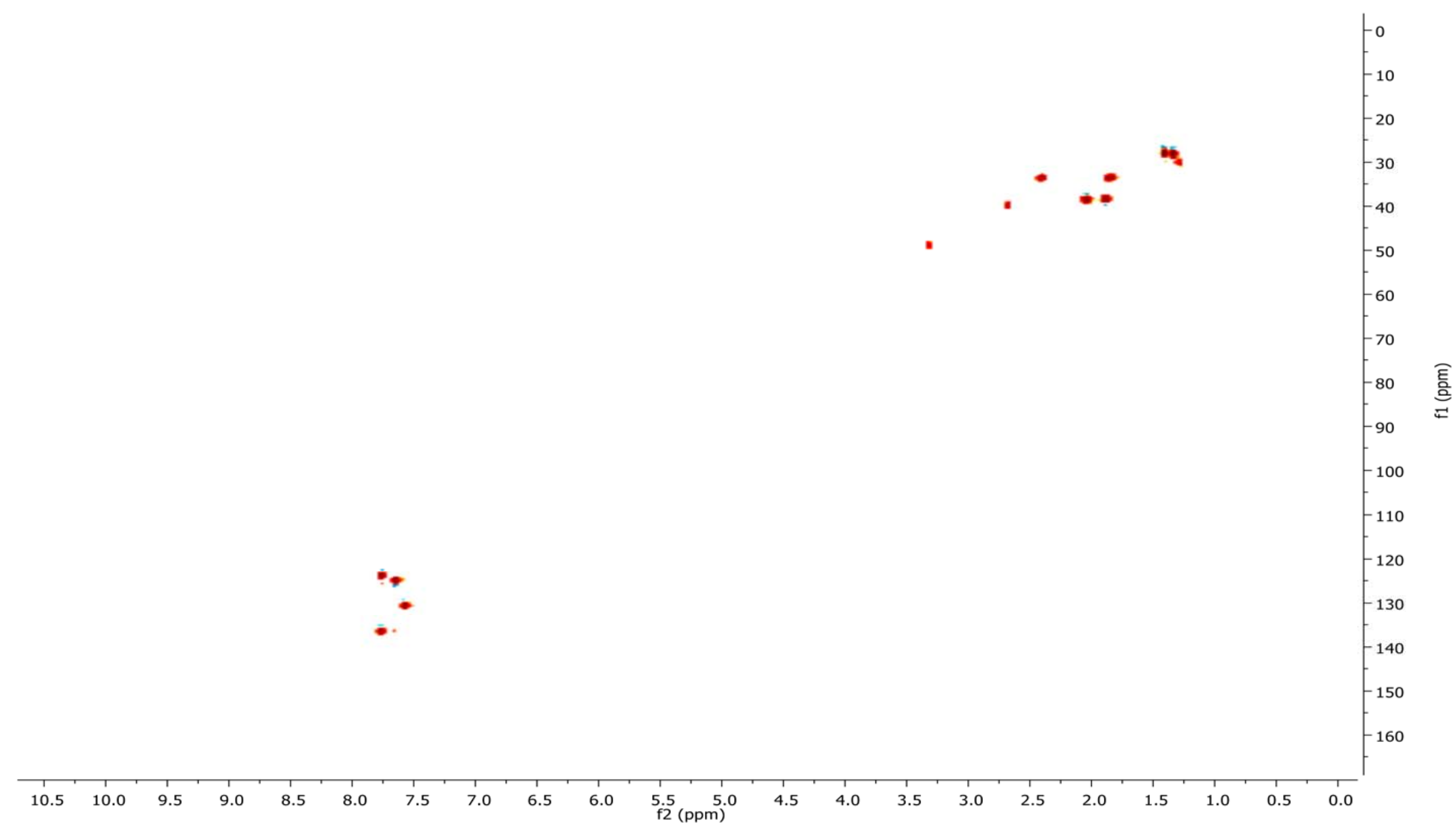

Figura A10. Mapa de contorno de HMQC do metabólito M1 (500 MHz, $\mathrm{CD}_{3} \mathrm{OD}$ ) 


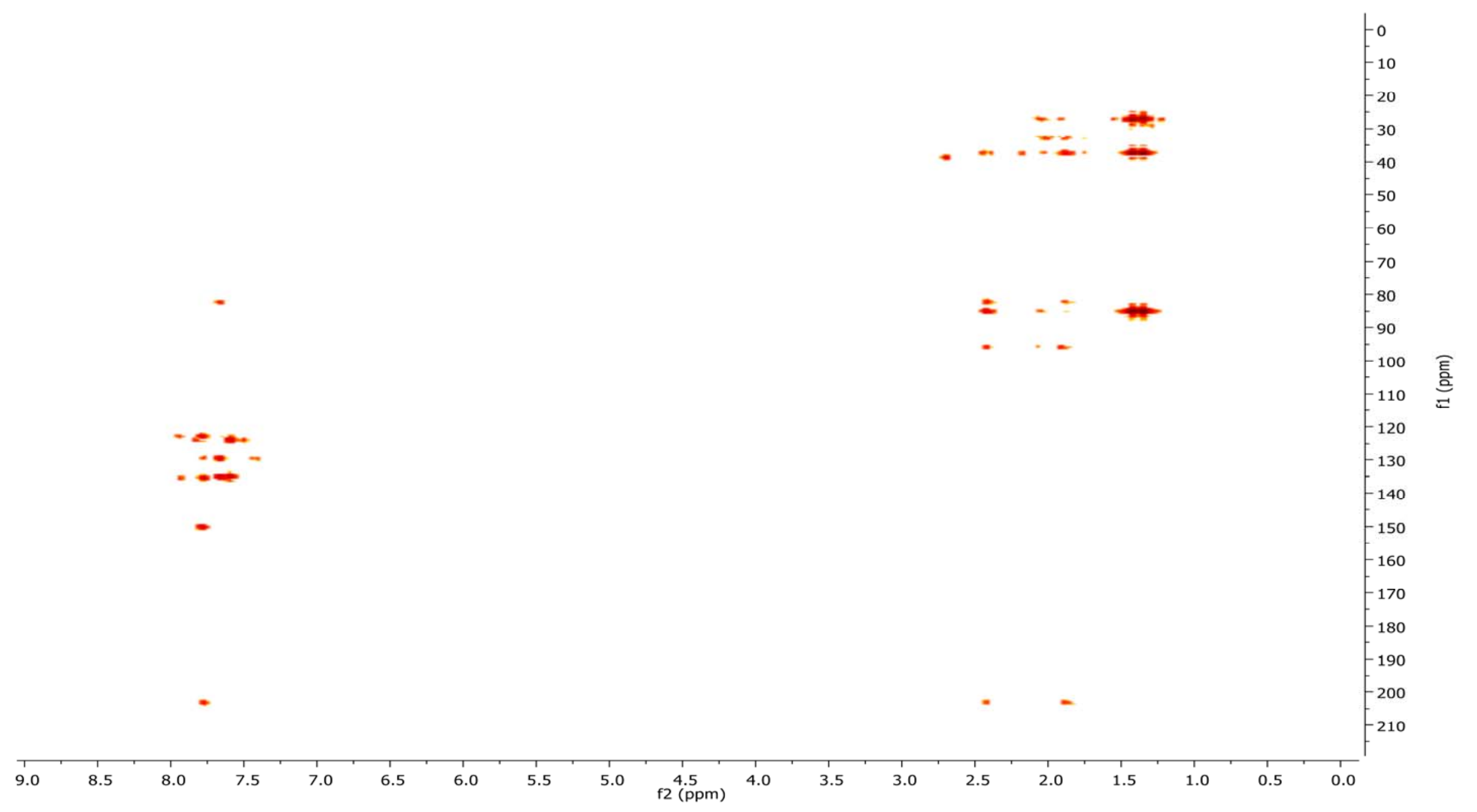

Figura A11. Mapa de contorno de HMBC do metabólito M1 (500 MHz, $\left.\mathrm{CD}_{3} \mathrm{OD}\right)$ 


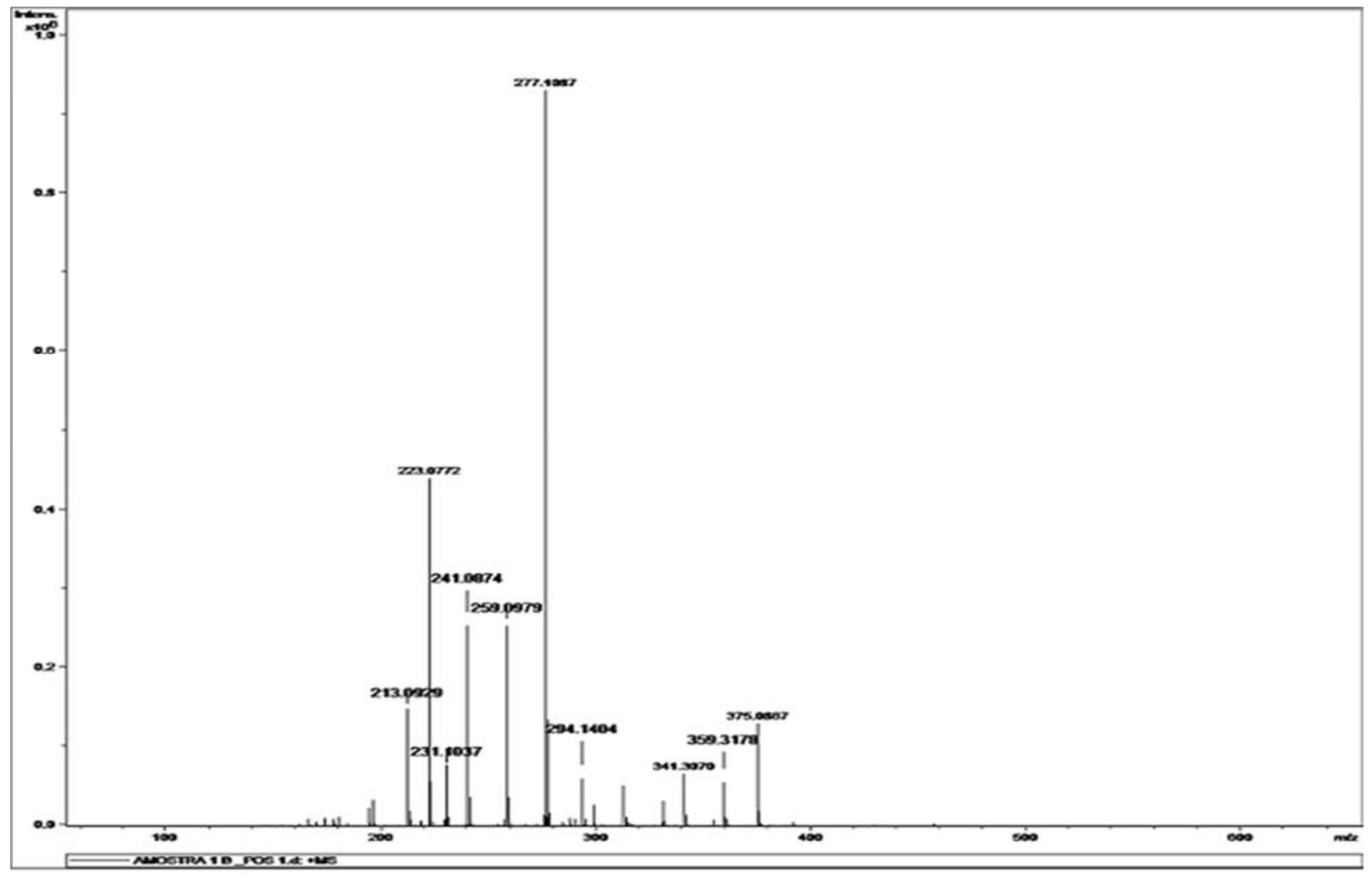

Figura A12. Espectro de massas de alta resolução no modo positivo do metabólito M1 (ESI-TOF; $m / z$ 277.1057 [M+H] $]^{+}$)

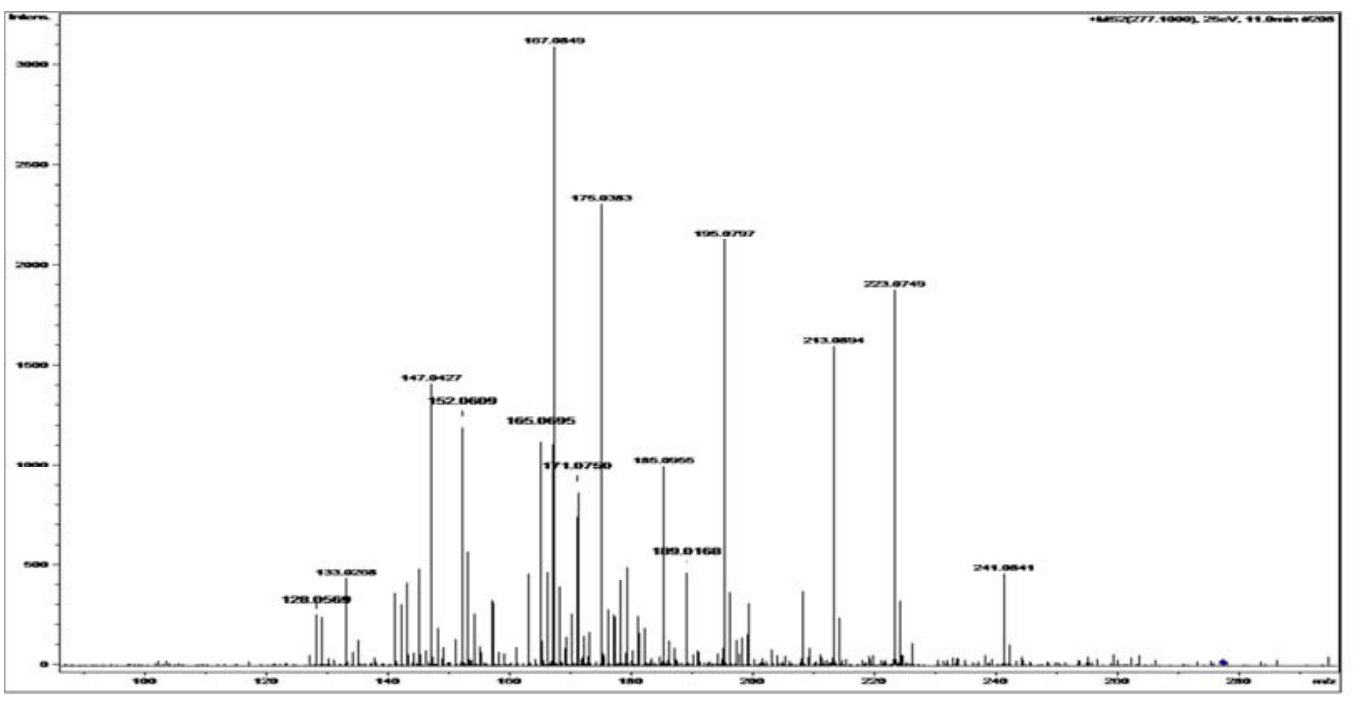

Figura A13. Espectro de EM/EM no modo positivo do metabólito M1 (ESI$\mathrm{MS} / \mathrm{MS}, 25 \mathrm{eV})$ 


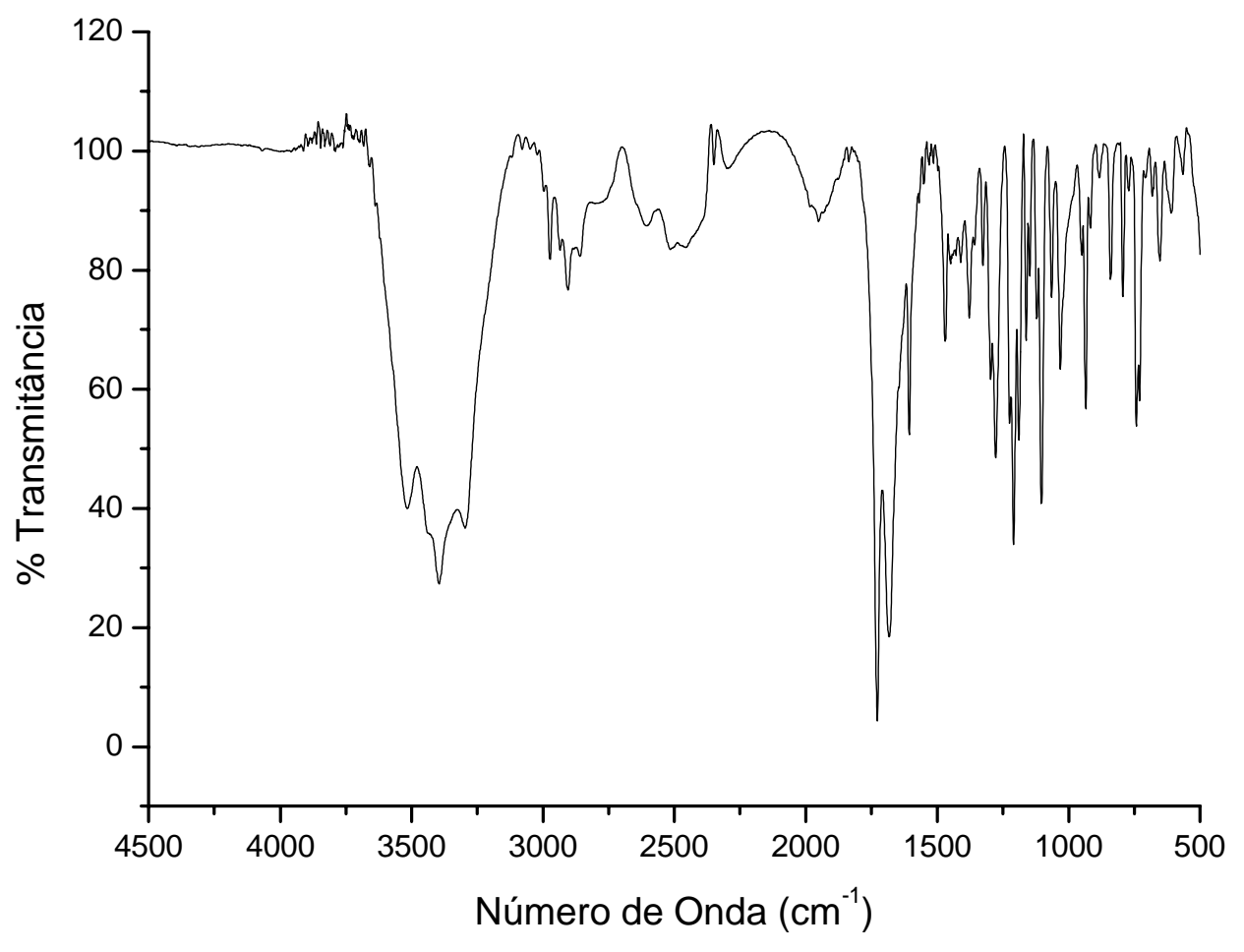

Figura A14. Espectro de infravermelho do metabólito M1 

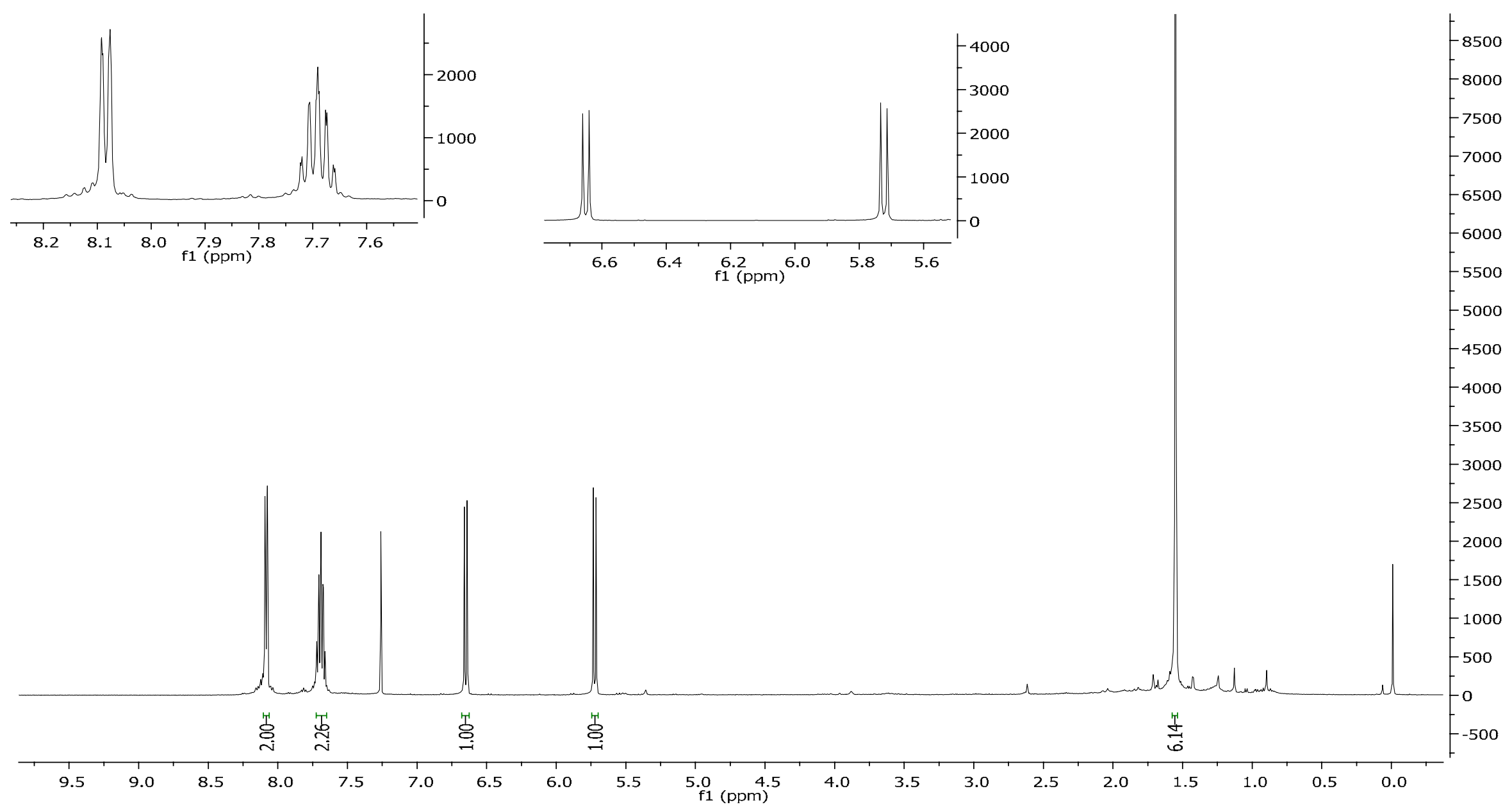

Figura A15. Espectro de RMN de ${ }^{1} \mathrm{H}$ do metabólito $\mathbf{M 2}\left(500 \mathrm{MHz}, \mathrm{CDCl}_{3}\right)$ 


\section{Apêndices}

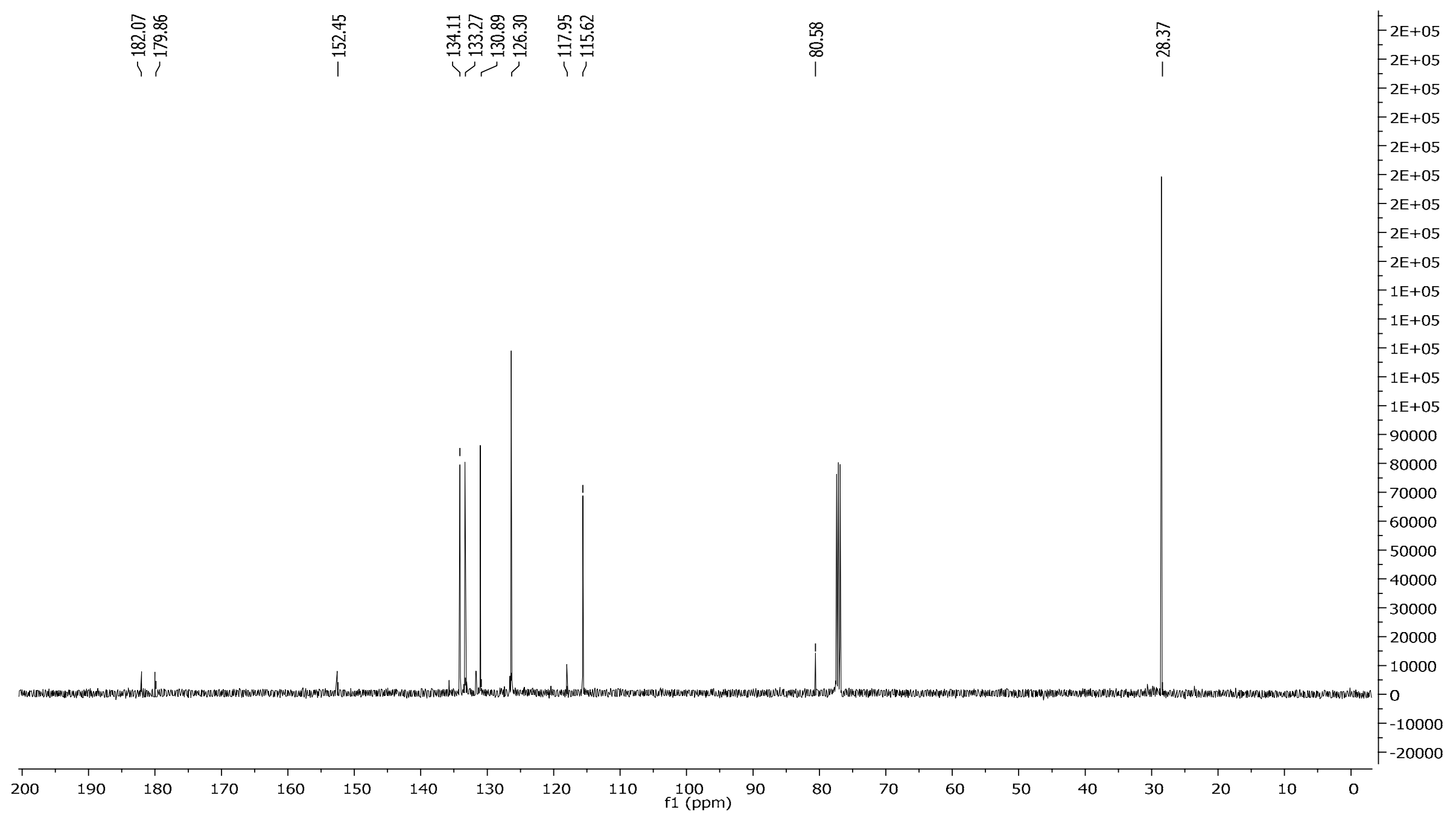

Figura A16. Espectro de $\mathrm{RMN}$ de ${ }^{13} \mathrm{C}$ do metabólito $\mathbf{M 2}\left(125 \mathrm{MHz}, \mathrm{CDCl}_{3}\right)$ 
Apêndices

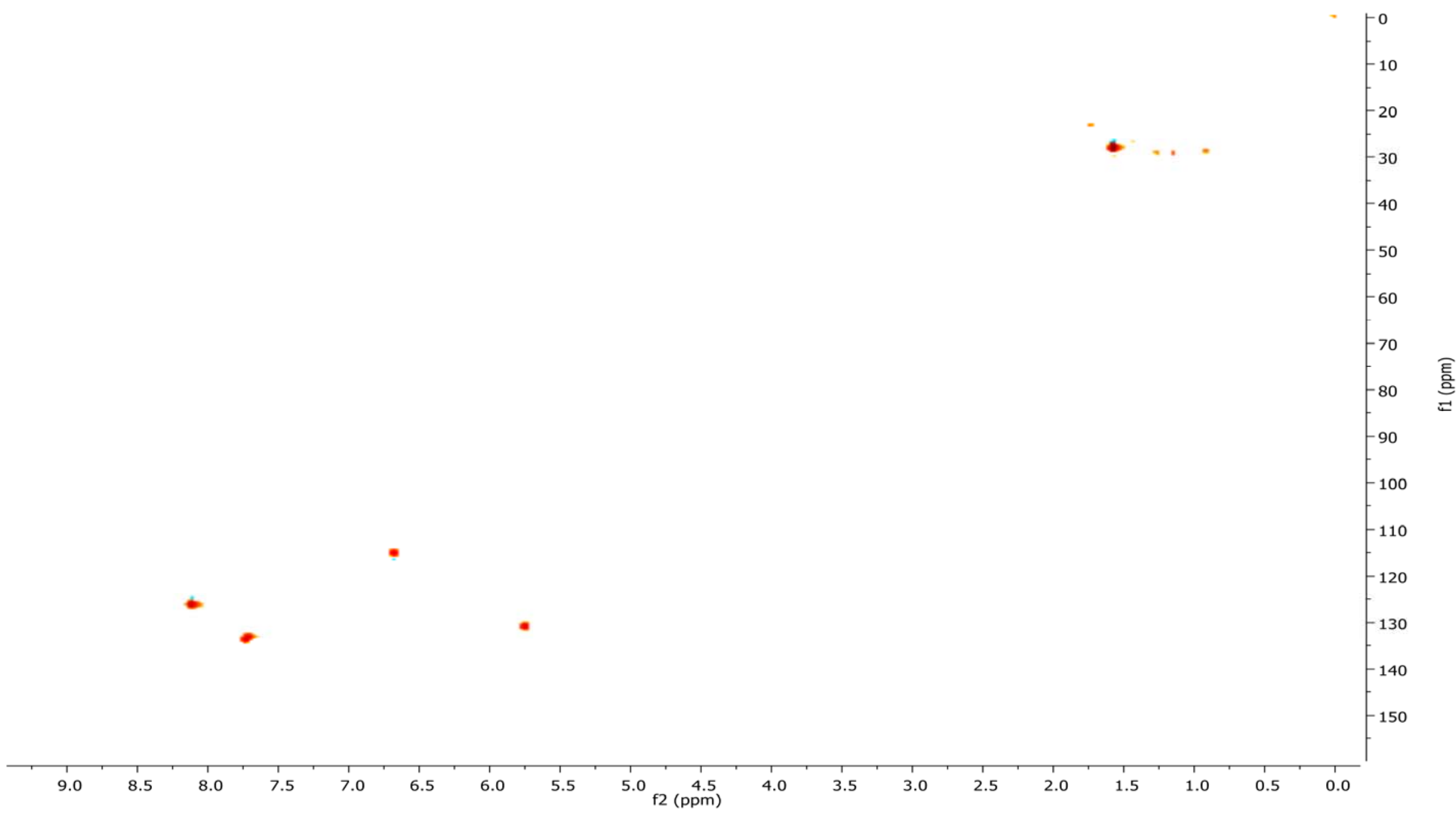

Figura A17. Mapa de contorno de HMQC do metabólito M2 (500 MHz, $\mathrm{CDCl}_{3}$ ) 


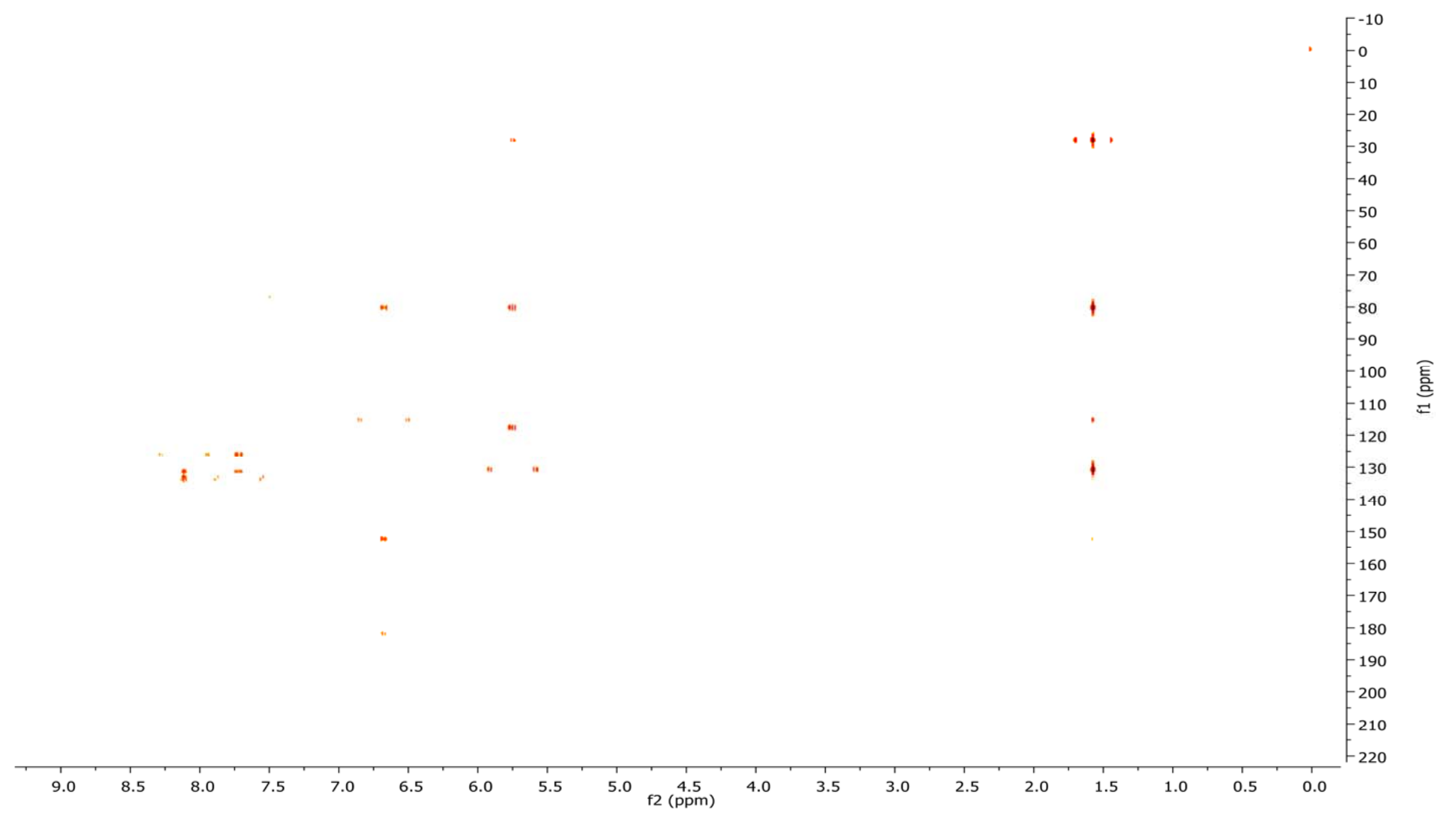

Figura A18. Mapa de contorno de $\mathrm{HMBC}$ do metabólito $\mathbf{M} 2\left(500 \mathrm{MHz}, \mathrm{CDCl}_{3}\right)$ 


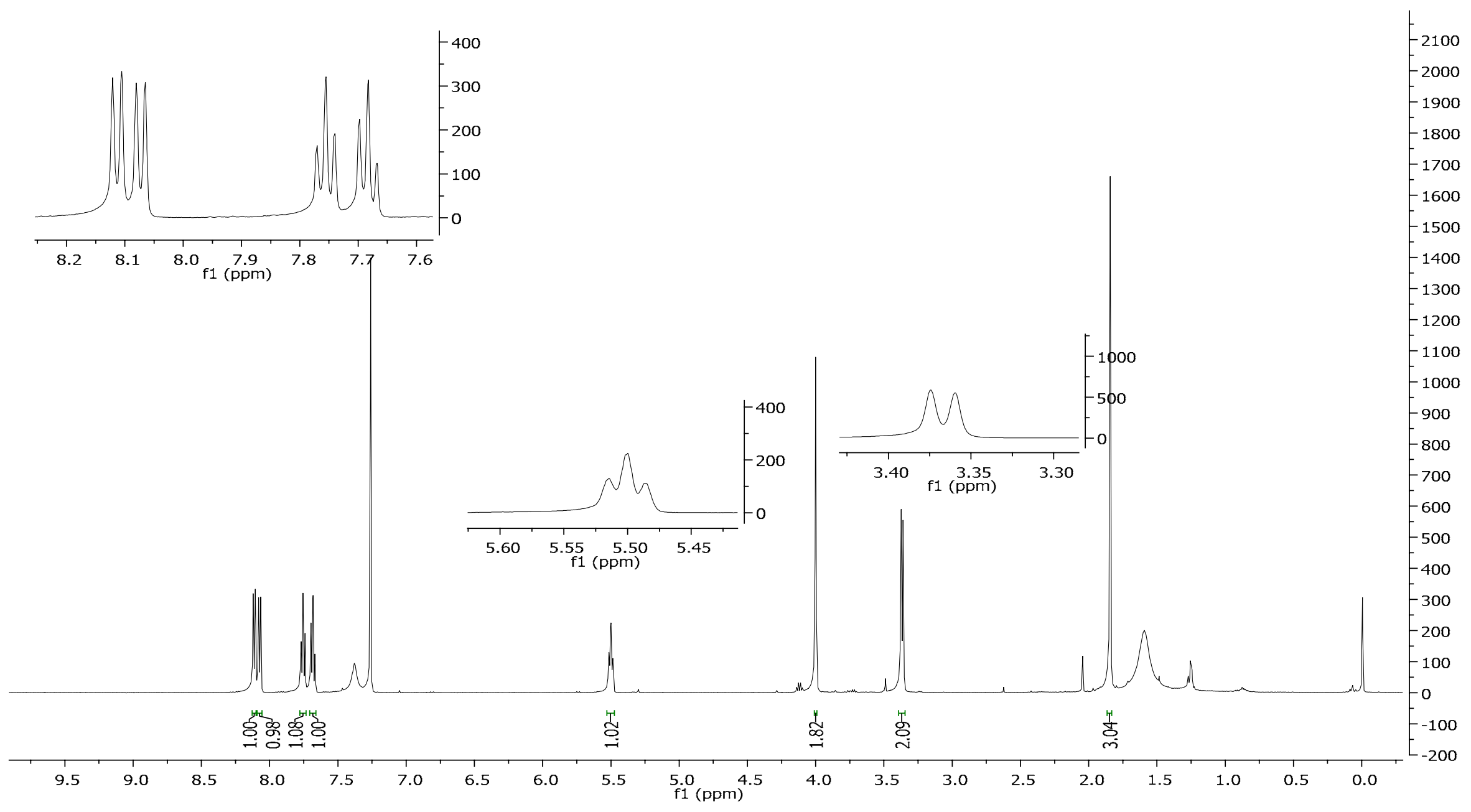

Figura A19. Espectro de $\mathrm{RMN}$ de ${ }^{1} \mathrm{H}$ do metabólito $\mathbf{M 3}\left(500 \mathrm{MHz}, \mathrm{CDCl}_{3}\right)$ 


\section{Apêndices}

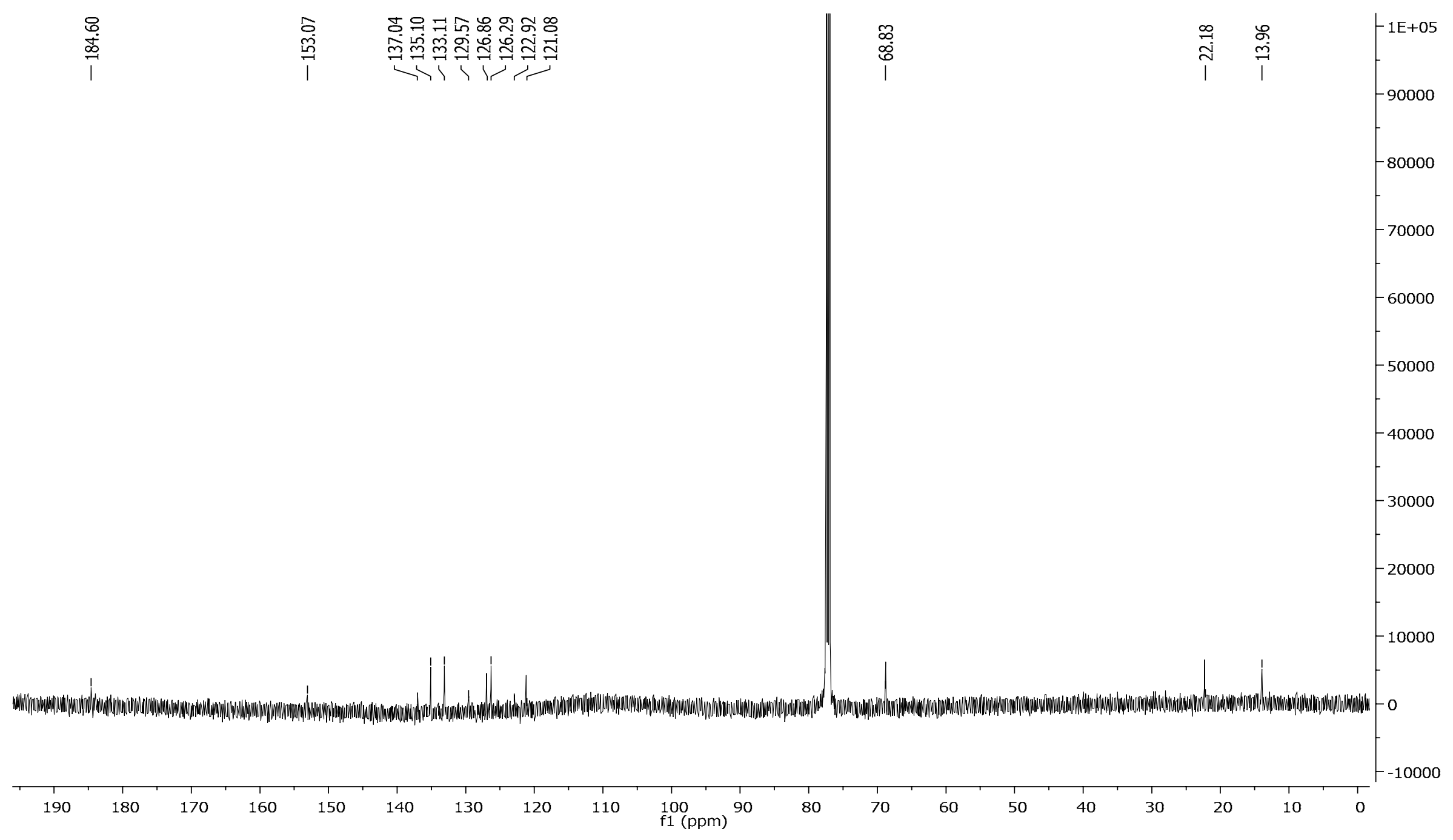

Figura A20. Espectro de $\mathrm{RMN}$ de ${ }^{13} \mathrm{C}$ do metabólito $\mathbf{M 3}\left(125 \mathrm{MHz}, \mathrm{CDCl}_{3}\right.$ ) 


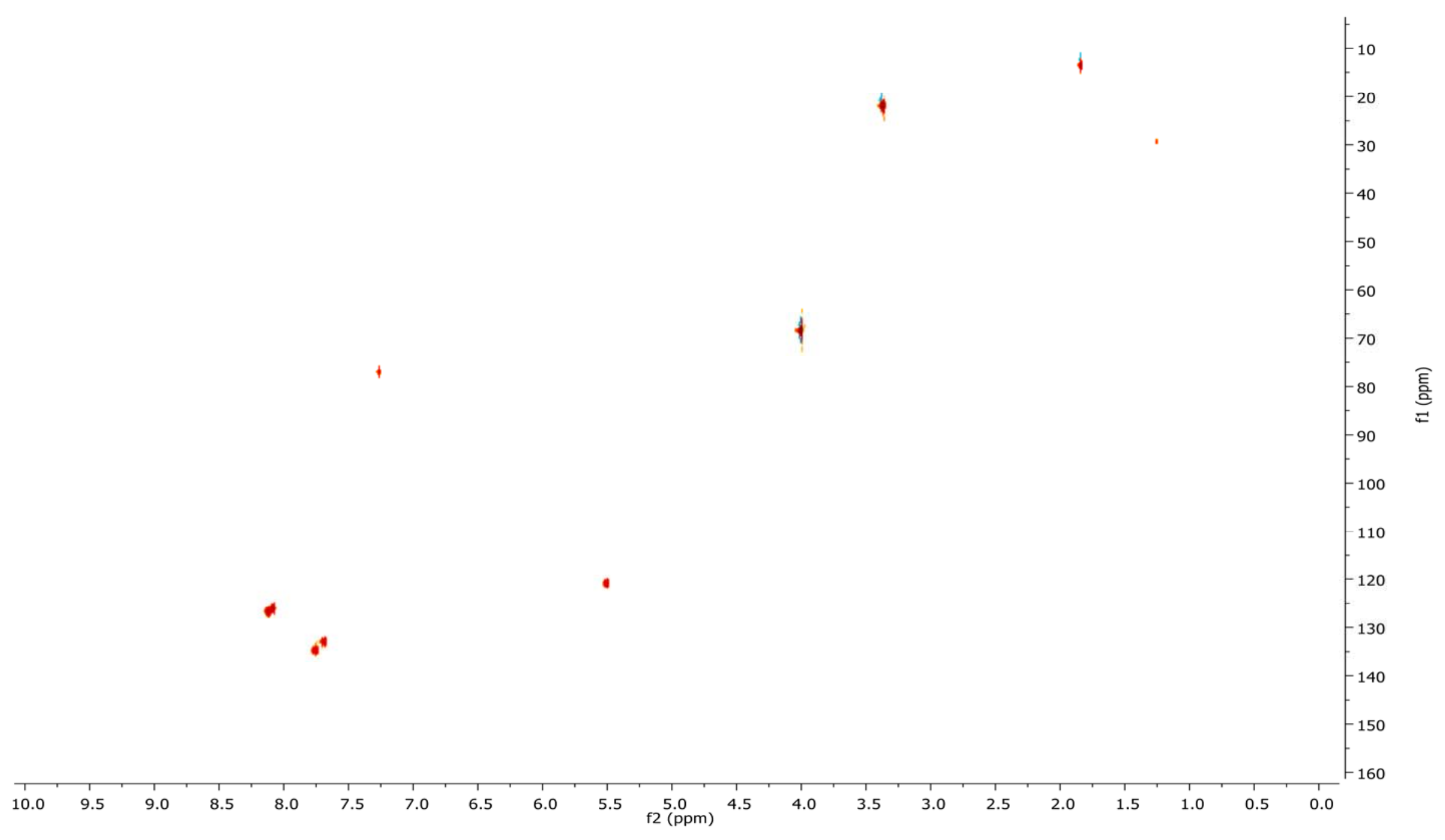

Figura A21. Mapa de contorno de HMQC do metabólito M3 (500 MHz, $\mathrm{CDCl}_{3}$ ) 


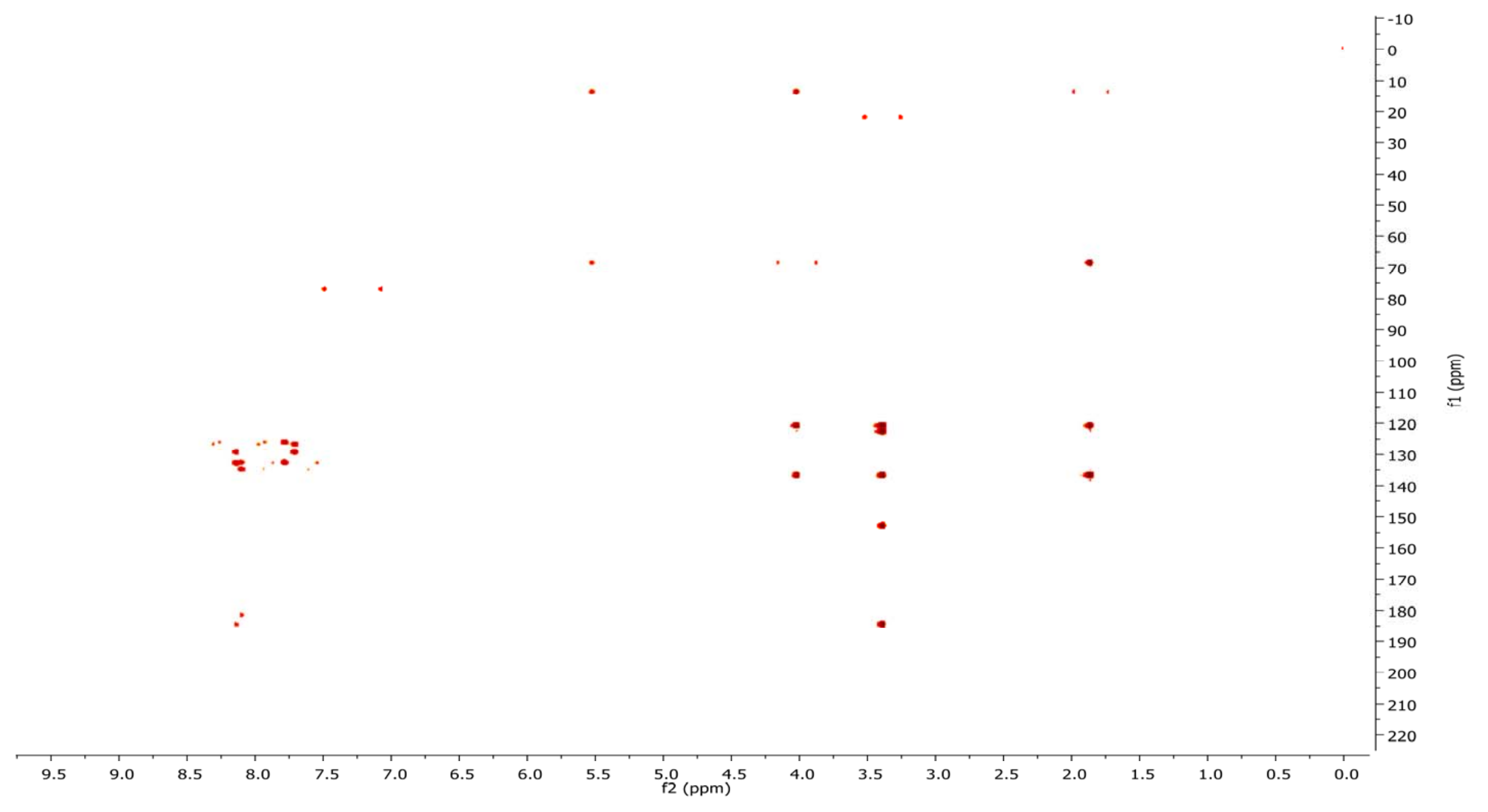

Figura A22. Mapa de contorno de $\mathrm{HMBC}$ do metabólito $\mathbf{M 3}\left(500 \mathrm{MHz}, \mathrm{CDCl}_{3}\right)$ 

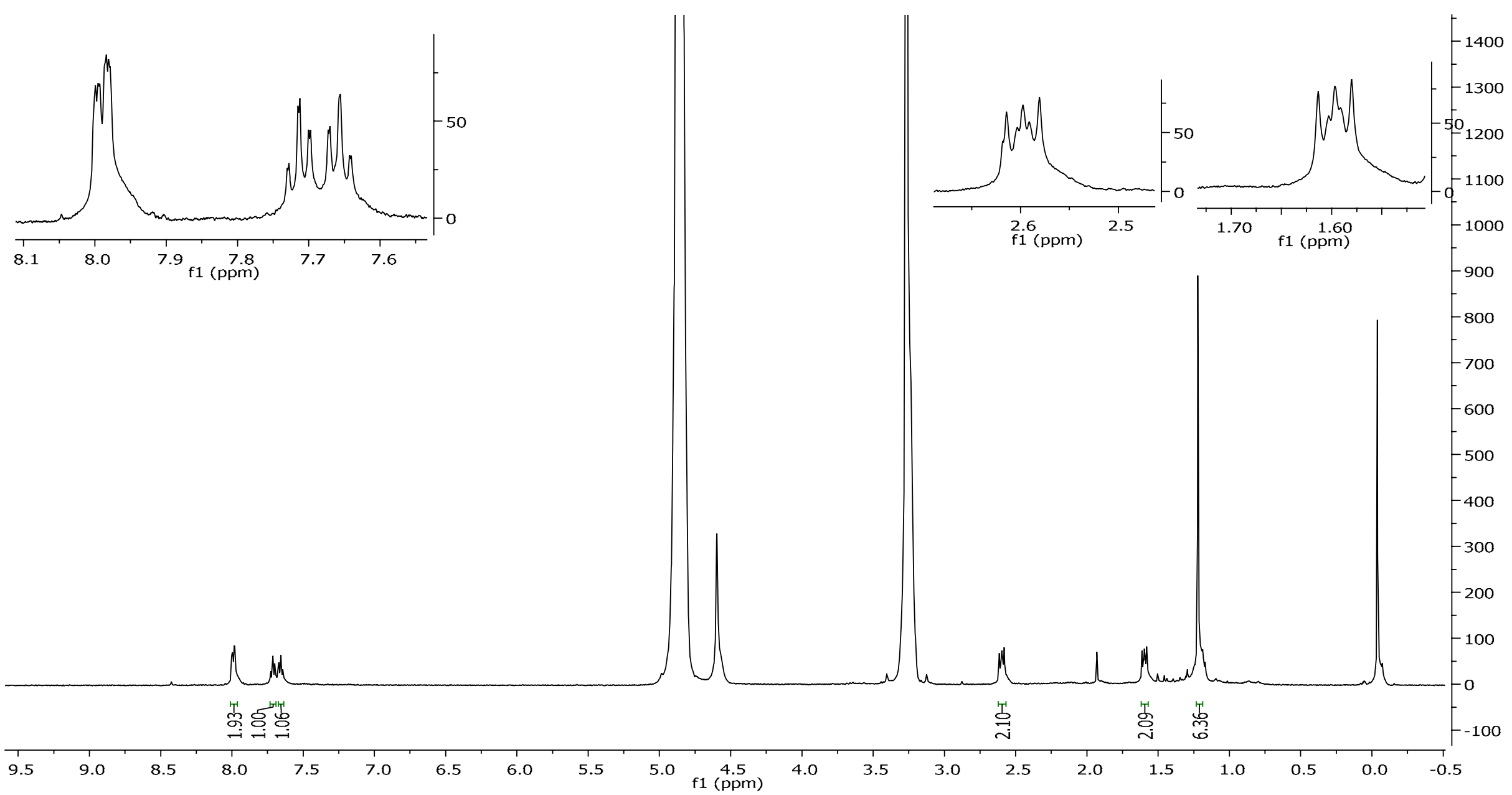

Figura A23. Espectro de $\mathrm{RMN}$ de ${ }^{1} \mathrm{H}$ do metabólito $\mathbf{M} 4\left(500 \mathrm{MHz}, \mathrm{CD}_{3} \mathrm{OD}\right)$ 


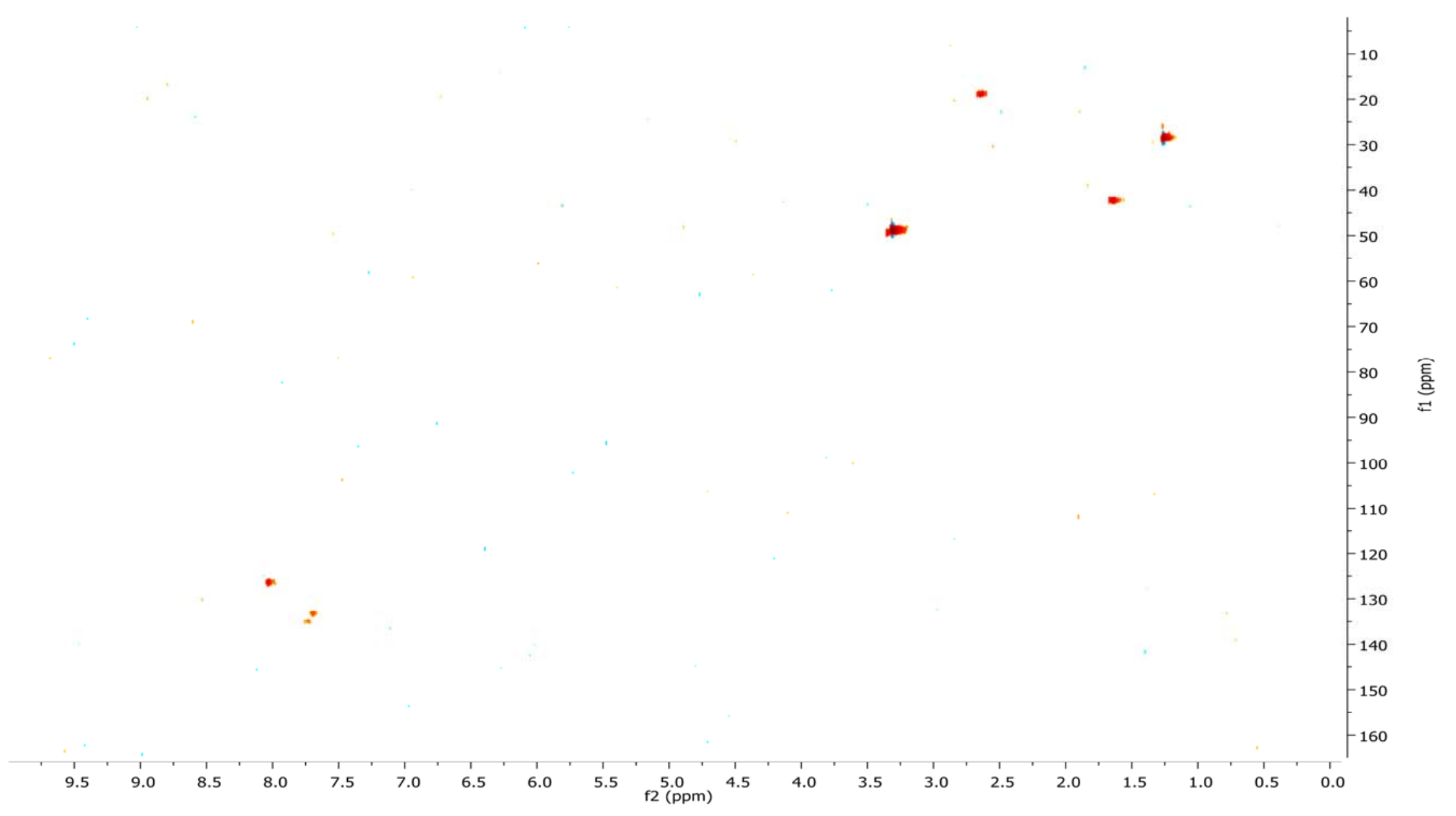

Figura A24. Mapa de contorno de HMQC do metabólito M4 (500 MHz, $\left.\mathrm{CD}_{3} \mathrm{OD}\right)$ 


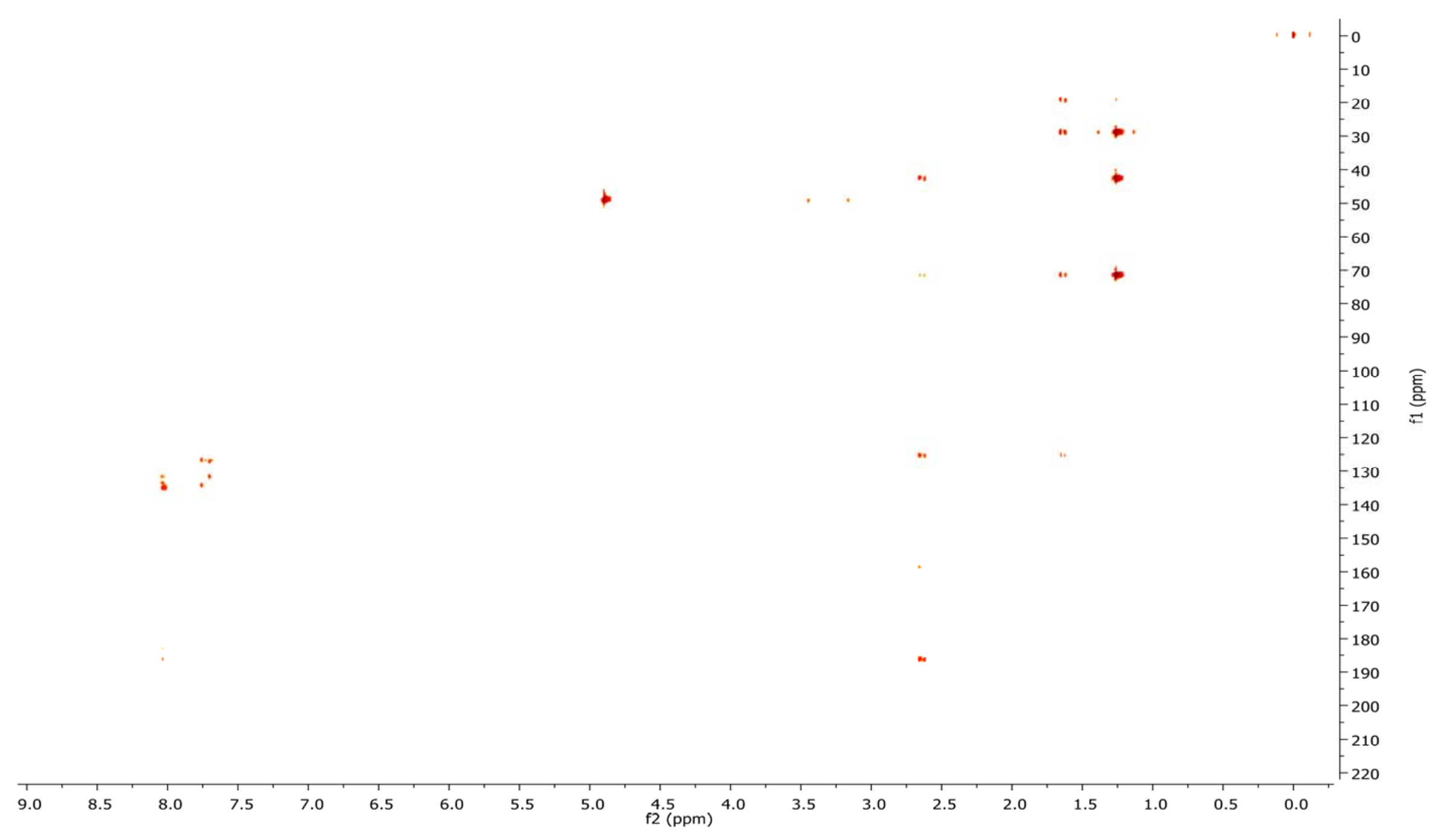

Figura A25. Mapa de contorno de $\mathrm{HMBC}$ do metabólito $\mathbf{M 4}\left(500 \mathrm{MHz}, \mathrm{CD}_{3} \mathrm{OD}\right)$ 

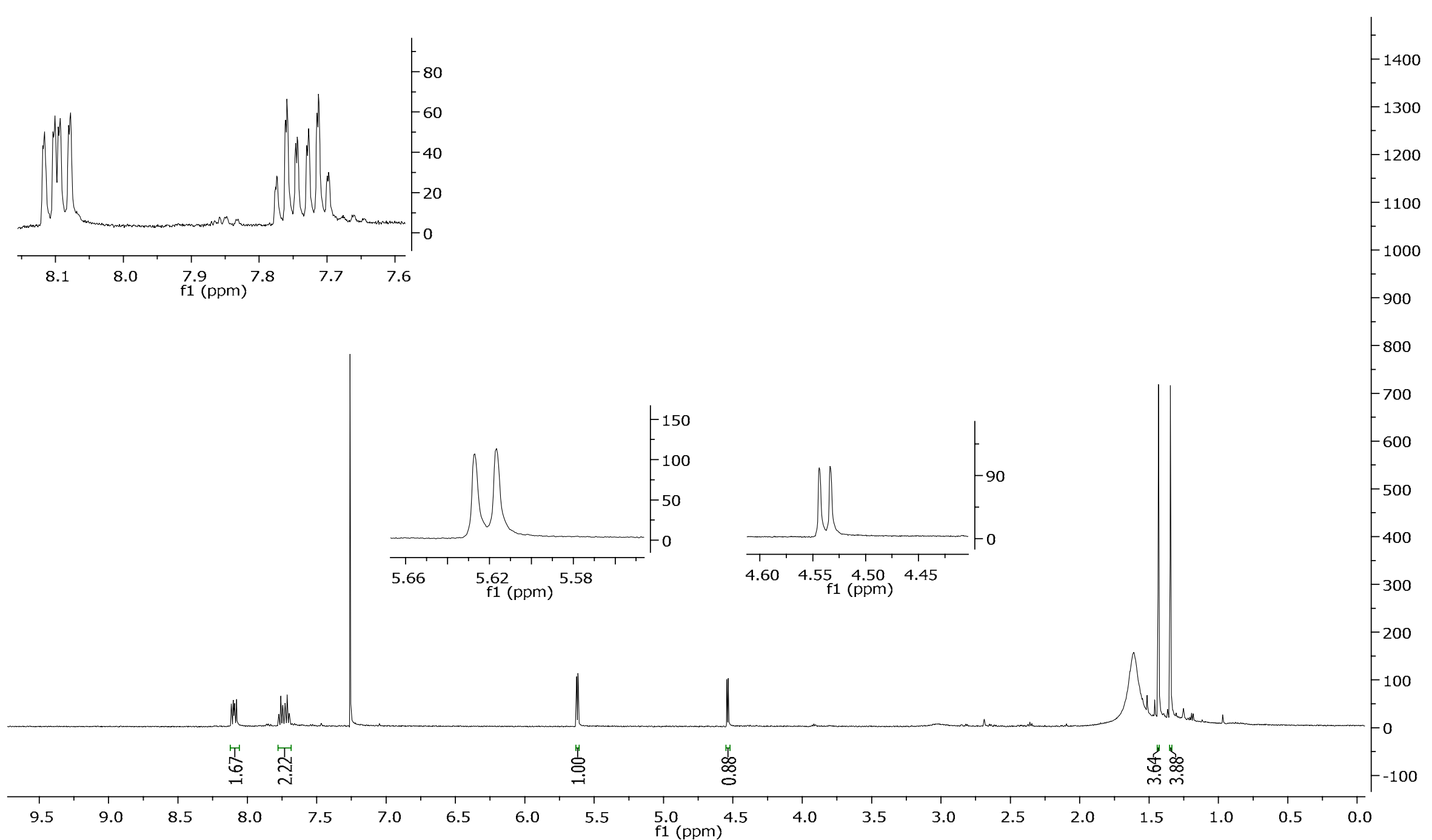

Figura A26. Espectro de RMN de ${ }^{1} \mathrm{H}$ do metabólito $\mathbf{M 5}\left(500 \mathrm{MHz}, \mathrm{CDCl}_{3}\right.$ ) 


\section{Apêndices}

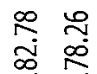

$\stackrel{\infty}{\stackrel{\infty}{\rightarrow}} \stackrel{\infty}{\mid}$

官

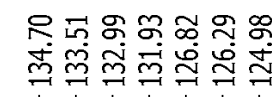

号

พก

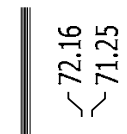

후ㅇㅝㅠ

600

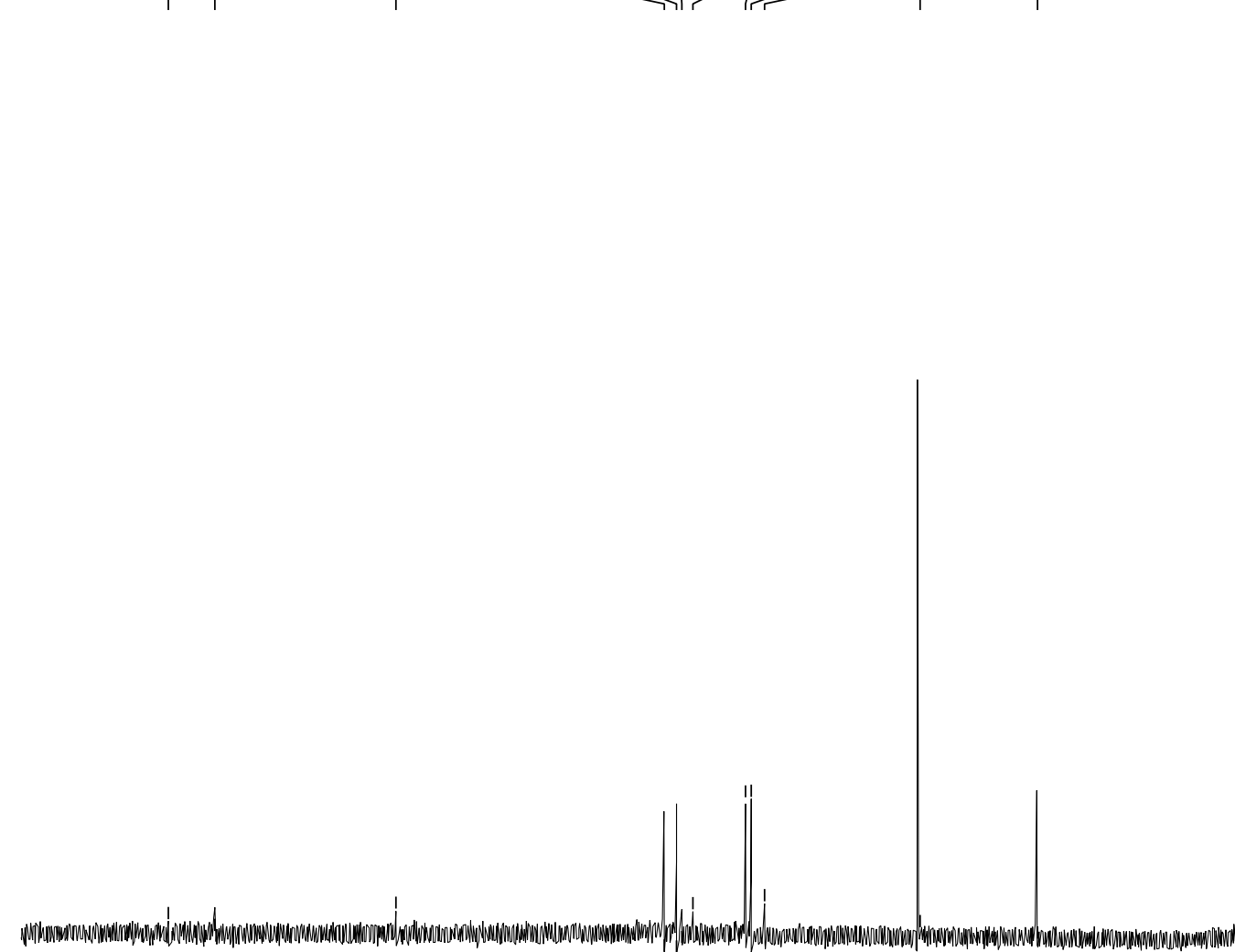

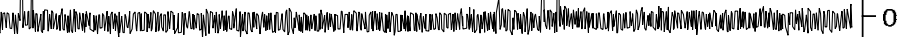

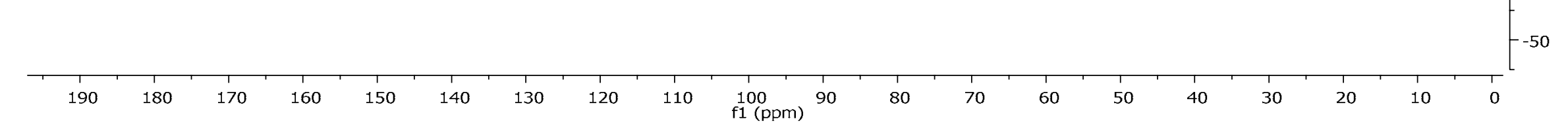

Figura A27. Espectro de RMN de ${ }^{13} \mathrm{C}$ do metabólito $\mathbf{M 5}\left(125 \mathrm{MHz}, \mathrm{CDCl}_{3}\right)$ 


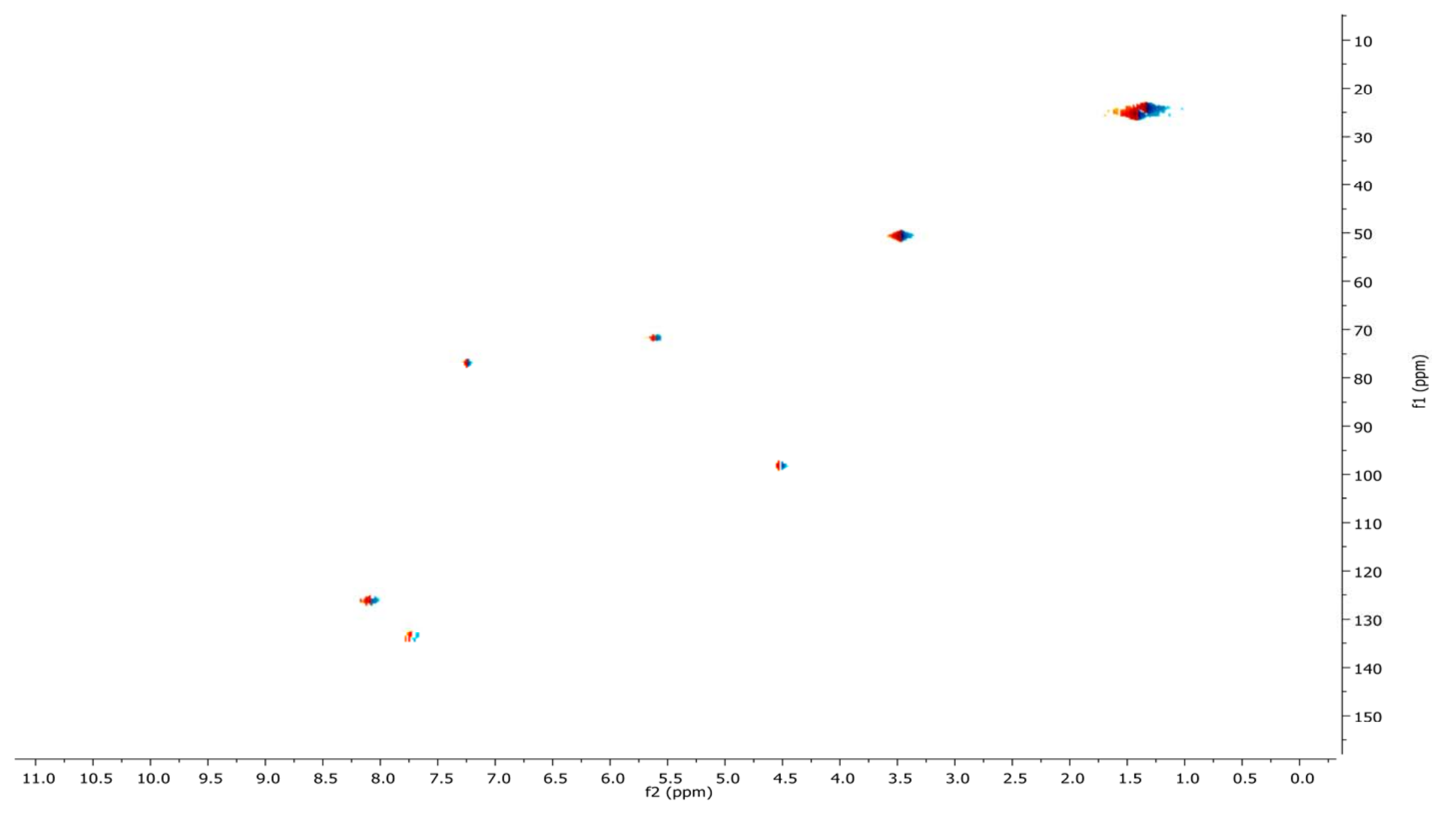

Figura A28. Mapa de contorno de HMQC do metabólito $\mathbf{M 5}\left(500 \mathrm{MHz}, \mathrm{CDCl}_{3}\right)$ 


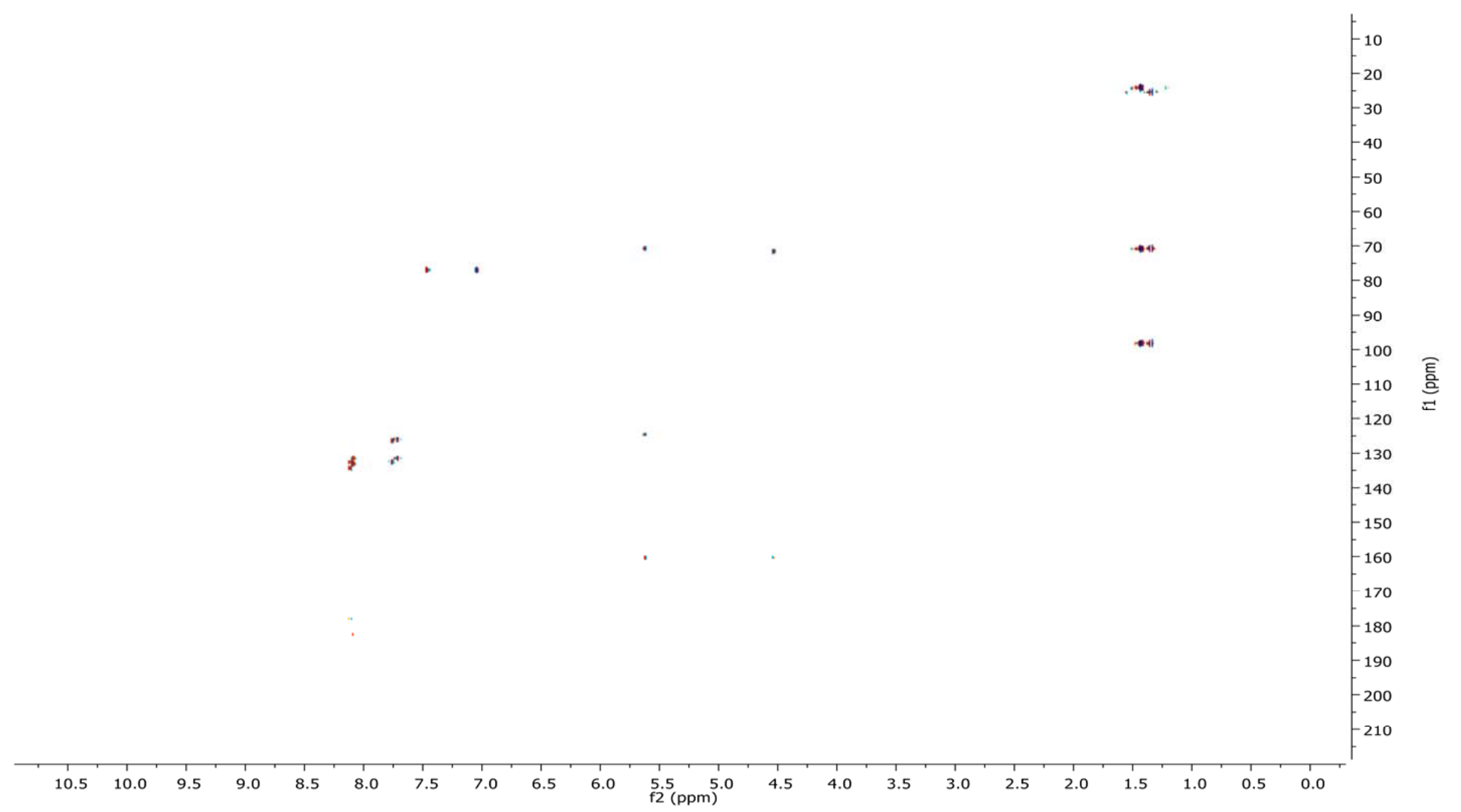

Figura A29. Mapa de contorno de $\mathrm{HMBC}$ do metabólito $\mathbf{M 5}\left(500 \mathrm{MHz}, \mathrm{CDCl}_{3}\right)$ 

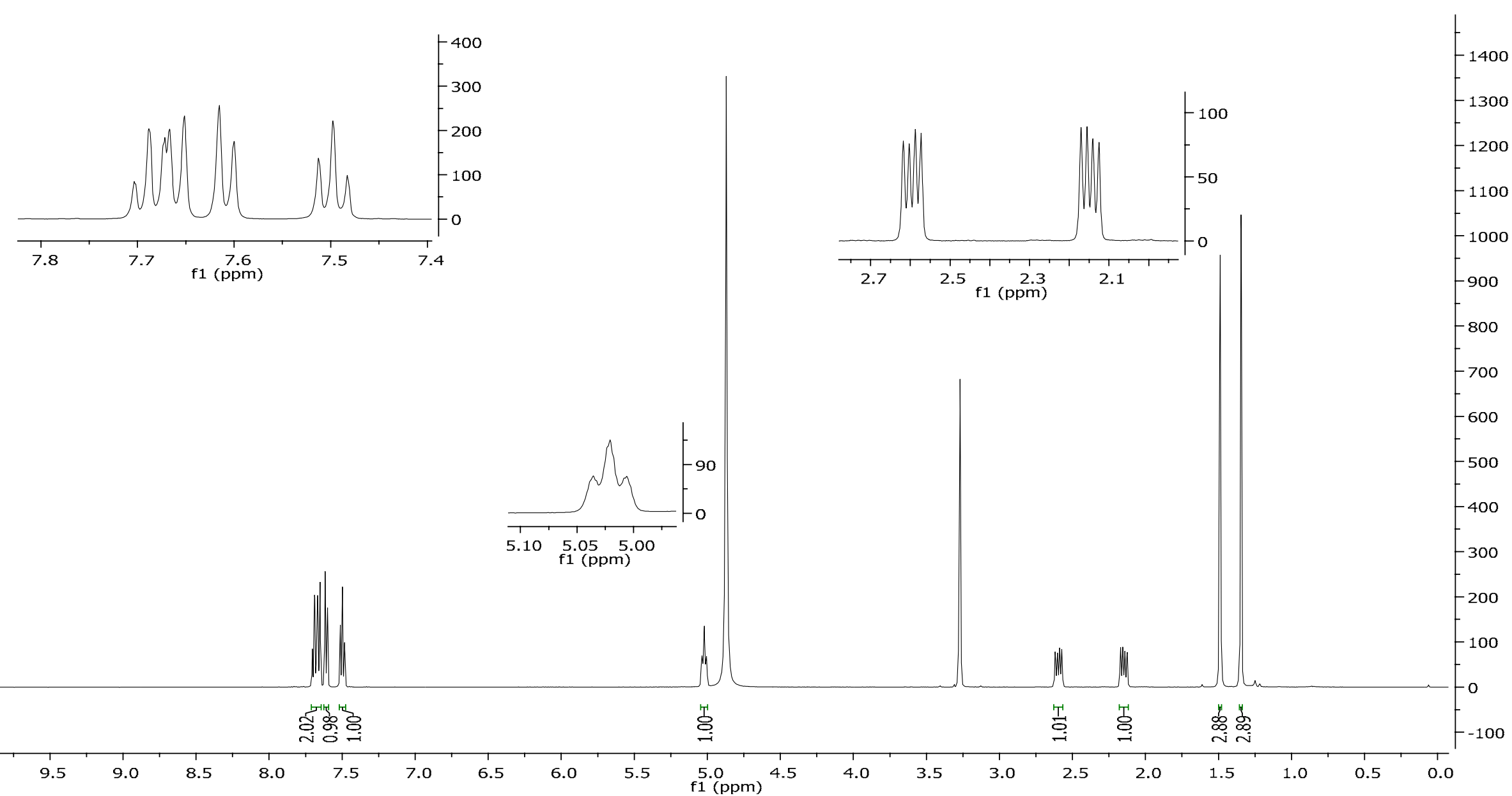

Figura A30. Espectro de RMN de ${ }^{1} \mathrm{H}$ do metabólito M6 (500 MHz, $\mathrm{CD}_{3} \mathrm{OD}$ ) 


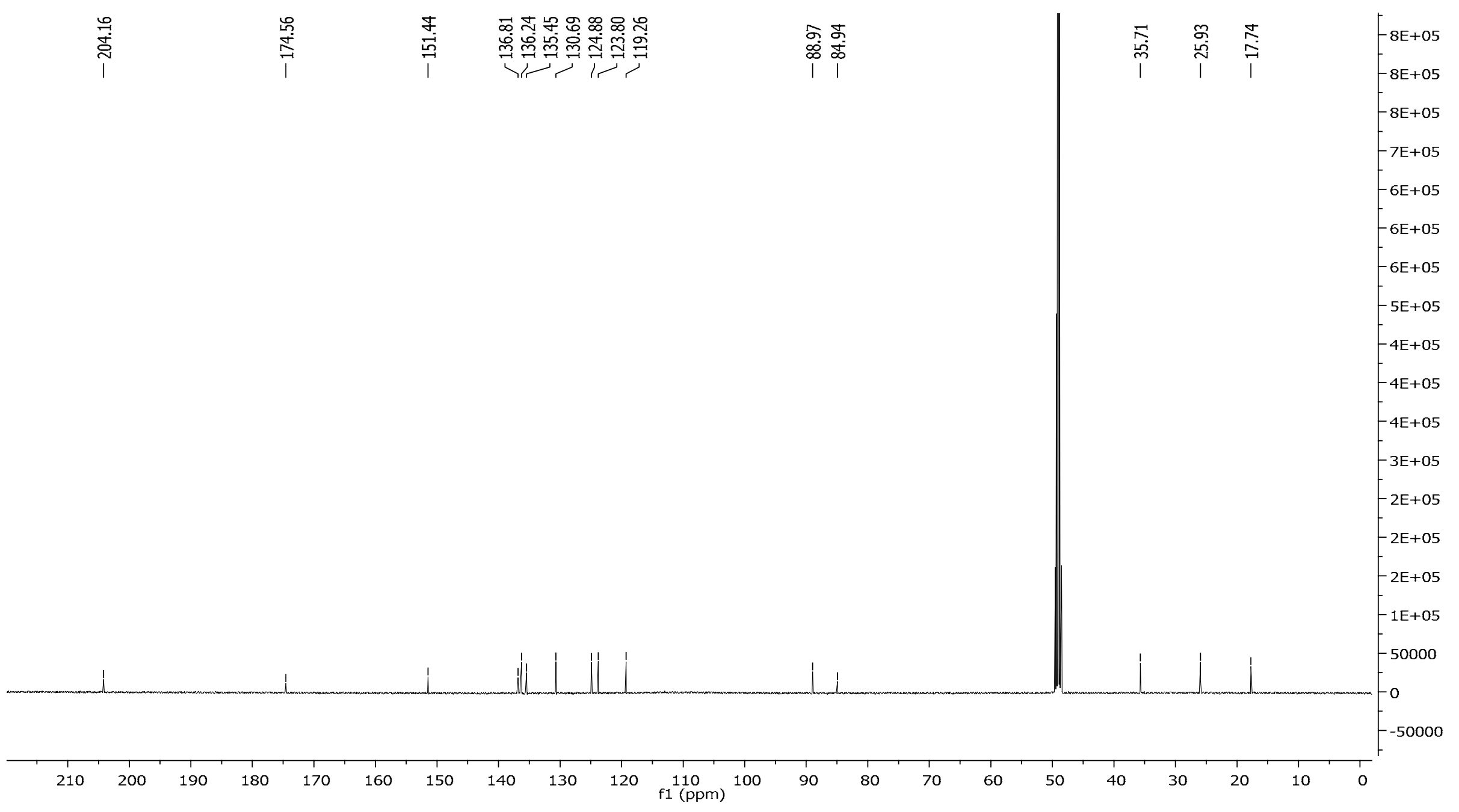

Figura A31. Espectro de $\mathrm{RMN}$ de ${ }^{13} \mathrm{C}$ do metabólito $\mathbf{M 6}$ (125 MHz, $\mathrm{CD}_{3} \mathrm{OD}$ ) 


\section{Apêndices}

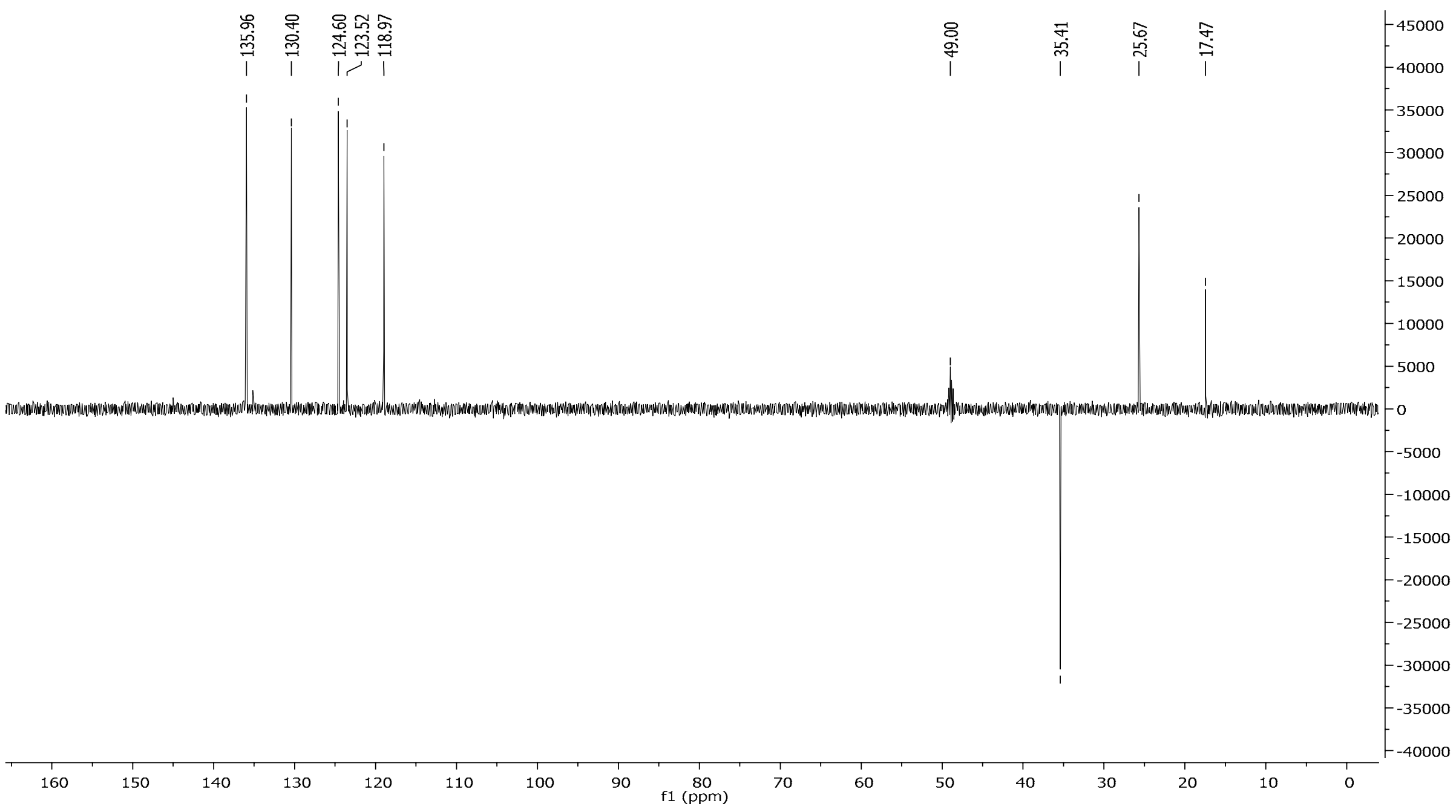

Figura A32. Espectro de DEPT do metabólito M6 (125 MHz, $\left.\mathrm{CD}_{3} \mathrm{OD}\right)$ 


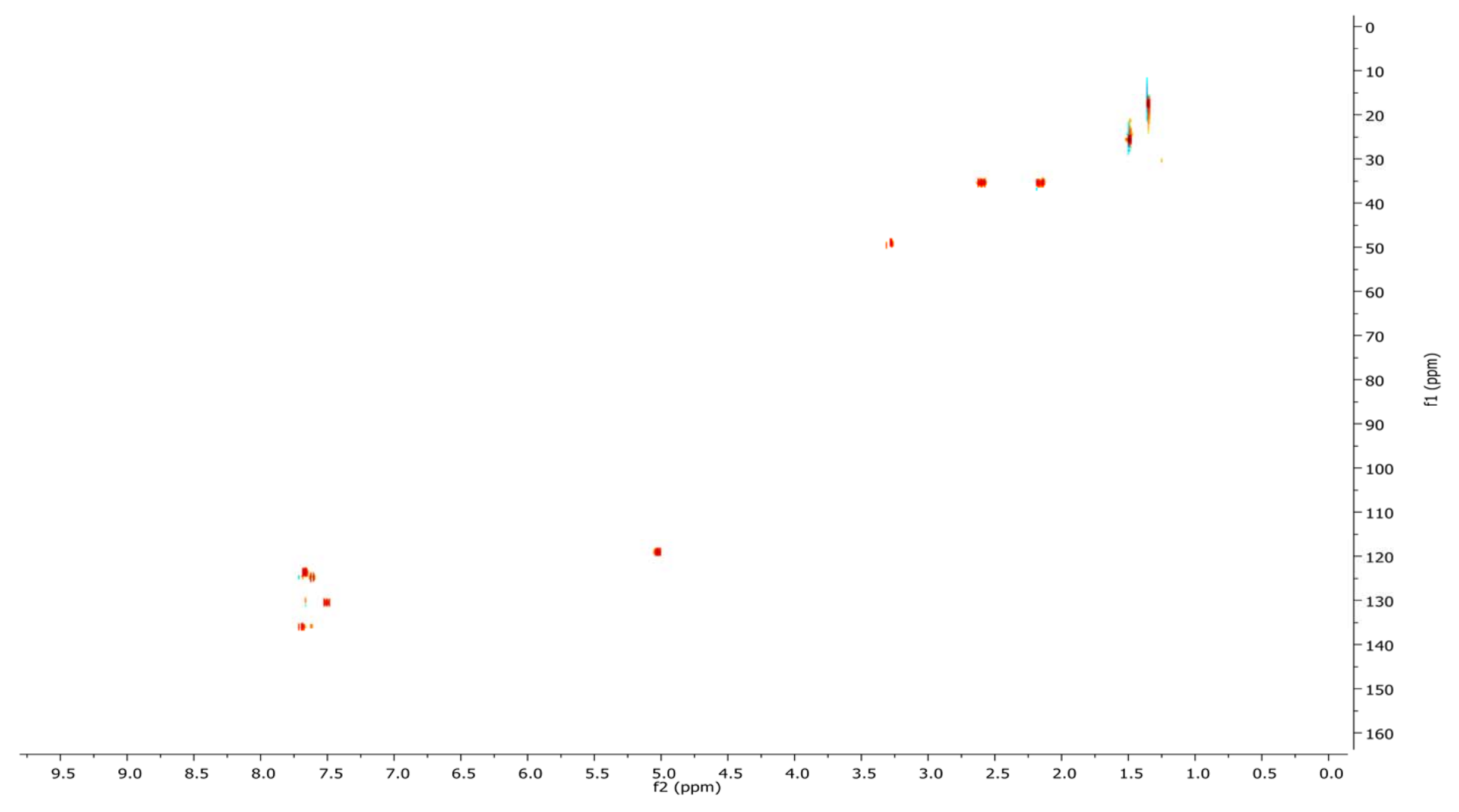

Figura A33. Mapa de contorno de HMQC do metabólito M6 (500 MHz, $\mathrm{CD}_{3} \mathrm{OD}$ ) 


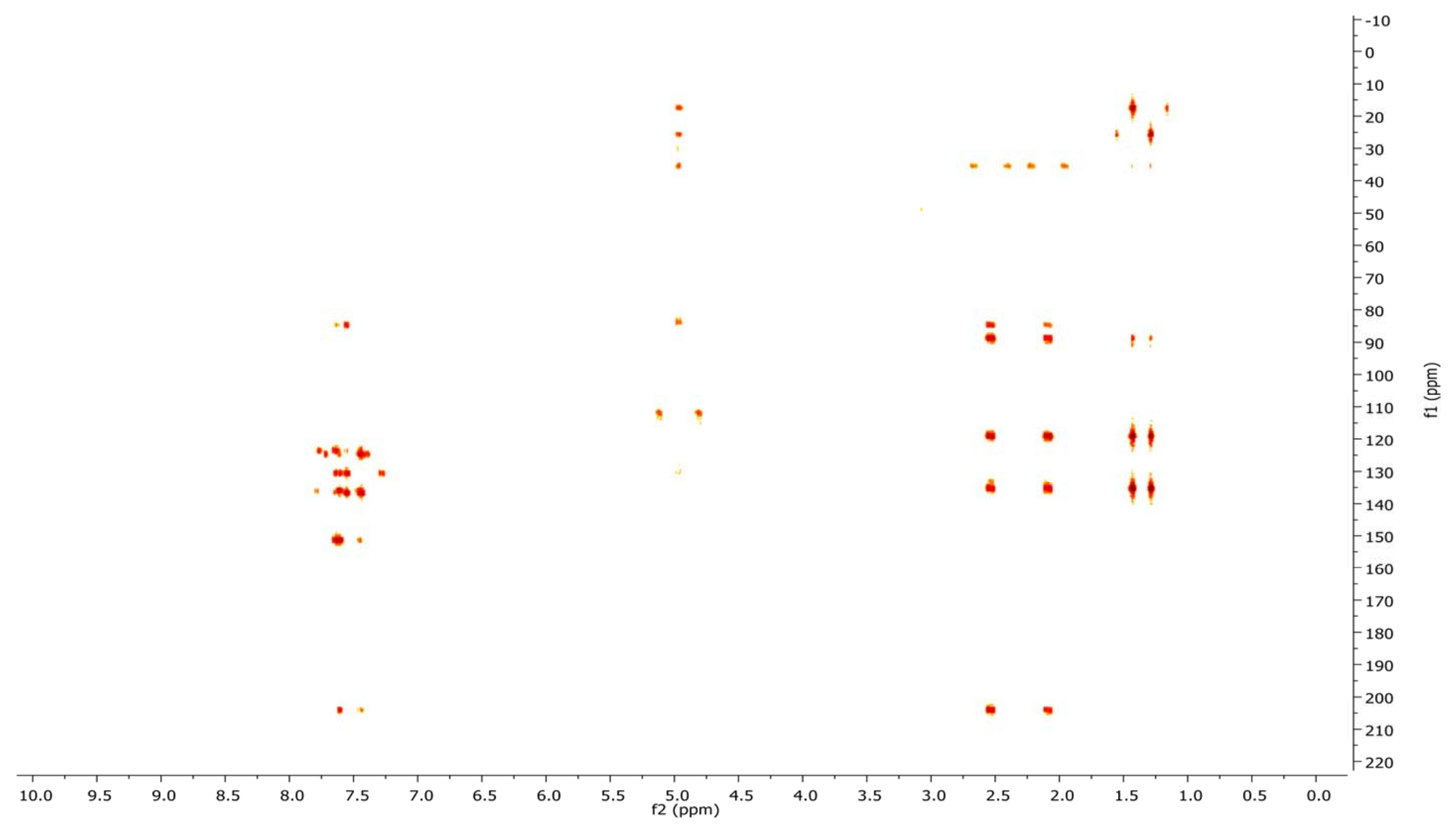

Figura A34. Mapa de contorno de HMBC do metabólito M6 (500 MHz, $\mathrm{CD}_{3} \mathrm{OD}$ ) 


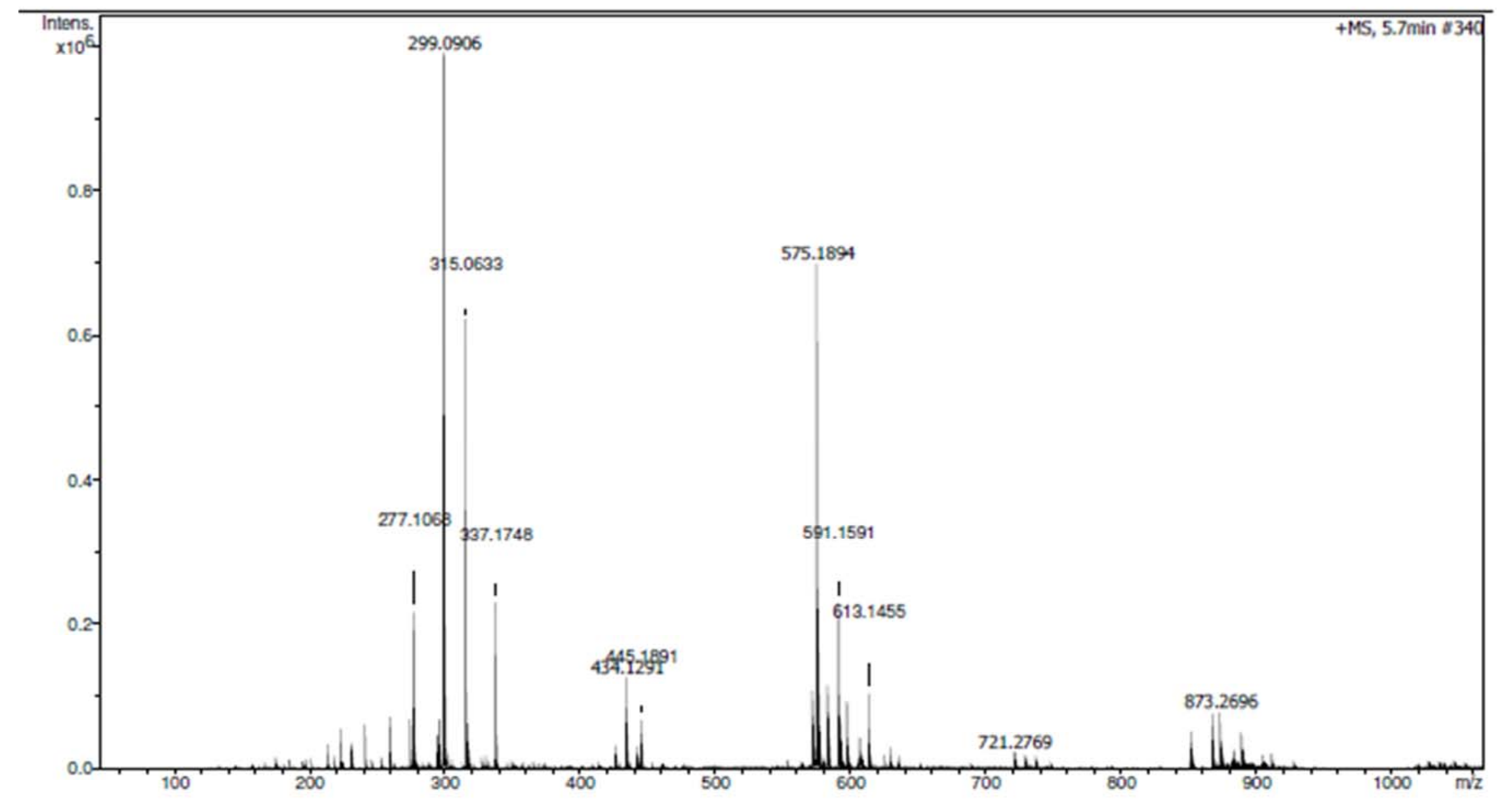

Figura A35. Espectro de massas de alta resolução no modo positivo do metabólito M6 (ESI-TOF; $m / z$ 299,0906 [M+H $\left.{ }_{2} \mathrm{O}+\mathrm{Na}\right]^{+}$) 


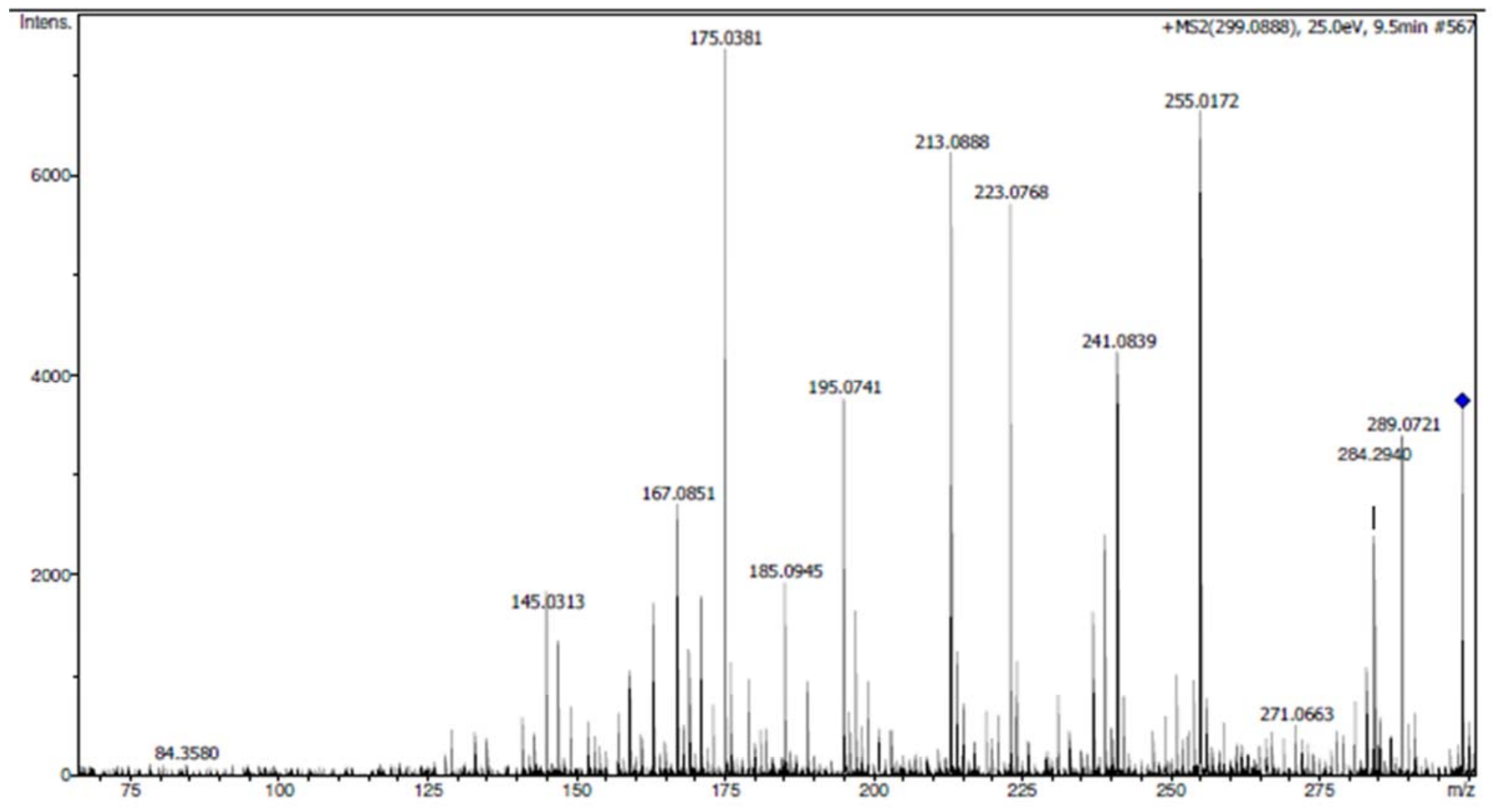

Figura A36. Espectro de EM/EM no modo positivo do metabólito M6 (ESI-MS/MS, 25 eV) 


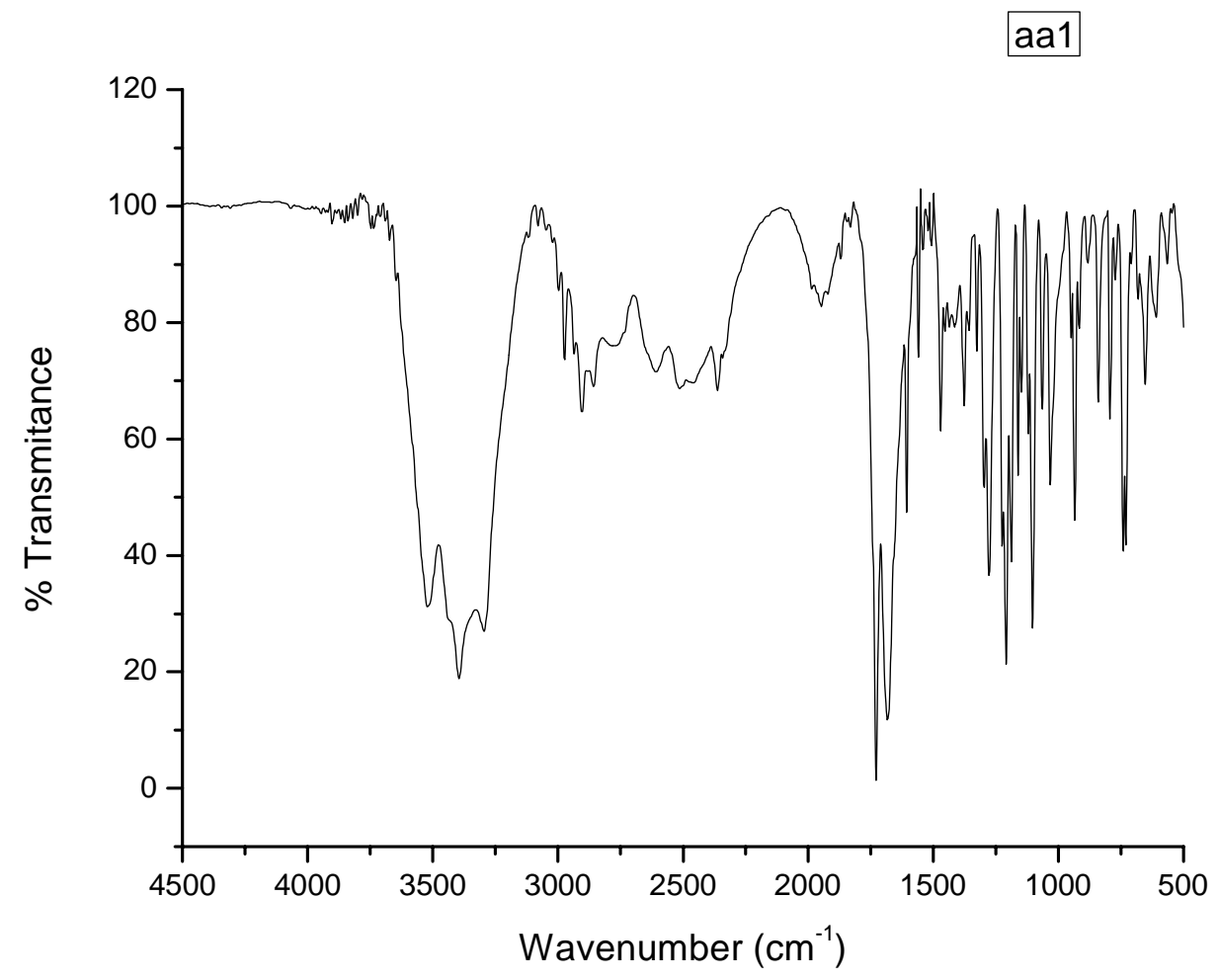

Figura A37. Espectro de infravermelho do metabólito M6 


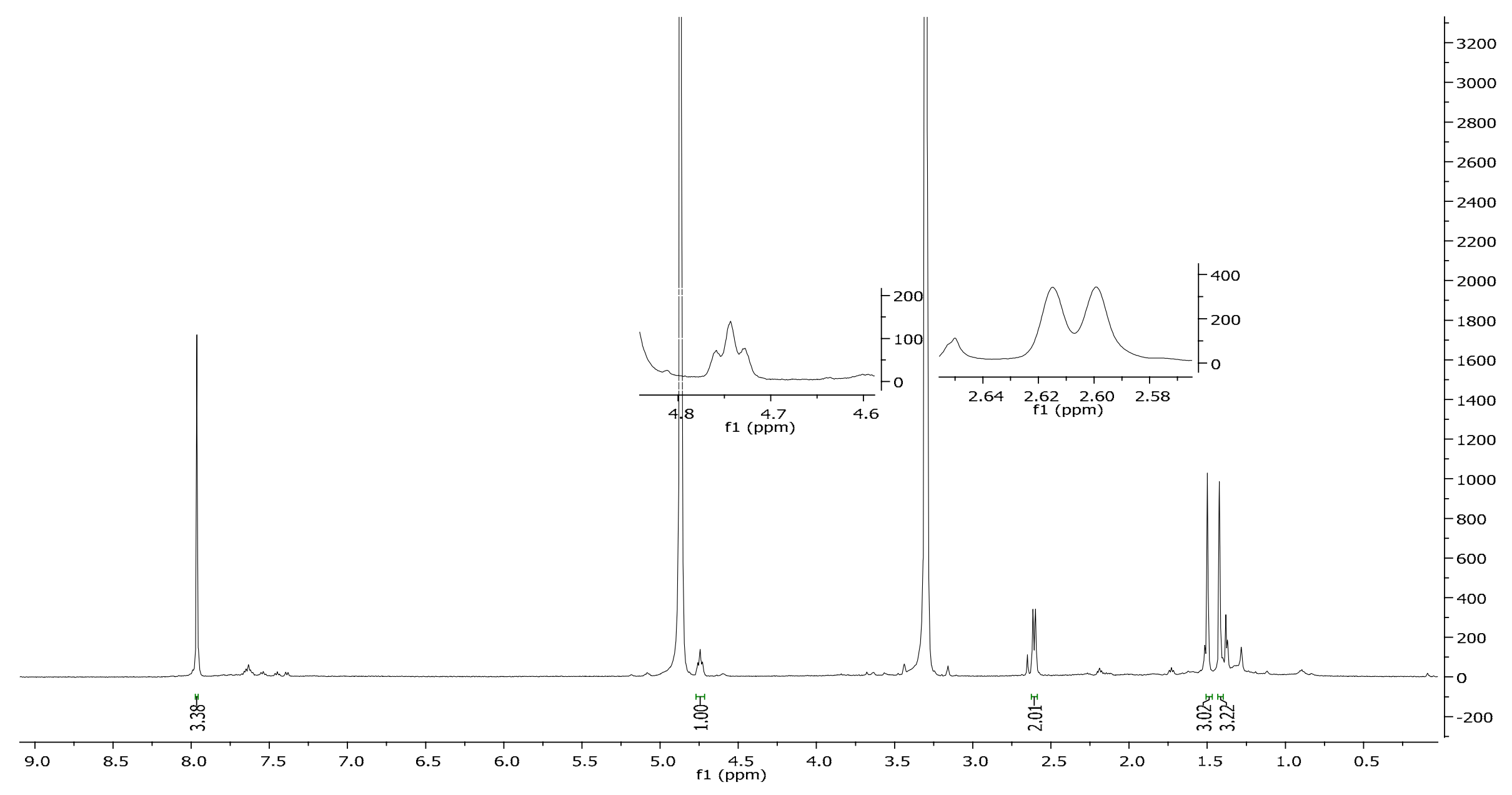

Figura A38. Espectro de $\mathrm{RMN}$ de ${ }^{1} \mathrm{H}$ do metabólito $\mathbf{M} 7\left(500 \mathrm{MHz}, \mathrm{CD}_{3} \mathrm{OD}\right)$ 


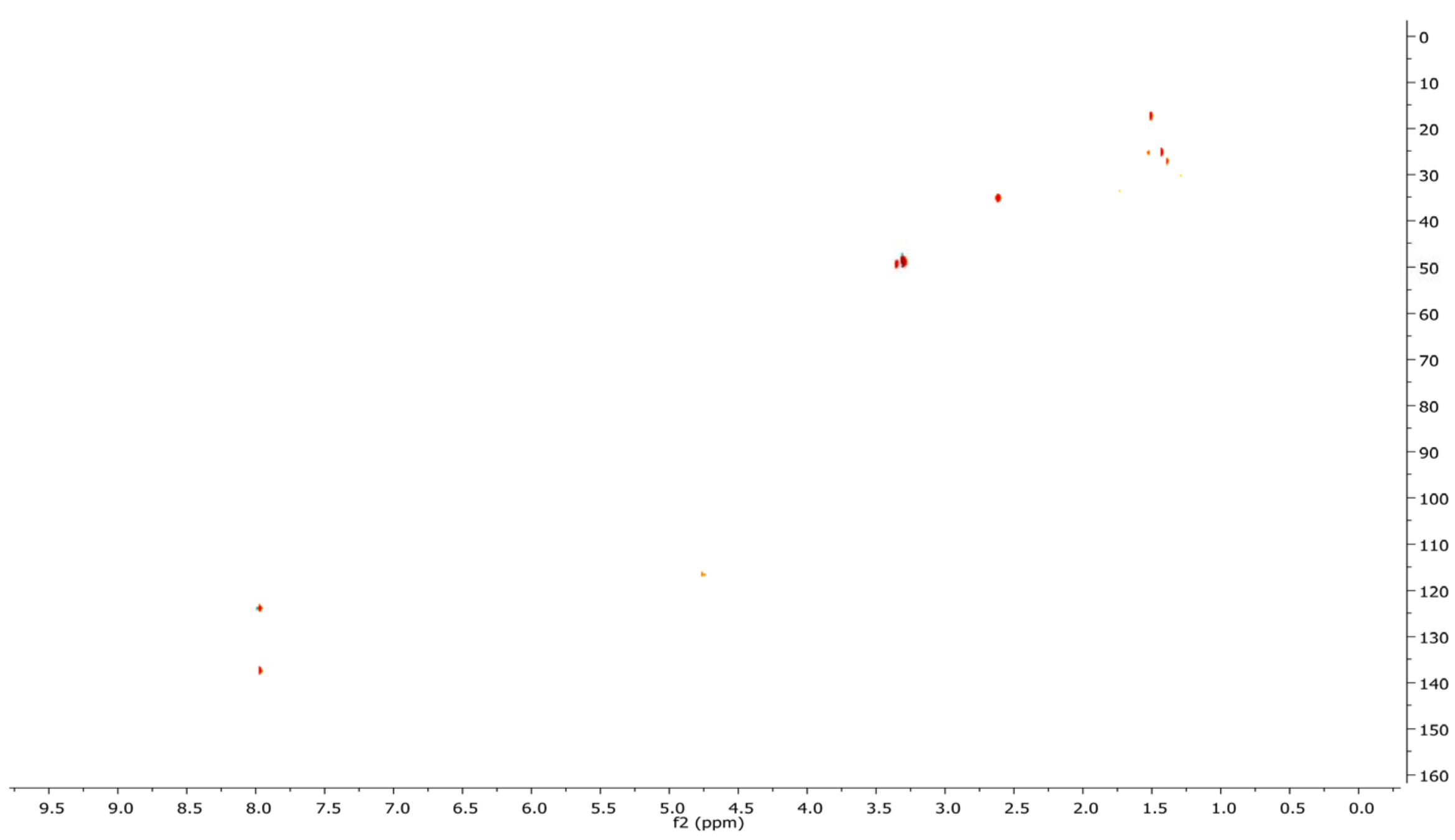

Figura A39. Mapa de contorno de HMQC do metabólito $\mathbf{M} 7\left(500 \mathrm{MHz}, \mathrm{CD}_{3} \mathrm{OD}\right)$ 


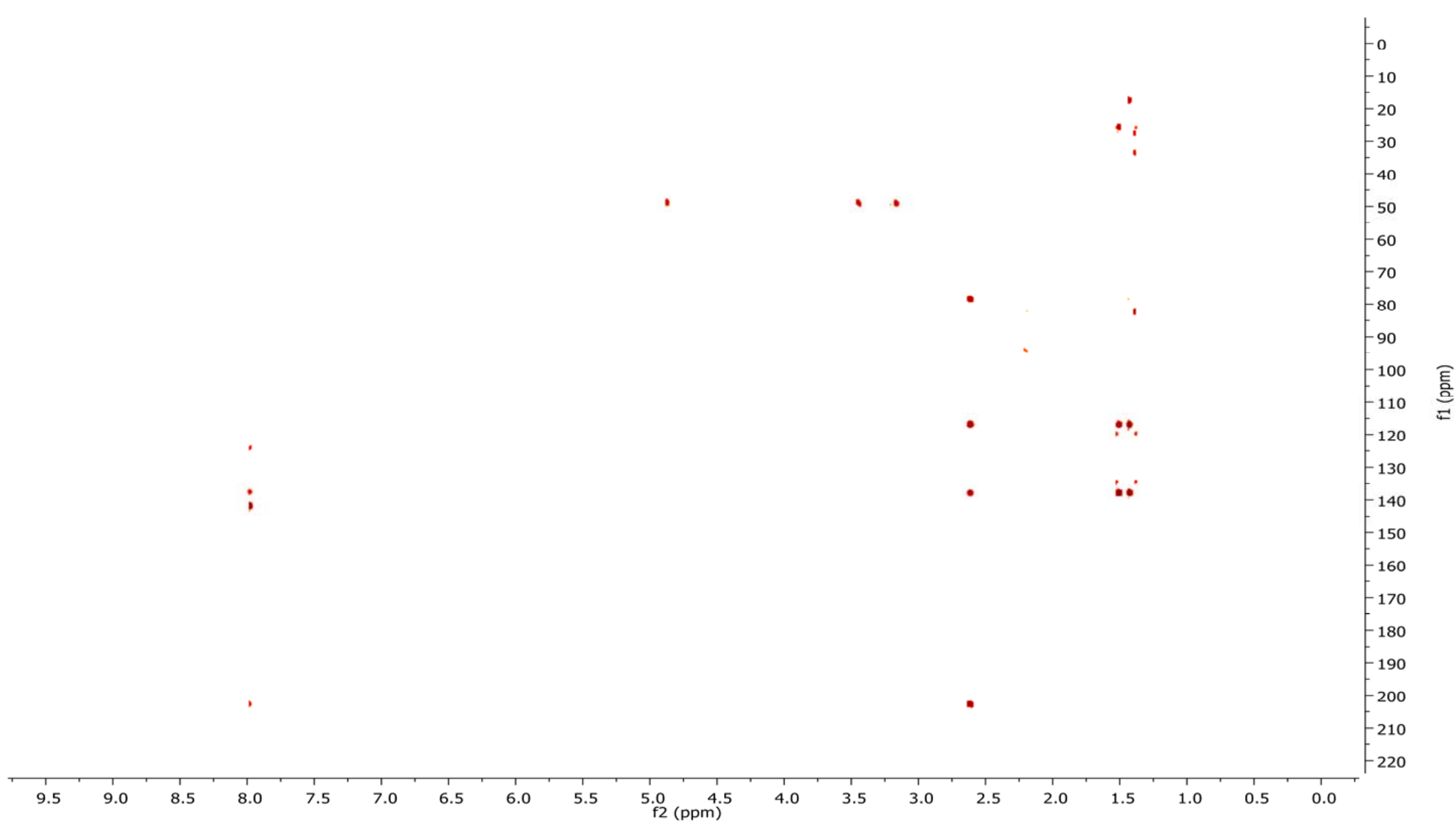

Figura A40. Mapa de contorno de $\mathrm{HMBC}$ do metabólito $\mathbf{M} 7$ (500 MHz, $\mathrm{CD}_{3} \mathrm{OD}$ ) 

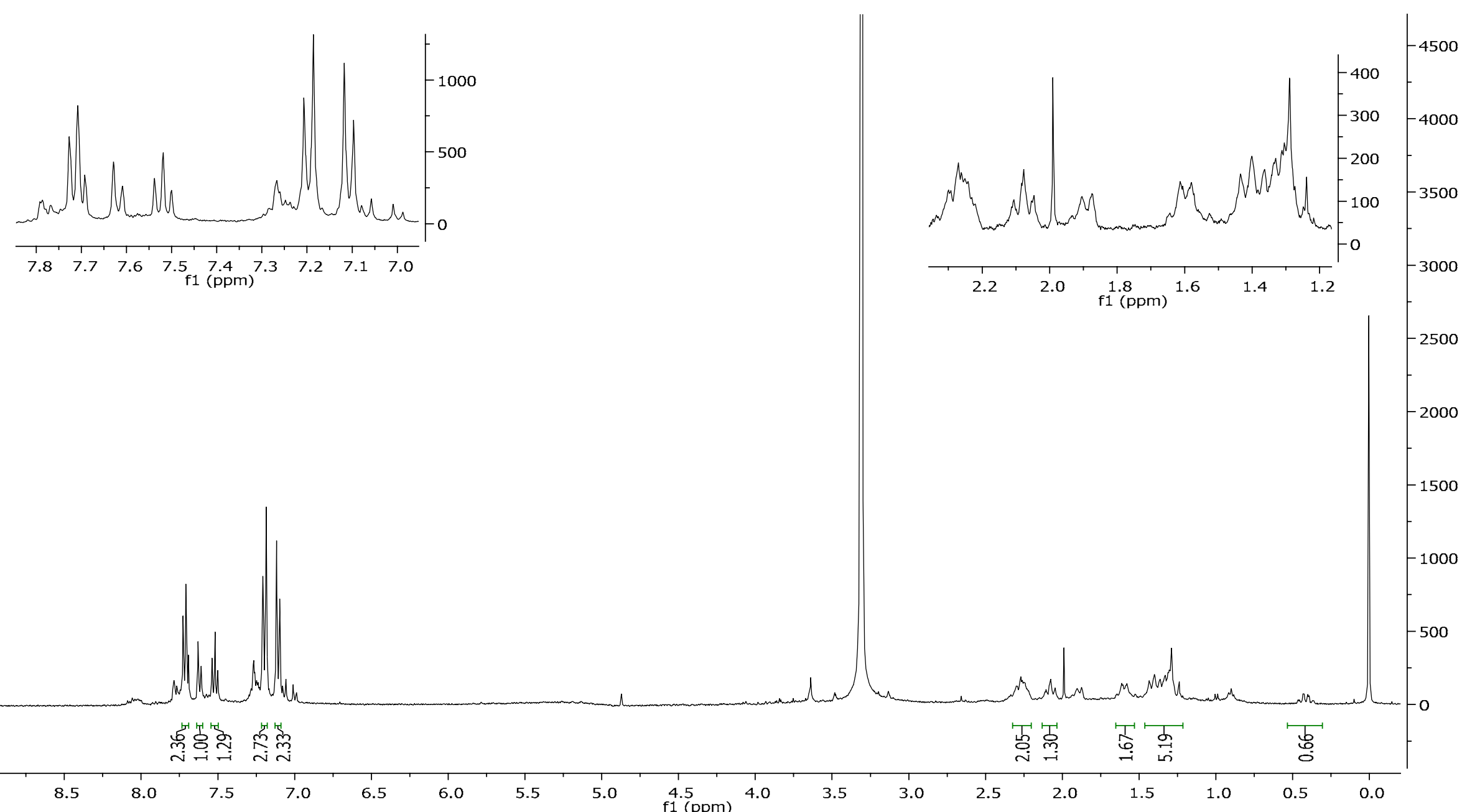

Figura A41. Espectro de $\mathrm{RMN}$ de ${ }^{1} \mathrm{H}$ do metabólito $\mathbf{M 8}\left(500 \mathrm{MHz}, \mathrm{CD}_{3} \mathrm{OD}\right)$ 


\section{Apêndices}

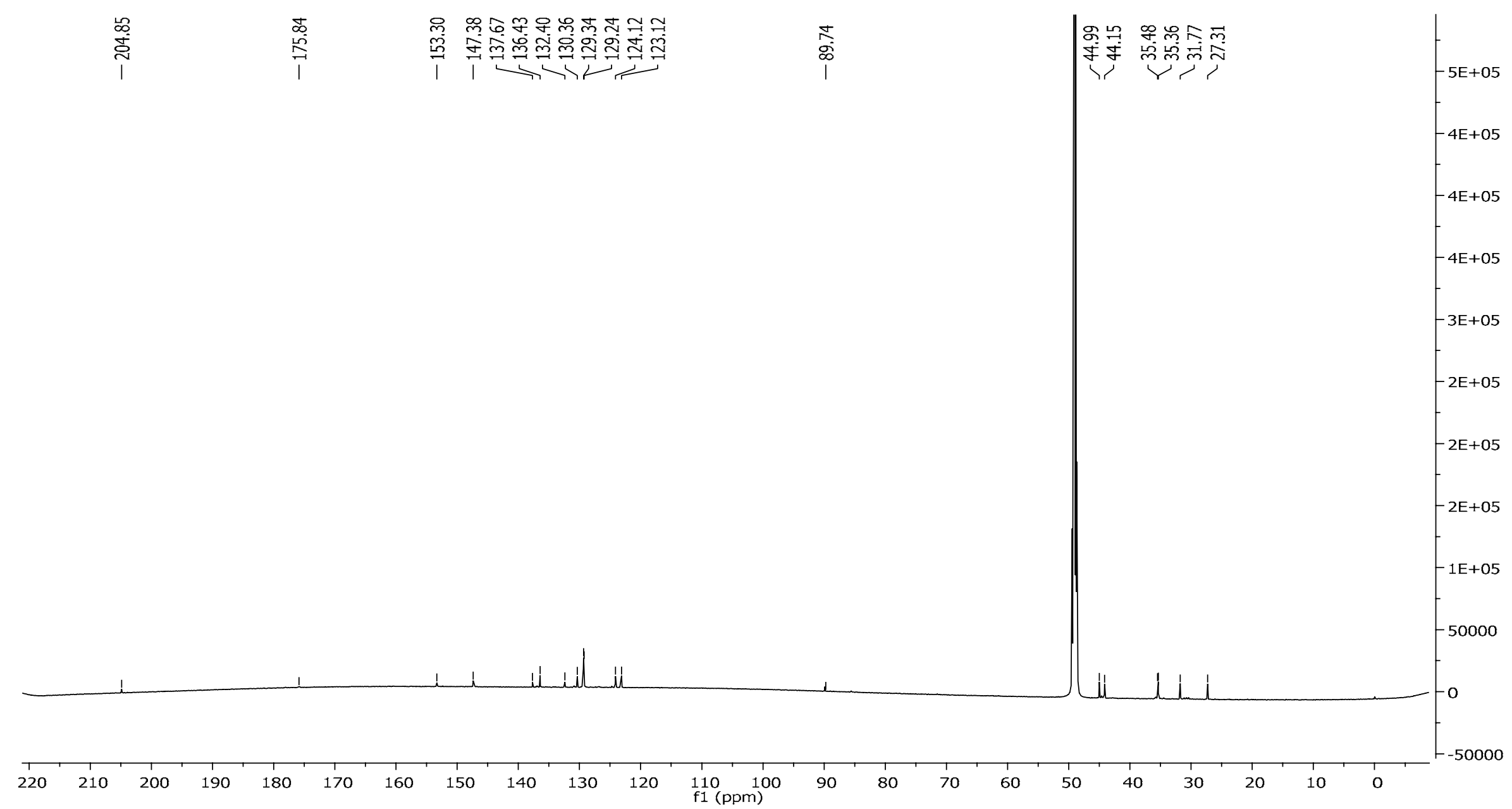

Figura A42. Espectro de $\mathrm{RMN}$ de ${ }^{13} \mathrm{C}$ do metabólito $\mathbf{M 8}\left(500 \mathrm{MHz}, \mathrm{CD}_{3} \mathrm{OD}\right)$ 


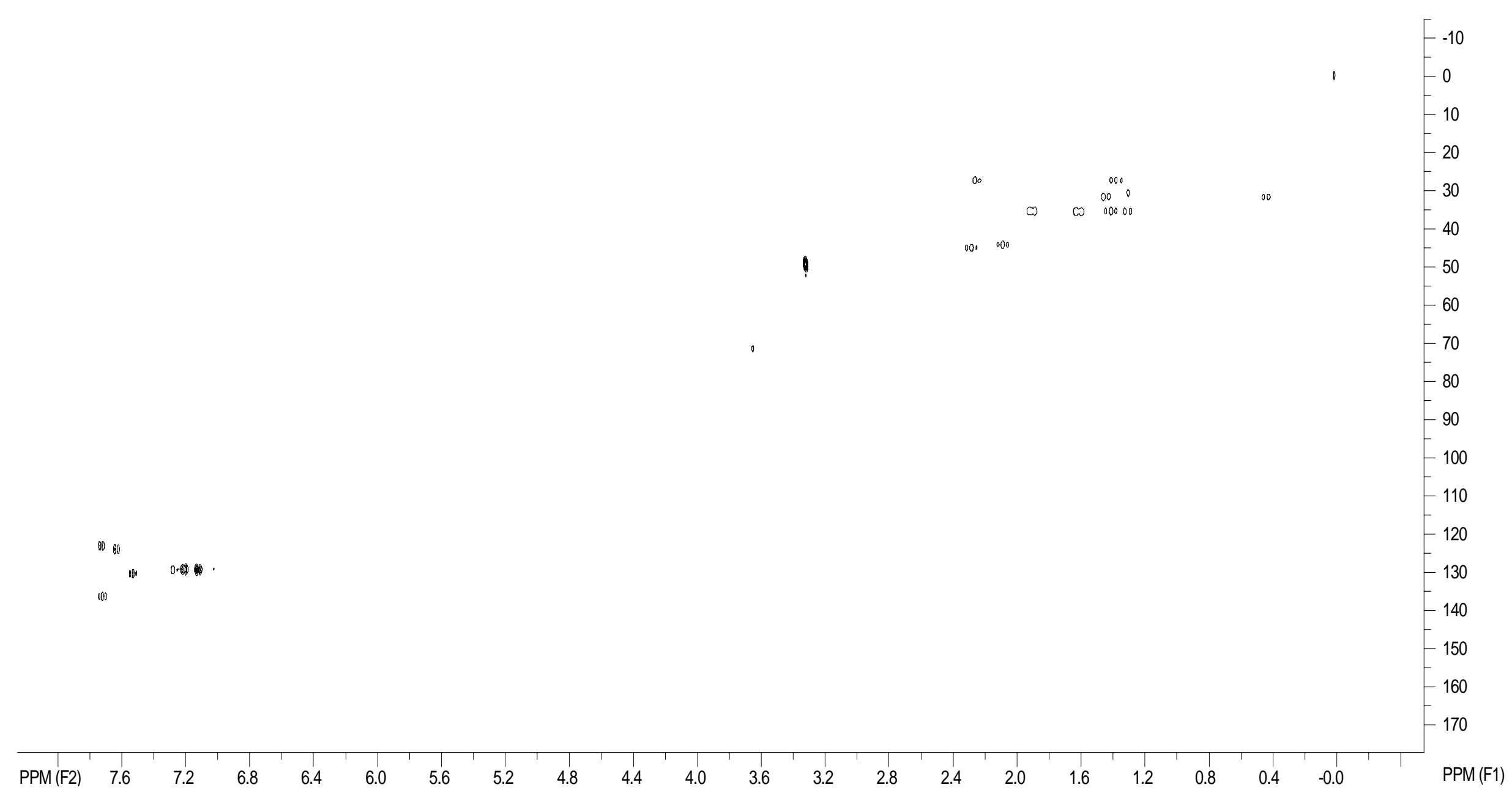

Figura A43. Mapa de contorno de HMQC do metabólito M8 (500 MHz, CD 3 OD) 


\section{Apêndices}

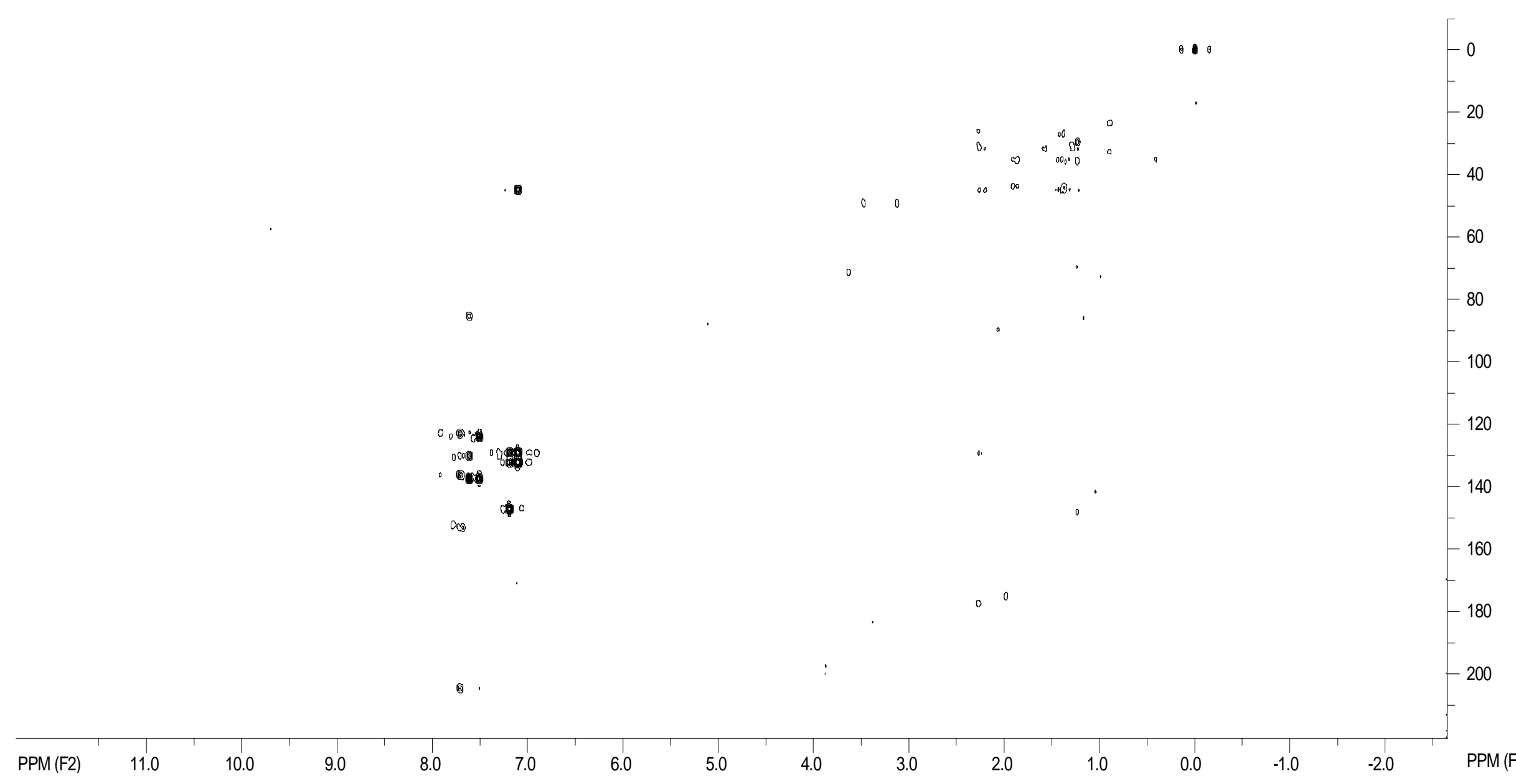

Figura A44. Mapa de contorno de $\mathrm{HMBC}$ do metabólito M8 (500 MHz, $\mathrm{CD}_{3} \mathrm{OD}$ ) 
Apêndices

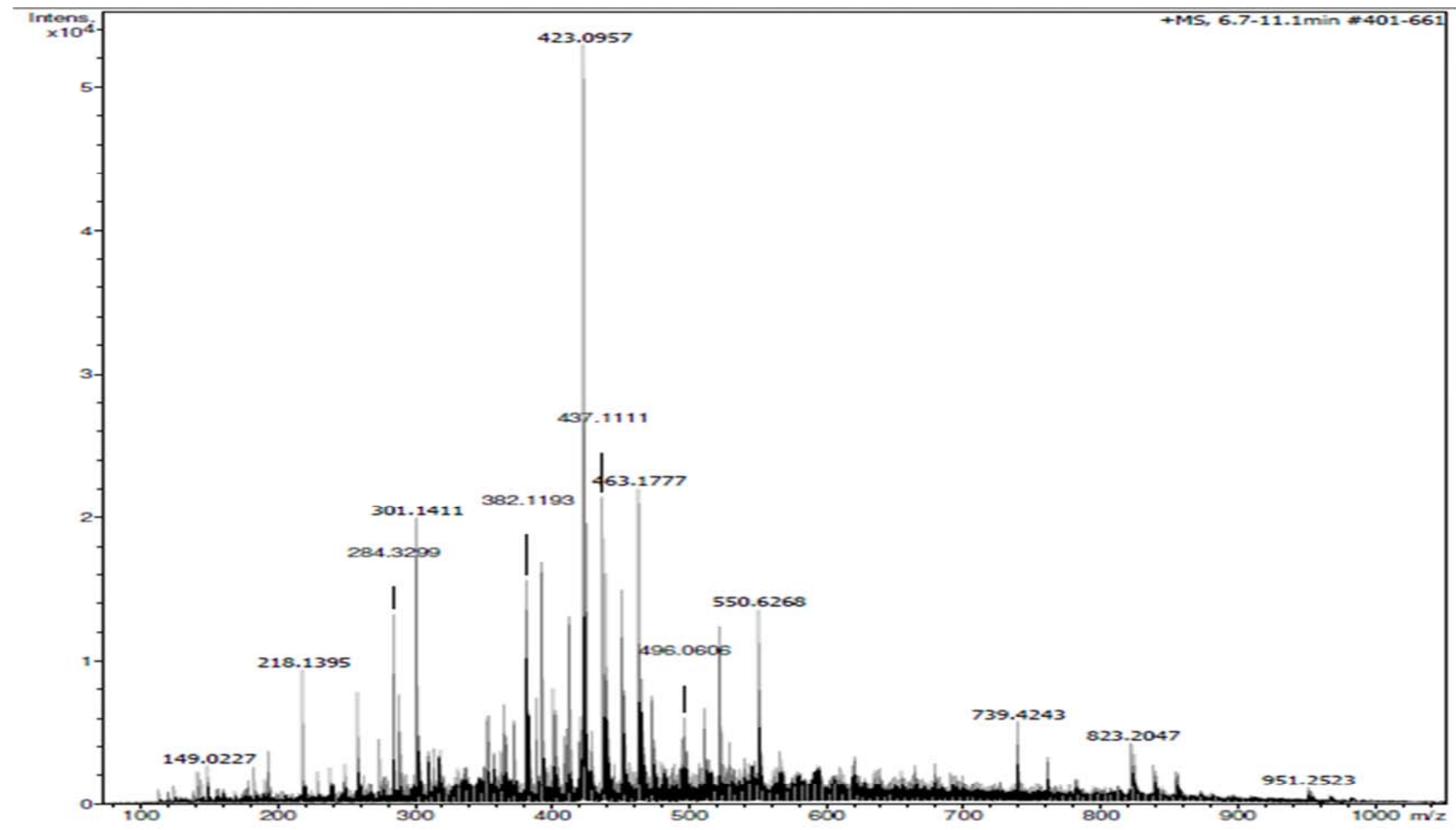

Figura A45. Espectro de massas de alta resolução no modo positivo do metabólito M8 (ESI-TOF; $m / z$ 423,0957 [M+H $\left.\mathrm{H}_{2} \mathrm{O}+\mathrm{Na}\right]^{+}$) 